\title{
THE FORMAL MODELING OF ENGINEERING DESIGN INFORMATION BY MEANS OF AN AXIOMATIC SYSTEM
}

\author{
by
}

Filippo Arnaldo Salustri

A thesis submitted in conformity with the requirements for the Degree of Doctor of Philosophy, Department of Mechanical Engineering, in the University of Toronto

(C)Copyright by Filippo Arnaldo Salustri 1993 
To
Mina 


\section{Abstract}

There is mounting evidence in the current literature which suggests that our collective understanding of engineering design is insufficient to support the continued growth of the engineering endeavor. Design theory is the emergent research field that addresses this problem by seeking to improve our understanding of, and thus our ability to, design. The goal of this author's work is to demonstrate that formal techniques of logic can improve our understanding of design. Specifically, a formal system called the Hybrid Model (HM) is presented; this system is a set-theoretic description of engineering design information that is valid independent of (a) the processes that generate or manipulate the information and (b) the role of the human designer. Because of this, HM is universally applicable to the representation of design-specific information throughout all aspects of the engineering enterprise. The fundamental unit in HM is a design entity, which is defined as a unit of information relevant to a design task. The axioms of HM define the structure of design entities and the explicit means by which they may be rationally organized. HM provides (a) a basis for building taxonomies of design entities, (b) a generalized approach for making statements about design entities independent of how the entities are generated or used, and (c) a formal syntactic notation for the standardization of design entity specification. Furthermore, HM is used as the foundation of DESIGNER, an extension to the Scheme programming language, providing a prototype-based object-oriented system for the static modeling of design information. Objects in the DESIGNER language satisfy the axioms of $\mathrm{HM}$ while providing convenient programming mechanisms to increase usability and efficiency. Several design-specific examples demonstrate the applicability of DESIGNER, and thus of HM as well, to the accurate representation of design information. 


\section{ACKNOWLEDGMENTS}

I would like to thank a number of people who have assisted me in one way or another to complete this work. First, I must thank Dr. R. D. Venter, my advisor and mentor, for his inspiration and guidance. As well, I feel deep gratitude to Drs. B. Benhabib and K. C. Smith who, as members of my Endrenyi Committee, provided valuable feedback and helped me steer clear of sand-traps; and Dr. W. R. Johnson, with whom I began my Doctorate and who introduced me to computer-aided engineering. The assistance of NSERC is also acknowledged with appreciation.

I must also thank my fiancee, Mina, whose patience with me during the last two and a half years has certainly qualified her for sainthood.

Many others - graduate students, professors, and friends - contributed too, professionally and otherwise; to all of them, my sincerest thanks. 


\section{Contents}

$\begin{array}{lll}\text { I INTRODUCTION } & 14\end{array}$

1 Introduction $\quad 15$

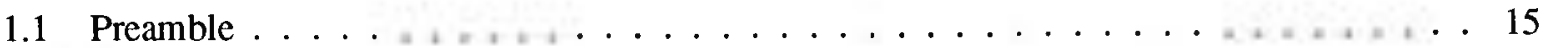

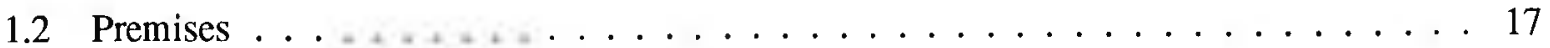

1.3 Statement of Thesis $\ldots \ldots \ldots \ldots \ldots \ldots \ldots$

1.4 General Remarks . . . . . . . . . . . . . . . . . . 20

2 Literature Survey $\quad 23$

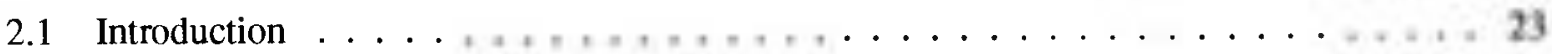

2.2 Design Theory . . . . . . . . . . . . . . . . . . 24

2.3 Computer-Aided Engineering . . . . . . . . . . . . . . . . . . 29

2.4 Cognitive and Concurrent Design Research $\ldots \ldots \ldots \ldots$

2.4 .1 Cognitive Design Research . . . . . . . . . . . . . . . . . 33

2.4 .2 Concurrent Engineering . . . . . . . . . . . . . . . . 34

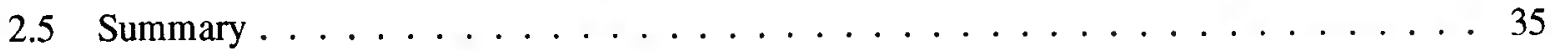

II THE ROLE OF LOGIC IN DESIGN

3 Introduction $\quad 38$

4 Motivating Discussion 41

4.1 Terminologic Considerations . . . . . . . . . . . . . . . . . 41

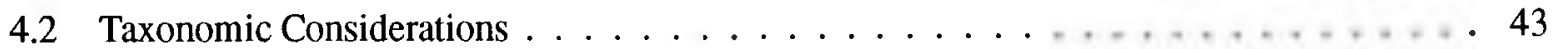

4.3 Computational Considerations . . . . . . . . . . . . . . . 44 


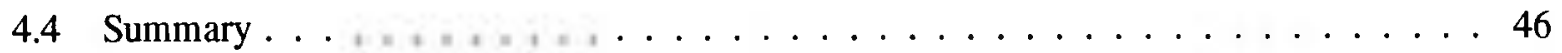

5 A New View of Design $\quad 48$

5.1 The Notion of Self-Reference $\ldots \ldots \ldots \ldots \ldots$

5.2 Design as an "Artificial" Science . . . . . . . . . . . . . . . 50

5.2 .1 The Scientific Approach . . . . . . . . . . . . . . . . . . 50

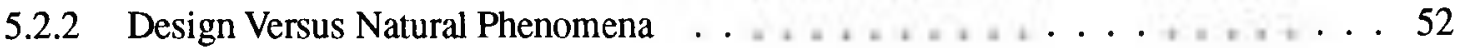

5.2 .3 The Role of Design Theory $\ldots \ldots \ldots \ldots$

$5.3 \quad$ Summary . . . . . . . . . . . . . . . . . . . . . 55

6 Logical Solutions $\quad 56$

6.1 Limiting Self-Reference in Design . . . . . . . . . . . . . . . . . . 56

6.2 Categorization of Design Aspects $\ldots \ldots \ldots \ldots \ldots$

6.2 .1 Artifact Modeling . . . . . . . . . . . . . . . . . . . 60

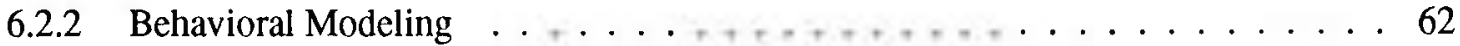

6.2 .3 Design Evolution, or Meta-Modeling $\ldots \ldots \ldots \ldots \ldots \ldots \ldots$

6.2 .4 Implementations . . . . . . . . . . . . . . . 63

6.2 .5 The Example, Revisited . . . . . . . . . . . . . . . . . 63

6.2 .6 Relationship to the Layered Structure $\ldots \ldots \ldots \ldots \ldots \ldots \ldots . \ldots \ldots$

6.3 Summary . . . . . . . . . . . . . . . . . . . . 64

$\begin{array}{llr}7 & \text { Discussion } & 65\end{array}$

$\begin{array}{lll}\text { III FORMALIZING DESIGN INFORMATION } & 67\end{array}$

8 Introduction $\quad 68$

8.1 Modeling the Design Process $\ldots \ldots \ldots \ldots$

8.2 Basic Structures and Concepts . . . . . . . . . . . . . . . 72

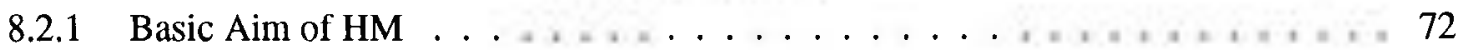

8.2.1.1 A Prescriptive, Axiomatic Approach . . . . . . . . . 72

8.2.1.2 Universe of Discourse and Design Entities . . . . . . . . . . 74

8.2.2 Theory of Logical Types and Set Theory $\ldots \ldots \ldots \ldots$ 
8.2.3 Fundamental Structures and Isomorphisms $\ldots \ldots \ldots \ldots \ldots$

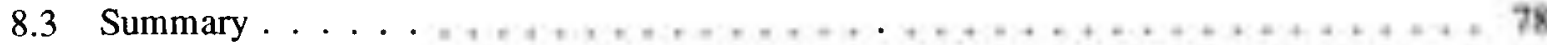

9 The Structure of Objects $\quad 79$

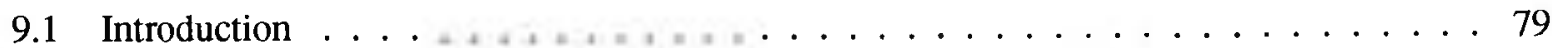

9.2 Definition of Objects . . . . . . . . . . . . . . . . . . . . . . . 79

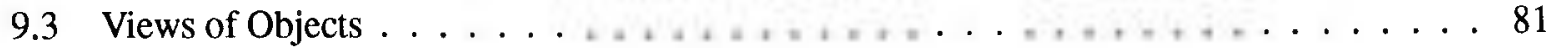

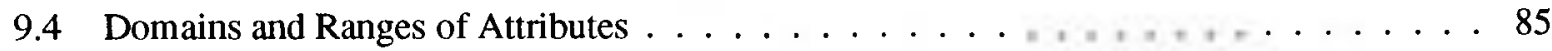

9.4.1 Set Theoretic Foundations . . . . . . . . . . . . . . . . . . 85

9.4 .2 Domains and Ranges in $\mathrm{HM} \ldots \ldots \ldots \ldots \ldots \ldots$

9.5 Dimensions of Measurement . . . . . . . . . . . . . . . . . . . . . 87

9.6 Constraints and Attributes $\ldots \ldots \ldots \ldots$

9.7 Summary . . . . . . . . . . . . . . . . . . . . . . . . . . . 89

10 Ordering Mechanisms for Design Information 90

10.1 Introduction . . . . . . . . . . . . . . . . . . . . . 90

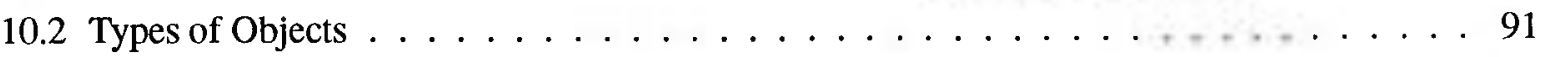

10.3 Aggregations of Objects . . . . . . . . . . . . . . . . . 95

10.4 Classes of Objects . . . . . . . . . . . . . . . . . . . . . . . . . . . . . 99

10.5 Specialization and Generalization of Objects $\ldots \ldots \ldots$. . . . . . . . 100

10.5.1 Specialization of Types . . . . . . . . . . . . . . . . . . 100

10.5 .2 Generalization of Types $\ldots \ldots \ldots \ldots \ldots$. . . . . . . . . . . 102

10.5.3 Relationship Between Specialization and Views . . . . . . . . . . . 103

10.6 Summary . . . . . . . . . . . . . . . . . . . . . . . . 103

11 Discussion $\quad 104$

11.1 General Summary . . . . . . . . . . . . . . . . . . . . . . . . 104

11.2 Future Work . . . . . . . . . . . . . . . . . . . . . . 105

$\begin{array}{lr}\text { IV ENGINEERING COMPUTATION } & 107\end{array}$

12 Introduction 108 
13 Requirements for a New Programming Paradigm 113

13.1 Functional Programming . . . . . . . . . . . . . . . 114

13.2 Semantic Data Modeling . . . . . . . . . . . . . . . . 116

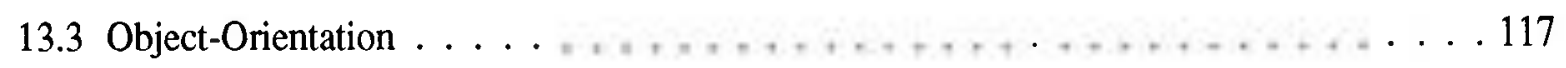

13.3.1 Message Passing Protocols $\ldots \ldots \ldots \ldots \ldots \ldots \ldots \ldots$

13.3.2 Abstraction Mechanisms . . . . . . . . . . . . . . . 120

13.3.3 Hierarchical Construction of Objects . . . . . . . . . . . . . 121

13.4 Combining Object-Orientation and Functional Programming $\ldots \ldots \ldots \ldots$

13.5 Summary . . . . . . . . . . . . . . . . . . . . . 123

14 Concepts and Forms in Designer $\quad 124$

14.1 Syntactic Conventions . . . . . . . . . . . . . . . . . . . . 125

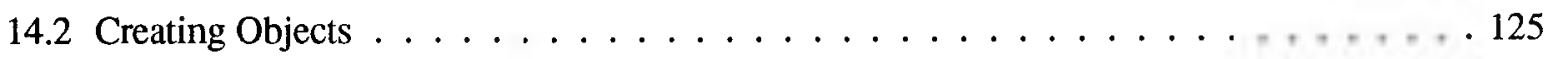

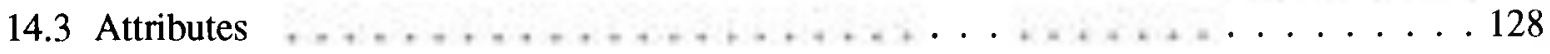

14.4 Constraints between Attributes . . . . . . . . . . . . . . . . . 129

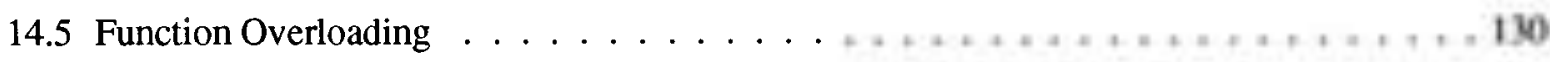

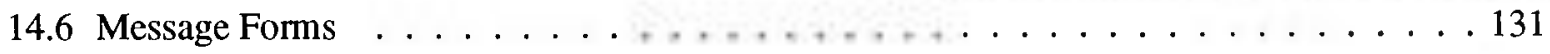

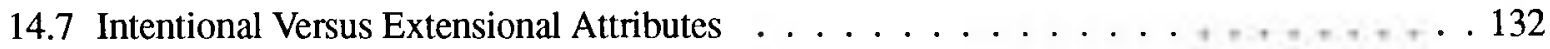

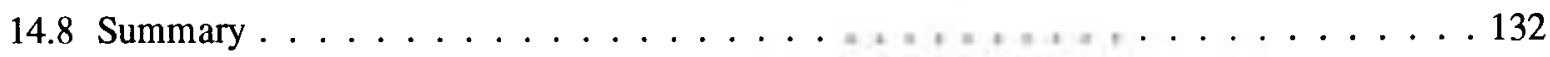

15 Examples $\quad 134$

15.1 Simple Examples . . . . . . . . . . . . . . . . . . . . . . 134

15.2 Multiple Inheritance . . . . . . . . . . . . . . . . . . 138

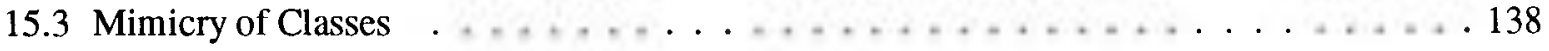

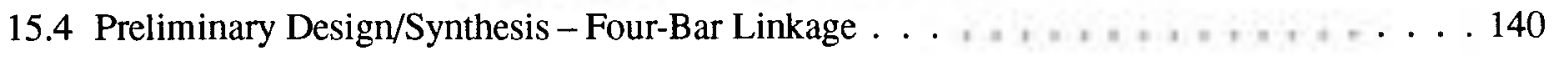

15.5 Hierarchical Organization - Thermal Analysis of a Wall . . . . . . . . . . 146

15.5.1 Structural Modeling Considerations . . . . . . . . . . . . . . 148

15.5.2 Thermal Analysis Modeling Considerations . . . . . . . . . . . . . 148

15.5.3 Definition of Wall Prototype Objects $\ldots \ldots \ldots 149$

15.5.4 Example of Wall Model Usage . . . . . . . . . . . . . . . . . . 154

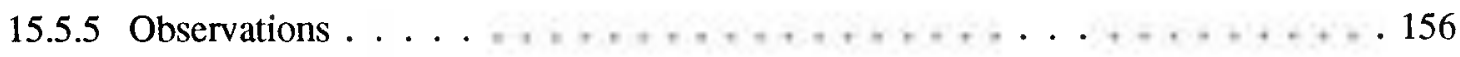


V CONCLUSION

17 Final Discussion

18 Future Directions

19 Closing Remarks

VI APPENDICES

A Source Listings of Designer

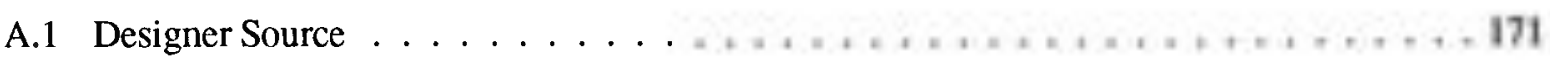

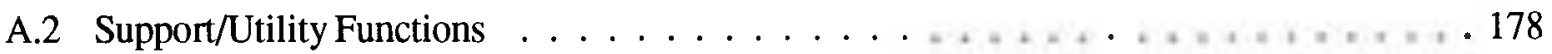

B Designer Prototype Library $\quad 181$

B.1 Complex Numbers . . . . . . . . . . . . . . . . 181

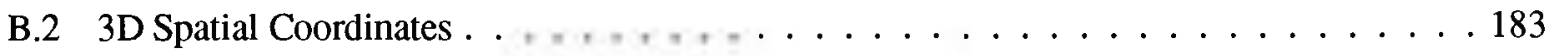

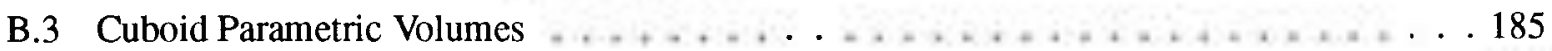

B.4 Coordinate Frames $\ldots \ldots \ldots \ldots \ldots \ldots$

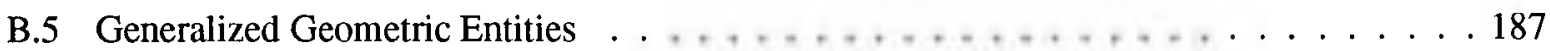

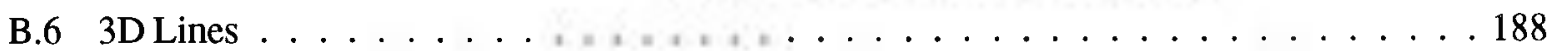

B.7 Generalized Physical Parts . . . . . . . . . . . . . . . . . . . . . 189

B.8 Queues . . . . . . . . . . . . . . . . . . . . . . 190

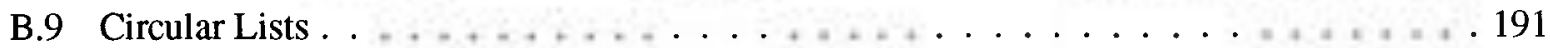

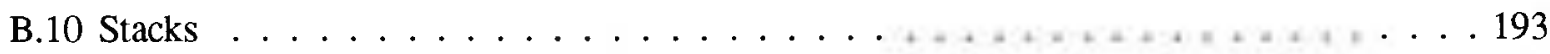

B.11 Geometric Transforms . . . . . . . . . . . . . . . . . . . . 194 


\section{List of Figures}

5.1 Relationship between design theory and science. $\ldots \ldots \ldots \ldots \ldots$

6.1 Logical structure for removal of self-reference . . . . . . . . . . . . . . . 57

6.2 Graphical representation of the 4D Design Space as two 3D spaces . . . . . . . . 61

10.1 Aggregation of a Four-Bar Linkage in HM. . . . . . . . . . . . . . . . . 98

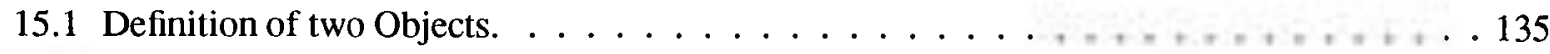

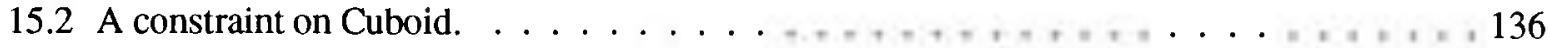

15.3 Example of constraint on intentional attributes. . . . . . . 136

15.4 Examples of DESIGNER queries and messages. $\ldots \ldots \ldots \ldots \ldots \ldots \ldots \ldots$

15.5 An example of multiple inheritance in DESIGNER. . . . . . . . . . . . . . . 139

15.6 Example of use of DESIGNER Class object. . . . . . . . . . . . . . . . . 140

15.7 Schematic geometry of 4 bar and Link objects. . . . . . . . . . . . . . . . 141

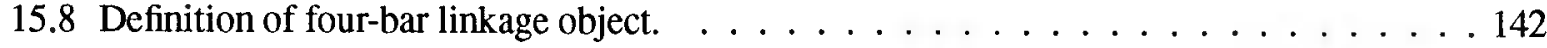

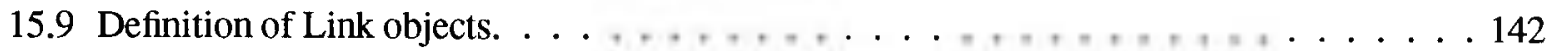

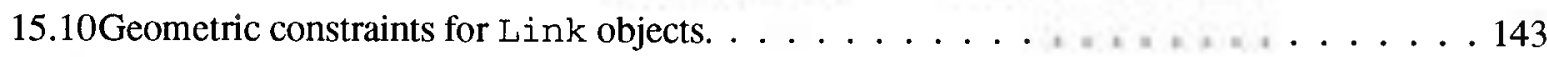

15.11 Three point synthesis method. . . . . . . . . . . . . . . . . . . 144

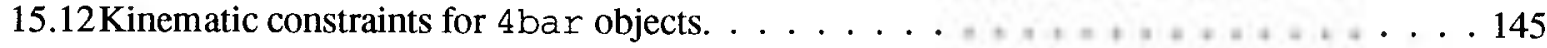

15.13 Inheritance/Aggregation Network for Wall Example. . . . . . . . . . . . . . 147

15.142D Shape objects. . . . . . . . . . . . . . . . . . . 149

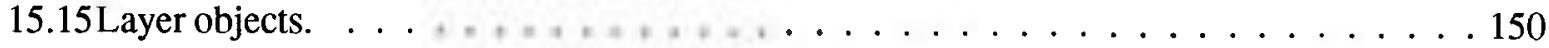

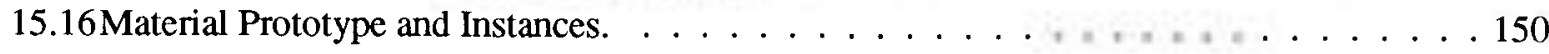

15.17 Atomic wall components for openings and segments. . . . . . . . . . . . . 151

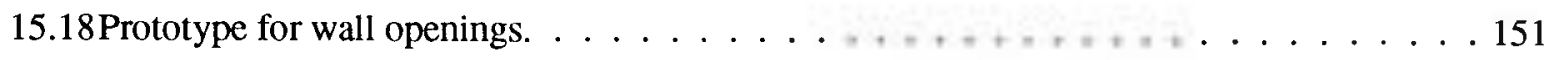




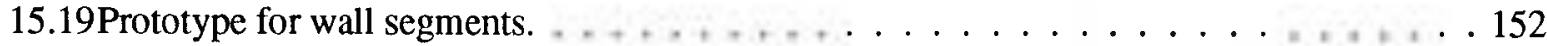

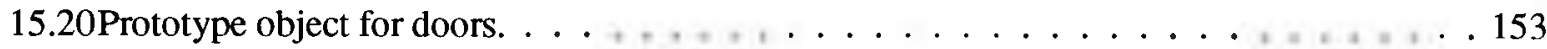

15.21 Prototype objects for windows. $\ldots \ldots \ldots \ldots \ldots$

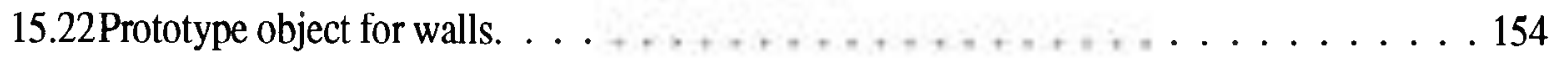

15.23 Two sample wall segments. . . . . . . . . . . . . . . . . . 155

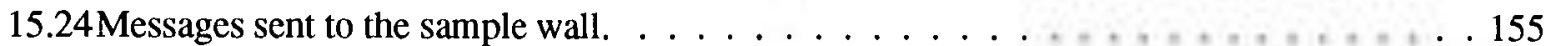

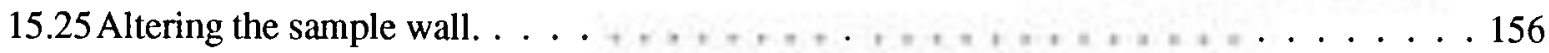




\section{List of Symbols}

The notation presented in this section is drawn from accepted systems of notation in predicate calculus and axiomatic set theory. In addition, a number of symbols used exclusively by the author for the Hybrid Model (Part III) are also included. Usage of these symbols is restricted to Part III, wherein the formal statement of the Hybrid Model in the language of mathematical logic is presented.

Basic logic and set theoretic symbols are:

$\epsilon$

Set membership; for example, $x \in I$ is read " $x$ is a member of $I$ ". This is taken to be primitive to the 1 st order predicate calculus and so is considered an undefined primitive in axiomatic set theory.

$=\quad$ The identity operator, which is transitive $(x)(y)(((x=y) \cap(y=z)) \Rightarrow(x=z))$, symmetrical $(x)(y)((x=y) \Rightarrow(y=x))$ and totally reflexive $(x)(x=x)$. For example, $x=y$ iff every attribute of $x$ is an attribute of $y$, and conversely. This is taken to be primitive to the 1 st order predicate calculus and so is considered an undefined primitive in axiomatic set theory.

$=\quad$ Read as "... define as...", this symbol is used to introduce definitions (e.g. $X=_{d f}\{x:$ $(x \in Y) \bullet(x \in Z)\}$, which defines $X$ to be the set of elements occurring in both $Y$ and $Z$ ) and is distinct from the identity operator (above).

$\subset \quad$ Subset relationship; for example, $x \subset y$ is read " $x$ is a subset of $y$ ".

$\forall \quad$ The universal qualifier, read as "for all ...". Statements using $\forall$ are composed of three parts: the $\forall$ symbol, the specification of a variable or variables over which the 
quantification is performed, and a statement which is true for the variable(s). The parts are separated by parentheses. For example, $\forall(x)(x \in I)$ is read "for all $x, x$ is a member of $I^{\prime \prime}$. Also, if $I$ is the set of all integers, $\forall(x \in I)(x>0)$ defines all positive integers, and is read "for all $x$ in $I, x$ is greater than 0 ".

The existential qualifier, read as "there exists...". Statements using $\exists$ have the same form as statements using the universal quantifier. For example, $\exists(x \in I)(x=1)$ is read as "there exists an $x$ in $I$, such that $x$ equals 1 ". It is generally unclear whether this qualifier should be read as "there exists at least one $x$ in $I$..." or as "there exists exactly one $x$ in $I \ldots$... A distinction is made in [1] between the two by using $! \exists$ to indicate the latter and $\exists$ for the former. We adopt this distinction here because the semantic difference is relevant to the development of the Hybrid Model. Logical equivalence. This rule of inference is defined by the statement $(x \equiv y) \equiv(x \Rightarrow$ $y) \cap(y \Rightarrow x)$.

Logical not operator, read as "...not...", and resulting in the logical negation of its immediate consequent. For example, if $x$ is true, then $\neg x$ is false.

ก Intersection operator, read as “...and...”. The result of this operation is the set intersection of its antecedent and consequent. For example, $x \cap y$ results in the intersection of the set entities $x$ and $y$. This form is used exclusively for set operations. Also, the form $\bigcap_{i} X_{i}$ means the intersection of all $X_{i}$.

- $\quad$ Boolean "and" operator. The result of this operation is true iff both its antecedent and consequent are true. For example $p \bullet q$ is true iff both statements $p$ and $q$ are true.

U Inclusive union operator, read as “...or...”. The result of this operation is the set union of its antecedent and consequent. For example, $x \cup y$ is the set containing all the members of both set $x$ and set $y$. Also, the form $\bigcup_{i} X_{i}$ means the union of all $X_{i}$.

The boolean inclusive "or" operator. The result of this operation is true iff either or both of its antecedent and consequent are true. For example, $p+q$ is true iff (a) $p$ is true, or (b) $q$ is true, or (c) $p$ and $q$ are true. The exclusive union operator (i.e. the operator 
the result of which is true if only one but not both of $p$ or $q$ is true) is defined by the expression $(p+q) \bullet \neg(p \bullet q)$.

$\Rightarrow \quad$ Material implication, read as “...implies...". Classically, this is the only kind of implication used in formal logic. The antecedent of $\Rightarrow$ implies the consequent; that is, if the antecedent is true, then the consequent is also true. This operator is used when only the truth value of the antecedent is known and the value of the consequent is unknown.

$\langle\ldots\rangle \quad$ Angle brackets denote tuples, which are short ordered lists treated as single units. For example, $\forall(\langle x, y\rangle)((x \in I) \bullet(y \in I))$ denotes an ordered pair of integers.

$\supset \quad$ Superset operator. Equivalent to $\Rightarrow$.

$\supseteq \quad$ Superset-or-equality operator.

$\emptyset \quad$ The empty (or null) set.

$\mathcal{P}(X) \quad$ The power set of $X$; i.e. the set containing all subsets of $X$ (including the empty set).

A function is denoted by its name followed by arguments. The arguments are in parentheses. For example, $\operatorname{VIEW}(X, \varphi)$ is a function whose name is VIEW, and whose arguments (in this case) are $X$ and $\varphi$. Functions may have no arguments. A function with one argument is called a unary function; a function with two arguments is called a binary function; a function with more than two arguments is called an $n$-ary function. A function returns some data entity. In general, a function is written $f(x)$.

Function variables (i.e. variables that represent functions) are written in greek characters, for example $\varphi$. A predicate is like a function, but it can only return one of two values, true or false.

The following symbols are used exclusively in the Hybrid Model.

$\begin{array}{ll}X, Y, Z & \text { individual objects. } \\ C_{i} & \text { A collection } i \text { of objects. } \\ a, b, c & \text { attributes of objects. } \\ 0 & \text { The set of all objects. }\end{array}$


The set of all object types.

$T, U, V \quad$ types.

C The set of all classes of objects.

A The set of all attributes.

D The set of all attribute domains.

R The set of all attribute ranges.

$\Gamma \quad$ The set of all view definitions.

$\gamma$

A view definition.

IS_A The typing predicate, read as “...is a..." and used to relate objects to types. For example: IS_A $(X, T)$ is true if object $X$ is of type $T$, and false otherwise.

INHERITS The inheritance predicate, read as “. . . inherits from..." and used to relate object types. For example: INHERITS $(T, U)$ is true if type $T$ inherits from (i.e. is specialized from) type $U$ or, similarly, if type $U$ is inherited by (i.e. is generalized from) type $T$.

$\Delta \quad$ The set of all aggregate predicates.

$\delta$

An aggregate predicate. 


\section{Glossary}

This glossary contains serms relevant to the wok presenbod berein that abe nee ecmmonly used in enginoerine, but that are quile common in other field. For each tem in the gloosang the poge where the term is fins esed is given in parentheses.

Abstraction Mechanism. A device of Acctaique whereby details afe temoved from some collectioe of infomation leaving only that which is censidered essential. Abciraction mechaniseas permit the ondering er erganiratice, of information. (page 19)

Cartesian Produst: The cartesian pooduct of two sets $A$ and $B$ is defined as the set of entened pairs such the the first element of evtry otbend pair is a merslber of $A$ and the socood element of every enternd pair is a member of $B$, (ruge S5)

Completeness: The property of a formal sysuen wherein exactly all true stanemeats can be proven true and exactly alt false statemenss can be proves false. (page 45)

Condistency: In logic, the state of a formal systen containing no coetrafictions, that is, a formal system is consistert if all wions and theortms in the system are valid (see below) with respect to each other, (page 43)

Design Emtity: A ueit, not nocessanily reallirable in and of itself, of relevance in design; an ieformation model of real world structures of we ita a design process, but noe inclading the design process itself. (rage 74)

Dynamic Data Modeling: The modeling of scrnantic propenties and the enxipolation of dasa stoctures. ofien in refierence to database transactions. (poge 157) 
Fncapualation: The discretization of a quartity of infoemation into a meaningful sinucture that can be treaied as a single unit. (page 76)

Fpistemolery: The stufy of a theory of the narare and groends of knowlodge, especially with reference to its limits and validicy'. (page 81)

Formal System: A system consisting of a set axions taken as peenises, and a set of rules by which theoeens nary be proven by application of the axions, Groge 19 )

Heuristic: Something valuable foe enpirical restanch but unpooved of incapable of proof. (pape 34)

Inmorphism: In lopic, the relasionship betwocn a formal systes and some perceived aspect of reality.

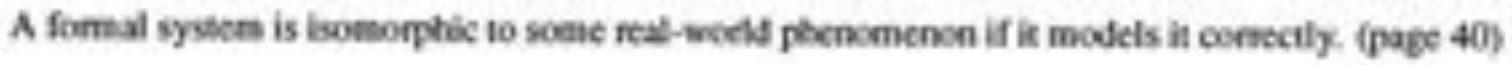

Ontology: A branch of metaptryics relating to the nabure of being; a particular theory about the nature ef being of the kinds of exidtence? (jage 90 )

Paradox: In logics a statcment that can be proven both true and false in a given formal sysuem. (fouge 45)

Static Data Modeling: The sescriptionef data objocts and their nelationships withoes coevidering of tho operations in which such structeres may be usod. (page 111)

Universe of Discourse: The domain about which all intededing argements are ande. For example, is set thoory, the universe of discoune is that of all sets. (page 74)

Validity: In logic, the state of being true under any interpetation, that is, a statement or formola is valid if it can never be fatse. (page 3s)

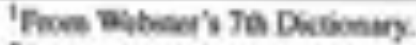

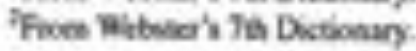




\section{Part I}

\section{INTRODUCTION}




\section{Chapter 1}

\section{Introduction}

\subsection{Preamble}

What is enginetring design?

In the brodest sense, the issue addresuod by this work is that hamanity lacks a suffolient undersanding of the process of engineering design. Althougl simple cnowgh to phrise, this problem has been an issue of contertion for years, and the soetcimes very emoeional arzunents made by various proponenss of ene viewpoine of ancether, methodology A or B, systen $X$ of $Y$, have possibly done alofe harm than good. It has always sinuck, this author as highly suspicious behrvior when ene is unuble wo sefrain from oven generalization and enotional thewoke to cotvince an audience. Unforcunately, members of alf the vabous schools of theught imolved in the dethate may be accused of this kind of heluwior, leaving ene with the distinct impression that no cene is coerpletely right.

However. the unavoidatie facts are thesk: engincering design has evisted in one fonm or ancther since ancient times. In this interval, design has changed - enowed - not only in respeese so cur crer-increasing undentanding of the physical univene, but also in ocher, relasively arbitrary ways responding to fortes not particularfy nobural: sociological. prychoblopical, emviesmental, govemmental, and political, All these forces have had a hand in shaping design as it is now, and their continued intuence has roguired designers and decign sesearchen to adaps to their exigencies. 
The oene constant throeghoul the history of engineering design has ben that the nequirentents placed on Aesigners and on the products they design huve continually increased in complexity. Similarly, as we gain aiore knowledpe about the universe, that much more infomation can be appliod to the problems we hive so solve. The coenplexity of most current-day desitn problcms is many endes of magnitude greaber than that of problems faced by the designers of the las century, and there is no reaven to suspect that this trend will change in the futuse. Conespondingly, in ender to met the challenge of todays desiga pectems, we mus leam wo manage all the infomation at cur disposal in an efficiene, concise and timely manner.

Decign neseanchers afe thas faced with the tad of draling with this complexiny; sinfly igtoring it is unaceeptable. In response to this challenges a sew field of research has emergod: design sheary. liss gods aee (a) to mespond to the incteasing complexity of engineering design pobblems, (b) to increase consdence in our solutions to the desipn problems of the futere, and (c) to overcome limitatiots and difficulties assccialod with the process of desien by prwiding mone corsistent, legically structuned nethodologies and Iechrilques.

Furthering out undentanding of design is a woetwhile god because it leads to verifiable explanaticns of the phenomemon of design. Mistorically, explanations of this kind in other felds fsuch as ptrysics, medicine, ene.) buve lad to progress, avancemest, and new insights inbo the nature of the phenomcron.

Mary segments of the desiga process are seill based in large meacurt on athitnry, ad-hoc decivions and processes. Still, devien theory has provided a foeal point for the efforts of hundrats of rescatchers, and their work has already made aceatle contributions sowands the goals stated above. It marks the beginaing of a new sage in the evolution of design a renuissance ef sons; we, as designers, are collectively and for the firs time aftempeing io examine our oole in society, and so examine design itcelf critically, obioctively. logically. Hodding design thoory as a cenenal concept, mestatwers ane striving towand a level of formal rigor in engincering esign. a certain scientife legitimacy that hak, to dade, been nather clusive,

In the wcent past, engineering design has becn ocnsidenod largely an "art" of cven a "skill", an endeawoe not amenable so fomaliration and scicntific scrutimy. This is clanging: the insoduction of expen and astomaned systems, quankitutive cognitive design reseanch, new nethosologies such as conournen ergincering, new foms of matheanates (for exartple, fuzxy logic) and ether technclogical and scientific itnovations ane permitting a new view of desige to develop, a view in which iechnology and creativity. seicree and irtaition are linked in a symbiotic nelationdrip, fomning a whole that is greater than the sum of 
its parts. It is not uslike the Renaissance, daring which time sclence grew from a highly mystical practice to the auch mone rational, reanechle, and far more esefal endeavor, it is loday. As this materation poocess continaes. we will have to examine the engineering desipn enterprise and possibly change our ideas abou what it neally is. In soder wo be successful, every eflort must be made to maierain a texihle yet definitvo framewok within which design and devign thecry can evolve in a formal manner.

It is this auther's hamble desise to coneritule to this endeavor, and to help the enginocrine profession develop to ies nest plateau.

\subsection{Premises}

The selevance of the work prescnied hervin depends on the acecpance of certain premises. These preatises cannot be poved in any mathematical er logical sense of the wosl because they afe crinalogical, that is. they are cmpirical. deriving disoctly from obecrvatioe of the state of design and of reality. As such, the sost that can possibly be expected is to provide safficient empitical cvidcace to suggest an acceptable degree of confidence.

These premives ave discussed here, $x$ the outset, so as to deine the boundaries within which the nest of this wodk exists.

Devign is not well-underseced. There is noclear, precise delinition of what design is. It has, for example.

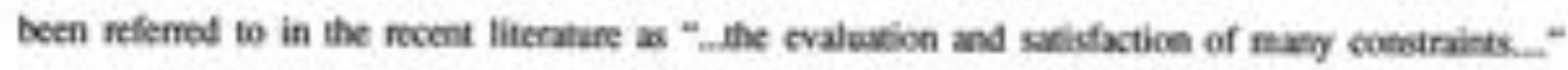
[2]: "-plarning for masufacture.." [3]; a largely intellectual, cognitive process [4]; an ". inlidefined ant.which loks formal delinition." IS]; a scenewhat "mystical" process [6]; a ", socially modiatod

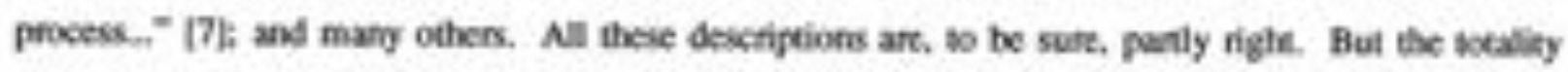
of what is imolved in desige is lost in each ease. Certainly. many reseanchers huve been motivasod to ferform design rescarch expressly due to the apparent lack of current undenstanding [8,9].

Desige is not currently efliciently performed or taught. In a nocent neport [10], the Nasienal Rescatch Councit (USA) has taken the position that engincering design elucation is weak, and that this weakness

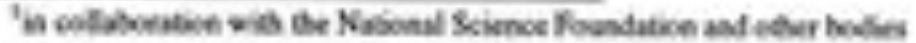


is preventing the best available design peactices from raching indastry. This point of view has been advocatod widely, both in the Unined Sates. and in Carada [11, 12]. Edecases must find new ways to conmunicauc effectively to stodents if these sudents ane to scenoday design effectively. But without a good enderstanling of whar desipn is and hew it is performad, suct necessary communication is inposible. Thus, the burden faully lies with researchers, who med advance cur basic undentanding of design.

Formal theories of desien would lead to improved peactical methodolegies. A fomal theory is a logical, objocthe system for the maintenance of knowlodge and the investigation of phenomena. Formal theories are the comersicne of both the nusaral and enpineering sciences. The edaklishment of fomal theories of design may prwide the benefits to designen that they have provided to scientists. This notion has bees echood by other sesearchen $(\mathrm{eg},[13,14]$.

It is posvitle to formalize at least segments of the design process. A number of methodologies and Itchniques already exist, defined hax Ieast informal iems, the have provided considerable insiphts, if ant into the nasure of devign itself, then at leat into the more practical aupects of the enginctring endervof. The structuse currently used every day in design processes all over the world did not esist a century, of even a decale, apo. There is no indication the we have yet exhousted all the dircctions in which such a structure can exaend. Whether the design process as a whole can be entinely aumemalted nomains an open quesions still, thene are masy arcis whene incteased formalization is possible and desiralle. The advantages are numerous: improved commuricxions and tools for leaching, more reliable and/ysis of designs for correctnesk, indonaation inegrity and shoener develogeners times ane but a few [15].

\subsection{Statement of Thesis}

The thesis of this work is: alicmatic set theory povides a basis whenely design ieformation can

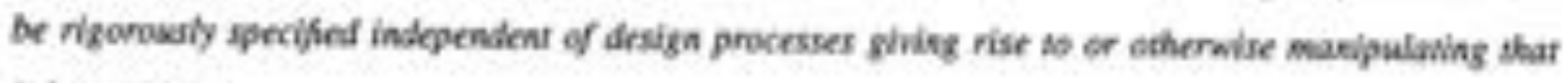
information.

This staneneat explurs the essence of a ausber of argumenes, all of whish will be presented and

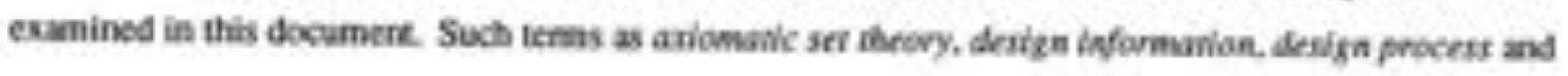


so co will be defined where possible in acocotance with commonly acceptod peactice; in soete caves, where coeversional defiritions are vage or improcise, an attempt will be made to specify them moee fully. Soree lems, swch as isomsrphism, have secific denctations in logie, since this work focuses on the use of logic, we will use the bgical racher than engineering defnitions. A glossary of important sems is provided at the heginning of this docamere.

The hean of the wotk focuses os the derivation of a foenal syocm callod the Hybrid Modet of desiga information (HM), the syctem oonsises of nine axioms and varioes defeitions and theorets. The avioms captuse essential properties of design indomation withis a kgical franework, inclading frve abuaraction wechanisus that permit the organization of information according to various criteria. The axioms wial be

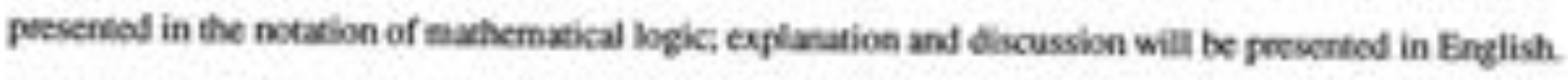
In order to demcestrace the application of formal systens to fractical isues in engineering desigs a new programmisg language foe enginetring computation, called Deskevex, shall be peckenbed. Dessovex eelies on HM for rigor. It repesients a computational model that capoures arbitrary information about specific design cntities and permits the organiraion of that indomation: in is sof intendod to capture methodotogical or pocedural information about the design reccess itself. It will te shown that a strong coetinuity of logical rigot exists from HM theugh to the implementatice of Desscere. Various examples

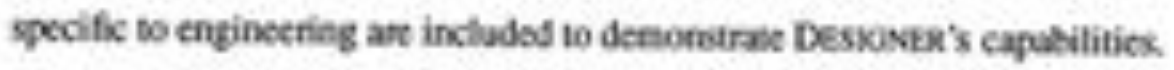

Given the sovelty of design theory as a field of reseanch, a significane body of fondanental wedk does not yet exist. This is indicaled in the premises (Section 1.2). The asthor's work must semain somewhot general, if for no other reasen than this. In the poocess of developing the theories and ideas presenned Berein, the author has also developod a number of collaneral noticns which, though not dirncily assoclaned with the procise bopic ef this acek, impact upon it in an ancillary capacity. This material is monctheless rekvant and original, and is included in this document for the sabe of completeness.

With this in mind, the author also defines the thesis of this work is a broader sense, numely that ate ase of formal logic con significantly inpove ow uadersanding of dessign, and prewide a francwork within which highty fifctive nools for managing the complexiry of desige cas be generared. The answer to the question of the specife thesls of this work, sciod at the beginning of this Section, will be used to comoborane this move Bercral satemere.

It is noted that this dicsertation directly addresses what is given in [4] as the frot mistake of current 
Ecsign efucatioes "We have done very litle research to develop a fundamental scientific usdersianding of engisering design processes. "

\subsection{General Remarks}

As design theory eotinoes bo gain acoeptance and popularity, the erganizational aspects of these rescach efforts will boome increasingly importane. Successful ofenizational techniques rely ce the detection of, and acoommodation to, the structure that exists within infoenation available to devigners. The creation of these fechnigues nust eccur in a Isgiral fachion. Paraphraxing Quine [16], the truths of logic may be rockoned among the truths of design, thas making begic an escential busis of its formal understanding. Thoouphout this ocek, azuments sill be structurd in as logical a manner as is possible, and logic will be imoked ellen as the basis upon which we will make cur observations.

Effons in design thoory have rightly depended en the sse of computen boe their capocity bo store informatios accurabely and to calculane and maintain the complex felationstips thot exist betwetn data. As is noted in [17]. "-the human brain is bener able wo reognine than recall_.." Conpulen, with their relatively infallible memories, aet of grea assistance in this regant. Funthemore, as the world econcmy coetinues to move from a prodact and service base to an inforation base, infomation management isues in design will become move inportan $[7,18-20]$.

Design reseach is the recent past has examined the use of duabuses, application-specific languages and expert systems, as well as more thecectical stadies in sach areas as censtraint satisfaction and symbelic computation. These tools have been afolied with vaying degrees of suceess to conponent assembly (21). design explorxion $[22,23]$, solid modeling [24], finite element andysis [25], exe. The unigse nature of

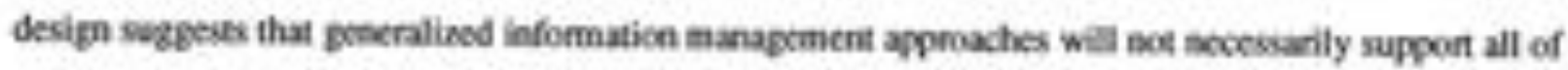
its aspects [26-28].

Ourrently, however, there is growing ocncem segasfing the sowasilcs of engineering design. Mary nocen research efloets huve met with limiled success becase nok enovgh is undersood atout the measing of the infomation we we. The undentanding we do have tends so be cmpirical and intaitive 129,30$)$ and its eganization is neither particularly stnctured mor logical. It response to this, researchen have begen to backtrack, secking a reture to scund, logical first principles in devign. Two notable eximples of this irend 
are [4,31]. The astice of the existosce of formal fins principles for design has guided the auther's work peserenod herein as well.

The importance of the orgaeisation of decign information canoct be ovenemphasined. This issee is stroegly tied wo the search for semartic fomalivabion. To crganive information means to ender it. The inposition of enter on informatice is isentical to the estraction of meaning from it, and makes cuplicit sech infomaison as would othervise be implicit enly. Increasing the amount of explicit informatioe persent in a collection of dea decreases the amount of interpvetation that must be perfomed to extract its semuetios [32,33]. Therefore, the study of organizationd schemes for design indomastion is synonymous with the study of its semantics. The theme of ofganization pervales the asther's wod.

The seanch for a formalizatice foe engineering desige must nocksarily be ecndected in a logical, scientific and intenoally consistent manner [4]. For this porpose, the author has selocied axiomatic set theory and discusses it beiefly in Section 8.2, The mole of logic in design is critical to the developenent of the author's thoory, and will be discussod in detail before the acted theory is prosented.

This documatet is amangod in five Parts. The central three Pants fome the boby of the work. begirning with the most generil and thooretical senats, and procecding towands more specific mamers. Part II will focus on the role logic plays is desigh, indicating some of the shon-comings of the current undentanding of desiga and inficaing taw logic can help resolve these problems.

Part III deals with the central thesis and pesents the Hybrid Model (HM) of design information. Naturally. mo dicussion about design infomusion can be camiod ost withoul nome reference to the design process, but the auther will demonstrate thax it is bech rasenable and atvantagocus to separate information abeut a desiga antifact foom the actions carriod out on or with this information. In is essential to underctand whan foras of informxion awe wallable before any meaningful disewsice meandieg design processes can cocur. Thus, the cheary deals specifrally and only with design isformatian. The design process will be

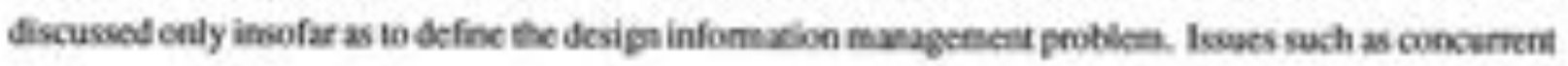
design ane not addressed because they are aspects specific to the design poscess, that is, they affect bos infonnation is manipuleod, but nos the information issetf.

Pan IV will describe a new poogramming paradign devised by the auther, beilt vpos HMC. The intenticen is wo indicane the inmediase benefies thas can be mapod from a fomal theory such as HM, and to providea reuled wide which further research in design theory may be conductod. Varsous design-specific examples 
will demonstrate the capobilities of the resalting cuenpotaional system.

Finally, Pan $\mathrm{V}$ will conclode the work with a peneral discussion of revelis and directions foe furure feseanh

A gloscary of important serms and a list of symbols ace povided an the beyining of the docunent. 


\section{Chapter 2}

\section{Literature Survey}

\subsection{Introduction}

This Chaper will perserk a survey of recent literntese examined in the coure of performing the wok mported herein. Dee bo the relavive youth of design theory as a pesearch field, liserabure directly within the field is not abundare. However, the auther has found a greal deal of infomotion in the peripheral areas of formal logic; compater-aidod enginoering ouscurnest engineering, and compoter science which is relevant to the manter an hand.

Because this dissertation is squacly within the field of design thoory, commens that will appear in this Cupter stall be biasd in that direction. In other wosks, the primary criterion foe the evaluatice of caher research shall be the degre to which it contributes to the everall understanding of devign. In some cases. this coneribution wilt be slight; this does not mean that the surveycd wok is of movaluc, but only that it is of limited use strictly within dedign theory itself. Given the nahure of this survey, literaure dealiag with theoretical appects of compuer programming, as well as fields sach as formal logic and others will not be dealt with Eisoctly.

The author has fownd that the existing literanure can be divided coancly into three categories: Sesign theory, computer aidod engineering, and cognitive and conournert design nstath. These these calepories ate not decoapled; some cross-over is bound to eccur as iecheiques ane apdied to various doenains 
(for esample, the application of a specife design thoory to the zenerabion of a computerinod designer's aide). However, peincipol exentributions by variows kesearchen can be cateporined on the whole using this scheme, it shall be used kere bo help organine this survey.

\subsection{Design Theory}

Surveyed work which the author clascifies as design theoretic in natere is hallnarked by thee peoperties. Finc, exmpster toctroologies are not esseritial so the contribution of the work; that is, the principol

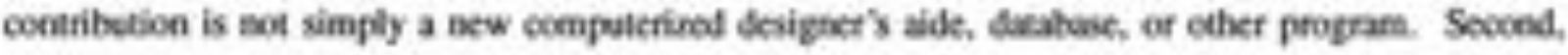
design theoretic work aims at a unifled view of design in the most globel sense, not onlly as it affects some very specific tack within design (Gor example, synthesis and analysiss of mechanisms [34]). Although such work may contain strong theoretic elements, it is mot design theory becaese it deals with specific tads and encludes issues of inbegrasion widh ether aspects of the design endeavoe. Thind, the role of the devigner is not central to the \&evelopment of the work; this excludes ispues of cognition, intuition, jadgnent, efe.

The efforts of two reseaschers in particular afe exemplary of the wodk currnily being done in design theor:

Nam P. Suh has rccently published a text [31] =herein he sets forth an axicmatic theory of decign. Suh ascumes that a design poblem can be strod in serms of funcrional requireneses (FRs) and that its sclation. a dosign artifact. is definod in ierms of a number of desige panamesers (DP). He argaes for this arpouch basod on the enpirical evidence of how design pooblems are cemenenly stated, and how their solstions are commonly specified.

Baved en this asumption, his theory contains only two axioms, eigh coollaries and sixicen theoseme. We will esamine only the asioms here, since the conollaries asd theceens aay be derived from them. The first axiom is that the FRs of a desiga problem should be independent of each other 0.e. uncoupled). He argees that covpled functional roquirements indicate some misconception of the design protlent; several examples ane powidod bo support this notion. The scoond axicon of Sah's theory is that the leformation coetient of a design specification should be mininized. The intention here is to cnvere that there is no deplicatod infomation or information arising froes coupling betwetn Frs. It is shown that, all else being

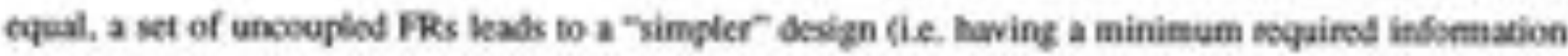


corkent) tean an equivalent set of couplod FRs.

Suh's theory does not formally define an exact procodure so be followed in an arbitriry case in ender to find an appropriate solution, but ralker defines a collection of rules that a designer can ust 10 analyze a design protiem and zuide evabuation and suboquent iterzive rodevign of a solution unil in becomes solisfactory.

Altwough the theory is for the most pan presenbed in Enplich. a chapeer is reservod near the end of the book for a redakenent of Ac theory in the language of prodicane logic. This author notes that though the statement of Sah's theory is amensble to repesentation in prodicate logic, a number of important

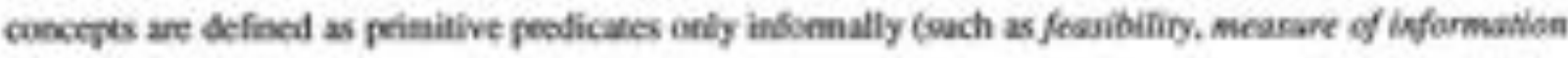
coever, and cowpliegl. Since logic is a ficld wherein an arpument is only as strong as its weakcst link. such informality at the very outset of the presentation can only be taken as a shorooming of the thoory.

Nonetheless, the text is poplete withexamples rnging from the design of acas operier vo the se-organivation

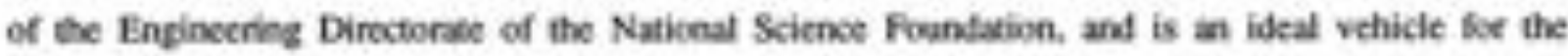
inteduction of legical structured thinking processes inbo the field of desipn, both as an oducational wol and as a generd keference.

The secoed principul contribueses design theory is John Dxon ( $\mathrm{el}$ af) who, in numerous papers and anticles

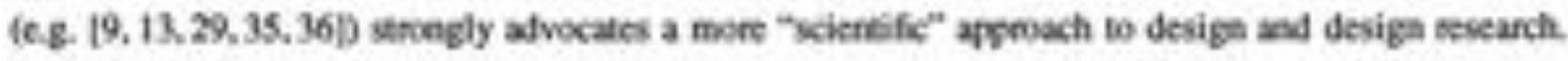
Rarther than the genenilly philosophic approach taken by Soh. Divon's work centers on esperimentation

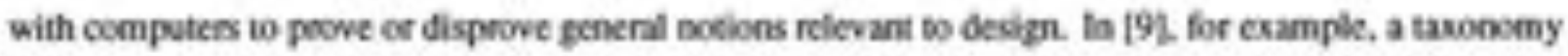
for various kinds of design problens is descrited. The criterion for ascribing a penticular pooticm bo ose kint of another is besed on the nanure of the initial state of knewledge when the peclem is defined, and the final state of knowledge at the problem 's solution. For exmple, phenomenological destgn is characierinod by a fanction wo be supplied and a physical phenomenoe that will povide than function. Each kind of design problem thus nocogrimod, argues Dixon, sagposts a class of solution methods. Thus the taxonomy of design problems is seen as leading 10 a comespending uscmomy of devign methodslogies. As these tawonomies becoene moee detailed, Dixcen aleo mports en varioss softwant systems devised to satisfy tasoncenic and odher noquifenents. The sydems afe then used no decicmaine whot advantages afe poevided. if asy, by the appeoach. The atain contnibutice of Dixon's wok is seen by this anthof as the explanation of the nature of varios kinds of dedign peoblems and the classificution of known and newly devised solution 


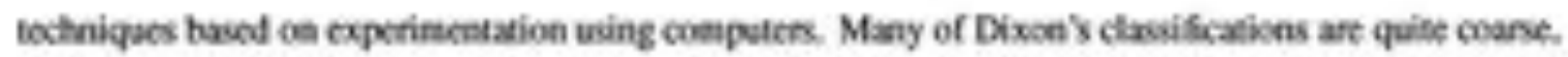
but since no oether tawomic sycuens have yet been widely accepted, he has linte alvemative. Two other Clasuifeatices that le and his co-wcokers hove afvocaled inclsde; the scparatice of design ieto (a) design pooblems, (b) the peogle wbo perfom design and (c) the environment within which design occus 137): and catezorization of design theories as prescriptiel' (tending to describe bow decign showld be carriod cuth, cognitivedescriptive (describing itar design secks bo achieve) and computational (fomalizalon Erough coenputerization) [38]. These syacris all sock to pewide fesible sools so guide fesearches wowands a better understanding of the nature of design, raher than a series of degid, inflecible structures defining exactly the natae of desien as a pocess.

Involat as parcly theortic reseanch is exncensed, special comment should be also made of three ofher efforts:

The first is the Exiended Genenal Design Thoogy peoposed by Yoshikawa in [39]. The imponance of this work is throefold: firstly, it was a fairly early amenpt to enploy some techriques of logic to discuss the natue of design, secondly, it sosghe to place design in a aore glotul framework and disousced the relationship betwoen dcsign and such fields as physics, peilosopty, and tecthobegy, by represeating the utivene as perceived by man as divided inso three distinct domains: logical, conceptraf and physicat. thindly. Yoshikawa was ene of the finst to afvocale the distinction between whar design is verous how design is performod. From this stanting poine, Yoskikawa befan imestigating the nusure of design, thes including from the very outset the notion that design must eccur within an emiennmen, by which in is aflociod and whikh it affocts. This view of engincering as pan of the human experience has mone rocently becoeta quibe relevart in mationally nandacod efforts to improve desigen as an endeavor [10].

The secotd is the notion ed recturaive desige as proposed by Wand [40]. Desipn is seen as recursive (nather than iterative) incaes where the design pobblen may be bokes down inos smaller and smallefcoenpenens by the recursive applicationef seme single methodology. This dillen frue the more ocevereicnal iterative appoach in that an ilierative design process is apliod many times to a detailed design altemasive, its goul being coenvergence of successive solutions whes compared to an exvemally defined set of criteria. The advareape of recunive design is its ability to inplicitly handle a wide number of design altematives. something that typical inerative secheiques $\Delta o$ not $b$ well. However. if the resulting tree structure of all

\footnotetext{
'sumelimes seforod os is noresarive.
} 
altenarives in a recursive design proctss is not cartully "peanod" to eliminate unacoepoble designs as eafly as possille. il cae lead io an intractable namber of solutions. The nocon of recursive design is quile new, bat shows some poichtial. espocially in concument engincering enviecenments.

The third and last notable thoonetic effon is that of Favel [41] In his approach so modeling desigh, no emphasis is placed en any one aspect. Racher, two ahuract notioes, embodimese and acrivily, are wed wo model any design eatity. An activity is any procebure or methodology used by a designer, an enbediment is the revalting eflect of that poocoture er methodology on a design. This essenitially functiced aprosch is particularly flexible and capable of providing an integraing franework foe the overall desiga endeavor. It is also reminiscent of the model developed in this thesis (soe Soction 8.1).

Dixes is alwe a lealing proponent of so-called feanur-based design (6.g. [42-45], A feature is pencrally cotridered to be a modeling entity more immediately relevare to design and manufacturing than a simple sclid of other poometric model. In is oflen esed in conectice with efforts 60 incerate design and manufactaring. However, even Dixen himisef states that the exact natuse of a feature has yet to be

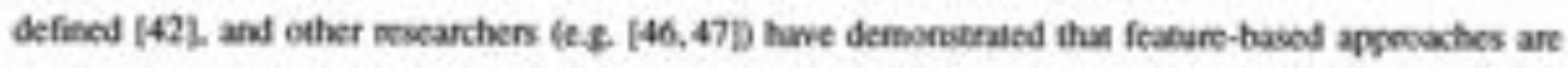
not coenputationalty feasible over large feanure sets. Nonetheless, the importance of feasures as modeling structures makes it worthy of note here. Unfortunately, reseanchers have alnost imvariably treated features: as the basis foe the construction of sotwae systens nather than legitimane concepeual structures io aid is the generasion of design theceies; nonethelcss, since we afe interested in desigs theory and not enginocring

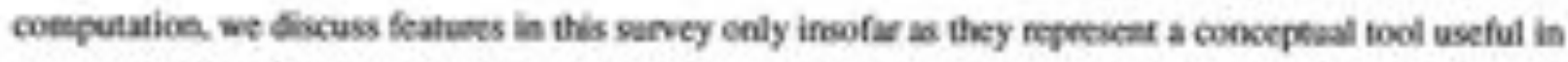
design theory. Dixce is cne of the few who have used the nocon of a festure to guide the development of ais design reseach. Features huve found use in the study and generation of casommies of desiga entities [48,49], foenal larguabs for the specification of spacial relaeicnolips [50,5]], and the integration of design and manufacturing [52-54]

Anceher area whercin a great deal of work of a design thesectic nabure has beco bone is the area of coermaies. A constraint is generally dethed as seme kind of nelationship betwoen variables er parameters that mutricts the set of acceptable values that the variables may have assigned to them. Consanints capturt a peveriction placed on a decign by the nature of the devign pmblim; thus all constralnts con a panicular Acrign must be satistled for the Asiga to represent a possible solution. The conuraint sutisfaction problem has been devermiked in the general cave to be NP-conplese [S5,56) that is, all but trivial cases 
at coenpuationally introctable [57], Constrinss also affect design optimization and simulation [58-62]. Thus, fnding aliemative straepies for dealing with constraints femains an active reseanch arta

The fins real menge so treat the notion of "conotrain" as a nodeliag tool auchematically appears to have boen by Friedman and Leoedes [63-65], wherein nod only a general mathemalical treatmemt of cosumalst theory was given, but various kinds of conctraints melovant to the enginetring domain wese examinod.

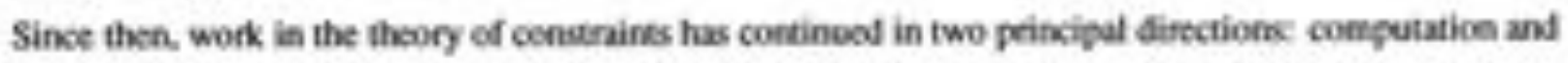
theory. The coenpustional aspects of coestraints will be discussed in the neat Sectice. Inofar as the theoretic aspects of constrains as coectemed. many efforts have been discted in the wise of condraint theory to optintise desigr, notably, the work of wilde $[66]$ who introdused the notion of manomankith and established several principles by which mosowonicity can be used to optimize mathematical medels of design artifaxts. All this work has betn continead by many ethers, incloding $[2,22,58,67-72]$. Alse, various specific aspocts of constnint theory as applied to design have attratiod the ateation of reseachers: the role of condmints in discrele even systens for modeling design processes $[73,74\}$; the representation of spatial censtrains to motel shape ans ptyolical structure [75, 76) calegodiratioe of constrainss types [77]; and the use of constrint netwods as models of design processes [78],

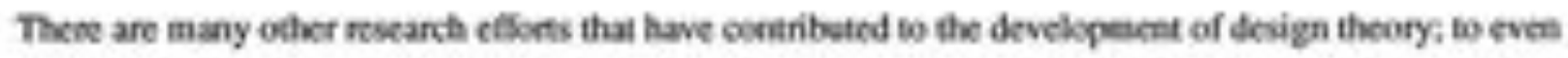
mention then all is an intractuble proposition. However, a glimpse of a few can indicate the depeth and rictness of ongoing rescanch of potential nelevince:

Various maxhematical and logical foms have found their way into design theory, with the goal ef advancing He integration of otherwise disjoint aspects of desige, inclading: peobubelity and furry logic applied to the mepresentation of uncentainty in the design process, especially in sop-down approscties $[47,79]$; proficane calculus [30) appliod to the capture of design kasolodge [14]; and inegration through the use of infomation matagement tectriques and infornason theory [81-83].

The developeacent of genenl methodologic framewonss for parsoular sab-domains of the general design process has attractiod coesiderable startion, incloding Design for Marufacture (and Assembly) [S4]. design for quality [85]. genenalized sectniques to assiat in the erganization of design knowlodge for the sake of simplifying its coetplexity [86-89! and efforts to create viable tavonomies or classification systens for devizn protiems, methods of entities $[17,59,90\}$. 


\subsection{Computer-Aided Engineering}

Into this categon falls the majority of the work (over 50\%) of which the author is awan, and coesises of models and actual implementations of coespterined design addes, Elforts is coenpoter-aided engineering often have implicitly defised within them nodels or portices of models of design in genenal. This has becn nocessary becase foenal buses for design do noe yes exist. Indeed, the neod for formalisms for design information and processes is chen nepoled as an essential prenequisite fee achieving integrated computtrined design sndens [91,92]. Such conceptual models and fomalisms zuibe the development of softwane systems. The motivation for the developrecet of the concepoual model arises primarily from the requirements of software sesign, rather than from the requinemonts of scoign in gencral. In maxy cases, this has resulted in confusbon betwoen tho nodeling roquirements of design and the exigencies of coespuer prograstming. We defer a detalled examination of this issue to Soctice 4.3; Bete, we shall exanine the breadth and noure of rocene wod by other researchers. As indicated in the introdvction to

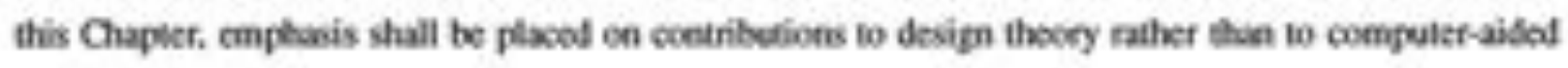
enpineering.

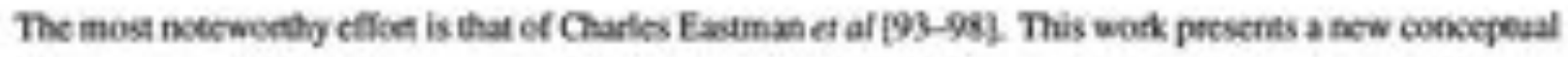
data model, called the Enpinoering Dasa Model (LDM). that defines classes of desienod prodects callod product reodels. The cuntent of a prodsct model cornesponds to a sevign database schema (i.e. the organixational structure of a design dasahece. not ncckssanily the actual data within ito. One of the major atvarkages of EDM is thas it is entincly independers of bech hardware and sofware consideratione: this separation greatly simplifies the system, permining clearer definition of importart notions for design without the need fee actedl computation. Addisionally, notioes of foenal logic aft used as the buse upon which EDM is boilic; this provides rigor so permil the "conectness" of a particular pooduct model to be

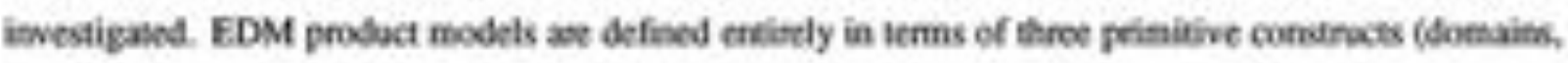
agzregations and contrains) ples screral higher level exnstracts bailt up from the primitives.

The importan coneribution of Exsanan's work toom the peint of view of design theory is that EDM powides a formal structure for devign information, albeit for the expeess reason of generating databuse schama. This structurt could be wicd to examise the nueure ef desigg information itself. In this regand, EDM is uricue in all the work of which this author is awafe for its completencss and rigot. 
However, there are two shortcomings in FDM that this author feels are significart. Firsily. EDM is a descripotive (oe declanalve) form, as epposed so as axbecatic form. EDM is mean to penit. amone other things, reavening about product models, but a descriptive form foes aot provide the apperatus to perfoen this reasceing in a formal manket [99]. As well, descriptive forms have been found so be doenain-dependent, which can lead io difficulties in corroulability [100]. Axbomatic systems, en the ether

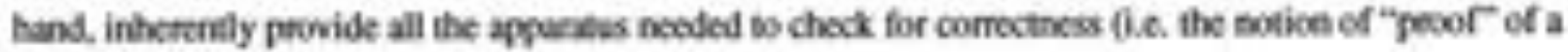
model) and systematic model constection.

Socosdly, although EDM remains qaite detached froen the exigencies of computer programming. the fact that it is a dasa modef requires it to text such issues as identify (0.e, naming, equaliny, erc) focm a computational point of view, This intoduction of computaticnal isves can unecessarily complicate imestigations geapd to the study of docign information in general.

Another notable contribubion is that of Craw ford and Andersos [75.101], in which a computerized sysers for general modeling of desigs is presended. The key advantage is that the system is capable of modeling solution processes as well as desigh protems thenselves. In this way, a higher level of unification is achieved than in other efforts, and different catcgories of solution accheiques can be established wo assist in solving novel \&esign problems. However, as is typical in these efforts, the strictly descripeive amibude taken in the work limils the use of the popposed syaea to the study and andysis of designs. Also, the connection between the proposed system and fomal baves (e.e. logic) are not examined. thas raiking questions as to whether the validity of the system can be demonstrated.

The need to eapress structure as an essentivl propenty of data in a comperabonal eminonment has encouraged the development of various tasonomiec, isclufing tawonemies foe design decisions f100\%. for mechanical sysiems [17], for design taks [102], and for semarkic operations on design knowlodge [29, 103]. As welt. to capture the probelard aspects of design, namerow models of design have been suggestod. inchading meta-model evolution [102] the molecular data model [104], the statelrafsition model [108], the structural data model [106], and multi-layered logic [107], These are ableworthy becase

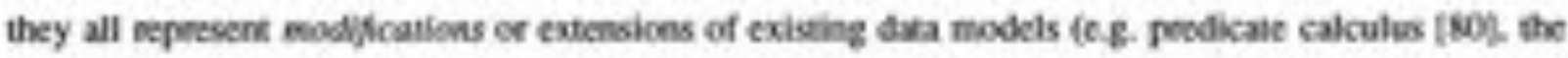

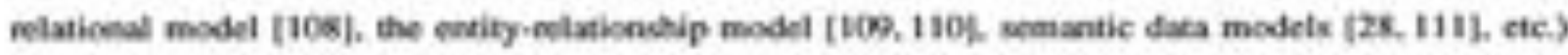
Iexting to the conclusion, sappontad by maly, that conventionat dara modeling iochniques are insufficien for design. This undersoons the nood for additional design theortic rescarch, since we cance depend en 
exlating schemes to poovilo the necdod structurt.

One data modeling techrique deserves spocial mention because it was originally designod to provide seppect expecially for non-corventional applications such as engineering, and because it has becorte the most popstar approach to managing infonaation: objecr-oriestation. Though a detailed discussion of the nature of objoctoricnation is utrwarrand here, it is quihe nelevant to distinguish it as possibly the mosk promising approsch wo design inbormatios manabemen yed devised. In panticular, the objoct-orieniod

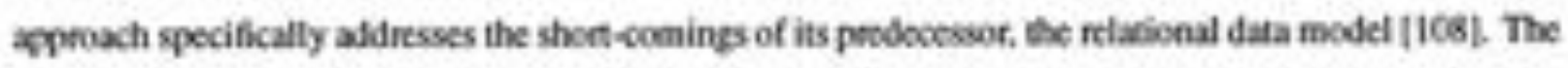
selationd model was conceived so adress the needs of business and commencial applications, but as many dedign researchers hwe indicated, design's data modeling requinements ane quite sefferet from bose of other application domains [25,93,112-113]. In particular, objoct-orientatioe is seen as powiding a far relker set of atwtractices foe the conernation and cequaization of design miodkls, independesce from implementation issocs, nefoction (for astorexic andysis of desige modelsh unified lenguage definition for beth poogramming and datahuse applicasions, and $50 \mathrm{co}$. From a desipn thooretic point of vicw, object-orientation can permit the obemputer to beowent a moft ssefal sool for investigative studies into the nature of desiga by hiding many of the more mendree and imelevane issues of computation from the uset. It must be noted here the of all aspects of design, concepoual design, arguably the most inportant aupect of the design process, is the leat well undentood of all. This is made abundontly clear by the failure of all arcapts to ccanputerine if $[17,60,119,120]$. Oxe sool has been indicaned, bowever, as a possible solution to this particular problen: parametric decien. In parametric design, details of various components, assemblies, etc. ae ignorod for the sake of capkring in parancterized bonm the essential attribues of

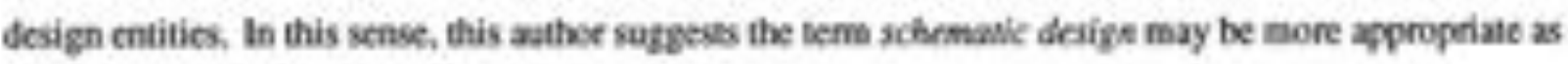
it carries a mone direct cornotation of an abstract nofure and of the inketion to capture cely bose appects thas ave essentially representative of the estitics being designod. Parametric design has been iuvestigaed in detall by ethers. incloding $161.75 .121,122$. Wo noec, however, that two iswes regandine parastetric design remain peoblematic, especially from the point of view of devign theory. First, parametric desiga does not permir cyclic relationahips to esist between datac yet the existerace of sech structures has beca indieated in coestraint networks, especially in conceptual design [122]. Sooond, though parametric design may solve the problem of conceptual deslgn, it has been demonstrabod so be too restrictive for use in opeimiration [61). Whether these poublems indicate a thonconaing in parametric design, or a decper 
inadequacy in ove undensanding of concepoul deslgn, has yet to be detemined. One possible altemotive

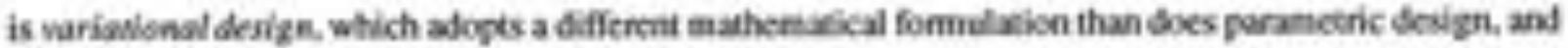
which has been stown to aanage cyclic cosstraint networks well.

Many ether computational appoaches have alow lod to insights into the nature of design. Efforts making use of syonems engineering [83, 101] have demonstrated the esefulness of modular approaches io contiod complesity. Various revearch peojects imolving the constructioe of database syatems foe design have is: Exduced the notices of abumaction mechanisess as techiques bo coganize and insegrate cur undentanding of design is general; these include structural entities like foaturs [2.123], tank-specific views of insoma: tice [S6, 112], and hieranchies, agpegations and other classification fonts [106, 124-126]. Reseanch into the practical aspects of eceserain managemene have provided nunerous approximatiots for the selution of the condrain satisfaction problem (see poevious Section) 128.24, 105, 127-1301,

\subsection{Cognitive and Concurrent Design Research}

The thind category of meseanch is fistinguished by a coecem for undentanding, in whole of in part, the nole of the haman in design; that is, rather than being conoemod finctly with devign itself, workers in this area ate concemed with the mental functions of human designers when they perform design taks. Sistilaty, some revearchen (c.E. 199, 120D have distinguiched between how design is performbd (by hamats) as epposed wo what desige is. Although not commonly considerted together, cognitive design feseanch and concurnert design do shart an interes in the actiots of the designet.

Cogritive design reseach is concemed with what nighe be refernod to as the prychology of design, and secks to explain, ef a least quantify in some manner, the particular montal processes a designer may use. The author alvo includes expert (and other knowlodge-based) syscens reseanch in this catczory, vince these systems model the designer' $\$$ ahility father than design itself of some aspect of it.

Coccurnent engineering, on the other band, is exnemed with socislayical issues. The peinclpal tenet of cencument engineering is that the involvement of all interestod parties in a design pocess from the ouksel can makedly impowe the deckion making abilities of the group as a whole. This kind of design is far more information- and cocolinatioe-intenstve than comcreional, purcly scusestial design processes and thus requines a much mort befined stracky to assure effickene, accurate and tincly communicatice 
between team memben. This nequirement has led to greas activity in the ese of oomputer tools to help document design processes and communicate information betwecn desigsen. Thas, again, the role of the human in tedesign process is the ceatral concem.

\subsubsection{Cognitive Design Research}

This author has several neservarions as to the melevance of cognitive design nescasch to design theory. This issue will be dealt with is depth in Part II. For the curnem discossicen, an abbreviated venice is sufficiene. Very little is undentood of how the human mind fanctions; afditicnally, the outwatl signs of neetal function (grecth, scoturts, etc) do soe necescafily selate diroctly so underlying cognitive process. Indood. there is some evidence to suggen that hirking" as wo nomally coesider it is a purdly uvcoerclow process that we may never difectly observe or even experience [131], Tix detactenent sugests that too much may interfere with any aftempes to control the cognitive function so that it may be observed in a scicntife manner. One is therefoe left doubful of efforts imvolving the use of antificial intelligence techeiques bo create expent systicms and other knowledge-tured systems foe decien which ane all nooted in the posemption of some basic undenanding of the lusan oognitive function.

However, it mus also be said that there have been notable onotribstions to desipn theory made ant necescarily from insividaal effors in cogtitive design reseanch, but rather by the whole of the endervot.

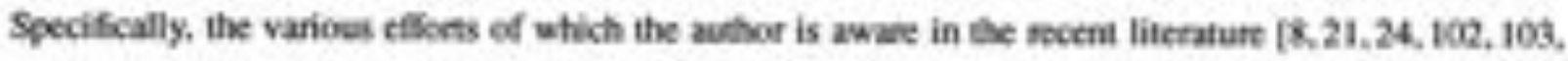
132-136] are supportive of the following observations:

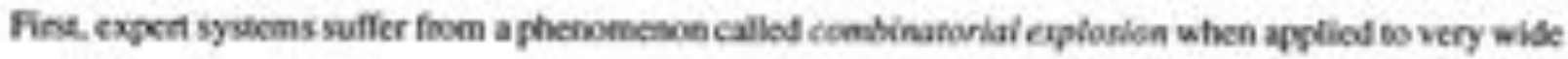
aptication domains. This means that the amour of informatice that mest be marapod by these systems becomes intractably lage as more and more ditleren kinds of problems ane includod. However, for very specific somains, expent sysiems have been known to gencraie neasonably effliclent solutices, This suzgests, as has bech noed in [102. 109], that though the origind goal of expent syscems as the whimate design tools nay never be achieved, they may be very useful as smaller curtooncnts of large, integraed design systems (e.e. the desiga of cams (21D. As well, a very xignificant dependence on tho structures usod to nepresent information is indicaned.

Second. expert systems, like haman designea, rtqaire a certain period darleg which they ane "Uainod op" 
for the kinds of eask they are to perform. During such training perbods, the system will noe perform correctly since it is still leaming. The resowrce drita that mat nocessarily occur dering training of expert systens has net bees adfressed in any of the ellonts of which this author is aware. As well, the infoemaike base upon which expert systems draw duritg this period is often hruristic, Heuridic knowledge is empirical in nature, eften unprovable and wsually based on the knowledge of panticular

experts in a ficld. So, while exper systems may perioen mote rapidly than humans, and ase less likely to be the source of seimple mochinical emon, they will carry with them all the insocuracies of a humas designer.

Thind, the netion of krowledge is not precisely definot. The tem has been associated with both the act of leaming and its results?. This wither is saprisod that sach a vaguely definod notion has been

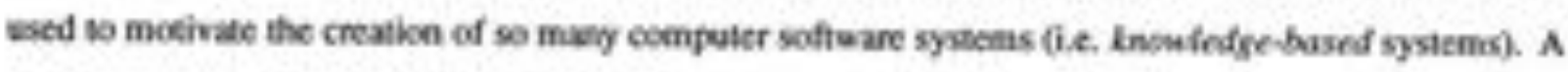
fundamental aspect of these symems is that they can eperane in various "intelligent" ways on infoemation; ene might suppose that knouledge is then tiod to the process of wing information. Bat again, we lack underctanding of how the mind acts ce informasion: we must thenefore suspect any efloct to mimic this behavior computationdly as being based on rasionalieations rather than ral scientific undentancing.

Fourth, as indicated in [24]. most design "knowledge" impartod to expert and other such syoneras tends to be noutine knowledpe. This woeld secm 05 indicate, then, that expert systems would be unable bo expe with new kinds of design problems. This has been indicated not cely in the existing devign rescanth, but also in a more general sense in artificial inteliligence [137-139].

\section{4 .2 Concurrent Fingineering}

Concurrent engincering has enjoged sigrifeatly more success than has cogaitive design mexarch. As gead above, the goal of concurren engineering is to parallelize the desigs process, bringing upstream vasous functices nomally left entil late in the design process (eg, avembly planningl. Enpineering edablisheness that have adopeed coecurren lechaiques hwe bosicd marked savings in time-10-market. develogment and production couk, and wastage [100,117, 140, 141], in wome cases esceosing 50R. The degree of savings has sarprised many, and cased a mumber of neseanchen bo imestigate coscurrent

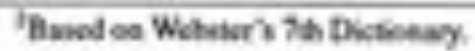


enginecriag with the ain of identifying exactly how these savings are achicvod. This work is ob-poing and very few revils of conseguence lave becn reported. However, reseanches bave idencifiod that communication of information is likely the key to effective concurnent engincering.

Effoctive communicytice in a technical field such as desiga nequires a formalizod notation for the specifcasion of infoenarbon (i.e. a longwgen) and a fesible yet strict tramewok within which infonmation can be arranged and erganized [107], This has lod to the adspeicen of hyperien (also called mini-mediv) as a key computational tool for concurren engineering mesanch $(32,135,142-144)$, In casence, hypeneat is a modeling technieque for infommation upen which noorganirasional schema is awalable a-priori. Thas users ef bypertext systems not enly supdy the inforaution bet also the varnous "Tocks" by waich the system ean organine the information. The important contribution of such systems is that information that would otherwise have been enly implicit (feccause no schema exists to capoure it) can be mabe explicit (81]. Here is cone possible use of expert systems to aid designen, though indioctly. A suilably trained system could examine a hypenext durabase and organize it aconding to various other schema identifiod as signifcant in a desiga emimnent. This ifea has get to be meseanched.

Finally, becase oncurnent engineering places peat imperence ee the coecoptual stages of a design proces, a number of cegritive researchers have investiguad the noture of communication betwecn growp members in concurem engineering teans $[7,47,135,145,146 \%$ and have identified varicus tochnigues of "negotiation" and sharing of ksowlodge whertby group decision making can be ascisted by various formal tectaiques (ez, cavo-based ecascning [145]. It is noted in closing that cogritive rescanch has had a mont noticeable iapact on concurnent engineerine, posibly bocase of the increased availability of edtemulined evidence (communication between group mombers) of the dedign proctis.

\subsection{Summary}

This Chapter has presented a survey of recent liserature on design lieory and the associanod fields of ocmpoteralded engineering, concurnent engincering and cognitive design rescarch. On the whole, the body of work, thoagh not particularly voluminous due to the relative youth of the field, clearly indicates a procecupation with the integration of the vassous aspects of desizn. Sone rescanch has deall with specific Deortical aspects of design (sach as condrain satisfaction), wheneas ether effonts have been larger and 
kss detailed in scope, seeking a general frastework where particular efforts may be seamlessly combined. Some successes have been denonstrad as the realts of this rescach percolate from nesarch imstitutions. into industry, but thene is as yet no consenas as to the find form of a folly insegrated design endeavoe. Nonetheless, the saccesses achieved to date inficate that the principle of an integrated view of sesign is worthy of funther stufy: 


\section{Part II}

\section{THE ROLE OF LOGIC IN DESIGN}




\section{Chapter 3}

\section{Introduction}

The approsch uvod in this work is quile novel: though sools of logic - ach as set theory and prodicate calculus - have ofien been itwoked in suppeting noles in devign thecery, there is mevidence of any work in design that taks logic as its sole foundason. The arthor finds that the uniquences of this acproach warrats some explanation, and that te explanation irself can go a long way to clarify the nature of enginoering desigh and indicate wass in which moee sobur formaliens cas be achieved.

The purpese of this Pan is twofold. Finst, the generd nole of logic is design theory will be discusuod. Some of the portlems confronting design theorists will be exanined, and possible solutions based on the apslicakice of logie will be coesidend. A faidy wide range of sopics will be coverad, bus the underlying notions are few and distinct. Shoond, a namber of terms and notices of logic that are not panticularly well-known in decign - but that will be used exicnsively is the Parts to follow - will be introboced and divessed in detall.

Some important notions should be introducod before any ether ecosideratice, because of their importance in the seguel, Find, we define logie as " the study of nethods and principles used in diutinguishing

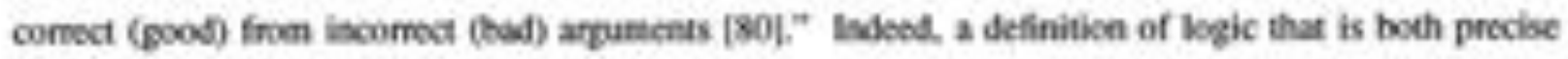
and compact is diffcult to find sinse sach a defirition would wo sone degree depend en logic itself for correctness, and, as shall be shown, the validity of sach self-dependent definitioes is swapect. Forturabely. great effoet tas been expended by phllosophers and other tainkers to resolve this problems the inserested rader is refersed wo the introduction in [16], where the overall natuse of logic is discrused very clearly if 
scenewhat vertosety.

The notion of proof is alse imponant. In logic, a peopesition is proved if a valid argument can be coestructed so as to demcestrate that the proposition is true. This is a well-acecpled, coenentional defieition of the serm for classical foenal logic. Variants esist, depending oe the form of logic usod. For example. in fuzzy logie [14].143] there ane pralusions of tuth thas it is possible to have pecpositions that are more or less true than others. However, for the correne work. classical movnalued fie. true and false) logic is sufficient.

Another imponant notion is that of roinfiry. Validity refers to the correctuess of an argumernt, but not bo the truth-bood ef ies penises. Thus the clessical exanple "If enery man is moval and Socrares is a man. then Socrafes is movnal" can be shewn to be valid without making any statements about the premises

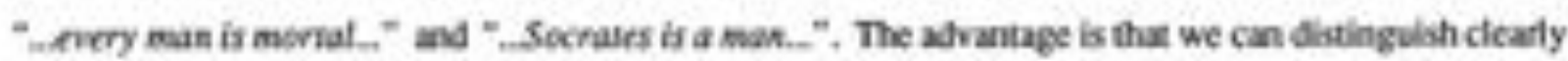
betwoen the permises of an argument and the poxctenes used to reach conclusions. Alsa, logic porvides the means to check those procedures for incorrect intemediary steps. Although bogic may also absist in determining the correctness of the pernikes of an azuatent, this is a separate consideration, Often, pemilses of argunents are basod on observod facts, which are by definition empirical and which usedly cannot be prewed in the technical sense of the wond. Although this restriction may apsear to limit the applicatiliny of logic - especially with respect to a dowain with soch strong physical ties as design - the notion of validity lets us prove er dispeove argumencs, which afe the builing blocks of neasoening and reawning is an escential coespeent in design.

The issue of valldity of particular fomal sysiems is pooblonatic this was cstablishod by GSdel in tis work on incoetpleteness. However, insofar as formal sysiems may be considerod valid, they offer a far mone riporous means of treating plenemena such as design than any other available technique. It thus semains advantageous to employ formal tectniques in desiga thoory.

Logic is convidenod to be independent of the physical utivere; it is for this ferwen that thuth of stanements sach as "... Socroses is a mas..." carnot be decided, Indead, it is possible to genernee fommal systems

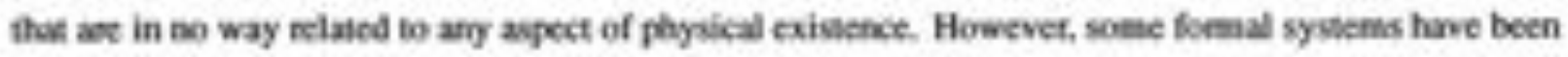
found bo be very usefal in esplaining and peodicting the behavioe of physical (exeralogical) phenonena. As engineers, we are particularfy interested in formal systems that do relate in some way to the ploysical univenc. These formal systems afe cur logical modris of pencmen. The success or failare of a particular 
kgeical model depends ce its perceived oomespondence to the phenomenon being studied. Legicians call the comespondence between a model and an observed part of reality an isomarphisen [149]. The moee accurate and complete the iscenorplism is between a sadel and a phemoescan, the betier the model. The notion of isomomhisms will also play a nie in determining the evtent wo whoh formal thoones for assign can be considered valid, this will be explained in the following Sections.

Furthermone, logic is, ce the whole, objoctive. It is cresiderod to be valid netafless of haman cognitive functicn. It is inceresting to note, however, that these does exist wok in logie meant to bonnaline sach natucally subjoctive domains as belief systems [150]; such work bas found icchnelogical application (foe

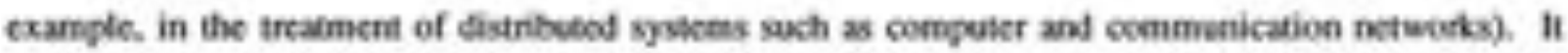
would appear, then, that if we are to maintaik a certain objoctivity in design rescath. logic should be considerod a very important and weflal tool.

To mochrate the discossions to bollow, the prescntation in this Pirt will begin with an examinasion of terminologic and tavosonic issues, and the leherene vaqueneis with which noticns and coscepts in design are currently definod. This view has bech expressed by others in the field, especially Dixon, in [4]. Next. a distinctice is drawn betwten the concepeual models that we use bo undentand desiga plwenomena and the computatiobol models we use bo implement cur eoncepeual models as design ables. This distinction is inportani because it can significandly simplify the coapleairy of design theories. We then exanine the consept of "yelf-nefereace" in the context of design thoogy. Self-eeference can prevent valid formalixations in any domain, the auther aqgues thex it should be wolded in design theory if valid formalizabons ane to be found. Next, the sotion of desiga as an antficial scirnce is introfuced as a means of discussing the pole thot formal logk plays in the establishment of useful franeworks within which design can be studiod. The cesclusices of these discussions motivate the fomulation of two conceptual dedien theoretic tools. The find, a layered logical stucture for dedign, oetlines a technique wheneby differene degrees of abstraction in design information may be identified and clascifed. The secoed, called a desige space, is meant to help stofy the relaticnships betesen varioes notices, methobologies asd appoaches we delign. 


\section{Chapter 4}

\section{Motivating Discussion}

\subsection{Terminologic Considerations}

Then is no dipoross temimology of Enenenclafure for imponant coecepts and motions is engineeriag design. Tenns that designers and devign researchen we ane often definod in whatever fachion is most corvenient to them (e.e. the vahous definitions attribvtod to the iem feature in [13,51-53]2. This is not an indictmen of the abilities of these persons or the quality of their wek, but faher an indictment of ost collective ability to define the natare of devizn itself.

The nearest comcntioe we have in this regand is the engineering drawing. Although bo graphical noture of engineering drawings can capeure soate informasion efficivaty. drawhes abone, even if computerinod (via CAD systems carsol capture all the informobon necessary to represent the nafure of a devign in an efficient and usable way [32.94].

A lack of standardiod nomenclabure results in bod commanication. Between designen, this can have

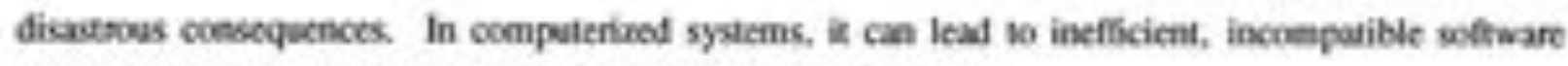
systems that stymie faher than stimblate the abilities of designers.

At a deeper level. this indicabes a sipnificare disagreenent en the limits of boundaries of various nocions and concepes. What is engineering design? What is a solid modet? Af what poist socs a gocenctric mosel become a solid model? Should a finite element mesh be considerol an andytic model parallet to a solid 
model. a panticular manifestation of a profuct model, or an entirely separane kind of model? To what exlent afe constraints a valid modeling form? Is ccestraint theory a modeling technique er a technieque of analysis? These questions indicate just how vapucly desiga is defined, a notion echood in the work of many researthers $[29,31,39,151]$. They carnos be answerd because thene is coesensus neither of boetenclabure not of the associand underlying concopts and nocions.

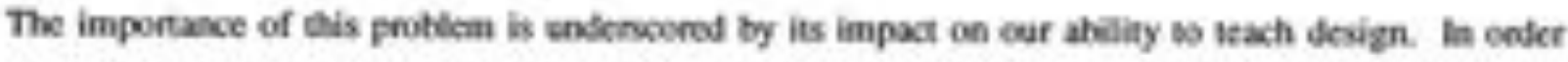
to leach, we must oommunicale effectively. Withou eflective commanication, the inpectition and incoesistencies of the teacher will uend wo be pasud on to the stadere. Thus, the problem perpetuales itself. The selationship betwoen design theory and 1eaching design is discessed in some detail in [4,10,36]. Recognition of key primitive notions is esential to atuin a more fomal understanting of design. The establishnent of mort precise cosceptual definibions and theif comespending teminologies would assist us to rosolve many difficotries now being experiencol.

By simple unalczy, consider the nomenclatue of chemical compounds. For example, a satfite is afferent than a sulfidt, which is different than a sulfare. At ence, these terms cencisely and exactly capture significant differences in composition and behavior of these various classes of distinct, yet relasod. crempounds. The importase of this nomenclatere is not so mach that if ascurately diffencatiaes between various classes of compounds, bue that it eqpesents a collection of very precise definitions and netions thes ase coesisten with the nest of the formal structure called cheaistry.

This kind of peccivion is miscing in desige and design mesearch. As things stand today, it is difficult - if at all prosible - 40 gencrate a nomenclatue of design parallel in precision to that of chemical compounds. However, if this were possible, the benclis to be neapod would be grea. Of primary importance is the incseased efficiency and security of information tranefer. A universally socognized nomenclature woold vietally eliminate the sebjective interprexabon of engineering information and thos greaty diminish the chances of misieverpresarios of thar information. Designers wil thes be able bo spend mone time discusting the funtere of their devigns and less time arpuing over bow the designs afe pessented.

Alsa increased efficiency in coemenication can have important consequences so the developenent of soltware systems meant to asolist the designer. Spocifications for softwane systems will be more fotus because the models they implement will be moere precively specificd. Compuiens ane not yer atle bo deal well - if at all - with vaguely defined dasa. Inpleatentation details wouls be easier to manage if the 
coapusaticeat models of the problem doenains incleded precisely defined notises.

In scarching for a nomenclatuse foe design, it will be up to dosign theory wesarchers to provide the fonnal systems and methods necdod to ascure the valifity of the nomenclature. The toot they will ese to provide if will have to be logic. The auther's propositions in this regard are discossed in Sections 5.1 and 6.2.

\subsection{Taxonomic Considerations}

A taxcentry is an enderly structurod system of classificieion based cen pesumed of observed peoperticx. Taxencmies ane wsed to classify entities and thus permit their soudy al higher (i.e, more general or ahodract) levels thon that of individual ercidies. Tasomenies art also very uxfal in systems conzaining many individuals and naxy different kinds of individeals; being able to dassify individuals can be a grat tool to assist in the managenent of infomation atbout the individaals and low they retase to each ceher.

This poblem is stcely saled by Civenell $c$ al, in [143]:

"One of the most annoying things ... is the feeling that one canns kecp up with this broad literature of things that one should know about. Drawing on prychobigical thoory, it seens that the task of the rescacher mipht be simplified sonewhot by powiding a framewed of orgatixing scheras within which to understand and ahsorts the frigheening amcure of possibly felevant naserial that shculd be dealt with."

One of the importare aspects of tawoomiles is that they neof not be complete and entively correct as provide valuakle axsistance to fescacthen. The taxcoceny usod for the classification of tiving ongaisms is a good example of this. Though it is noe perfact (some disputes sail go en as to the marue of certain otgatisms), is is for me mogr part a highly useful tool in sucla arras as the stady of evolution, animal and agricultural tashandry, teaching, and so on.

Taxoncenies coeld help design theory in many ways and at many levels. At a practical level, they could

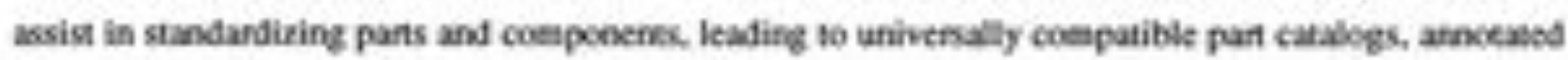
libraries, ete. They coeld be used to classify design processes and so provide a tramework withis which designers can select approgriase rethods for defferent kinds of design poblems. Also, thoy codld assist in the classificatice of marnafactiring tecturiques, promote modalar condroction and thes help not only in 
prodect manafacturing, bot atso in the deslgn of the planes and askenbly facilities used.

In design theory itself, taxowonies coeld help us understand differences and similarities in various theoretical systems, wtich in tum prowide a means to evaloane new ideas. We conld also use this knowlodge to identify classes of protlems that require more research, and criteria that can be used to opcinize their sclations.

Tawonomies for design and desiga research have not yet boen developed, though there hove been varsous artempts $[77,87,152]$. In many caves, the tawonoenics are derived in a generally ad-hoc maner [52] A good tawcoseny mus be tased on formal rexsoning, and the principal criterion used in be searth mest te that of valiefiry. The premises of taxoscenic arguments ave those notions foe which tasoenmies ane sowgh:

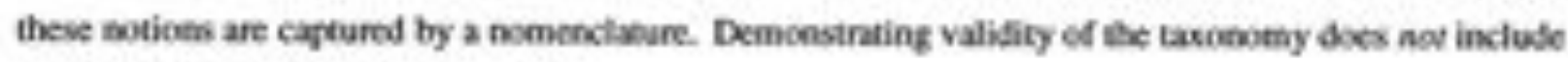
demonserating valificy of the pronises.

Insodar as tawonomies are codering mechaniseas, we can look to logic 60 provile a number of bols 69 facilitate their generation. In Chapter 10, five specific mechanisas by which \&scign information can be ondered will be discussed and demotsirand to be sound with respoct to their logical foundision. These mocharisms can be taken as general principles with wich tasonomies of design entities can be fomed.

\subsection{Computational Considerations}

The authee has noted that mary sugsestod models of design inhenently involve computational aspocts. Examples of twis ane: [117], whene little distinction is made berween the cenceptual problems of classifying Sesign function in mecharical devign and the computational issues sumounding the implementatice of their classifications in computer systens; [126] wherein the factors afocting data bow in a desiga activity are suggested to arise both foen desigs roquintments and fowm tho roquirements of computerized implementatice of their sysem: $[7]$, whertin computationd models of knowledpe engineering ave used as a basis foe formal design process models; $[12\}]$. where imitgrity of stond information is seen as an important aypect ef design; and [125], where a relaticeship is indicalod between the "husiness pecess" of coenputer-iniegrated manofacturing and the maintenance of software. In is noted tha all illese eflocts fall at leat nominally wikhin the domain of design teory, and thas indicafe a posilde melaticeship betwen design theory and compuler science. 
The authof sugests that a divfinction must be made between concepeual and computational models. None of the above-noted models actually require implementations. Each presents a cenain view of design, and conkributes to our undentanding of it, regandless of how the systems are iaplementod. The distinction between implenentation of a tool and the model upon which it is based is temed by the author as the dituinction berecen computarios and concepmalitation, Models can and do exist as formal theories. independest of their implotacntations.

In general, a concepeual molel might peovide fomal descriptions of the kinds of information tut must be present, the kinds of operations that ane defined on the information, integrity and oeter conurains that are to be satisfied, as well as the peneral phibosghic background. A computational model defiscs. the implenentawion of the concepesal model, and nighe specify the kind of sopping' to te exet, atcenic das structures, type-checking semanscs, transaction centrol asd so forth. An appropriate computatioesl model is based in pan on the requirements of the exnceptual model. Problems arising from diflenences

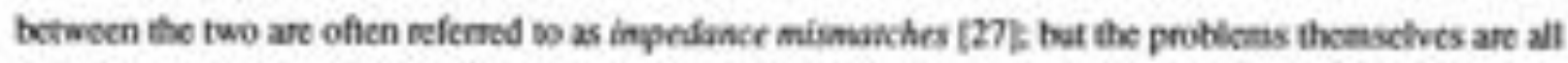
conpasationel pecelerns, and do not necessanly reflect the nuture of the concepoual model itself.

Isvoes of implementation- such as the seloction of a bose programming language (e g. C veross Smaltalk) - can grealy affect the sucoess of a particular model of devign. Also, competueicnal theory cas be a vicfat acel in desige thoory for its ability to fomalize actions and procedures thar maripulate infornation. But in the purely theortic arena, any mechanisn covld be usod. alteit awkrandly. This is due bo the Seterminiatic nature of the computer itself. la ether woth. the implementation boes nos affect the validity of the concerpual model iscilf.

The converse of this is also trot: given a particular implementation, any valid oconceptual model can be captured. To be sure. the efficiency of a particular implementation does depend en the relationship between the model and implenentation nechniques. However, it is noted that the term "efficiency" in this case denotes efficiency of the implementawlan and not of the nodet.

Therefoec, the evaluation of inplementations of models does linte to effectively compare the underlying coecepual models, which should be coaluated on logical grousds bocd on their ability so explain and prodict phetwencha of insertst. The inclusion of issues pertaining to the implemertation of a formal exnceptual system in a coespuberized envinonment can unnocessanily increase the system 's complexity by

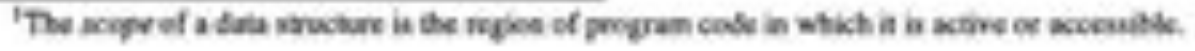


introdscing a false coupling berween the model and the implemerextion. This dses noeling so increase the nobstness and socunt valisity of the model. nor does it venffy or increase the efficiency of the implementaciso.

It is, in fact, pessible lo separate isoues of conceptualixation from those of computasion: [31,40,52] and the work prescnted betein all actieve this scparation at least bo a degroe, and still make meaningful stabenents abost design. Although bese and other relacod eflorts can be used to develop design software systems, the fact that they are net directly tied to the development of seftwave pemits them so be used for a variety of colher reaser, wach as teacting aides and sesearch bools, in non-coetpuberizod arenas.

The author finds it curiovs that model generation for design should have becoete so tightly cennected to the develojment of sof wave sydems, but believes the the connction arose from the historical rooks ef design

theory in the development of the firs CAD systems. Compesers, being deserminitule machines, cannot Seal well with the artitrary nasure of the way desien was ence conducied. Hence, iochniques were scught that made design more amendble as an application for the then encezent computer technologies. Graphic renderine technology is a diroct porgenitor of wada's solid modeling programs [121]: constructive solid goometry itself eventually lod to feacures [5,51]. Since then, our anderstanding of both design and the underlying logic of competasion and inbormation theory have led to the fealivatice tha formal models are esefat and important nools independeat of their use in computational taks.

\subsection{Summary}

In this Chaper, the author has preseneod a discussice intended to motivate the puruit ef a mone coeriplete. formal undentanding of design. In eis regard, we have exaninod temeinologic, taxonomic and competational consiberatiots. There is curnorty no coesenous reganding the definition of important tenus and notions that are ofen used in design research and perctice. Wishost soch a conserrous, misinborpretation

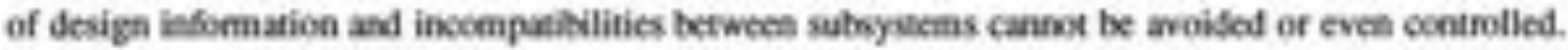

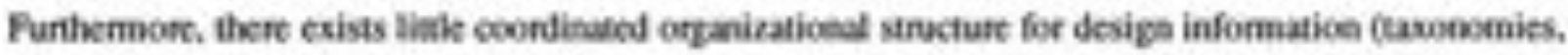
ete.) that can streanline the specificxion and coenmanication of informalice vital to the designendeavor. Finally, the coupling of desien with computatioed condiderations unsccossarily complicates investigations of design. In onder to improve the state of cur undentanding of design all these isspes must be 
abliessed. 


\section{Chapter 5}

\section{A New View of Design}

\subsection{The Notion of Self-Reference}

Hofsadier, in [149], states "It is very inponant when stubying formal sychests bo distinguish working

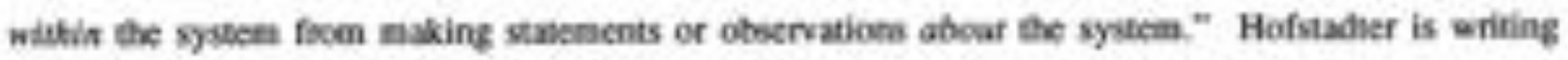
about the coecept of self-referencet, and though in may soen simple etwogh in lis shot quotation, the concept is ene of the mest conplex and consequential of this century. It is a notion fundamental so all the arguments pessent in the stove-cibed. Pulitner Prize wiming wod. Tho problem of self-eference is definot formally by CQdel's Inoompleteness Theoten. which gates that no system can reference itself and be proved valid. A system withot self-refenence will me be able to powe some statements that ate aceecheles valid; a selffreferential sysess, on the other hand, will pemin the proof of all valid statements

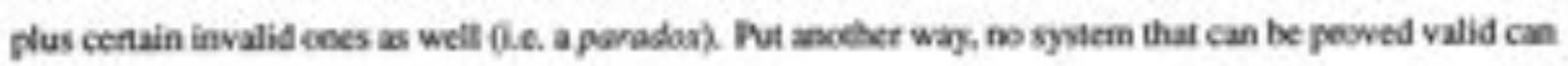
be complete. No other notice of logic has had mope important consequences, and yet been so univenally accepted as necessary. For example, in classical set theory [153], the exisience of the universal set cannet be demosstrased without appealing to self-efiernoc: yet set thoory with self-efierence and the univenal set is easily pooved inecesisene (i.e, containing invalid parts). Moneover, it can be shown that any formal systen that comesponds to number thory throgh an isconceghisen is inoomplete; ie. thene ase some

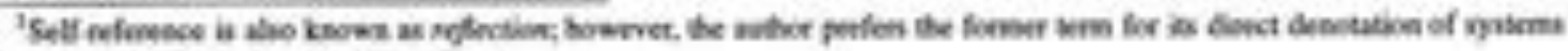

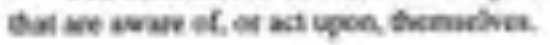


truths that carnot be proved [149, 194).

Although mathematics and begic is limitied in rigor fue wo incompleieness, the fact femains that both these dlsciplines have contribated linestimatly to our undenstanding of the physical universe. Thene is no aprodi seasce to think that similar centribstions wo car understanding of sesign aee not possible.

The kind of parados that can occur in self-refesentidl systems is esempliffed by the sentence "This sernence is false." In fact, self-oefenence abounds in the Englich language (c-g. "This is an english semence."). indicating thx english exenet be proved valid. The fact that such self referential english scniences can be quile meaningful wo humass does not bode sell foe the validity of the human mind. In fact, the mind itself Is self-refereatial; bow else can we think aboet the stind? The mental peocesses that we call "Thinking" are part of an entiny capable of self-reference, and the concem with logic of scholars theough the ages is an effon to jucafy cur thinking processes and validue the resulks theroof. Indeed, self-eefenenoe, or self-awareness, appears to be a propeny unlque to the mind among all roeural phenemena' it is difficult to think of gravity. DNA, or a alplane as being self-arrafe. While the wuther is not swagesting that the mind will forever clode formal andentasding, we do sugest that any formal understanding of the mind will be of a differtnt onder than cur undentanding of other natural phemomena because of the mind's self-referential nature.

Beciuse english, and other notural lxgeages, afe so often used in design 00 communicate information. self-efefenence cal alse appear in cur ideas about devign. A sasement such as "Concepoual design is a component of the design prosess" is self-efeferential; a design process that takes into account progenties of itself is self-referential. Design itsclf tends to be self-referential, as is evidenced by existing nescanck -A majee part of the design activity is conoemed with the develogment of the design process itcuelf [toti" Any self-referential sysien that soeks to foenaline desigs will be begically inconeistent. Funhemoore, in is inpossible so detemine the extend of the incoesistency wotking within the sydent itself. If wo ant to find a reliable, logical sysoen with which so modet design, we mext etsure that it does not contain the notion of self-reference.

The isoac of self-eeference is pertaps cone of the gevatest stumbling Nocks facing design reseanchen, if

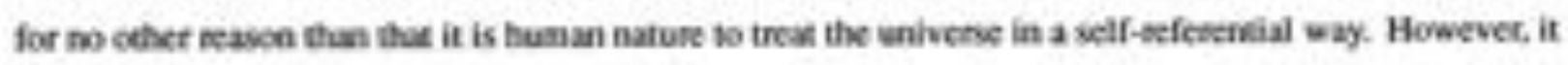
boes seem possible w the author that begirning cartully from fint principles, and striving to avoid tho

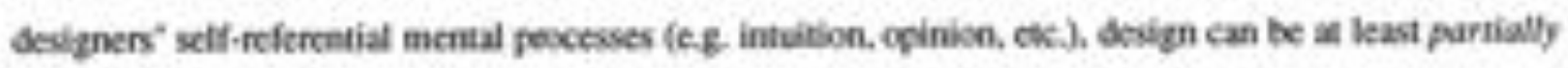


formalized into a sysiem that is valid with mepect to its logical foundation. La the Sections to follow, the author wilt present the beginsings of sadt a formal syouen for design.

The author has found the ese of the ierms sabjoctive and objealne to provide a cseful viewpoint in this regand. The tem objecrve is defincd az existing independent of tec nind, belonging to the sensible world. being observable or verifable especially by sciemife methods? Insofar as design is (at least in part) a function of the haman mind, there is obviously a subjoctive coespoecnt a it. The subjective aspects of design afe all poone io self-reference by their very natuor. Wowever, not all of design is subjoctive. Any

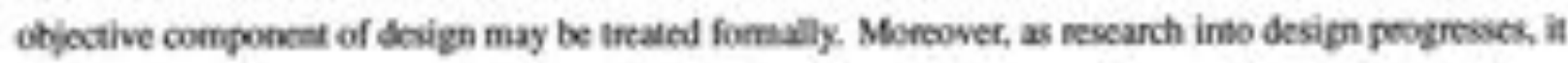
may be found that aspects of deulgn considered herebofore subjoctive can be trealed quile ebjectively.

\subsection{Design as an "Artificial" Science}

\subsubsection{The Scientific Approach}

A namber of eesearchers have suggesied necently that a moee "scikntific" appoach stould be empoyed in the schudy of enginoering design. Two ncecweethy examples of this point of view ane [11] and [31]. The argument for purouing sach a scientific approach generally procecds as follows:

- The objoctive of scicnce is to provide a pective and logical understanding of natural phenoencna.

- Deign as an endeavor is curnently not pectisely defined. and sends to be highly subjective. much as science was befoee the Renaissance.

- Therefore, those mechanisms thas provile procisice and stracture for science may also be able bo do so for design.

The relationhip betweba science and design theory will be discussod in this Soction. The authe postulaes that there is a part of desiga that can benefit the most froet an apposach based on logic rather thin scicnoe. Whereas logic is seen as a nocescay progenince of beth the "nanural" scichoes and design thecery, science and design theory themselves are sees as equals related through kgic. Because of the cgalinarian nowe

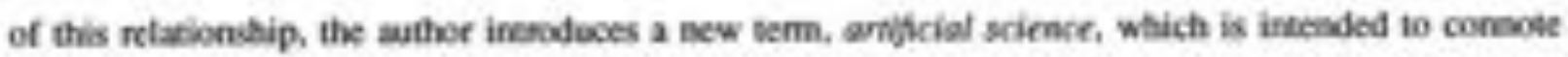

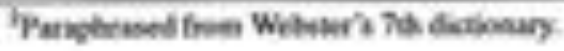


the foctal safure of design theory while distinguishing it froen the nataral sciences. The essence of this relationship is depictod graptically is Figure 5.1.

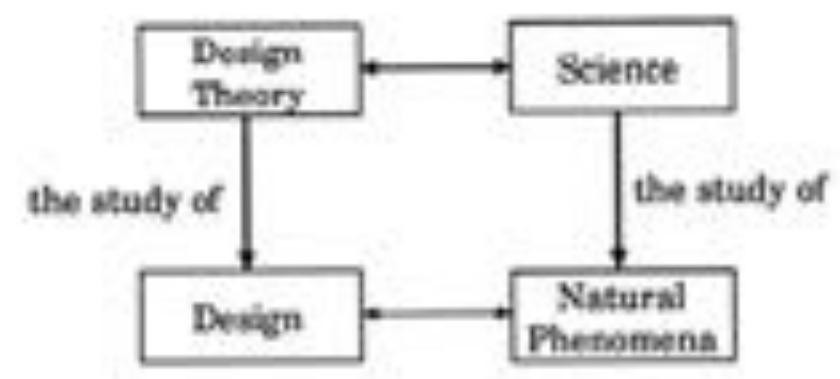

Fipure 5.1: Relationhip berween design theory and scilence.

The teclniques espoused by suppeenes of a sclentilic approach to design reseanch generally seck empirical daca about dexign (c.) $\mid 117,122,126,135$ D. The scientific method is wed as the basic methodology in soch projocts: observatices aee made of designers a work: then, foemal models are sough that can poedict (an least wo a degree) the beharior of designes when coedronted with particular situaticess. Soene call this kind of reseanch cegsibive desigs research, and the procedefe used is in essence the sare as that wad by scientists to imestigate autural phenomena.

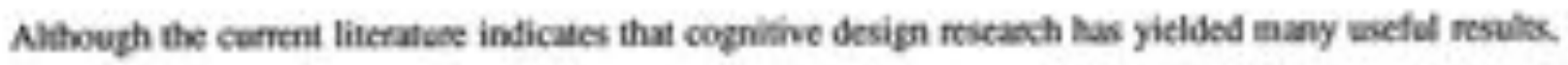
the wuthor viess such rescach as being tageted not at design per se, bat rater at the merial poocesses of the designer, and as sach tends to the subjoctive, This view has been espousod by at leat one major popoent ef new fandmental reseanch into desigs ( $(4)$. The distinction is imponant because statements about how designen thiek do net necessarily relate to design itself. We have staed earlier that mereal processes occur withia a self-referential system the mind5 and thas ate unprovable by convenbonal logk technigues. Wowever, these mental pocesses can be robonaliaed as scon as they ate extemalinod; that is. as scon as these mental processes boome marifesed outside the mind - be it in the foers of a CAD drawing, an english sentence, of a marthematical fomula - they kave the realm of the self-eefenerial mind and can be analynod logically so a geaser extent than if the designer's cognitive functions wese included.

In this ways, the asthor differentiares berween those parts of design that cannec (ourrently) be focmalinod. nancly the subjective meneal processes of designen, and those that cas (and should) be formalized. nanely all eutmalinations of those pocesses. We note that our intention is not to remove the ceeative. cogative components from desiga bet rather 10 provide the means by which to analyre the results of these 
processes in a logical maner, thas helping the designer to chaned hisfher inaginatice and creativity in dimectioes that will maxinise pevalts. Many of the best mathematicians and scientists theouphou hishory have been very cteative and inuitive people, and have used these characteristics in their work to great avantage. This should be the case in skxign as well. Alvo, formaliration of the non-metal segments of decign ean be beneficial to cognitive design rostachers by providing them with a yand-stick againe which to make obotrvations and conpare theories.

\subsubsection{Design Versus Natural Phenomena}

The scientife meshod is a trial and emor itchrique, the goal of which is the creation of nodels based en ebervations that let us undersand a given phenomenon. The kegical and mathentukical modelscreated by scientius bave provided excetlent lisonomisms to various notural phenomena. Basod ce these stcesses. it coold be argued that logie in sone way seflects an essential propenty of the universe. However, this proposal begs the question of whether the univene is deterministic [16] In order as avoid this consensious

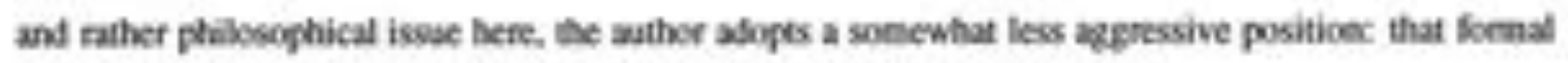
models appopoinste soese underlying structurt of the observed phencencnce.

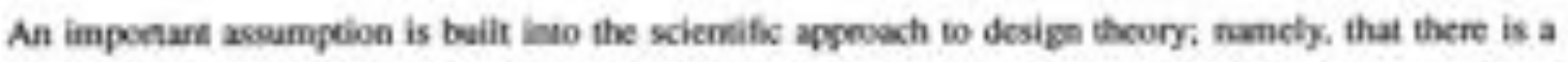
comespondense between đesign and natural phesenena, and that this comespondence allows nesearchers to treat design as a nafurd phenemenon. In cher woeks, the same iosenophiens are selevan to both desige and nafurd phencmena. The mither coetends that this assumpeion is misleading: we mabe our cave with the following argurien:

Design, unlike narural phencmena, is "coetrived" in that it is a poncly haman imention. While nature nay be considered as existing without asy action on the part of hemars, design is not independent of human beings; in fact, the designer is the only apent by which design is marifessed at al [14]

Also, the evoluticn of desiga has proceodod ever the years la a more of less ad-hoc mannet, responding not only wo the emergence of new scicntific and wotnological undentanding, but also to various sceislogical, cconomic and govemnteral pressures, mone of which can be said o be panicularly natural (in the seicreife senve of the wond).

It may be argood thas since the human mind is a nuurd phenomenon, peocesses that occur within the 
mind (such as design) shocld be considcosd likewise. The author argues against this position. There is no dependence of natural phenomena ce human beings. However, design mopains the exidence of the mind. This distingulshes design fruen natural phowomena.

Selerce has hat litle soccess in understanding the haman misd so far [155-157], mocth less success than it has had ia undentanding nabural phencmera such as gravity, naclear reactions, and DNA. One possible explanation is that the isomophisas that have socoessfully bect applied so narural phenomena ase not accurare with respect to the human mind, and becase design is a construct of the mind, we may say the same about desiga. If we cannot understand the mind, how can we understand desiga which is an invertion of the mind? The authee is forced wo coeclude. then. that it is inspropriate to theat design as a natural phencencnoe that can be studied scientifically. becase it is a mental process.

\subsubsection{The Kole of Design Theory}

Having aparently comerod ourselves in this way. we ane lest asking whether any fomalizationef dedign is possible at all. The solatice to this quandary lies in recognizing that wo bonot need the same ivomorphisens to apply to desiga as apply to natural pheachena. Because design is a mental prosess, it can benefit fom the same bogical thinkine that permits scientists, mathemaricians and logicians to solve problems moer complex than they couls if they hat only their intuiliso and creativity to guide then. Dut becauc design is net bound by the structure of nafure, we are froe to make of it whanever we choose.

Though relacively uncoesirained by nasure, decign theorids should nonetheless scek as formal and objec-

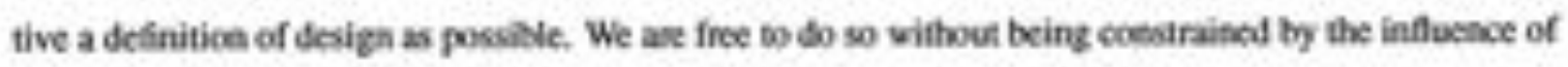
science because desige is not a natural phenomenon. No formal sysicm is relatod de-facto wo reallicy, it is the discovery of iscmorphisms betweca the format system and realiny tha makes in relevare. Any system for which as isoetsophisu wo a phensmenon can be found becomes a cantidate model than can be used within the scientific method. The use of logic is nouind becasese it is the only wool mankind has devised so far to seasce in a relisble and neperable way. Decign theory should thus depend on logic, but not on science, for ngor. Hence, the auther views design theory as a sibling, or equal, of the natural seicnesk. shaniag with them a dependency oe kgic (see Fipure 5.1)

This is not 60 sag that design is not melatod so earure at all. Ueally, the ultimate newlt of decign is an 
artifact havitg soate paysical esistence; thus it must relate to natuse in scme way. But this is whar design does, here we are concemed with what it is.

In summary, the author contends that design thecy should be concemod with finding logical systens that can fonmalioe design without necessarlly relying on the ivomorpeisms of the naoural seicnoes. In an effon to enphavine teis axtion, the auther introfuces the iem artificial science to describe design thoory: This tem has been chosen to dielinguish clearly berween design theary and the naparl sciesces while preserving the ilca of scme coenmonality between design and natural phenomead.

The author nowes that there is alrealy a bendency 10 consider design in some way artificial; for example, the teme spekesis is offen used bo descrite the methodical generation of a design artifact. even in coewereicnal design conents (c.g. I34). While syakes's is often taken rougbly to mean cratios, it has a connotation of actificiality thot is screrally missing it coetexts where conumion is used".

Since desigs is something thre begins in the human mind but ends in the real wodd, there afe scme appects of design thet logic cannot be espected to captuse on empirical groundk. hadtition to creativity, intuibson and cpirion, "facts" fron the real world canot be deall with using logic abone, in the same way as the atoenic petmises of the syllogism about Socrates in Chapter 3 cance be dealt with using logle alone; here is another fegion where eaturd phenomena influchce desigh, and where the coevereiconal scientific method may be used. Sill, there eanain many appects of design that ae candidates foe fomalixation through logik.

To this end, the auther postulates that a lopical sysicm to molel enpinceriag desiga can be achieved. The sysiem wowld be used to represent facts and 10 reasce about desipn. Theories about design and design infoenation may be derived within tho model and eventually sepponted of disproved by logical andysis. experimenrasion (l.e. applicasion of the theory to test situatioes, and observation of the resulting systems.

The derivation of a logical system for design as a artificial science is the principal pool of the asther's work. The first coecem is to idsutify tools of logic that provide good iomorghisms. in secking wach a system, a retum to first principles has been found necessary to limit empiricism, self-neference and the influence of the designer's metisal prosesses. The result of the wather's efforts in this regand is presented in Part III.

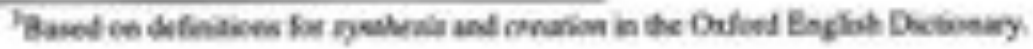




\subsection{Summary}

This Coppter has discussed the abranages and problems asseciated with the use of fomal sysiems in design

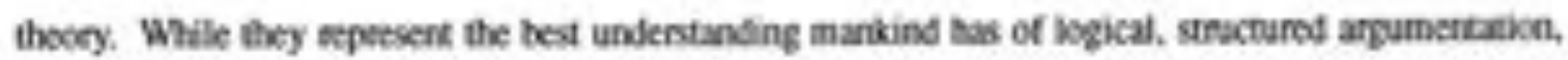
formal systems are ibherently liminot by Godel's Inownpleteness Theorem. Nonetheless, so superioe approach to systematic. formal rasceing exies, 50 in onder to maximine the degroe of figor in any amenpted fomsalization of design information, foenal systems should be considered an essential wool.

Furthemore, the author ianodeces the nem andidid sclence to describe design theory as a sibling of the natural sciences, shaing wis them a dependence on logic for formal tipor. It is unerascriable to eapect out undentanding of natural phenomena (the doensin of the matural sciences) w contritule wo cur undentanding of decign. because design is manifosted as a coestruct of the human mind nother than being a natural plenoenence independent of husan cognition. Althougt we lack a good anderstanding of the human mind, the carernallsations of cur thooght processes can, and should, be subjected so logical andysis. Sych andysis can idensify inocesiduencies that might otherwise escape detection. Furthermone. the formal secteiques of logic can help a desipner channel hisper creative and intuitive energies in dimctions mese lakely so lead so socecosful design solutions. 


\section{Chapter 6}

\section{Logical Solutions}

\subsection{Limiting Self-Reference in Design}

In procoting Sections, it has bech suggesied the it is posidie we construct a valid foenal systen for those parts of design that are independent of baman mental fanction. Such a sysuen stould be atle to deal not caly with specifie infomation reganding a panticular design antifact, but also with various degrees of abstract indormation that ane cqually essential to the design endeavee. Howevet, we mast impose a centin structure upon the systom to awodd self-reference. The structure is such that the tital system is cresposed of logical sub-systems of increasing degree of atouraction. Each sub-system is capable of neferring to ether, bower layen, bes noe wo isself, of 00 higher (more matrac) layens. This is in essence the solution sezgessed by Beatrand Russell to a lange class of paraboves in the originol derivaicons of classical set thoory [153) that arese due to self-reference. The resulting layered structure consists of ene layer for each degree of abstraction. th the general case, whese the domain of a begical system includes the entife univenes, an infinite number of layers would be neodod to capture all possible abstnctions. Fortunatidy. due to the mistively restrictod domain of desiga (with mepect is the genend case), and because each layer would have a distinst mearing in design (via the boenortism), a layerod sysacm of logie should be tractable.

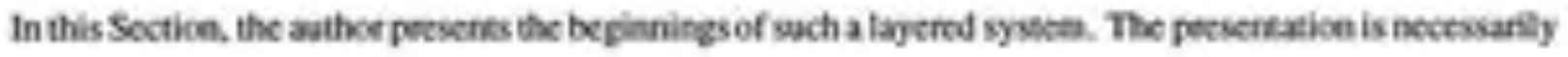


quite general. but it does soggest the oweralt strucenere of the sydom, and indicues how the varioes degrees of atranction are deliatited bured on the notion of anoiding self-efenenoce'. The seructure is depicied graphically in Figure 6.1. The relaticnstip berween the llybrid Model (HM) and the rest of the layered seructue is abo shown in the figure. HM is preserted in Pat III.

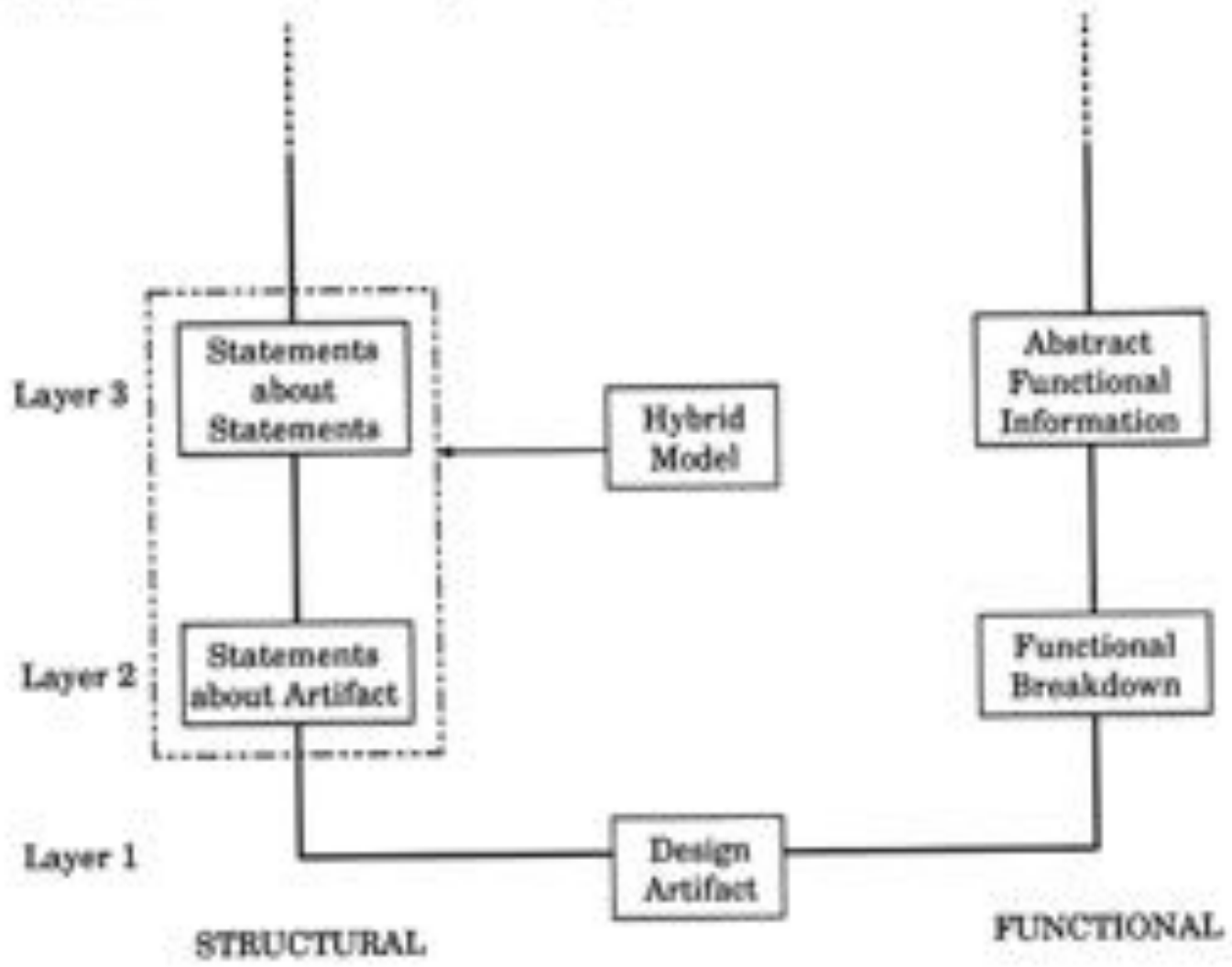

Figurt 6.1: Logkal stoucture for removal of self-reference

At the lowest (least abstract) level of the sywen, is the design artifact itself, this is the actual partobjoct that is the goul of a design process, an actud phrysical entity. We inmedinely divide the system into two sifferent but conplemenary beanches. On the one hand, there aee all the stakements that can be made about the antifat at ary instant in its existence for even befoee or furing its creabon), on the other hand. there ase all the axtions that afe roquind to create the artifact. 10 use it, 60 maincain it, efk. The separation is esseatially ene of sirnchare (description) verus fuection (poccofurt). The beanches are complementary in that they both relase wo the design antifact. The stoctural branch is static, time-independent and pescriptive, while the functiond beanch is dymamic, time-sependent and descripelive. Purthermore, the

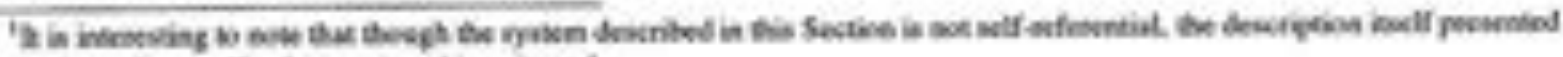

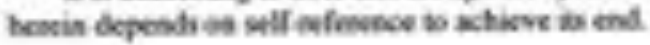


structural brach addresses the isose of what design is, whereas the fuxctional branch deals with the how of design's occurrence and procedare.

At higher levels of aburaction, the functional branch capures the design process used to create the antifact and icues of eognition by the devignet. Thue, the functional heranch mag eshibit self-reflerence. The structaral beanch exhivits no self-feference because it doss not consider the role of the designer. Thas in wis franework, we can idennyly and limir the effects of self-neference.

The stuctural branch eaptures the stake of infonnation pertaieing 40 a description of the artifact at various degrees of ahoraction. Since this description is independere of the actions that cassed the information so be discovend or generated, it is applicable uniformly throughost the desien process. Also, since the description is independent of the agents sespotsible for those actioses (the designers), it is also applicable wa any design process; that is, the information dcscription is independent of the design prosess. Thes, it is possible to centrol self-reference in the strucpural branch. HM, which is the heart of the author's work. is coetsined ertionly in the stuctural branch.

Each layer in the proposed system mabes suactents abou the proceding layer. thes is the case in both branches. Thus, Ex first tayer beyond the design antifact in the structural branch coetains stakencots. about the antifact, capturing concrete facts about it. The seoond layer coetains statemenks neganding the classificabion of these fact, and by exteswion. the dassification of different antifacts. The next layer fact Ahown in the figure) entains statements about different classification schemes and mecharisms.

Similarfy, in the functional branch, the first lager beyond the design aftifact contains fonctions provided by the antifact and a functional breabidown of the urtifact. The seoced layer contains actiors taken bo create (design or manufacture) the antifact. Theoe actions may be alloctid by the cognitive processes of the designet. The net higher level (not showi) corkaiss mort abstract informasion about those instructions. Cassification of actions would also occur in this layer, and can include jedgmental and insaitive femarks about the relative merit of those instructices. The next lovel (also not shown) would include statements used to meason about the clascifcacions and would include issues of decision making and negotiation between designers. This information would be used in the generation of diElerent design methodologios. their analysis and comparison.

The peccess of atbination is used in both branches wo move from one layer to the next. Clearly, the abstraction could continec ad iofnihaw, generating inmamerable layex. However, the kinds of stueenents 
captured by these layers would quickly becoene 50 abotract as 00 be entirely meaningless. As this time.

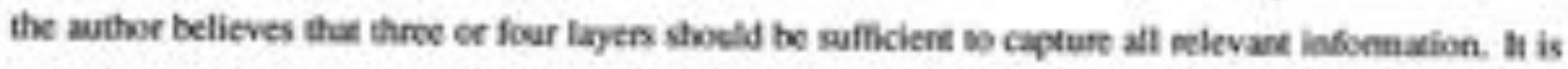
also noted that this layerd stucture can be usefal in the generation of desien tawonomies by provising a critenos for separaing statements (i.e. infommation) basod on the depree of alsiraction usod.

\subsection{Categorization of Design Aspects}

It response bo the lack of formal ieminology and auonomy for design and desige thoory, the author proposes a mechaniam that can assist in the erganizatice of relevant notions and their cocresponling temins. The mechaniven proposed berein arose froat the author's cosoiderition of matry appocts of design, only one of which is merisionod here, by way of at exasple.

Keirouz ef al [122] discuss the differences betweten variational and panmetric modeling from the point of view of constrint savisfaction in conceptual design, The cwrren author coesidered bow best no categceive the cilod work: it did mot belong strictly in any one of the three areas anenticend (moseling, constrint theory and coeceptual design) but soemod to nelate wo the three logether.

This kind of tightly interweven depradency between various aspects of design is indicative of the high degree of complexity requifed to accurately model it. Considention of each of the aspects alone is not sufficient because a large puet of the complexity arises form the selatiomhifs that esist betwoen then. The wuther therefoes sosght some mochanism than could nepesent the varioss aspects of design as individual componests while also capturing the relationships that esist betwoen them. The mechanion is intended primarily as a conceptal tool, an aid to simulake clear thinking about a potentially confasing pooblem.

The author's rescarch sugessied that in a real deign process, thene as a rumber of different, faifly independent aspects tha internelate. Due to the tichness and complexity of these reluxionships, a multidimensional apposch seemed appopeiate.

The author thus proposes the use of a design spoce coenponed of eethogonal axes. Each axis ropresents an independent avpect of devign. In this syctem. different relasonships, approaches and techniques can be clascifiod and compared. A particular selationhip can to mprosented as a point, line or negion in the design space. The authee has bdentified foer onthogenal aspects of design artifact modeling (the Aaxis). 
behavioral modeling (the It-axis, mota-modeling (the $\mathrm{K}$-axis), and modet implementations (the laxik). Each aspect is assigned to an axis in the space, exth of which is discussed brictly below. Figue 6.2 represents the four fimensions of the design space as two threc-dimensional spaces sharing two axes, and inclades a shaded aea representative of the "locus" of the work described in [122].

\subsubsection{Artifact Modeling}

The elrimate goal of a design process is the production of an antifact of probuct. Thus, one appect of design is the abliticy to seare in precise terms the nasure of the antifact. Hat is, the Boncration of a model of the antifact icself. Information from this model is evertually usod in a number of oher ateas (analysis. matufactaring, etc).

Foe this ravon, onc axis in the design space is allocaled for Scoign artifact modeling lechriques, inclading the physical aspects and the physical relationhipe betwoen components in the artifact. Variationd and parametric modeling, as well as varbus solid nodeling techriques, would all be represented on this axis. In Figure 6.2. artifact modeling is nepresented by the A-axis.

It is intenesting to consider the fole of condrairs in antifact modeling. Are constraints, vis-a-vis constrain satisfaction, a eecessany part of artifact modeling? Ot ase they eswntially orthogonal wo antifact modelieg?

There are engoing efforts in the field to investigate "ocnstraine-bused desig" from points of view ranging from knowlodge-based systens [23,55] to aliemale parancierixation schemes [72, 158] and consiraietbased design [57]. These efforts have all had at least some suocess is embedding constraints into ocher deslign appects. However, ecnstrint theory is in the mos peagmatic seroe an andytic iochrique and nos a modeling technique: it permits the mathematical study of the capability of an antifact to provide a given functionality [63] (this noben is fiscusied in more detail in the nest Section). The author recognines that constraints can also be esed bo analyze and stufy modeling tochniques but in such cases, the conoraines apdy to the model, not bo the antifact being modeled, and so must be reganded soparately. The design space being discused in this Section is meant to study desigr, hence, constrains ane not imvolved in the anifact modeling axis. 

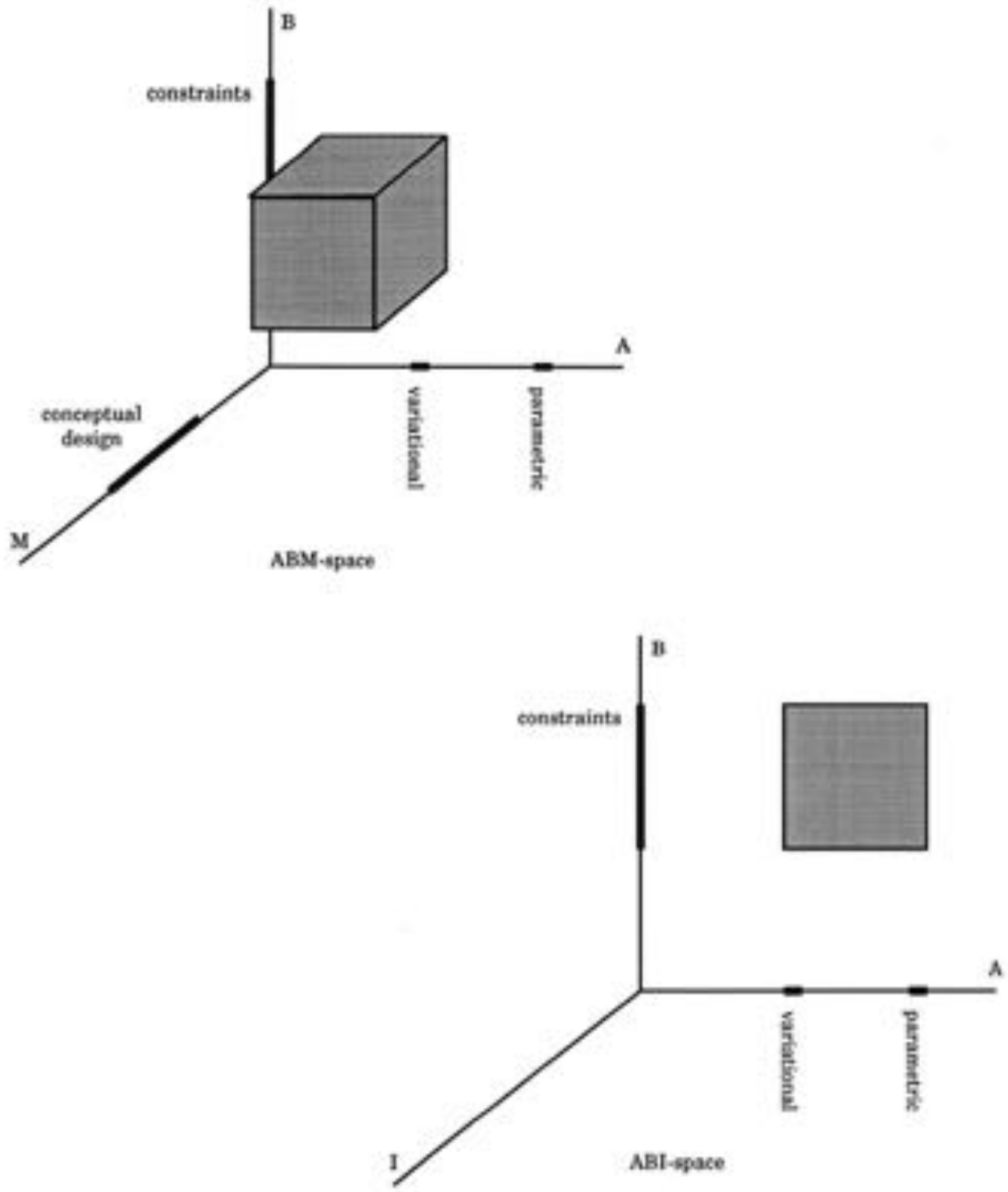

Figure 6.2: Griphical represencielion of the AD Design Space as two 3D spaces 


\subsubsection{Behavioral Modeling}

Behavional modeling captess the other side of the aftifact modeling oin. This aspect of design is concemod with modeling the respone of the antifar to stimati provided to it from iss operating emvimument.

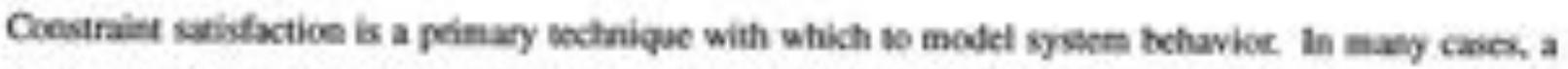
design problem begins with the specification of some objoctive function to be met by a desigh. This objective function is derived froa isves cenceming the enviroment within which the design is is function, and tabes the foen of a censtraire. Other comstrints, inclufing those intemal to the artifact itself. are uswally derived in some fachion from the objotive function.

Constraints pemit the creanion of mastematical models of anifact behaviot. Mathonsical modeling of sysens (eg. finite elemest or kinenaric analysis) is therefore also included in this aspect of design. Optimization and simulasion based on the mathematical representation of behavioe are also iscludod.

Oestraints capture the relationships between form and function, and abo between the antibat and the envionment within which be artifact is to function. They bus represent the link between an anifacts structural model, which is usually represented as being isolated from its emviminent, and the rest of the world lie which it is intendod of function.

A second axis of the design space is wed to represcre behavional modeling, and is labelled the B-axis in Figure 6.2 .

\subsubsection{Desiga Evolution, or Meta-Modeling}

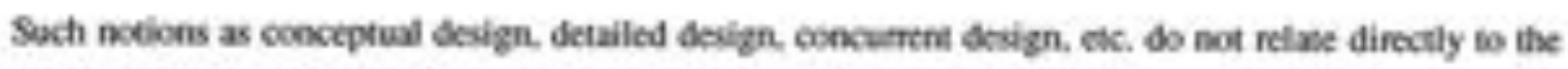

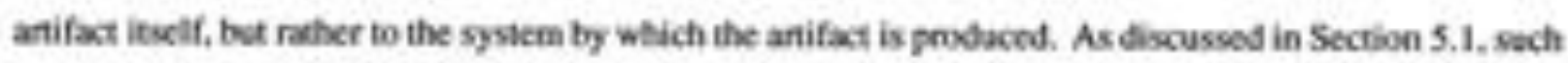
notions exist at a different level of anaraction than those of artifact and behavior modeling. By treating

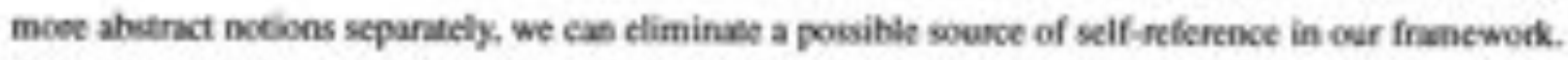

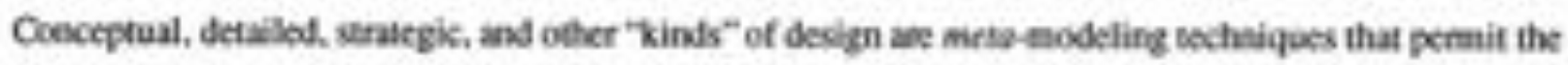
study of the roodels themiclves, rather than of the thing thes is modelod (the design anifact?

Thus, a thind axis is needed no mepesent dhese meta modelieg notions of design theory. In Figure 6.2, meta-modelling information is mpresented by the $w$-axis. 


\section{2 .4 Implementations}

In Section 4.3, we indiened that a distinct separation shoeld evist between models of designs and desipn prooesses, and how we implement those models. It is appopriate then so propose a founh wis in the design space to repesene the implementations of the appects of sesign represented by the other axes. Computer implementations of fomal modets is one composent of this axis, but implementations need not be dependene oe the use of compuien. Whenever an idea, formalized or noe, is inplemened in any way, a nomber of cher hsues that are implementation specific - issues thas are not impontant at the nodeling level - mast be corcidered. All these implementation issues and the lechnigues we use to handle them are represented along the fourth axis of the design space. We have labelled the las asis as the Iraxis in Figure 6.2.

Insclar as cenpules are concemol, all lisues rganding software desipn, testing and usage would be ropresentod on the implemertation axis; these inclode navers reganding dacaboses, compuner languages, graphlics, etc.

\subsubsection{The Example, Revisited}

By way of example. Figure 6.2 shows the rgices eccupied by the work in [122], acelionod at the bepinning of teis Section. We may quantify the cited work as a volume in the design spece bounded by the design aspects marked on the axes: parametric and variationd modeline conceptual design, and constraint satisfaction (also labelled in Figure 6.2]), and since the work does not discess lisues of implenentation, it appears as a two-dimensional region in the ABI-space.

The quartificaion that is prosible through the use of the devign space can perait a new degree of orgavixation in the work of desiga worachers. Its graphical mpoesetation pemaits easy visualization of the relationships that exkat between different rescach efforts. It could be usod io organize individual rescasch projocts within large groaps and indicale regiens where mort wotk is neoded of where different projects

overlap. th asy also find use in the oeganization of engincering corporations and coedrolling/rtgulasory bodies by cleacly marking the boundaries of the aceas of inflence of each body. Tho dovign spoce can cren be usod bo orgavine coeferences and other meetings by perminting visual identification of ancas covered by each presented wok of repesenesive group. 


\subsubsection{Relationship to the Layered Structure}

There is a refalionstip between the layered sructure in Figure 6.1 and the design space in Figure 6.2. The layered itructure separates Segnees of absination is design, whenas the design space separates erthogenal aspects of desige. The A (antifact modeling) and B (behavioral modeling) axes of the design space repersent the structural and functiond branches of the layend stracture respectively. Alwo, the K-axis (meta-modeling) capteres the increasing degroe of abstraction that ocours thmogh the layered structurt. Since the layenod structure does not deal with implemertation issues, thene is no comspoedence with the I-axis.

Thenefore, bolh the layered stuctare and the design space captuse the sante basic philosophical notions. albeit foom different peints of viow.

\subsection{Summary}

The author has suggested two possible sclutions for addressing problens in design and sexign theory caused by logical inconsistency. The first is a logical layened senctere the permits the clear distinction of different degrocs of abotraction (Section 6,1). Being able to classify statements made about design acconding to theif degrece of abstraction. wo may betier avold circular and self-efeferential argancrits that

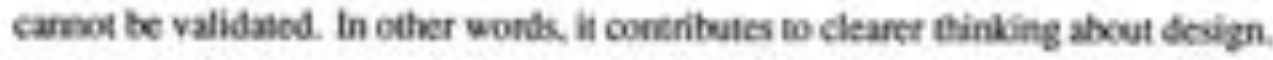

Secondly, the design spoce descriled in Sectice 6.2 permits the vioualizabon of the relanionshipr effered by various approaches and iochniques in devign and design theory aloeng foer erthegenal (independeni) metics: artifact modeling, behaviond nodeling, meta-modeling, and aodel implementalion. Again, the principal goal is 60 clarefy the reiationships inherent in cur usderstanding of \&esizn so that we may shady and improve that understanding 


\section{Chapter 7}

\section{Discussion}

This Pan of the auther's work has covered a fairly wide fange of vopics, but the enderlying peilosophic rotions ane fow and distinct. The gool of this sunmary is to corvolidase the manten presenied above.

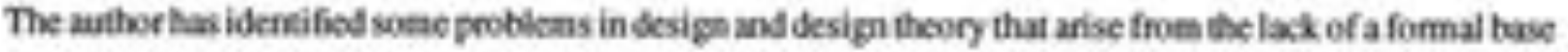
spoen which rigorous understanding can be developed. The changing. growing nabure of design is in part respensible foe the lack of accunte taxonomies of desigs componems, notions, methodslogies, etc. The

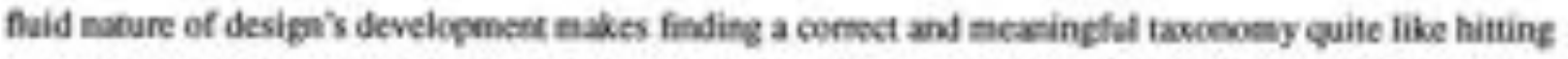
a anoving target. The nes-logical ad-koc nahure of the coolution of design is also to blante. frs relatively artitrary development has led to the inerofuction into commos usape of vagucly andfor incorristently defined ececepts and tenns. III-defined clawsification sysems for desigh artifacts, coenponcnts, systems, elc. have hampered the generatioe of apeopriaes bools with which decign can be stodied in an abotract scnse. Subjectivity introduced by considenations of the derigner's nole in design has introduced self. sefctence, which in tum leads to incosesident design thoorice. These shortcomings have hamod car ahility to communicate and have spawned incompatibilities between the various appects of design, leading to so-called "lislands of audomation". The inability to communicate properly has also affected cur ability wo teach desigh, and thus perpenates the inooneidencies.

Enpirical stodies are unlikely wo lead so a mote sciensife understanding of desiga because the influence of self-efefence within such fratheworks carnos be dealt with. Of courve, existing design thoories and methodologies can be valuahle in guifing our search foe a logieal design thoory, bat we should not be 
surprised whes inconsistotcies in oer curreat undentanding are found.

Self-mefenence can be minimized only by forming logical syacms for design that do not inclute the subjective, cognitive functions of the desigrer, Logic offers as mavy tochniques that can be used in this ngand. These techniques mest be diligently aplied throughost our eflosk, much as they bave been in the fomalization of science.

Theories of design can be reganded as being either functional of sinuctural in naturt. Functional theories describe artifacts froes the poiet of view of the functions they porvide and the actions noeded wo create then. These secm most prone to self-eference becasest the actions can be traced to the cogritive functions of the designet. Stowctural approaches can result in formal theories without self-reference: such thoorics take the fom of prescriptive infortakive descriptioes of desige antifocts a various degnes of abstraction.

Some may argue that the intersive use of logic in desigacan sifle sach intangiblo and qualitative things as creativity, epinion, intuition and judgnent. The author maintains that this is not the case, Logic des not squekch creativity and intvition, but rather chanels it, helping wo kecp the designer from making crrors that would adversely aflact profuctivify and efficicacy. It helps a person have saore infoemed opinions and make more educaled judgnents.

Tree informal, concepeual fools have been inrodaced. These sools afe meart so clarify and stuby the postulated logical structuse of desige. The notion of design as an artificlai science is presented so reconcile the differences between the "natural" sciences and design theory, and to present a poirtef view that pernits

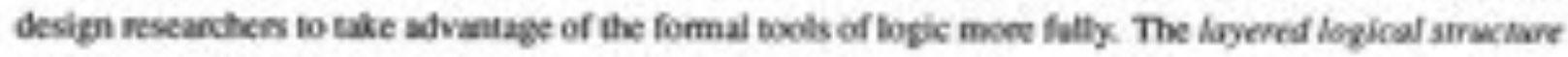
presenaed ia Section 6.1 permits the modularization of design by degrees of aboraction. It allows for the idensification and subsequent elimination of scene eccumences of sely-reference from design theorys and may be useful in the generation of desipn tawonoenics. Finally. the notion of a design spoce permits the dassification of the varioss tochniques available no designers, and assists in the erganication of the eflocts of design sevearchers and theorists.

The insention in this Pan has been is introduce in a relatively informal but detailled way the domain of the wishor's work. Having established this definitional framewexk, we may now proceed to detailed considerabons regading the sfoctaring of Acsign infoenation. 


\section{Part III}

\section{FORMALIZING DESIGN INFORMATION}




\section{Chapter 8}

\section{Introduction}

This Pan of the asthor's wok is devolod to an examination of devign infoenasion with the aim of formalizing iss structese. This is dose by peopositg a formal system that felies en axionarie set theop fot internal consistency. The suther calls the revulting model the Hyorid Modd' (OMM) of design infomation. The engin of be name "Hybrid aodel" is in the author"s chipinal reseanch in coenbiring object-ericated data models [159] with hypersest [160], hence the use of "hybrd". Since then. HM has evolvod into an entiely differem kind of model.

In keeping with the observatices nade in Section 6.1 reganding the limining of self-reference through the use of logical layers of increasheg abstraction, we will persent 14M in two Chapters. Finst, mastens melating wactual design inbonasion will be dealt with in Chaper $\$$. then, the organication of that indonnation will be dealt with in Chapter to.

As well, it was indicated in Section 6.1 that a distinct scparabon between stractural and fanctional descripeicens of desien artifacts lends itself well to the contmol of self-reference, an indinctively haman action which has been argued to be detrimental 60 the developonent ef rigopous design theorice. This implies a separation berween design information and processes that manipulabe or ctherwise use that indomaabon. It has aleady been supsested $[7,161,162]$ that design infomation can be considered separate from the engincering design process.

Finally, the author coetends that a good undentanding of design infornation musf presedr amy feul 
understanding of the sedign process itself. This issue will be discussed in Section 8.1, and motivates the cenknl thesis of this work: the search foe a fonnd theory of design inkoentibon.

\subsection{Modeling the Design Process}

In this Scction. the auther persents a model of the design process with the inerision of spporing the hypochesis mepanding the scparaicn of design informatice and processes. It is presentod only so the exicrt that in provides a reference point for the developnent of HM, and brings wo light several imponare aspocts of the design poocess thar have affecued the development of HM. The model regauss the design process

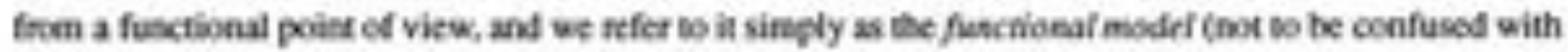
the functional branch in figare 6,1).

We begin by maling the relusively trivial statement of a generic mxhematical fanction, nanely:

$$
y=f(x) \text {. }
$$

Hork. $f$ is some furction that maps an input valoe fepesensed by the variable $x$ to some outpot value mepresented by the variable ys indeed, $y$ and $f(z)$ are ifentical. Now, from the point of view of design. we rewrite this equation as:

$$
S=\mathbb{A}(P)
$$

$P$ nepresents a design problem, $S$ iss sobution and $d$ the design process. We enay state thix in words as:

There is a design process shaf operates of a particular desigs problew and results is a carresponding

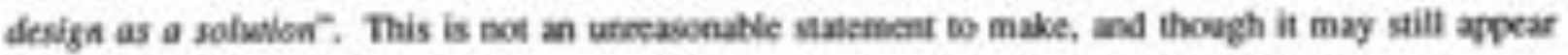
trivial, it does camy scene important implicasions:

Cearly, the solution depends on tho pooblem othe ousfut is the dependent variable). Also, as staicd above. $S$ and $d(P)$ are identical.

Fom a parely mathersatical point of view, ene nay be inclined to stop bere. But there is mone than cene 
way to decign a certain eneity. That is, given a particular design protiem, there anay be more than cee design process of thut can perwide equally accepouble solutices. Selection of a design process depends at Ieast in part on the kinds of information about the problem that are avaliable to the designer. (It would also depend en optimination considerations, as weil as on the more subjective preferences and judgments of the desiger.)

If the input is badly or insoncetly definod or specified. then selection of an appoopriabe solution function

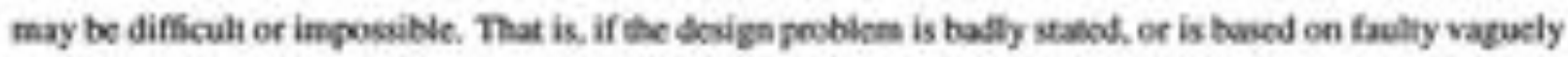
or verboscly presened inbormation. then the selection of a design process is prose to error (cince, as is

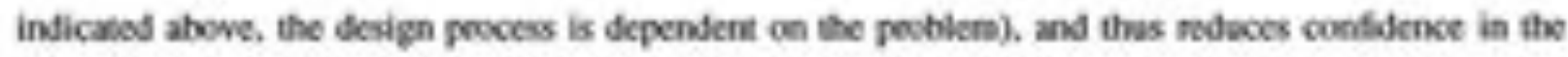
sciution. Thenfore, the pooblem must be ciearly understood and poecisely defined before a solution process can be selected and applied.

There is another issue that is an essertial ecenponcet of almost cvery noe-erivial dexign task; iteration. That is, a (possibly dynanically chunging) desiga pocess will be applied heratively to a design podelem in enfer so reach a final solution. We can sepeesent this in oer mathematical notation by;

$$
S_{i+1}=d\left[S_{i}+P\right) \text {. }
$$

For each iferation $i+1$, the design process $d$ is applied wo the proelem plus the seluticen, such as it exises. at ieration i. Put another way, the solation $a$ ineration $i+1$ is bused on both the poblem aed the ith solution. Whoos inchading the solution at heration i in the azument bo the desipn function. correcrgence wculd never occur. So, af each iteration in a design sycle, the existing - thoegh possilky inconplete and/or incorrect - solution is used to drive the nest ineration of the design grcle. The essential cbeervatioe here is the "superpesition" of the pooblem with the ith solusion: comespendingly, the problem and the solutice must be represcetable in a compatible way or the ineration process cannot proceed.

In summary, the functional model provifes two inponart indighes into be fequifemenss that must be net by a formal sysem for design infontation:

- a formal understanding of design state infomation is necessary bofore the decign poocess can be successfully formalizod to any signi ficant degree 6.e. desiga stake informatice is independent of the 
design process' $\mathrm{x}$

- the organization of information is selevas both for the problem definition asd the selution, and any

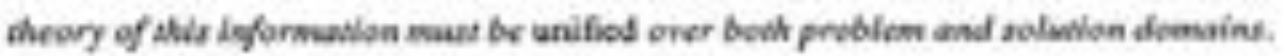

This approach diflen from that taken by other researchers. Suh [31] suses design problems in temis of functional requiremenes to be met by sucoesdel candifate designe, and solutions are stated in tenns of parametric representatioes of variables. Anocer appoach is tuen in by Yoohikawa [39], who defines two separale spaces = a function space and an attribule space - and exch of the devign problem and solution are defined in tems of one of these spaces only. These apposctes, attong ethers, are similar in that both

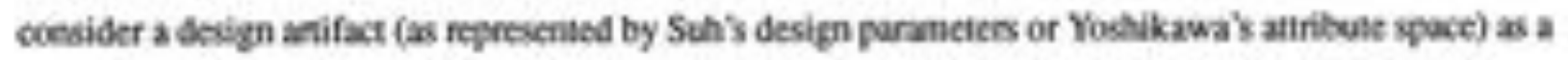
separate entity from the problem that cassod if to be designed (the fanctiond requirements or space)

This dual reprovetasion of design infomation by functions on the ene hand and paraneters on the other makes unifod nepresentation of sesign pooblons and solutions moct more difficult. As well, it intmouces coupling between the foen of the repecsentation of information and the design posesses that ue this informatice. la its faver, such a separation of the domains of functional noguincments and peysical parancter is beneficial froe a conceptual poin of view, pennining modularizasion of the task into staller segments that can be shudied individually. However, it can alko lead to a divergence at the theortic level that will prevent find integration of these domains ins a single, globul theory. Also, in does not address the dependence of iteration on the successful combination of information reganding both provelems and partial solutions.

The appooach presened hereln by the fanctional nodel is superior because it simplifies the masagemene and erganization of design as an endeavot. In an herative process such as design, the camulative information gescrated froes the heration is a essential coesponere of finding a cornoct solution. In onder to merge the accumblatod information with the desigs proteten for the inerition to continue, a unjfed mepesentation of both froblem and solation mest exist. The functional model of dosign mairtains the integrity of pooblem and solutice spocification while dividing the pooblem along a different and moet imponant boundary between static, passive informaticn and dynamic, active fanctions thas manform the ieformation.

The author also notes thas a number of edier reseanches hwe supponed the notion of separating rep- 
resentation of infoenasion from pocesses affocting that infornation including $[14,41,42,8]$, 163$]$ of particular interest is Favel's wok [41], which sugests that the relation

$$
\text { [activity }(n) \text {, Erbodimont }(n)) \rightarrow \text { Activity }(n+1)
$$

is represertachve of the design process. An Activity (i) is some componcent prosess of the everall desiga process and an Enbodineert. (1) is the physical nanifestarion of the result of the completion ef an activity. It is inceresting to note the shift in point of view between the aubor's model and that of Pravel. The latter is buod en the notion that given some iritial decign activity, the neselts of that activity drive the selection and execution of ether activities. The fomer is based on the notion than an initial embodiment (in Favel's temas) drives the selectioe and eacotion of activities that lead oo oher embodienents.

The author maintains the functional model as presensed above becasse of the observation that reliable.

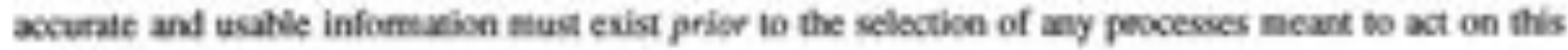
Eformation: that ik, the emptasis should be placed on infonasion as the dring foce behind a design enterprise.

Fawel reacons in detait en the role of various kinds of activibes that are relevant bo design, withoet Ewelling os the nature of the embodiments, His results are quite clean and elegant: this encoerapes the author to believe that the separation of design iaformatice froth design actions is net caly appropriate, bet necessary if design theory is ever to medt whth success.

\subsection{Basic Structures and Concepts}

\subsubsection{Basic Aim of HM}

\subsubsection{A Prescriptive, Axiomatic Approach}

The aim of HM is to provide a prescriptive, asiomatic thoory of the irfoenation peesent during the course of a design. Natunlly, only infomacion relovant bo a porticular design takk is considered, thus rectricting the application demain significastly. This restiction plags an important pole in the developenent of HM: this is discussed below. 
HM is prescriptive in the it prescribes a language foe the specification of information foe a design ask. The term is not used to pescribe methodologies that should be condidered noms (sometimes called a normative appooch). Civen the nole of humanovgtition in desigh, the asther believes that the best results can be achieved by a rymbiatic nelvisonhip between the designer's innate capabilities fincluding such intatgibles as jodgrent, entativity and intuition) and some mort formal logical system.

The term prescriprive is usod to indicatio that HM is a system that lics cutside the actual thoegh processes of the sesigner, that is. it lies within an objoctive, logical domain. The auther corviders this a more reasonable objective than that of the descriprive school $[11$, which secks so quartify and formalixe the actual cognitive functions (i.e. mental conent and processes) of the desigrer.

HM is ariematic in that if elies ce axiomatic set theory as its foundation. The author's ieitial aesrapts sosght a formalixation based en existing insomation managenent parafigms (object orientation and hypertest in particulark, but the lack of exiding formalization is these fidds was found to be insumours. Able. Oeject orientation is ofien neferrod to moee as a philosopliy or point of view than an actual formal paraligm [27, 164]; the status of hypertext is even more ienows [143, $160 \%$ it becane nocessary bo retum os mote basic fies principles, and it was during the author's study of symbolic logic that asionatic set theory presentod the sectsany iscencephisens upon which is base HM.

Aviomatic set thoory has taken on various forns [1, 16, 153\}, but every form is based oe the classical theory develoged by Zermelo and Fraenket $[80]$ and which is generally referred to as ZF set theory, or jugt ZF. This comention is adoped in the sequel. for brevily's sake. ZF requises celly the predicane calculus and is thus derived purely from logic, without any extn-logikal or other enpirical influences.

$W^{2}$ deals with groups of completely genernl entities: a group of entities is called a set. The theory formalizes the nuoure of sets 10 such a degree as bo permit the derivation of almos all the classical branches of mathematics and logic, including arithenetic, algebra and calculus [153], The most ileteresitg implication of set theory as far as the author is concemed meands considency of theories that aee supersets

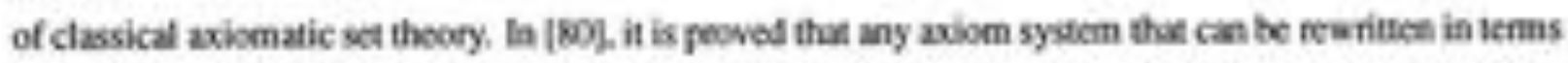
of ZF withoat intocducing any new abomic statemerks, quantifies of coenectives, is consistenk insofar as ZF is coesistend). In ZF, the primitives are $=$ and $\epsilon$ : cormectives are binary ogerators such as $n$ and $U:$ and the quetifien ase $V$ and 3 . As will be soen. this coesisency criterion is satisfied by MM. This mears that we know at once that HM is no less consictent than ZF, 


\subsubsection{Universe of Diveourse and Design Fintities}

The sem anlverse of discourse denotes the overall domain within which all interesting argamens aft mace. The entities containod within the universe of discourse comprise a complete vocabulary.

In this wotk, the univeres of disooune is the of design isformation; that is, the specification of of stanement of facts about - a design problem and the various coespoents and aspects of its welution, Withous censideration so any peocesses required is generate that solution. Within this mivene of discounc. the encities of relevance are whatever design entities ane arablable 10 the desigact in onder that helshe way fulfill the tack as hand. This greally restricts the space of posible eneities (as compared to, for example. Z. where any inem at all may be censdered so fall within the univene of discourse it is exactly because of the specific nature of the entisies involvod bat moch meer can be said about them than is nomally

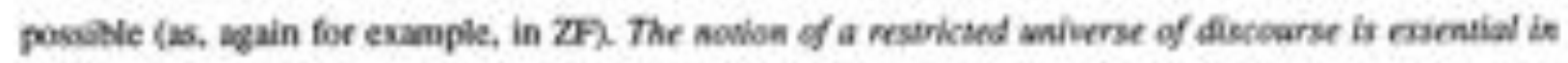
onder so be able ao derine $H M$ ar ail.

The ashor insomally defines a drsign curify is HM as some real-world stucture that is meanirgful froe a design point of view. This anit nood not be physically realisalele per se, it can be a purely conceptud item, such as a enn of a finile element progran or a manufacturing process plan. th can alwo be a frature. in that threads, holes, fillets, ete, are also design entities. HM deals, then, with the formalizacion of devign entities. In the Sections following, the exas fomaliration is sabd and discussed.

\subsubsection{Theory of Logical Types and Set Theory}

In 27, if a universe of Siscourse consisting of alt the posellele sets is considered, it is very easy bo gescrale a number of parndoses that casse the thoory bo bocuene inconsistent [80, 153]. A namber of schemes have been sugpestod over the yeans to svod these parabowes. Two of the classical approsches are the type-boortic approach, and the approach of class-inclusion

Oass inclusion assames a univene of discourse containing both sets and "classes", the latier being collections of sets (nos sess of sets?. The vesulting theories are quibe powerful, but send to hide some of the feanures of set thoory that the author consibces important foe design. The type-eneoretic approach, en the cher hand, vends wo be more explicit, but mose cemplicanod o manage as well. 
In a type-thecetic set theory, logical paradoxes are soidod by nestricting the kinds of individuals that can exid in various sets. At the lowest level in the cype-thooretic apgoosch exist the individuals in the univere of discourse and the attribuies that can be prodicalod en then (i.e. acted on by functions). At the next higher level exist sets (collextions of individuals) and the antributes that $\mathrm{cm}$ act cen these sets and en individuals. At the 3rd level exist sets of sets and the astributes the are poodicable en sets of sets and entities at bower levelc: and so forth. There ant an infinile number of levels.

Furthennoer, equatioes in a type-thoorese sysuem cannot mix predicates foum different levels ad -koc, but oely according to the following rules:

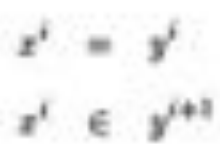

where i represents the level of an entity. The finst rule sexes that entities that ane equal mast exis an the sume logical level; Le, they must be, for exanple, both sets, ee both sets of sets. The second mile stabes that if ose ineat $(x)$ is a menber of another $(9 x$ then the fomer must be one logical level lowet than the lante. Dus, if we consider that (a) $x$ is a set. and (b) that $x \in g$, then the mules of type theory tell us that y must beloeg wo the level coetaining sets of sets (since $x$ is itself a sect).

The problem with the type-theoetic apporoch is that the bookkopping required to distinguish between the various levels complicases the notation. Fracnitel's sobation is 60 abd an axiom (the axiom of replacement) that embeds the conctpt of logical types, leaving the axiom which defines ststs (the axiom of separabion) uncuched. Zennelio's (and Suppes) solubion embeds the concepe of logical types into the axiom of

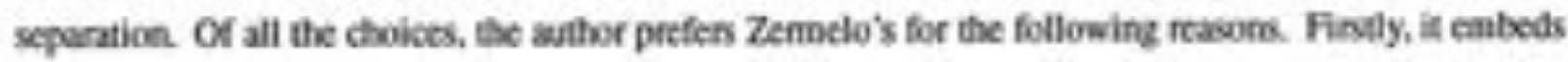
all necessary information without unsecessany adtitioes ss the nember of avioms or to the notaion. Secondly, in the universe of discoune of design information, as will be seen only a very few levels of logical types ase needed, and distingaishing betwetn their elentents is relivively easy: in seems wnocescary

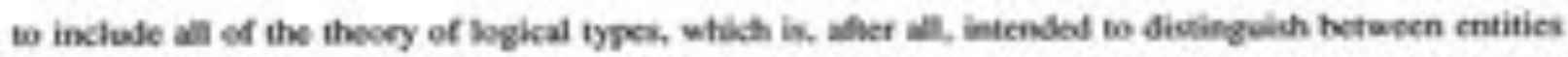
that would be difficull wo differentive etherwise. Thirdly. and most inportandy from oer peirit of view, Ae Zemelo solution flows quibe naturally from design coesiderationes and is a nabural forma of expressice 
of types of infomation nelevant to design.

\subsubsection{Fundamental Structures and lsomorphisms}

The fundanental logical structure in HM is an ebject. An object capeures a urit of information that is mexeingful to a dedigner. Tus, an objoct is the formal representasion in HM of the informal notion of a Sckign entity. Sess will be used no represent objocts. The fendamental isomorphisen of HM, then, is thas a design entity comespeds wo an ebjoct for seth. The isomoghisn is not part of HM itself for ZF foe than mather). but is an extrabogical relationahip Siscemed by the author between design and format logic., and which gives meaning to the formal syatem (HM) from the point of view of design.

A bolt a tress, an aiplant, a lole and a nu of a finibe element poogram would all be repesented by objects. Otjects nay "contain" other objocts (this is disossed below). The encity represented by an object nood nos be physically realisable (fer example, a bole or a fillet), thes it includes feotares [42,53]. Otyocts may repesent machining and other manufacturing prosesues.

The use of objocts is importan becase it perntits encapsularion of infomation. Le., the discreticatice of a quantity of information into meaningful stractures that can be treated as sitgle units. Encapoulation leads to the constructioe of anfered colloctioss of informasion. This can greanly simplify manipulation of the information. For example, the alphabet is a structurt coetaining the ondered sequence of writien exprestions of the phonemes that compose the English latguage. Similarly, ascrew is an onderod collection of infomaxion that models a devise used in the real world as a kind of fastener.

Let ine set of all objects be denoted by $O$, and $i e t, X, Y, Z$ be members of this set (i.e. individual objects).

Axiom 1 (Ueiformity of Structure) AN desige entilies are represened by objecrs.

Axiom 2 (Unigeneness of Object Identifiers) A unique object has a usique identifiex.

Althouph the relevance of axion 2 may soes at fint glance to be trivial, these is also a mote busic. philosphical concem. We must be ahle wo identify any design entily if we are bo use in. The peocess of identification is cisential in distinguisting between entities in the universe of discoscse. The manifestasion of the process of identifexion is the anachmen of an identifier to an entity. Sinoe cbjects model design entities directly, we miut also be able to identify objects. 
A1 a moee practical level, an objoct is a conceposal soof that permits us to abotract, infer, and dofuce inbormation ahost design cetitios. and we classify then by their concepoual definirbons.

One of the principal concems in any theory of infomstson is that of coscring or erganizing the iefsmation. That is, the defnitice of melationships between entities is of primary importance. It is a means of naking aplicir infomation that would be otherwise only inpilicit within a collection of duen In HM, this is dose with relations and fanctions as defined is $Z$.

A relation is a statement that defines a relationship between entities. Civen a collection of sets $(A, B, C, \ldots)$, a relation $R$ applied so the colloction ylelds a set of ordered sequences $(a, b, C, \ldots)$ such that a $\in A$, $b \in B$ and $s 0$ on. The ondered sequence is eften used as a repesereative notasion for the relasion itself. That ik $(x, y)$ (when $z \in A$ and $y \in B$ ) represenss all onderod pairs arising from the application of some nelation $R$ on two sets $A$ and $B$.

A function is defined the same as a relation, with the added restriction that the relation $R$ can map a single value of $x \in A$ wo exactly one member of $y \in R$. Functions ate oflen wieven $f: X-Y$ and are read $f$ is a function that naps the monbers of set $X$ to the nombers of set $Y^{-4}|k 0|$.

Ir is noted that fusctions and relations as definod within $Z$ provide the formal prounds not colly for mathenatical functions and relations as they are endersood outside the feld. but also for relaxions in relational databases, mechods in object orieniod systems, procedures and routines in conventional progranming languages and links in typentext. They are also esseatial to the developenent of dara modeling languages sach as " $Z$ " $[165]$ and EXPRESS. which is the base langage for the PDES/STEP! project.

Functicens and relasions are used to ouler menbers of sets, and their fomalization is a key pant of the asther's work. This further exiends the iscmoephisen between set theory and desiga information. HM camenaly suppors five ondering nechaniems for devign information baved on functions asd etation. They are discussod in Chapter to.

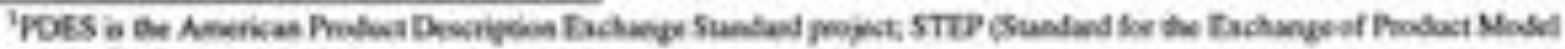

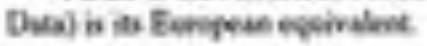




\subsection{Summary}

This Chaprer has inrodeced the fandameneals upon which HM is censtrucled. An examination of the design process (Section 8.1) indicates that exe separale trtament of design informaticn and the processes that act on that insomation is peosible and desirable. Furthemere, an understanding of relevant design information is a nocescary prengaisine befoer an analysis of the design process itself can be attemptod. Conceptual notions of logic. partioularly than of logical rypes from set theory, aft introfuced as relevant beilding blocks foem wèch HM is developed. The fundanental structures and isemorphisms of HM ase introdacod. In particular, the notions of a design ensing and an cbjoct ant introduced as the atomik information units froet which desien models are conotucted. 


\section{Chapter 9}

\section{The Structure of Objects}

\subsection{Introduction}

In this Chupter the nabure of individual objeass and their intemal structure is explomed and defined. The treatment is analogows to the basic definitions of sets in 2I. Only a few new temis and special sets are introduced wo make the resulting thoory specific to engineering design. Tis too is accoptable from a set thoretic point of viex. No new primitives, quantifien of consectives are introduced, thus mairtaining logical validity. The special sets - A. D. O and R - ape neoded cely to distinguish between the various bose entities in IM: they will be sefined as they are introfuced in the text.

\subsection{Definition of Objects}

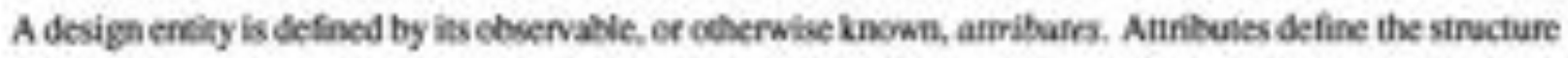
of, and function provided by, the entity. For eumple, a troe is defined by its shape, sine, stengeth of the wood, etc. In fact, the cencepx "uree" is really nothing bet a label attached to a set of observed attribunes that ane shard by all trees [131, 166] Attrhbues ane iapoeant in design because they model identically the properties of entilies in the real world (as epsosed to the percetived, ocnceptual or other worlds).

Let the set of all anributes be denoted by A. and les a, b, edenote memitens of that set. 
Definitien 1 (Definition ef an Object by its Structure) As objecr is a set of unique, identulable, mea. sarable attihuies.

$$
\mathrm{W}(X) \mathrm{K} X \in \mathrm{O}) \Rightarrow(\operatorname{sit}(X)) \cdot(\mathrm{W}(\mathrm{a})(\mathrm{Ka} \in X) \Rightarrow(a \in \mathrm{A})] \mathrm{h} .
$$

Since A is the set of all atribues, we can alpo write this as:

$$
V(X)[(x \in O) \Rightarrow(X \subset A)] .
$$

The set of all attributes $A$ can be regardad as the set of all desiga variahles (like Suh's desiga parameters [31D. Objects may then be seen as a nuard fom of grosping and treating these porameters.

A uelque design entity is one whose anribules difler in some way trom the antribunes of all ceker design entibes. If two antributes (froen two differet design entities) are the sane, then any eperation that can be perfomed on the atributes will yield the same rosults. Since a desigh entity is a set of attribues, an eperabion applied to a decign entity will yield unique results only if there is at leas one attitule with a tnique value in that entify. Therefore, design encibles may be equalod by examining the recults of the spplication of operations bo them, nther than eaminieg their inkemal stracture dinectly. Since objects in IIM model design entities, we have the following asiom:

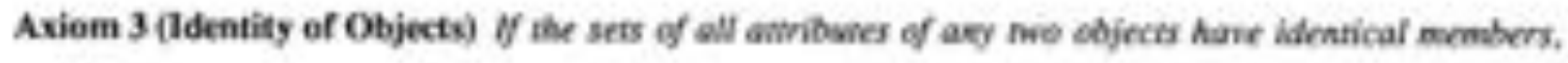
and if corresponding atributes if eack object have cqual nolact, then she fwo objects are identical.

$$
W(X)(Y)[(X=Y)=(\mathrm{V} P)(P(X)=P(Y)))]
$$

nitere $P$ is any unary prodleave.

We ncee that axiom 3 is the same as the Axiom of Estensionality in ZF [s0\%, i.e :

$$
(A=B)=g W(x)(\{\in A)=(x \in B))
$$


but is derived froen design considerations ather than purty mathematical condideratices.

\subsection{Views of Objects}

A number of propenties of otjocts ate very imponant foxm the point of vicw of designe these propenties reinbere the iscmorpeism berween set theory and design information, In this Section and those so follow. these pooperties will be introbachd and esaminod.

The first property is semod relenance by the author, and is is manifested as views of objects.

One of the most useful innace human intelloctual abilitics is to aask out ctrain aypects of an object in favor of other aspects of the otjoct thae are of imponance to ex. For example, a persen could very easily sort a collectione of bocks by their sine, though, if asked shertly theteafter, be completely unable to ecseribe the coblos of the books' covers. Being able bo selectively ignope or roognine infoemation less us isolate and focus our assention cenly on areas of interest. The importance of filtering informarion in desiga eaviroments has been reogrined in the likerature 117.31 .

A vies of an object partitices its attribubes, mabing enly soete visible and matipulable. Vicus donos affect the objoct itself, bet establish a projection of the object whesein only certain aetributes are accessible. A view patitions the attribules of an object according to criteria explicit in the view itself. Alfer pantitioning. the remaining atinltules form a pubst of the atributes of the object being viewhd, that is, a view objoct. An attribue may be active in a namber of views but need not be active in all views.

Epistemolegically, we can abo make the following argument to suppon this aprookh.

An "lidear" object is one than models a design entity in every sctal, property, behavior, etc. Such a detailed model of reality is unlikely to be possible to construct, yer we can imagine it from a theoretical standpoint. In fact, we can likely not even foen such a model mentally, but we can imagine that such models night exist. From a design point of view, not only is i likely impossible to construst such ideal models, but in is also urmarranted. In desigh, we are specifeally coscemod with cnly subses of all the antributes of a dedign enkity. Thus, the logical botion of a view pertmits us to poojod an lifeal model of a design cntity coto a eclevant design model of the entity.

We sec, then, that the isomorphism between set thoory and design foms a cormection that eatends froet 
the very notion of exiutesec fo a specifiable fomal model of existence.

If we consider a particular object so be a "conelete" model of some design entily, then any proper subset of the members of the objoct can be coesiderod a specific view of the objost with respect to the selected members.

Uving the defisition of subeets in $(\mathrm{60}$, we can write is the notabs of HM:

$$
W(X) X Y(Y)[(X \subset Y)=\sigma W(x) \mid(x \in X) \oplus(x \in Y\rangle]) .
$$

If $(X \subset Y)$ but $(X \neq Y)$, the subset is a proper sabse. The namber of possible views of an object is the candinality of the power set $P(X)$ of the object.

Many of these views would be trivially unimponant to a desiguet. Dut there is mo way to define a-priari enly the views that are felevan. Yet, we can nestrict ose delinition of a view in a manncr similar to the way that the definition of a subser is nestricted in ZF. This kind of restriction also happlly prevents certain kinds of logical paradoxes thot wosld nender the theory as a whole imvalid.

We begin with what is generally called the Axioa of Separation.

$$
\exists(S)[W(x)((x \in S)=(\{\in A) \cdot \xi(x)))]
$$

where there awe no free occurnences of $S$ in $\downarrow$. This says that for any set $A$, and any peopositional function (i.e. pedicate) $\phi$, these is a set $S$ that is a subset of $A$ and that contains colly members of $A$ that satisfy $\varphi$. When we say that there can be no fee eccurretces of $S$ in $q$. we mean colly that $\psi$ must not contain accuerences of $Z(S)$ of $W(S)$ since this would imply that $S$ is defined in terms of itsedf and would leat to parofoses. This is not a real problen in IIM itself, becase it would be necaningless to define a vicw with respect io itself, so a decigner would lakely never amempe it. However, it is cafored in HM for compleieness and consictency.

We sefer to the Axion of Separation as an arion-schma because the symbol o mpocsents a growp of

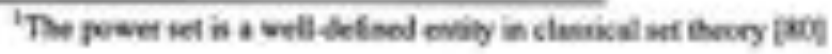




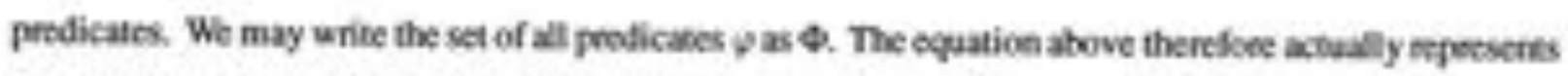
a group of axioms, each having a diffentat prodicate subutinuted for $\varphi \in \Phi$. In Section 8.2.1.2, it was explained that the fesinclod nobure of the universe of discourse of HM lets us investigate the nature of entines within that eniverse much more closely than is poscible in ZF. Here is one example of the depree of detail that is possible: in $Z$. linte can be said about the actual prodicates that can be sutwetituled for $\%$ in the Axiom of Separation but, as we sell see below, in HM we can invectigane a nunber of importast groups of prodicates that apply to design. Views ate the fint such case.

We interpet the Axiom of Separatice for HM views as follows: For an objoct $X$ and any poodicate $\psi$. there is another object $Y$ whose set of alributes is a subet of the antiloules of $X$, all the members of which satisty $\psi$.

The Axiom ef Separation is an axion schema in IDM the axiom of views is in fact a subset of that of the Axiom of Separation, th can be written as follows:

\section{Axiom 4 (Axiom (Schema) of Viems)}

$$
3(Y) \mid \gamma(a) X(a \in Y)=[(a \in X) \cdot \gamma(a) h)
$$

wisere y contsins no foce ocrurrences of $Y$.

Y is a sew symbel, and is usod so represent a mbie of all porsible podicates $\varphi$ that satisfy the Axiom of Separation. In particular, $\gamma$ represenes a prodicate that "defines" a view; diflerent $\gamma$ predicales will pmofuce sfferen views, 7 , then, is the criterion by which a specifie view is defined. These criteria are atritute-specific. Fee exanple, if $\gamma$ were such that only annibutes that modeled ipocial dimensions satisfied it, the sesulting view of an object would be ins 3D geonecric fepesentation.

Let the set of all views be denoted by $\mathrm{r}$, and let 7 be a member of that set.

The notion of a view being a sabest of an objoct is captured by the following defaition.

Definition 2 (Views) VIEWY) is a binary funcrios whose paramesers ane an object asd a wirw criacrian specification, and whase nesult is anocher object calind a view object whase athibuses are a rabset of the atributes of the input ebject selected accending no the gives criterion. 


$$
\eta(X)[\mathrm{W}(\tau) X(Y)\{(Y=\operatorname{VIEW}(X, \gamma)) \cdot(Y \subset X)])]
$$

We can write this ì a functional noexion as

$$
\text { VIEW : } 0-\text { DNOK- }
$$

Objects that are the same in every regard afe identical. This applies to view objects as well. However, this notion also sagests a felaticnship betwoen the objocts from which the views were generaed. If there exists a view objoct that can be derived from two noo-identical ebjects throwgh the use of a single view criterikn $\%$, then we define the two non-identical objects as being sindilar objects.

The inclesion of simalar ebjocts in HM is mosivated by the obecrvation that for many design tasks, only a certais view of as object is sufficien bs permit completion of the task. Since views are projections of objects, in becomes iaperate to be able to make statcmonts about the objocts that give rise to such view objocts.

Theorem 1 (Similarity of Objects) Tho objects ane similar vf the applicanian of a given view crikerion 7 to the objects produces identical vien objecrs.

$$
v(X)[V(\gamma)(W Y)(X \sim Y)=(\operatorname{VIEW}(X, \gamma)=\mathrm{VIEW}(Y, \gamma)))]
$$

The symbol $\sim$ is used to dencee similarity of cbjocts.

The author'smotivabion to have viems of desige infonarion is five-fold. First, we have the epiotenological

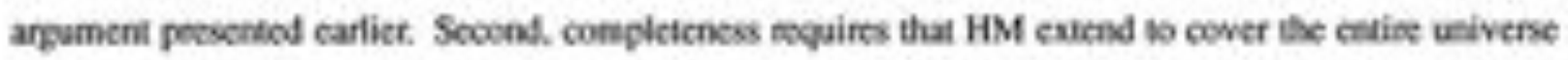

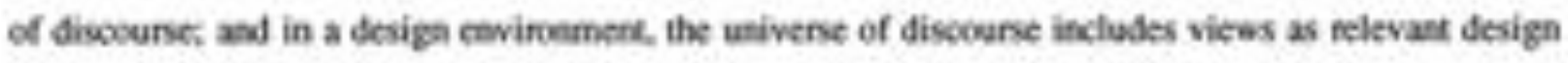
entides. Thind, from the standpoint of conclacness, vicas permit a siructure 69 exist in the simplest foem the waintains its scmantiks. Fourth, from as organizationd standpoine, view permil infoemalion vo be 
ordered by its relevance to a task. Fath, and lastly, views implenent infommicen hiding, which is desinhle proctically for a number of masoss. The designer will buve a simpler task if onlly nelevane infomasion is visible. lnformation selocted by view can be preseniod to the user in a mofe andensandakle form. Superhuovs informatice can be excludod to increase efficiency asd fobusthess. Mone practically, views can peovide uniform ineerfaces bo pans of a darahase eveat though the intemol stoucture of the objects in the database ayy charge.

Vews are an especially powerful woll whon detinod as componenes of atnilutes. For example, an atinibute occuming in two diferent views may indicate coupling berween the views. Aliematively, the sets of views of two objocts can be imersected, whertupon the cantinality of the intersection set can be used to measut functional or ether coupling. Sizilialy, small sets of views can be used in order to stufy how different types of aniloules affect the coupling of two objecte.

\subsection{Domains and Ranges of Attributes}

\subsubsection{Set Theoretic Foendations}

The secied impertant peoperty of objects has 15 bo with the structure of the atributes that compose them. Here, we introduct the necessary set theoretic bockgroend 10 formalize ceject attilbules in HM. We begin by exnsidering the formal definicion of a malarios en sets.

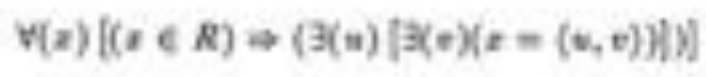

where $x$ is an osdered poir, a $\in V$ and $e \in V(U$ and $V$ art sets) and $R$ is a relation.

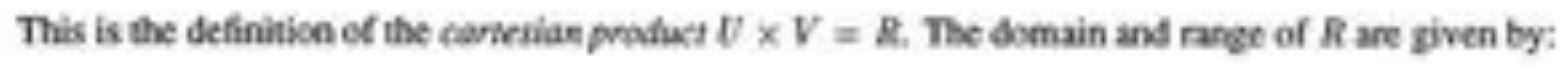

$$
\begin{aligned}
& \operatorname{doe}(\boldsymbol{R})=\boldsymbol{\psi} \quad\{x: \exists(v)(x, y) \in \boldsymbol{R})\}
\end{aligned}
$$

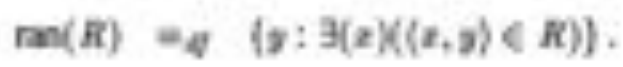


Let $D$ be the set of all possible amnbule domains and $R$ be the set of all possible attribuse fanges. We may now write:

$$
\mathbf{A}=\mathbf{D} \times \mathbf{R}
$$

and $\operatorname{dom}(A)=D$ and $\operatorname{man}(A)=R$. Alvo, bocause of definition 1, we can write foe an objoct $X$ :

$$
\begin{aligned}
& \operatorname{dan}(X) \subset \mathrm{D} \\
& \operatorname{ran}(X) \subset \mathrm{R} .
\end{aligned}
$$

\section{4 .2 Domains and Ranges in HM}

An antribute representing a poperty of behwior of a designentity is specifiod by two pleces of intomation.

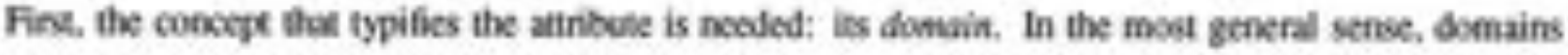
of attributes can include insegen, feal numben, leas, arrags, etc. The domains of attributes nelevant bo engineering design afe discusad below, Sected. a specification of how the property is exhibited by a particular entify is roquired. The sct of possible values that an amitute can have is called the nager of the atribute.

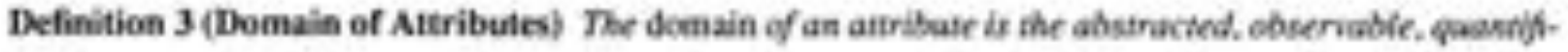

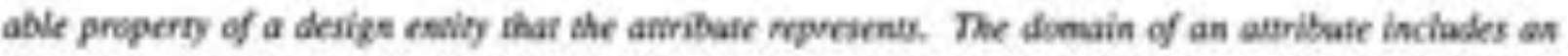
assochated dimensional ank.

Definition 4 (Range of Attributes) The range of as amribate is ihe set of all values ahar are mrasinglal

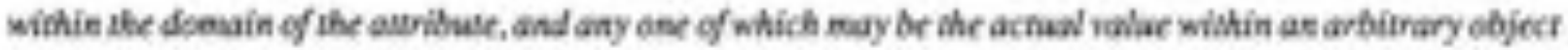

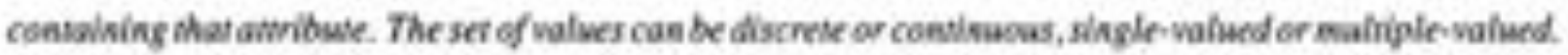

The dimacreional units mentionod in these definitions are discussed below.

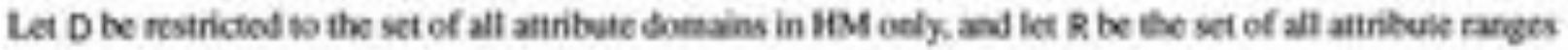
in $1 \mathrm{MM}$ only. 
Definition 5 (Attributes) Amributes ane ondered polrs $\langle d, r\rangle$ where $d \in D$ and $r \in R$, and the ser of all amribues is the curstrian product D $\times \mathrm{R}$.

The definition of the cartesian product and its nelationstip ts ondered pairs is defined within ZF. We use ZF here so perside a formal definition of attributes.

Theorem 2 (Identily ef Attributes) Two amribuses are identical if their dowalss ane idenical and meir ravges are equal.

\subsection{Dimensions of Measurement}

There is an importane chervation that must be made at this point neganding awributes for engineering design. To be meaningful. attribules must nos only be obervakle; they mud atwo be measuble. If an attribute is not meacurable, its valee canne be ecmpard to other values er used incemputation, and would

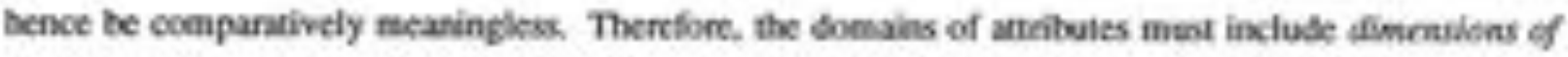
meanarewent against which the amribute can be coenpard. Tas is asother important property of objects in $\mathrm{HM}$.

In onder 60 satisfy the condition of newornbility of antibunes given above, the author has delined the members of the set of altribute dsmains D to contain dimensional propenies. The menbers of $D$ in HM are: Ienght mass, time, cost, quanity (oe ensmeration), NDU (nce-dimetrional usitx. foe ratios. enc.) of ary combination of these (tes velocity, energy, and so on). Although only length, nass and time ane commonly coesidered, the whor has elected to add ether dimensions because of their selative impertance in enginecting cavifoements. This aptooch is far mont powerful than schernes that only represent numeric quancities because it is a satural form of expression that is pergsically meaninglal. and becase it captures alt the nocessary semantics of dimensbonal standards at the asiomatic level. Foe example. correct direonional analysis becoetes an inherent property of HM. Dimensional information has alwo been found to be of great assivence in deating with spatial constraints [167].

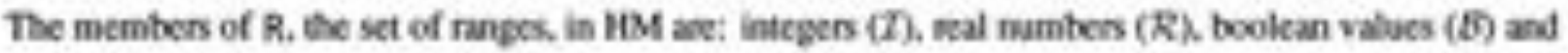
text $(T)$. The author is undecided as to whether complex nambers shocld also be included as possible 
range values: though they are of we in many design methodologies (particularly in the area of atulysis. they can also be considered as composibes made up of two real numbers.

The auther believes this approach to be superiof because it is a very macural bea of expression that is ptyokally meaningful, and it captures all the mecessary semintics of dimenional standands at the axiothutic level.

\subsection{Constraints and Attributes}

Condraints are the principal driving force of the engineering design process. They are manifested as relationdaps betwetn infomation segating design entities. Insofar as coestraiets afe vital op design infomatice specificalion, they mas be represened by HM.

As with views (Section 9.3). constrainss operase an the attribute level within HM. Both artribute domains and ranges magy be consainod. Anritute domains may be condrained wo be of specific types (e.e. modular assembly couponents might have a coestrined kind of shepe or material), and attribuee values may be comtrainat vo be coestam-valued, single-valued of mahtiple-valued, continucus ee discontinucus, and so on

The isouc of cotstrainss in desige is far moec coenples than may be implised here. In general, the constain satisfactice probleme is characterieed as NP-complete [55-57], which means the time royeisod to solve the problem varies exponentially with the size of the problem. For evea snall desipa pooblems, the requind computation can be intractable. Howevet, the procers of coestraiet salisfaction is a component of the desiga process irself, and thenefore falls oesside the bounds of the imsactiane concen of the anthor in this woek. While this simplifics cur tak, we recogniec that move work is neoled befort HM can suppon

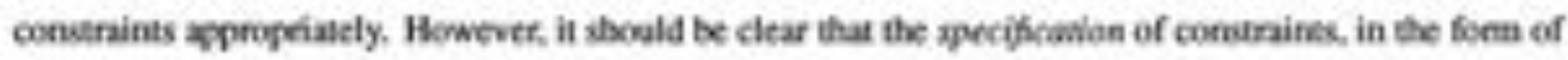
fenctions and nelatices that define subsets of attribstes and ebjocts, is inhenent io HM.

It is noted that the set D X R (fiscussod atove) contains artributes that ace mearingless in a design environacnt. For exasple, an atribute with the domain of quantify cannot have a range within the set of real numbers. Clearly, some constrains will be necessary jest to kecp a model corsistent with nespoct bo attribuse definition. 


\subsection{Summary}

In this Chapter, the basic strustere of individual objects and theit irmemal structure has been presented Scenally. An cbject models a design entity, and is defined as a set the members of uhich afe antribetes. Each attribuse has a domain, a range, and an associated dimendion of measuncacnt. A view of an object is a sulvet coaporied of antributes of the object that satisfy some predicate. Views permit the ivolation of selevane antiloues based on enemally sapglied criteria. Variows primithe relationships betwoen objects (e.e identity, similariny) are also formailined. Three which issoes remain for which further research is indicated. First, the role of vieus has been idenaifod as key to a namber of acplication domains.

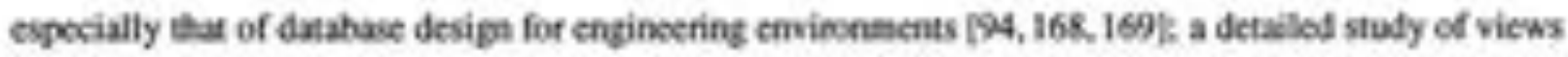
cosld be highly beneficial wo sech efforts. Sccond, the unique aproach uken with segatds bo dimenisons of measuremert showld be imcstigatod more fally. Thind, the pivoeal role played by constraints in the design endeaver mabes their further stody welevant and importane. 


\section{Chapter 10}

\section{Ordering Mechanisms for Design Information}

\subsection{Introduction}

In this Chapter, Ee author identifes valious ondering schemes (abjtraction mechanisms) that cas be imposed on enpinecring informakion to make scmarkic oonicri eaplicit. These mochanisms are derived from considerations of the types ef information available to a designer and are defined wilhin a sen thooretic framework (i.e. HM0. They represent primiltive onbological actices based on how devigners negard the univeche. These notions cover the classification of design entifies accoeling 10 various criterix, though extralcgical in and of thetsolves, these notions are well foended is empirical seseanch in ptiloseptry. poychology, and artifeial intelligence $[28,131,166]$.

The matter dealt with is this and the followiag Soctions cocupies a higher level of ahstaction than the manter of Copter 9: we discuss staeements about collections of objocts, nther thas jest individual objocts. These collections are (classical) sets of objocts, and bey obey all the notiens and axicens of ZF set theory. Objects are organized by enablistieg selationstips berween them. The kinds of relationships are independen of the objects that rake pan. Consder, for erample, $X=f(Y)$, whene $X$ and $Y$ are objects. The function $f$ may be appliod to many objects, and yicld many objocts. It tous defines sets of objects $C$, and 
$C_{j}$ such than $X \in C_{i}$ and $Y \in C_{j}$. The orgatiration of object, then, procecds by defining the relatioes that in tam define sets of objocts.

We recogeine now that the set 0 the set of all objocts, is one of these collections. The oclatioechip betwoen the members of this set is that every member is an object. Similar arguments may be made for each of the sets introdaced in Capter 9.

\subsection{Types of Objects}

One of the most natural and useful abstraction mechaniens for costering (or classifying) entities is by structural (as epposed to behaviond) similarities of the eritics. Sometimes called "classification" or "typing", this mocharism is also a basis of humas cognirive fanction in general. Ondering schemes of this type are only partial because asay sach shemes may be imposed ca the same collection of entities, each yielding a differently ondered collection. The human mind thinks about entities so grouped by thinking

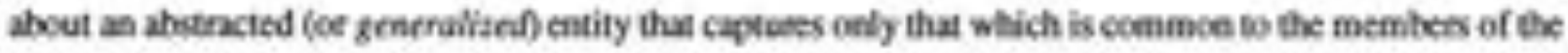
collection and leaving indetermitate (or at least variable) other aspocts of the members of the collection. In HM, the generalized, conceptual entity meant to represent a partially ondered collaction of design entities is called a bpe. The partid onders that types impose on collections of entities define relationbips thared by the members of the collections, thus making information regarding the members explicil. Sece

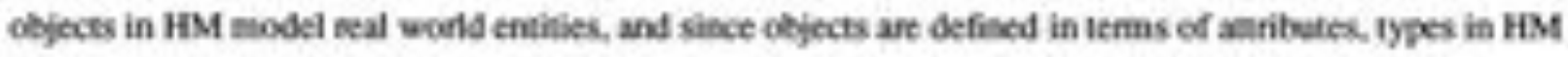

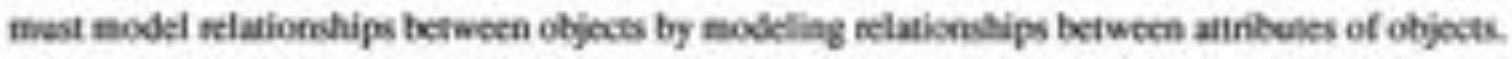

The distinction between a type and the collection of objects that the type models must be bepe clear. A collection of partially ondered objocts is. exuentially, a set of sets, and henoe exiats at a diflereat degne of abstraction (or logical level) than do objocts. A type, on the other hand. models a oolloction of ebjocts, and therefore exids at the same kegical level as do objects. This distinction becomes crucial if we are to insure that HM is coesistent. The netion of logical levels descends from Russell's Theory of Legical Types [153] and is a generalized mechanien to distinguish between sets, based on the degree of abstraction fequired to crease the sets. The Axiom-Schema of Separatices, as it is used in [1. 20.153$]$ and by the auther, implies. this same distinction between logical levels. Thes, $\mathrm{ZF}$ supports the distinction of logical levels acconding 60 Russell's theory. The distinction is also imponare to HM. 
The key bo providing a consistev thoory of design informatioe lies wib the Asiom of Separabien, wilch we have already seen in Sectioes 9.3. Agaln, our approach is to interpret the Axion of Separation in terms of design considerations and eventuvily draw forth a goup of predicates that can be substituted for $\varphi$ in the Axicen which has meaning from a dedign standpoint.

For a given object, we mipht expect prodicates sach a "This exily has a threaded shoff" or " Dhis entity is made $e f$ cold molled steer". For a type collection, we might expect predicates sach as "This earity is a boir" ee "This ennity occuples spoce and is made of mrar". In considering type collections, we disregand any prodicales that depead en the values of ansitules of ebjects; ice, we krow at once thas a predicaze such as "This entify is 3.5 centiverters lang plus or minus I milfiweter" applies to an object, while a preflicane such

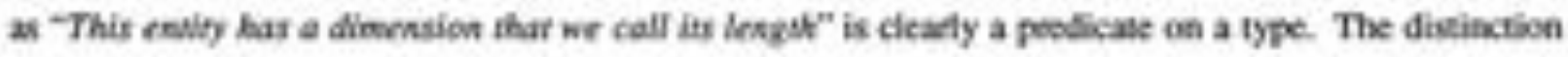
is thet the former is a prodicate on a design entity and the batter is a podicate on an abotract entity that gencealizes some aspect of the former. Also, the former aentices an annibute dotain (lengh) and a range

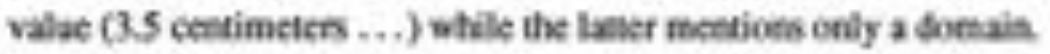

In ether wonds, the process of generalizatice of antibetes imolves neglecting the values of the attriluus and dealing oely wide their domaiss. That is, attributes that ane prodicable on type collectioes are nos peticable en design enkities or the objocts that model them, bet on generallnations of the design entities. In a more proctical sensc, we nay stabe this as follows:

In HM, objects ase fophd (of clasified) by their saructure; sinilasities in seructere afe expresed by similarities is the domains of the attributes of objoctk. Altributes of objocts are quartitutive measabs and nepecsent in HM only those quantitative aspects of design entitics.

The criterion usod to Aefine a collection of objocts is basod on artribute domains. An object is incloded in the oollection if the domains of all its attributes map idencically to all the domains in the criterion. Intsmasien defining the crituerion is supplied by the type.

Axiom 5 (Abatraction of Structure) Abseracrios of ebject structare is based en generwilatios of object

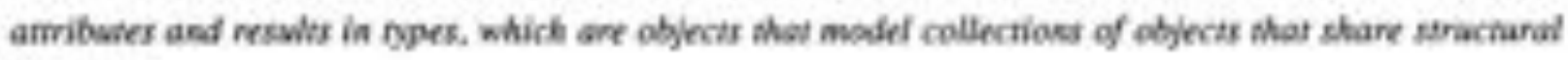
Nemares.

Let a type collection be denceod by $C_{T}$. 
Definition 6 (Type Collections) A rppe cellection is a ser of objects, the dsmains of the amributes of all the meabers of wible are the same.

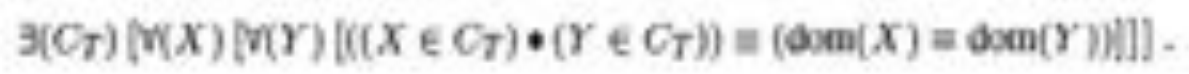

We nete that the phraves $\left(X \in C_{\gamma}\right)$ and $\left(Y \in C_{r}\right)$ obey the nules of kgical types (see Section 8.2.2)

We can represent all the infomation necessary so defne a colloction $C_{T}$ for types by meass of a objoct. Specifically, for a type collection $C_{7}$, a type $T$ is defined as an object whose doeazin is the same as the demain of every member of $C_{T}$. This defines the minimum necessary infomasion wo capture the notion of type collections.

Because types and type collections are based on objoct domains only 0.c. range information is ignocod.). then any member of a type colloction $C_{T}$ can fill the odle ef type $T$. That is, for a type collection $C_{T}$. we may take any member object form $C_{r}$ and successfully use it as a type for that type colloction. Thas type ebjects $T$ ase not actual objects distinct from ether objects, but are rather erdinary objects that we concider in the mole of mposentatives of their type.

We may denote the set of ail bypes by $T$. therefore $T \in T$ and $T \subset O$.

We detine the binary prodicate is. $A$ to capture the typo relationship between two objocts.

\section{Definition 7 (The Typing Predicate)}

$$
\mathrm{V}(X)[\mathrm{V} Y)[\mathrm{S} \cdot \mathrm{A}(X, Y)=(\operatorname{doan}(X)=\operatorname{doa}(Y))]] \text {. }
$$

The author notes that if $Y$ were definod to be the type for its type colloction, then is.A could be wed to detemine if artienary ofjects were "of a given ope".

Futhermon, it is roduxdast os have moe thah ene bfe object foe a given type collection. However, nothing has been said yet that would prevent two objocts of a given 5ype collection freen being censidesed types. We can expeure the eniqueness of type objects using a notation suggested in [1] wo indicate the exisence of unique individualk. 
Theorem 3 (Theorem of Type Deiqueness)

$$
\mathrm{W}\left(C_{T}\right) \| \mathrm{Y}(T)\left(T \in C_{T}\right) .
$$

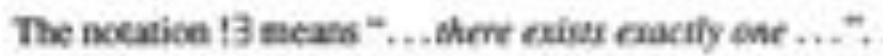

Now let us ectum to the Axicen ef Scparation. If is writen

$$
\exists(S) \mid V(x) X(x \in S)=((x \in A) \cdot v(x))\} \mid
$$

and stakes ther thete exists a stber $S$ of a set $A$ all the menbers of which satisfy $\psi$ (with no free occurrences of $\$$ in $\emptyset$.

With regand to types, the auther interprets the axion as follows: there exists a subet $X$ of the set of alt objects $O$ all the members of which satinfy a prodicate $\theta$. In this case, $\theta$ is the predicate that differentiates objects by type - in other words. IS.A. Wo can then write the Asbom of Scpartion for types in HM as the following axion schena:

\section{Axiom 6 (Axiem of Typex)}

$$
\left.\forall(Y) \quad \exists\left(C_{\tau}\right)\left[\eta(X)\left(\left(X \in C_{\tau}\right)=(X X \in 0) \cdot \operatorname{tS} \wedge(X, Y)\right]\right)\right]=
$$

Tho spoce separating " $7(Y)^{\prime \prime}$ from the rest of Equation 10.4 is a comentice used in symbelic begic to indicate the extent of an axion with nespect 00 a set of ensibies. In this case, it binds the use of $Y$ in the axions so as to explicitly define the range of values that $Y$ can atrain within the axion.

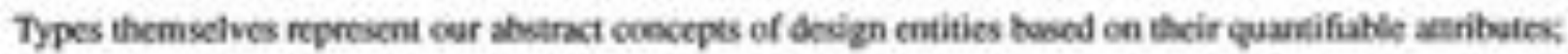
they define the pooperties of a set of design entities without defining the degree to which each rali world eaty erhibins those properties.

In aserapting to pelate objects and types, the fistincticn between types and the eellectices of objects that types model is essential. Collections of objects ane not dimoctly comporable to objocts because they are of different degroes of abstraction (see Section 8.22 ) that is, apsoneralfy intuitive statements wach as $X \cap C_{T}$ 
and $X \in T$ are invalis, the system resulbing from their inclusion would becoese inconsiswerk, and these weuld be no way of assering that all statements that can be formulated in KM can be proved. On the other hand, stasements of the form $0 \cap \mathrm{T}=\mathrm{T}$, of $X \in C_{\mathrm{T}}$, are accepuble becase 0 and $\mathrm{T}$. and $X$ and $C_{\mathrm{T}}$. ase of the same degne of abstraction.

This is a good exarnple of the power of set thoon: is forces ws bo think mone clearly by giving us a systom

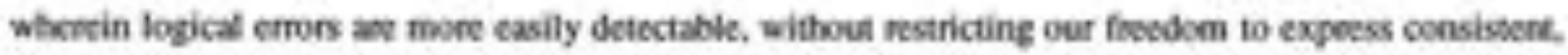
relevare indonmation. The majoelty of logical emors are detectable because "statemenes" in HM ate theofens; if they can be proved withis the sysers, they are valis (comod). Not all crrors can be caupht Eis way because of the inherent incompleteness ef fombal systems (see \$ection 5,1).

The relaticestip betecen a type and ebjocts of that type (the rope-object relationship) is a ene-to-many relationship. But the relationship betwoen as objoct and its type (the object-ope nelationship) is one-tocne. We would have to be outude the system so "see" that the curnent object's type has mone than one

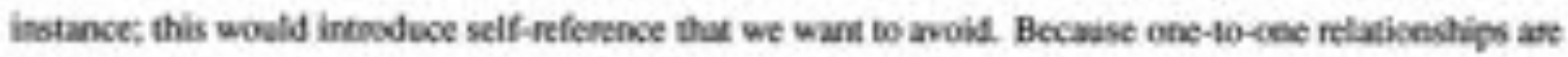
dealt with in a straight-forwand fachion with functions, and becase of the addod exmplexity of dealing with boeh objects and type cellections of objects, HM models ebjocts as hrving types, rather than types as having ecllocticess of objocts.

Furtheramore, types collectices $\left(C_{Y}\right)$ are net considerod to be primary entities in MM. Design entides afe the only entities of primary istpcetance, since they ane iscntificd with real-world crtities melevant to designers. Types collections, thowgh essential on the theoretical gounds discussed above, ane derivind

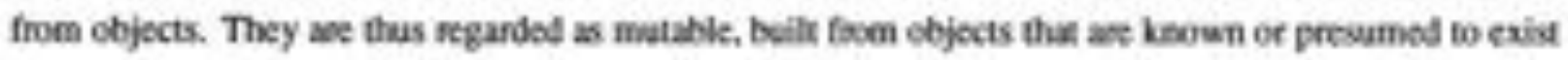
in some way. This mus be the case because the underlying foquiremens of the crineria for the formation of types ca change during the coure of a design process, ee as our cellective undenatanting of design evolves. If we were to define fypes as immatable structures, we would be locking cunclves in to a particular viewpoint of the nature of sesign which might bum out to be insufficlent.

\subsection{Aggregations of Objects}

We have seen that types permit the ondering of objocts, wing aburaction of the ateributes of cejoctx. 


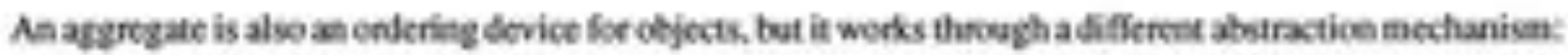
rocursive containmen. Put simply, an angregate is just a collection of ebjects. Membership in ageregate collecticns is based en entirfly artitrary critera the depend on the exigencies of the pooblem at hand. This distinguidhes aggregates from types, for which the defining criberion is procise and knosn a-prisri. Afzreganes permit the hierarchical ondering of objects of the same degree of abotraction (ie. asgregates cannot mix objects and types). Design is stongly hienarchical. Parts may be assembeles of other parts. Even processes (for example, a firite element analysis, ef a machining process) ase composed of sabyocesses. The larger the design problen, the more important hierarchical ondering becoetec.

Once again, we rely en the Axiom of Separation to guble us in formalizing osr notice of agesezaes. In thlis case, we wrine the Axion as follows:

Axiom 7 (Trial Asiom-Schema of Aggregates) There exists a collection of objects $C_{A}$, aff the mocobers of which satisfy a particular predicate 8 .

$$
\left.\exists\left(C_{A}\right) \mid \forall(X)\left(\left(X \in C_{A}\right)=[(X \in O) \cdot \delta(X)]\right)\right]
$$

$C_{A}$ is an agentale colloction, and $\delta$ is oec of a set of prodicales $A$ used to define memlership in the ageregate object that model these collections.

However, we ebserve thes (1) $C_{A}$ and $O$ are colloctions of objects, and (2) $\delta$ applies oely bo single objects in $C_{A}$. Defining $\delta$ in terns of $C_{A}$ beraks the restriction of free variales on the asiom of sepacation. Therefore. axion 7 itself is not enough to define the relasionship between membens ia an aegregate-

The generally accepted theory of clases of sets [170], which accounts not enly for sets but also for collections of sets, actileves nothitg for us except the replacement of poofleates like $b$ by classes of objocts that ase \&efined in ierms of $\delta$.

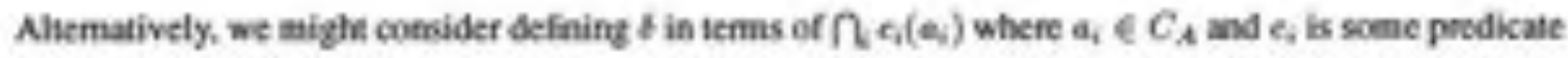
constraining $\omega_{4}$. Dut in this case cach oxnstraint depends on only ene member of $C_{A}$ - whereas we need a shingle retacionsip over all the mentoen of $C_{A}$.

To solve this problem, let us begin by saying that a relabiondip is neoded to define the nurafe of the

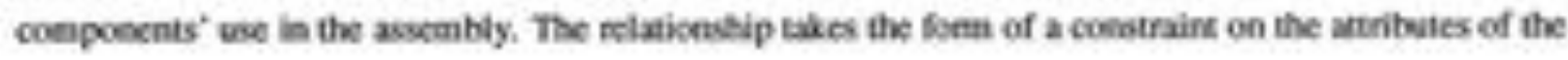


ascembly (an afzregate object). Thus, the constrain is at the same logical level as the aggoegue, esf at

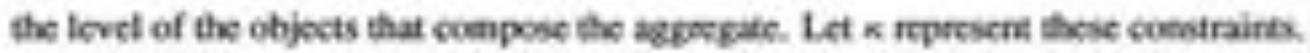

In general, a condraint of this kind on an afgregate will not act on all the attribetes in the aggegate. For example, a converain defiring the melaticnakip betwoen two lisks in a four-bar linkage nect net act en the cther links. Sa, in general, a constrinit will act on a subset of the atinibules of an agerepace.

Now, a view (ese Soction 9.3) is a subset of an object. If we sefine a centain vice of the asgregate to concain enly the anributes actod upen by some ageregison cotstraint $\kappa$, we may then say that the cocetraint acts on aff the attributes of the view, Now, we can begin writing another axiom, based ce views of an aggregate. Each coestraint $\mathrm{k} \mathrm{cas}$ be usod to define a view criberion 7 , which in tora defines a view. Thus a collection of constraints $\kappa_{q}$ for an aggregze leads bo a colloction of view criteria $\gamma$, and a collection of view objects $V_{k}$. We nor define $C_{A}$ more procisely: $C_{A}=4 V_{2}$

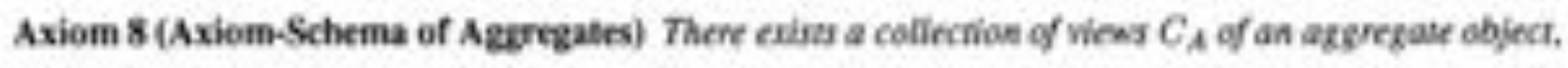
aif the nembers of whick sadiffy a parricular pondicate $\delta$.

$$
\exists\left(C_{A}\right)\left[V(V)\left(\left(V \in C_{A}\right)=\{(V \in O) \cdot i(V)]\right\}\right.
$$

whene $t(V)$ mut be true foe all views in $C_{A}$ : the is,

$$
\theta(V)=\psi\left(\kappa_{i}\right.
$$

This equation will be true if al leat one $\kappa_{i}$ is true, It is noted that this is counterintuitive: we might have ascumod that all constrints must be simaftancously true $\left(i \varepsilon . \eta_{i} \kappa_{1}\right)$, but this is fot the cave.

Sisce atinloutes appearing in moee than cee view object of an aegregate afe identical (est cely equal or equivalent - see Section 9.3), we can crease the ageregate objoct itself by simple union: $Y=U C_{A}=$ $U_{i} V_{i}$

A graphical depiction of the aggegation of four links bo compose a fowe-bar linkape is given in Figure

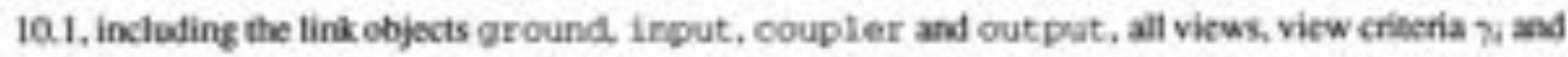
cotstrainss $\kappa_{i}$ - 


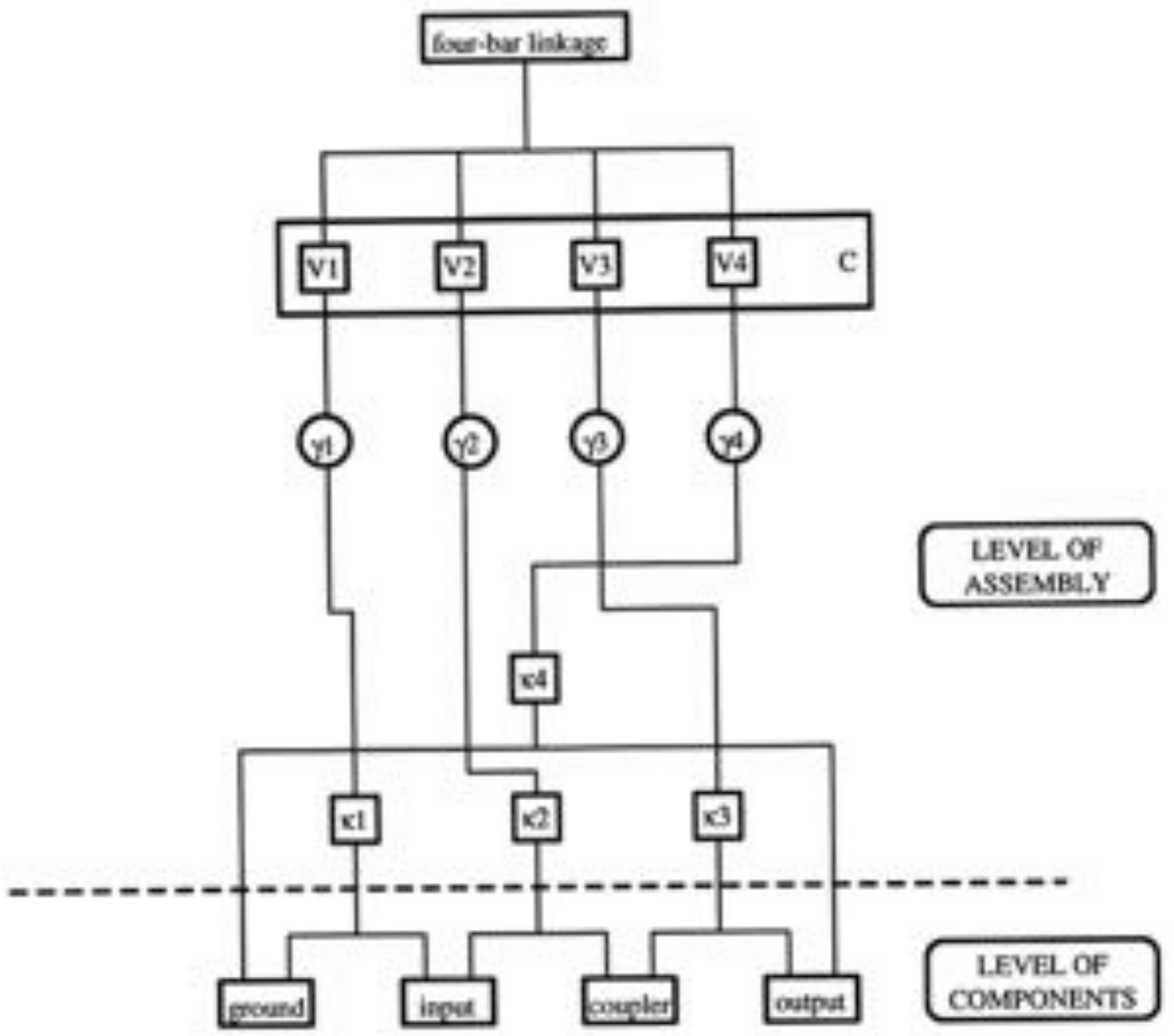

Figure to.t: Agprezation of a Four-Bar Linkage in HM. 
The proflicase set $\Delta$ is an important oot: its elements peovide the means of defining all the necessary relintionships in an apgregate object. The censeguenoes of this stacment are made quite clear by condid. critg a simple physical asernbly of components. Cejects would model each componern. An aegregate objoct would model the assembly. It would be the pole of the $\delta$ poodicale for that asceably not ocly io partitien objects acconfing to which are necded in the assembly and which are not, bet also to provide the enat relationhip that evists betwen the coeponerss in the ascmbly. In other words, it is the aggnepabe peodicanes $\Delta$ than permit the defirition of how components in a physical asiembly mase, the bierances of the fr, the manner in which the mating oocus (the assenbly process itself and so fonth.

An aggregate objoct nood noe coetain anly other objocts, but ean itself have unntutes. One obvious cxample of the kind of amributes that an aggrtgate ifself aight buve are size and shape. These cleally canos be derived from the components of the aggregate alone fe.e. infomation about a bolt wells us nothing abeut the assembly in which the boll is to be wed). This too is pemienod by HM. Agegegane objocts, then, are net just sets of objects, but an object with anrilouses whose valoes ase celer objects.

At this juncture, we couly begin a detalled study of ese properties of the predicates in A, but shall noe. This document is mean wo be both an overvicw of HM and a stabenent of the fundamersal axioms that compose in. In this spirit, then, we defer such discussions to fubure wek.

\subsection{Classes of Objects}

In addition to classificatice by ancocture using types, objects can be also classifiod by the functice they are meant to porvide. The impertance of capturine semantic coment of function is best excmplified by conceptual design.

Conceptad design is oese of the first steps in a design process, and has the greatest impact on downstream docisicns $[17,42,171]$. In general, coscepted desiga is consdered to be the mapping between the function provided by some entify and the physical specification of the entity. Very liole is known about concepeal design and we do noe presume a simple solution to the protlem here. However, the autwor has devised a mechanism to ease the development of a spatem of classificasion by function.

The mapping between structure and functios is not nocessarily ene-t0-one: a particular structural com. 
ponent may provide moee than one functioe, of vice versa. The mechafism of types discessied ia Section

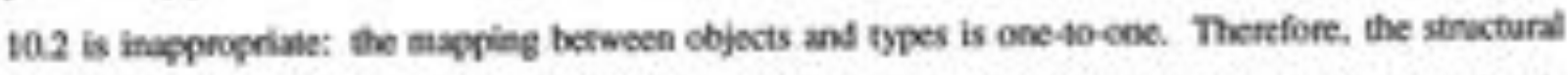
propertics of the entity do not capture semastics of function. A mechanisn diffenen froen typing is requised.

The auther defines a ciass of ebjocts as an ageregate objoct whose memhers all repeesen design entities that eshibil a given function. MM concider inclusion of an objoct in a class sufficien to establish that the object exhibits a given function.

It is unclear to the author at this time whether a class should include informaticen foe modeling of the function itself, of whether this informatice saould be containos by the member otyocts, of by the $t$ function of the aggregate that relates them. The selationship modeled by the function would permil access bo the members of the clask, much as IS A provides, bet without the constrints that IS_A inposes oe the attribues of menber objocts.

\subsection{Specialization and Generalization of Objects}

\subsubsection{Specialization of Types}

The abetractice mocharism of speciolitation is implementod in HM by isheriasice of type. Inheritance is a mochatikm similar to ageregaticn. bot is centrollod by the operation of ser anien.

The difference between inheritance and augregation is very important froen a semaetic point of view, For example, to say that an assencbile inherits the atriliases of its engine (e.e. power) is meaningless; the reason why humans can mabe sense of sech statements is because we cas intepper it comectly and extract the necescary invillo infoenasion from the statement. Bowever, this highly informal ind subjoctive approach is very undesinble. The corrod satement the can be supported by a formal theory would be that the aulomobile is an agzregate, one componene of which is an engine that has a certain power rating. Bocause HM is meant to fomalione desigs informasion, the distinction between aberegation and inheritance becomes essential.

A type, then, is the unios of alt the atritules of the types that are inherited by it. Unien of sets is very 
well understood in set thoury and provides a simple and rigonos way to foenaline specialization throwgh interritance.

Using the Axiom-Schema of Separatice again, we can write the following.

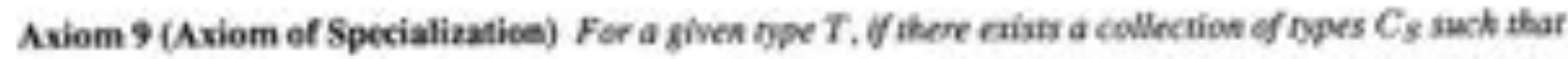
$T$ conraier all we attributes of all ihe minhers of $C_{S}$, shen $T$ is said to inherit from the menbers of $C_{5}$. and $T$ í a ope specialized from the toper in $C_{5}$.

$$
\text { WT } \quad \exists\left(C_{s}\right)\left[V(U)\left(\left(U \in C_{s}\right)=[(U \in \mathrm{T}) \cdot(U \subset T)]\right)\right]-
$$

We can define the predicate EVHERrTs as:

\section{Definitien 8 (The Inheritance Predicate)}

$$
W(T)[H(U) \text { INHERTS }(T, U)=(U \subset T)]]=
$$

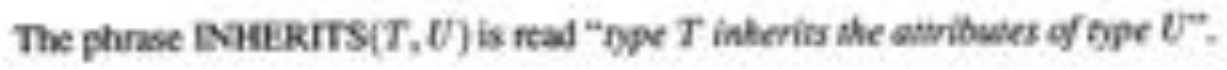

As is the sandand definition of the anion eperation, duplicase elemones are excladod from the union set. The idestity axiom (aviom 3) defines the criterice by which duplicases ane ifentified in HM.

In design, specialization is an inportan mechatism because it permits the creation of specialined types from a colloction of more genenal, absiract types. It is, therefort. a top-down procedure.

Design also icnds to be a top-dusen process $143,49,69,106,126,167,172 \mid$, moving frum the gencral (cesceptual design) to the specife (Sctailod design). This impacts on how we treat design information. Becaste design begirs from the general and moves to the specific, we can expect that at an artitrary point along the developenent of a devign anifact, information nepanting the artifact will be incemplese in detail. Specialization, thes being a top-down process, is esed in HM to permit incomplde infonation atoot design entities wo be captured in a consistert maner, and so peratr the generation of (application) specife types troen gencral types. 


\subsubsection{Generalization of Types}

Generalisalon is the inverse of specialization. and from the purely thecectic point of view of MM. the selationship betwen the two is bidifectional (i.e. spocialization and genenlizxtion are coposites but equivalents). Thus:

Axiom 10 (Axiom ef Generallation) Voll ahe asmbers of a collections offops Co have sowe attributes

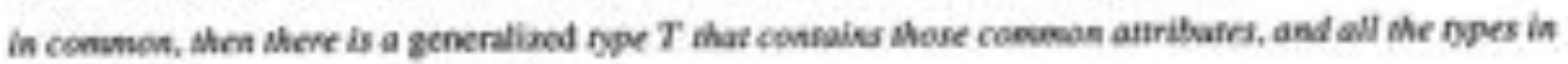
Co interif the coenon amributes fhom $T$.

$$
\left.\exists(T) \quad \exists\left(C_{a}\right)\left[W(U)\left(U \in C_{\theta}\right)=[(U \in T) \cdot(T \subset U)]\right)\right] .
$$

Gencralization is imponan to design too, for two reanos. The fint is quite practical: in an emvironment where a number of types of design objeces hwe been generabd independent ef each other, generalixaicen provides a fsemal mechariam by which we can anify cur models of the objects. This kind of unification minimises the anount of information scoded to completely specify a design artifact model, making the model simpler and cleacert.

The second reason that geteralization is important has to so with thecetic, tawonomic conoems. One obviousty desinble goal is decizn theng is the generatios of usable. globally applicable taxonomies of design entibes. The isoue of tawoomy in devign thoory was discussed in Section 4.2. Taxencenies themselves can help standardine our modets of desiga entities and control the information required for the models. Ceneralization in HM gives ws a very specific formal methobology for generating design eritity tawnomies. Taxoenenles resulting fron the applicatioe of scneraliratice so types in HM would recult in inheritance networks ef types that wodid pennit the classification (at leact in theory) ef artitrary kinds of dedgn entitics. The iswes involved in generaing soch tawonomies are inseresting and many, and are nos dealt with specificaly in this documeat.

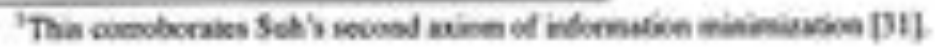




\subsubsection{Relationship Between Specialization and Views}

Assume two types, $T$ and $U$, and a vicw crikerice $q$ that coly examines object doensies. If the types are similar under the view crinerioe, thos the vicw objecs bsmed by applicasion of the criterion to the type objocts an idantical. Therefoer, the view object itself is seen as a bpe frue which types $T$ and $U$ inbert atributes. This may be written in the notation of $\mathrm{HM}$ as

\section{Theorem 4 (Similarity of Types)}

$$
\begin{aligned}
& \mathrm{Y}(T)(\mathrm{V}(U)(V(\gamma d) \quad(\text { VIEW }(T, \gamma d)=\mathrm{VIRW}(U, \gamma)=V)= \\
& \text { [INHERTS }(T, V) \cdot \text { [NISERTS }(U, V))]] \text {. }
\end{aligned}
$$

This further reinfores the importance of vieas as an orgarisational mechaniea: we see that vicus can be used to define the conditions whenty inheritance between otject typos oscurs.

\subsection{Summary}

The author has presented in this Chaper five ordering mecharlisms for objects: tying foy structurti, agergatios dasificasion (by function), specialization, and generalizason. These five mechanisans provide the means of oefanizing collections of objects in meaningfal ways (in a desiga contextk sach organiration of information is essential to maximiring the anouet of explicit information a desipner has arabable to him/her, which in tum can decnease the chances of misinberpreting design informatice. The endering mochanisms are based on onbolopical cuesiderations of mal-world entities, nee on the empinical evidence as provided by the conventional undenending of design. In this way. indopendence from desiga is maintained: we may then be more confideat of the universal applicability of these mechanisms. 


\section{Chapter 11}

\section{Discussion}

\subsection{General Summary}

HM is an evolving growing structue, but the core of the modkl as presented here is accurate and will sol change as the modet develops. HM is a variant of classical 2 set theory, extended and interpected to sut engineering design infoenation. HM provides the iscmophisms thas permin us bo view design informatice in an objoctive, formal way. Specifically, these iscencephisms permit dexign entities to be representod by sets tha can be goupod into subsets using crineria all finding their noots in the Axion of Separatice as definod is 2F; that is, the erganizational axicens of HM (Chapter 10) are alt asiom sub-schema of the Axion of Separation.

Oher meseanchers [162.173] have surgeshed extending fomnal systems to sait design, but the author is not arave of any amenpts as detailed or well-zrounded in accepted logic systems as is HM.

HM is not intendod to autcate the design process, but rather to provide a seructerad notacion that makes infoemation about design entities cleares and bus permits the designer to anoly whatever thought processes he/alx prefers. The author penveives the desigaer as existing ln a symbiocic nelatioeship with desiga nools soch as HM, naher thon being roplaced by them.

HM is based on a fenctiond model of the enpinecring design process that vicus decign information as separaie from the various poocesses that act en this infornasion daritg the course of design develogment. 
The key issue that pernits HM to be stated at all is that dewein the universe of discourse of ZF is restrictod $10 \mathrm{omly}$ those entities pertinen 10 design. In this way, we can make more specific statenents (i.e. axicas) than $Z F$ alone permick.

The asioms of $\mathrm{Z}$ - are not abteded by HM, and no new primitivec, cennectives and quantifien ace introduced. For these neasoes, we are asvared that HM represeres a valid, corsistent fornal system of logic [N0) (with respect to set theory). specifically geared to design information.

Objocts ace sets of antributes, and capoure neaningfut information about design entities. This powides a nopural form of expecsion for design infomation because objocts afe conceptually equivalent to the entities they model. Attribuses are defined in terms of bonains and neges: domains of attributes in HM include scneralined Simensons of measareanent. Views permit objects to be partitioend acconding to criteria specific to particular design tack. Relations and functions ate used wo define general classes of eperaves en objocts, and provide a flexible, eatensible mechanism foe the begical nepresentatios of various kinds of relationships and constraints. The spocific relakiondeips of structural similarity, functional similarity, ageregation, specialiration, and genenlization art all captused forasilly by HM.

Since HM applies wo different design tasks, such as solid modeling, analysik, and so we if preseris

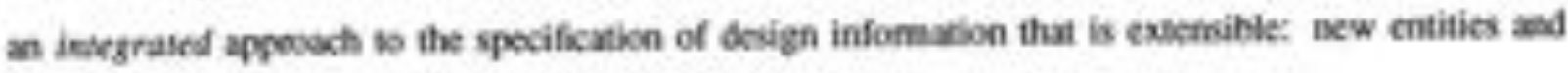
relationships can be specifiod using the model without alvering the model itself.

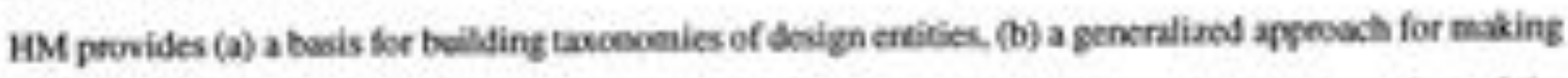
statements about design entities independest of how the entistes were genented fic. independent of the design process used bo create them) and (c) a formal syntactic notatice for the standarflizatios of design entity specification.

\subsection{Future Work}

There ane various fronts on which work on HM ean coetinoc. The wie of coestraints in the hybrid model nust be cxamingt, and saitable thoog generated. A review of the curnent literature indicates that relatively little work has been done in this anca. This may be because the desien entities that are constrainod have been vaguely ansor imprecisely defined in the past. The foenal undentanding of these entinies provided 
by HM may aliw help es understand the cueduraint sacidactioe pooblen betier.

Classification of designentites by flanction is another anea where cument undentanding can be imptoved; enphacis will be placed on this in the fature work of the author.

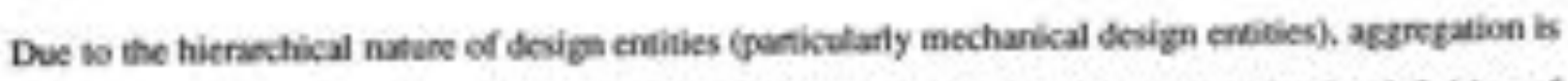
a key absiraction mechavism. Further study of the A prodicales that IEM suppons for the defitition of aberegates is warrated.

A the thocectical level, a fornal thory of design information will be auseful vool for the stady ef the desiga process itself by providing a uniform lexicen and grammar for information specification. The author noces that it is possible 60 blend $Z$ and first onder prodicale calcules $[99]$. The peodicate calculus is the formal hasis of sucla tooks as expert and knos ledge processing sysacms. Also, farry logic [147. 148, 174] presents a urique oppontutity for representing the notion of uncertainsy in puncly foemal uenns. It is interesting to specaluse en the ranare of the combination of these tools with HM, and their possible acplications to desigh theory.

At a nowe practical level, applicasion of the thoon to real devign ervimenacnits has the petential bo improve communications between desipers by providing a common vocabulary, 60 askitu in the standardieation ef desiga specificatioes, and 60 kad 60 sew and more pewerful softwase sools 60 aid the designer. The latter avenue is exploobd in the nesr Part of this Socunern. 


\section{Part IV}

\section{ENGINEERING COMPUTATION}




\section{Chapter 12}

\section{Introduction}

The wok presented thus far has bech quite abdinct. This has been nocescary because littic fundvenenial work exists is the asea. Because of its alotract noure, practical applikatices of the author's work may secm difficult to idernify, In ender to atdress this pooblem, the auther has includod a major application: the impact of HM on esgincerine computine Tac irbetion is to exicnd the perspective afforded by HM into mort practical issues of computation in dedign eminonacnts. In particular, a softwast system developed by the auhor, callod Desikavrs, will be prescniod and discussed as a demonstration of the gains that cas be expectod from the application of formal iechniques.

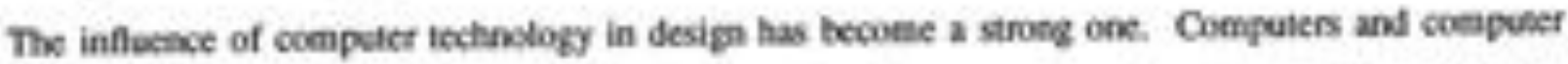
software systems are used in every aspoct of the engincering enterplise, from conswent engineering. to CAD and analysis, simulation, nanufacturing and poodection, and marketing. Although some may argue that this dependonce is soetielsow detrimerial so the profession of engineering, there is linte doubs

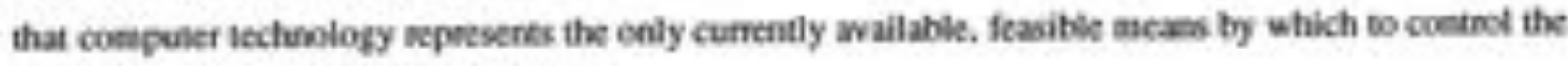
complesity of the engineering enterprise.

The Information Revelutice the wodd is currently experiencing is relased to its prodocoswr, the Indusirial Revolution. "By dramatically rofucing the costs of coostinatins and increading its specd and qualiny. these new fisbonasion] nechnologies will enable people to coosfinate more effectivelys, to do much more coondination and to form new ceondination-intensive busiacss structeres [18]." Cocelination, in this case, is the ahility to organize, or onder, what we do, and the informasion we ese to do it. One of the principal 


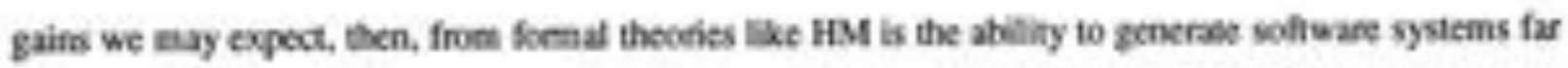
moee capoble than existing enes 10 asolst designers in their work. Indecd, successful software systems based on fomal theories can provide a stong indication of the saitability of the thoories themselves.

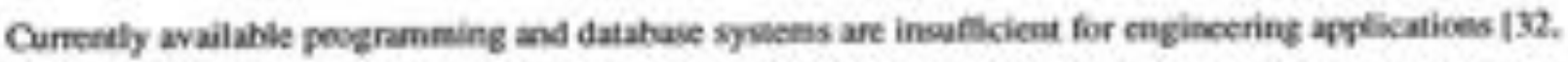
42) The high degree of complexity of modem desiga antifack. the richness of the mumber and kinds

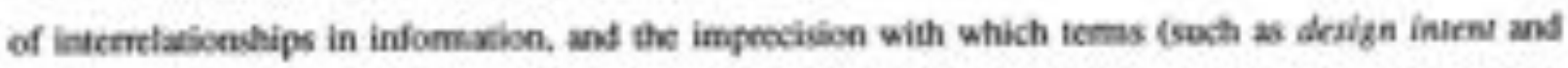
fuectional descripulon) afe used have all corknibuled to this peoblem. Today's cortinuing and ever: increasing rate of new engineering softwiee developmeat makes it evident that these issoes have not yet ben adressod popperty.

As well, there have been a cuaber of argamens made recently is farof of a "language-based approach" to design ( e.e. [162, 175]). Such an approach enails the development of languages that permit the expescion of design iefomation in a coenpotational emironenent that do not tie the user to a sinele methodobegy er solution toctaique. In this way, relatively smalt languages can permit the capture of

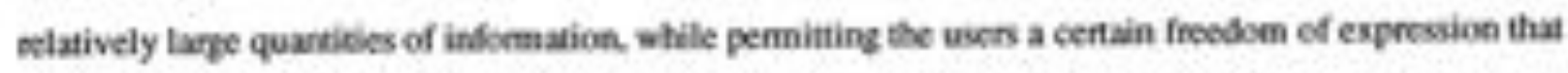
would be mitsing if a procise mothodology had been specifled. The auther's aperouch throughout the werk pescriod bereia has been wo separate information from procedsers the use the information. at both the thooretical and practical levels. The language-baved appoosh, then is quile sympathetic to the author's specoch and the programating language wo be described is this Pan may be regastod as a contribusion to such larguage-bused reseanch in design.

The interent complexity and relatively ad hoc nature of the design enterpilse can overwheles even the nost pewerful syatems. In order to cueabat thik, engineering softwaft developers and mecartien have

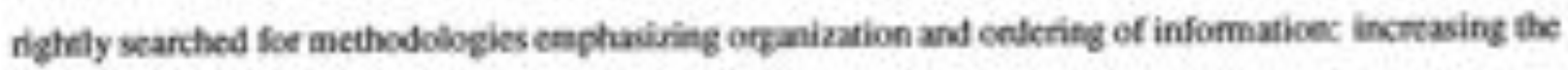
degroe of orgatiration in a colloction of ieformation makes it moer accesible, more concise and less Exely to be a sonece of emor for sesigners. However, the exact nobure of the orfanizational foms that would best sait the enginetring enteprise in zeneral have 10 date elofed discovery.

One problem not adfresced in ober curnent research in this area is that of goncral enginecring computing 11731. Not since the creation of Fonran has a lageage beeh tageted inientionally for use by engineens (with the poscible exoeption of Ada, whose suceess in this area has yet to be peoven). Condidering the great evolution that has cecarsod in design, it is not varprising than Fortra is unable 00 aneet the 
programming reyulnements of modem engineering enterprises. Given the high degree of complexity of Sevign information, it is important that the paratigm match the coectptual model of the user.

In oeder to motivale the arzunents peesented in this work, we shall begin by examining the relationship betwen software sysems and engincering in an ahdract way. This will permit ws to distinguish between the seneral exigencies ef enginecring computing and the requirements of particular softwafe systems.

The domwin of a wotware system is the cellection of the kinds of problems to which the system can be applied. The softwane sydem maistains an istemal computational modet of its domain; that is, the system is a manifosusion of this model. This domain-sjecific ecmputational model is a unification of a formal coeceptual model plus a general modet of coenperution. For example, ocentinum mechatic and nathemaics provide a fornal model foe finite elemert andysis, this, combined with a programaing emironment (ahich is a manifestation of a penerd model of computation), provides the computational model for finite elemeat vefware systems.

Engineers use a sofware sycem to solve problems within the systen' \& domain, they are using the syeem's model of the problem domain to perfom a given rack. In onder to do thix, they must at least kuve scene understanding of the system's computaticenal model. This includes the formal model and alwo (unbonunately) seme aspects of the general computational model.

However, the usen also have their own mental, of cognivive, models of the pooblem doenain. If the user's model of the Somain is increnpativle with either the formal somain model irthereat in the soffware sydien of the conpulational model of the soffware system itself, an inpedance wiswasth [27] results. As the name inflies, an impodvoce mismatch orperents an efficiency loss in indomabion modeling. In this sense, the wond "efficiengy" nefen to the ability of a system (formal ar sodtuare) bo procisely and

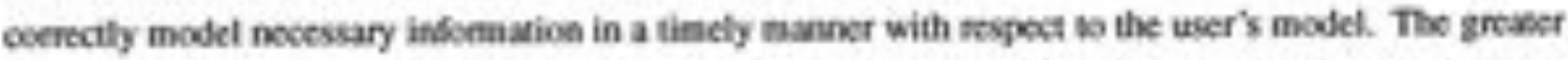
the mismanch, the kss usable the softwayt system becones, and the mote likety inefficiencies and emon. will Soninue its use.

lmpedrace mismaches betwoen the author's foemal domain model (HM) and the user's cognitive nodel ase handled by the iscunorptism described in Pan IIL. The iscmorptism provides a comerpondenoe betwoen the fomal systen and docign infoenation that efloctively climinales impedance mismathes arising foce the use of HM in a design emimonere. In this Part, the author is concensed primarily widh

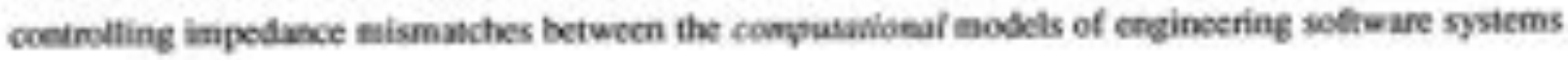


and the user's cognitive nodel.

Impotance mistanches ave not bugs. Bugs are simple mechanical emors remodiod in a refaxively staightforward way. Rexher, impedance mismatches arise fosm limitations in the programming paradigna selected for the design and implernentation of the sof wane system. These enismatches are problematic. They define fruen the outset the limits of the soffeare system's fencticeality, and guide the programmen theughout De development of the sysken. The paradign provides the concoptual tramework for general computation withila which the software will be creased. Any limitations in teis framewotk will be inherited by the sottware. If the selected parsign is incompasite with the formal nodel of the problem doenain or the users' cognitive aodel, the resulting softwase will be clamsy and error-prone, and its results will be difficult to interpret and we. But most importantly, there is no eimple solusion to this kind of impedance mismatch shees of choosing another programaing paraligm and rewriting the sofware from scrack

Cearly. then, the ivvestizuson and selection of pogramning paradigms is the key bo coetrolling mismanches and imporing the qualiny of software systems. Eaginecring rescaschers, as esperts in the poblen demain for which suitable solferart systems aee so be developod are Eely candidates bo be able 60 carry out such inveutigations successfully.

The author expects that sucoescfel efforts will bring to existence entirely eew poogramming paradigas evolved from existing ones, but siprificantly differat in the computationd modets they suppon. These models will be basod on formal theories aboet dexign that are cancinly under developesent by many differene researchers, thus providirg coetineity of fomal rigor from the domain model through os the implemetaraion of support softwae. The design theories will powide the nectsary fomal backpround. and the computasional models will peovide the bridge from the pusely thecetic woeld to the softwate sysaems that will be able os adterss real engincering pooblcas.

In the Sections that follow, a peogramning language for drsign infoenaxion, called Dessokse, will be introduced and discussed. Desceser is an implenentatice ef a computational model basod en HM, and mast thus satisfy its axioms. Since HM describes the structure of design information without making satements about the we of that informasion, Desocacx will deal with satic data modeling enly; that is. it will deal with the representation of informusion, not wilh its matipolation. Chapeer 13 presents the eequircanents for a new computationd paradign for engincering. Based on these noquinements, these poogramming parafigms are identified as the baves of the current wok. Chapter 14 then introdeces 
cenain key notices and the basic syreatie foens of the Desscava language. Chapter is follows up with severd erumples indicating how the Desaonex linguage can capture desige informatice cfloctively and conciscly. 


\section{Chapter 13}

\section{Requirements for a New Programming}

\section{Paradigm}

Many differeat programaing paradigns have bees used to develop enginoering softwate, including functicenal, logic, impentive, objoct odontod, and nilational [176-178]; none have sucoecdod univtrally. The lates anemper, and those showing the moet proetise. are those that blend rwo or more paraligns. This is because each paraligm abone eppesents a particular projection of the "real" world to that ef computation, that is, each paratigm performs only eertain clases of computations very well, and in their purest foens do so fo the crelasion of other kinds of coenjulation. Although there are many problem domains where one paradigm akene can perform well, engincering, for all its coesplexily, is not one of them. Enginetrieg pooblems can cover both numerie and gecenetric donains, both the peocisely andlytic and the numecrically appoximated, the ethereal (for example, using chaos theory ne model turtulent fluid flow) and the proctical (masufacturing srocess planning, anongst others). Clearly, an appropriate solution for the engincerifg enverprise must perfom compotations efficienily, ya femain flexible enovgh to moet its widely divergeat requirements.

Some of the roquireacnts of a new programning parsigm for engineering have alseady been mentionot. To reittrate, a candidate pandiem mast: (a) be suppenod by a fomal model of the application demain; (b) capture the complex dasa structeses typical of many enginoering appliealions; $(c)$ capeuse and maruge the rich inemelationships that exist betecen these stescures, (d) be represcntable by a formal cemputational 


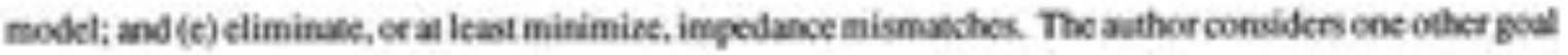

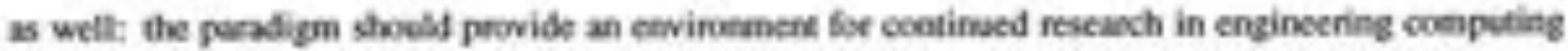
and desipn thoor:

In is noed that doe vo the current lack of formalism in engincering design, in is difficult bo expect the immodlace sativfaction of seme of dese requiechents. We can however, wse such boenaliratice as curnendly exiss, and tailor cur neselts in the fature as cur andencanding decpens. Thas fexibility beckenes another goul of the pardigm. In this coniext, Elexibility is the atilify to try new progranming and modeling wocheiques cavily withost significan alverations to existing seftwar. We may in this way substitule cur lack of foenal undentanding of design with enpinical analysis and the ability to experiment.

The wuthor has idcutificd tepe programing pardigns as being of particular relevance in engineering applicatioes: fanctiond programmine, sematic data modeling and object-oricriation. We now briefly introduce these paradigms.

\subsection{Functional Programming}

The fundamenal pandign of functional programine is that a computation can be represented by a collection of (possibly complex) operations acting en (relatively simple) data structeres. In the ideal case, no assignments ever eccur, that is, there are no variables in fenctiond peograns, only functions and consares (e.e. nambers, strings, etc.). Tsowh this afposch is very elepant from a thooretical peint of view, it does not take into actount the exigencies of practical computasion: for example, the integer 10 is ropresented in a puncly functional emvionacnt as the application of a function called succesaor

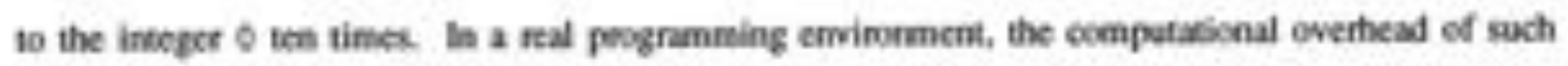
an apposoch would be confletely unacceptable. Thus, most functional languages permit at least single asslgnwent, Le, a variable cant be assigned a valoe enly once during its lifetime. One does not chanpe the value of a variable, but rather elianinates it in Goor of an entinely new variable that has the acw value assignat to it. This approach, though an accepuable coenperenise between the practical and theorctical aspects of computation. mesafts in a compuxional molet that is rother counter-intuitive and fiffecult wo use. expecially by peofle enaware of the theory of functional programmine. To offset this, nany curnenaly popular functiced languates (particularly LISP and Scheme) permit multiple assignect, but only in 
cenain controlled ways. Athough it is commonly sald that the fancticedl paradigm does not permit the capture of state, this is a reisconception. Functional prognamning cely requines thot manipulation of the state of a progran be explicit. This ensues that unwanted and eflen difficalt to identify side- wects do ace

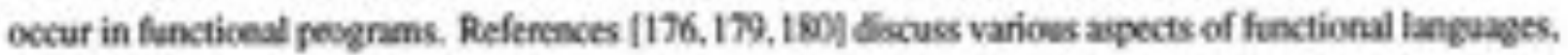
asd [181] fiscusses sone of the avarages of using the functional pardigm in engineering applications. One of the most novel idcas of the LISP family of functiond languages is that of mess-cincalaritys A

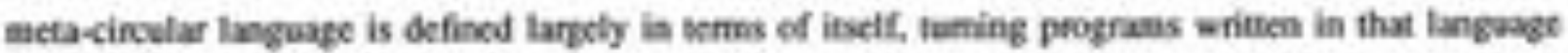

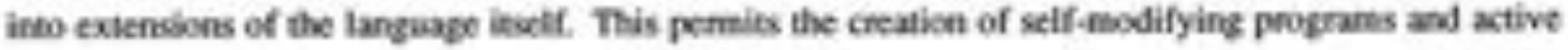
dea seructares. Meta-ciroularity also unifies the roles of peogrammer and user, it becomes easier for the "progranmer" to undersiand the eser 's aceds and for the "user" to have contod over seetware peogranmod by ehen. It alos permaies the develogment of soff ware in modala layen, all wrinen in the same language. each layer expanding upoe the capabilities of the proceding layers.

The akilify of these languages to trex proprans as dxa (i.e, petform symbolic coesputation [179]) is of particular advanage in applicasions imolving devign infomaxion modeling. We cas wrine functions that can examine design anodels and check for satisfaction of various kitsts of cominaints. The conotnines may be specife to the donain (e.g. constrining welght or size of a component in al assembly), but they may also be computationd in nasure (eg. databuse inegrity constraints, momalizason, etc). We can thus urite dushase schema and instances of those datshes (i.e models of actod design artifacts) treating thern with a single language and coencutational paradign. This further integrates the roles, and thus blurs the Exrinction, berween progranmer and ust.

The greacest advartage of foncticeal peognmming is the sound and detailed theotetical backgound upon which it rests $[99,182]$. Findly, the d-enkalus preseres a general mathemasical theory of functions, and

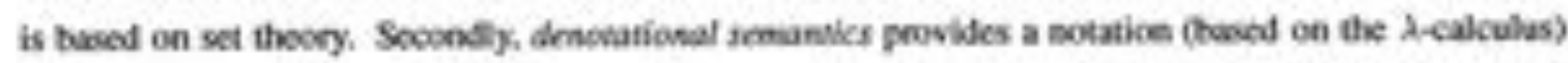
for the nepresentation and stody of computation, perminting the evaluation and napipolution of prognams as if they were alpobraic expressioes, Sach fond computational thoories provide the bridge between a formal design thoog, and the implenentatios of sothware systems based on that theory.

Alhough Scheme and LISP are rather similar, Scheme [183-185] was choien as the base langoage for Drsacaek because its semantics is definot in mach more fomal ienns than LISP: This means Scheme exhibits a higher degret of robudiness and formal rigor thas its predecessoc A particular implementation 


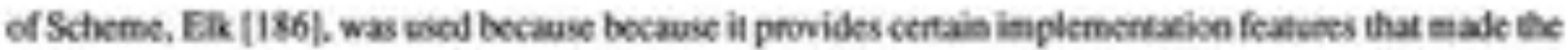

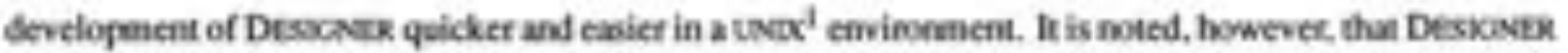
has also been ported 00 another verion of Scheme, called SCM', which is more rigorowily adheren wo the existing Schome standand [tS4] than is Elk. This indicaes coedlusively tha: Desackrs is a legitinane exterision of Scheme.

Finally, it is motewonthy that there has been soene effon $[181,187]$ to study and inplement the nosion of a dantuase based on the fanctional pardigm. The signifcant afvastage of the functiced puraligm in this area is the the coplicir managemene of progran state can nake darabase opdate managenent and nomalization easier than in conventiond approsches.

The ose notable disalvarkage of the functiond programening paradign is that coenplex dea structures ast somally not supported. This restricts the orgarisasional structurts that cas be imposed en design infomarion. However, as will be demonstrated below, this deficiency can be remediod by the use of coecepts from ebject-ersetration. Alhough recently developed functional languages (ese. ML. Hakell) have richer type systems' and dau structures, it is not yet clear how these mochanisms can be best uved in an ergineering cnvircemene. As well, the type sysiems supportod by these tangages are not necescafily coespotible with the formal devign theories they aft ineended to support. The author therefioe favors the use of a vatyped language (oke Scheme) into which eas be built whatever type infomation is found necessary.

\subsection{Semantic Data Modeling}

Sematic data modeling was originally conoeived of to pemila the creaticn and description of data schoma that would thes be coded inso relational implenentatioes (111), It presened the advantage of ignoring implementation issues in favor of achieving a decper concepted undentanding of the problest dcenain. Implemertakion issues were then dealt with using the nelational data model [108]. Eventually, it was reognized that there were application dsenairs where the acher asscentecet of abotractice mechanisas

\footnotetext{
UNGX is o andenewk of NTAT.

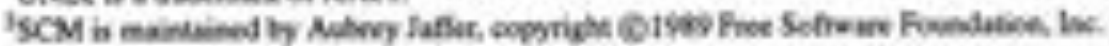

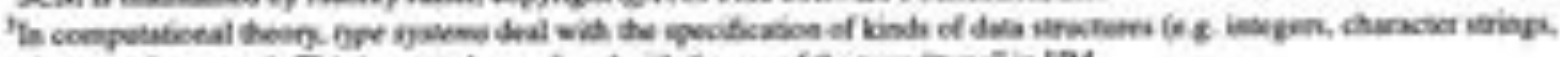

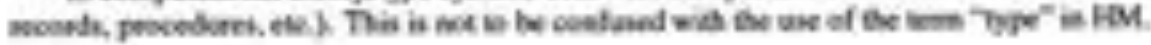


available in senantic modeling would be of greas advantage. Eaginoering was bertified as ene such dcenain. Since then, a number of differen semantic data models have been generated and inplemeraod. Two good surveys of the field ase [28.111].

Becase of the diversity of approaches taken by various seveanchers in semantic doca modeling, in is difficut wo identify key nosions represerkasive of the general approach. However, oene very relevant notion has found use in the defirition and implenentation of Desuckex, and is wenthy of note here. Antributes of dva structenes in semantic data models are regarded as functions mapping one (Evoup e0) objectis) to anceher (group of) ebject(s). This is noticeably diffenent froat the view taken in object-erienation (sec below), whercin antributes are coenmonly seen as contipuen parts of data objocts and aft thes considered mote structural than procedural. For exasple, gives scme objects modeling engines and sotse other objects modeliag faels, scmantic modeling would ocfine an atnibute used - fuel as a function mapping engine obyocts to fuel objatx, alvematively, in objoct oricnextion, an altribuse fuel would be a component of engine objocts whose values are chosen from arailyele fuel objocts.

The author has found that the senantic modeling view of atribuits is quite esefal in implemenking an objoct-orienued system within a functional languafe (6.e. Desicaek). This is particolafly linteresting because ir indicates a relationhip between two very diffenent computational paradigms (finctioeal and objoct-oriented progrnmming) by way of a data modeling system not originalty letended foe sach a purpose. Exactly hos anributes are dealt with in Desxaver will te diseussed in the Sections bo follow,

\subsection{Object-Orientation}

Oeject-orienation has had as its goal, since its efigins in the langase Sinula, the modeling of entites of inienest bo the west in a very high-level and thus usable manner [138] in echer woeks, object-orientatioe permits the creation of softwane models of "neal-world" enkifies that are very similar to the users" mental models of those entities. By defnition. then. objoct-oricntation has at leact the poterkial of minimizing inpedance mismatches it applications where the infomnation so be nodelod must be pereseated and maripulated in as straight-forward a maner as posable 127 . such as chgincering desten.

An object is generally defined as an entity that can capeure all melevast infomation about a particular Beal-word enticy. Objects encopswlate their implementation, thas making their usage entinely independent 
of how they function inemally. This frees the user from baving to understand the detalls of how the data strocturs operate. Encapoulation has been shows to poovide many afvaneges in the developecent and use of softwaet from the points of view of both conapeter science [159, 185-190] and enginetring $[25,112,191,192]$.

Coeimusication between an object and another object or a user occurs by passing messages between objocts; a mesage is a request that an ogeration be carried eut by al objoct er group of objects. Objocts can be active (dispotching messages to each other) passive (requiring an extemal agen for message dispochy), of soele mik of the twa. Similar kinds of objects can be grouped together in variovs ways, perminting ditferent ergaritrations of collectioes of objects chat teflect the foquitemens of the proelem

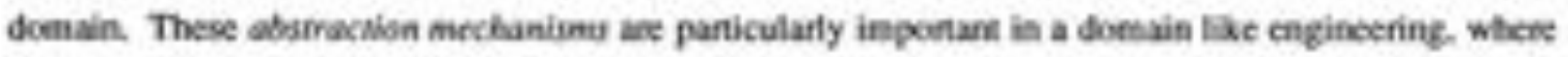
the natue of selatioschips between data can be bolk very coetelex and very important.

The greatest advariage of objoct-eciated systems is that they permit the modeling of complex, Mighly interrelatod entities (avch as those found in an enginoering environmert) in a reore simiple, flexible and elegant way than can other programming pardigns. The peinolpol dicafvarage of object-oriented sysems is that there is still no censenses en exactly what the natuse of otyocts should be; there ase so fomal models for couripoting with objocts. It should be notod. however, thas thene are a namber of on-going rescach cflorts aimed at poviding a mone formal looting for objoct-orientation (e.e. [193-195]) both as a programming peraligm and as a daribase model.

The autbor has identified thene parsneters that individaste object-oriened sechoologies. These puerneten are discussod hero insofar as scloction of aliemative approaches bused on them helpod form the overall stoctare of Distcove

\subsubsection{Message Passing Protocols}

The fint parnmeter deals with protocols for message pascling. A mocent repont by the Objoct Oriented Database Task Govup of ANS1 [196] diflerentiates betweca fwo kinds of mescage passing protosels. The fint, classioal mescage pascing. is similar to that provided by languages like SMaLtauk-30 [197] and C++ [198]. The probocol defines a particular objoct as the rocipicnt of the message. The mescage contains a seiector, which is used by the neceiver to identify a suitable peocedure (callod a method) to be ifnoked. 
Methods are defined withis ebject classes (see below), Other argumenes to the method may atwo be providod by the message. The acthod is evaluated with respect to the fectiver of the message and the result is remomed to the sender of the message.

The second form of message passing is called generaliund ee casonirol message parsing - In this probcosl, a message takes the form of a function call. These is no explicitly defined moceiver, fatet, all objects as passed as arguments and treased equally. The result of the evaluation of the message is returnod to whatever enviroement originally dispasched in.

Theclassical message pasing peotocol pennits methods to be assceiabd enly with those objects for which evaluatice of the messape is meaningful. Depending en the approach taken to define methodk, this exa impoove encapoulation asd is thus afvantageous. However, it can alvo irstoduce asyumetry in the way actions on objocts are regandod by the user.

For exanple, in SMautaux-80. be mescage 3 + 4 is evaluxid as follows; the objot iscetifiod as 3 is sem the expescion + 4; a method associaned with the appopriate class of objocts is identifed based en the nociver (in this case, integer addition) and evaluaiod by taking the value of the arguenent (4) and adding it to the value of the reoeiver. Now, if we had pervioudy definod $x-3$ and $y-4$, evaluation of the message $x+y$ would revalt is $x$ taking the value 7 , while $y$ 's value remained 4 . The asymetry is manifested in the diffewere noles plaged by the two serme $x$ and $y$ : although they would comeationally be condidened equivalent in that they beth simply represeni values, claseical message pasing causes the sole $\alpha x$ to be active and that of $y$ to be passive. This asyametry can boome confusing. especially in more complicated cases ppical in design. Furthemore, classical message passing casess side-eflects; that is, the change in the value of $\mathrm{x}$ is an implich change in the state of the poogran that is uncontroltable by the user. The exislence of side-effects can peevent verification of sodferane models of design entities; they are thes detrimenral to the coestructice of relicuble software systems.

On the ether hand, the cancical mexcage pasing postocol would evaluase $x+y$ by uaing the function + to create a new object whose value is the sem of the aryunents. This forn eliminases the asymmetry and appeals to the intuition moes than the classical fome. The fenctice is net beund firectly to a type or class of object. Though this may be seen as a violation of encaproulatice (i.e, be function is not delnod within an object class), tectuiques exist to- offset this loss whlle mairtaining the abvantages of the classical form. These 1echniques will be Siscussed below in corjunction with the doscripoion of Dessover. 
Finally, the curneical messape passing protocel eliminates the noquirement for the special meta-variable self, which refers wo the receiver of a message. In the classical pecocol, methods ane atrached to cbject classes; there is no way to detennine a-priori which particular object will huve to evalease a given method in response to a message. Therefioe, thene is no apviari way to idcntify the receiver of a message. To circuravent this pobblom, nesearchers use a special variable coemonly named self which, at any point in a computation, ifentifies the recelver of the curnealy active method. The pooblem is that seVlis an inhereatly self-refercatial structurt, and mokes verification ef poograms and software models very defficuli. Since the caroetical message passing probocol does an explicitly associate methods with objocts or object clases, thene is no noed for this special variable, and we are spared a greas deal of complexity.

\subsubsection{Abetraction Mechanisms}

The scoond issue regands the ahuraction mechasisms used so growp objects. There are two abutraction mocharisms corrently coenpeting as the principul etechanisn foe this purpose classes and proworpes. They are both based on grouping objocts by similarities in their propenties. Gienerally knowa as "classificatice" of "typing", Eis mochanion is also a basis of human cogritive functice in peract, and is

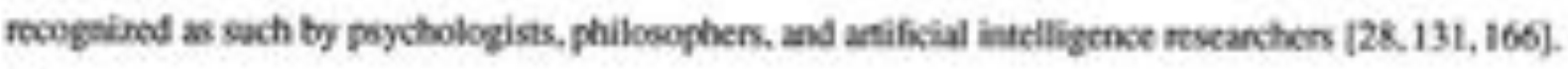

Casses are the ollet of the two forms, and ave used in such languages as 5veutaLX-90 and Ct+. They define the structure and behavior of colloctions of objocts. Classes are more ahotract entities than are objects: He lamer deveribe real critics to be modeled, whereas the former deseribe the cojects themselves. They aft comanorly dealt with using the same syneactic foms as plain objects (instancesh but have significantly different semantics.

Pootypes, on the other hand, are plain ebjects that are used as templates to create odker objocts. They aoe etinely different from classes becwuse classes ase nofe abstract modeling entities than objocts, whereas any object may be a peototype. Thus, the same syntax and scmantics can be used uniformly thoughout prototype-bancd systems.

Prototype-based languages hwe the petential to replace class-based systems as the standaed foe objoct. erieated poogramming because polofype-havod computational models are simpler than class-based cees, but setain the full expressive power of the latter [199]. 
There are problems with class-bused systens that ane deall with beter by prototypes, especially in engineering computing. Firstly, schesa - er meta-dxa - evolutica is onthogond no the developenest of objocts in class-bused systems, because classes and their instunce objecs are of different degroes of atstraction. In prototypeodsed systems, these is no oethoponality. This simplificasion can be of grest asidence especially in enginecring, where reliwionahips ate alfeady complex without the added requirenents of diflerent orthogoed systents for dana and meta-dea. Socondly, version contaod, which is very important in maintaining accurne hisceties of designs. is grtatly simplifed in poctotype-based systems. nintlly. ene-of-a-kind modeling of design antifacts is much mofe straiple-forwand esing probotypes, since thene is

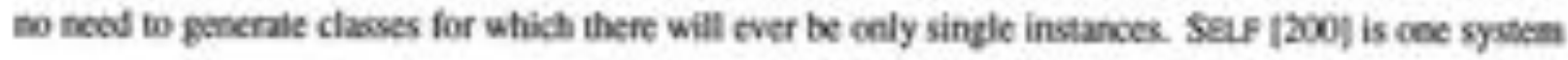
that has boen demoeotrasod to provide poentially all of the benefits of classes while maintaining the higher fesibility associated with proestypes.

\subsubsection{Hierarchical Construction of Objects}

The final issue that distinguishes various objoct-otieneod languages is the manner by which hicranchies of objects art controctid. Again. thert aro two principal aliematives. In interinaser, given a message, the comesponding method is seanthed for and used by the recelver in the evaluatioe process. The criterion upon which the seach pocess is bused depends on prescrited relations betwees vasious object classes. Oee class interiss foum a superelass if its invances respond to alt the mescages to which instances of the super-class alve respond. In ceter wonds, the noceiver of a mesape in interitance-bused syscents evaluates methods thas have been kecalod in other objocts.

Delegantan, en the oher hand, ean be viewed as mescage trasformation given a ctrain mescagt, the delegation consiructs and tracanits a new messape based on the given cne. The new mescape replaces the onginal and is re-dispatched in is plact. Thus in delegation-based systems, the rooiver object is

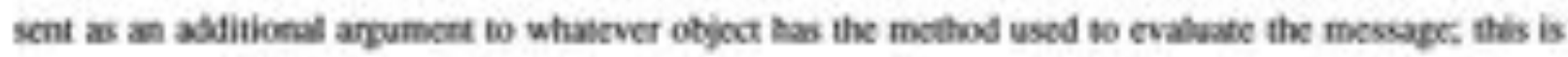
the convense of what hopoes in inheritance-based systems. In general, interitance is used in class-bused

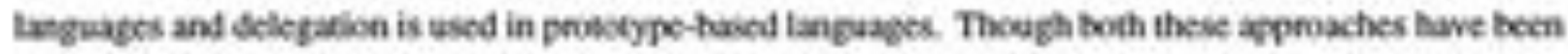
used in varioss language implementations 10 date, neither has shown maked advantages ever the oher. 


\title{
13.4 Combining Object-Orientation and Functional Programming
}

\begin{abstract}
Alhough functicnal programming and ebject-oricnted poogramaning aft eftes considcted to be at epposite ends of the languape spectrum, it is interesting to noee that many functional languages have had object. based of ebject-enented exactsions for sone time. Scherne (and LISP) have both been uod to gererate objoct-oriented systcms [201-206], but almost all these sysiems have been class-based. Some systems (e.e. 1207$)$ have supponod prototypes rather than, of is asdition to, clases, but none of these effons capture the incention of a systen that would be useful foe design. They ate general purpese programing langages of platioens for language reseasch, and 100 primitive to be applied to formal design theories such as HM.
\end{abstract}

It may be arguos that a distinct sinilasity exists befween the thevectical notions of an object and a clonure [208). A closuse is a dea strocture often used in fanctional programming to repecsent the exnjukction of a function with an envinonetent, poovising valoes for any variables of identifiers net etherwise defined within the function itself. Both objects and closunes ase crapable of capturing the sare of a computation. Altwough this simillatity is quite evident, it is not sufficient to complesely unify the two poogramming paradiens. Howeves, it is a good sign, and inticavive of poovitilities fos secesc.

One distinct difference between functional and object-oriented pogramming that nust be recenciled in any anempe to merge the two is the issue of staxic versus dynamic soope. In stakic sooping. values for variables may be ifentified by sarie lexical analyois of the progran seu. This means that the covironment used to evaluste a given function is the cavifoement that was cursen when the function was definnd, In dynamically sooped systems, the emvinonent esod is evaluase a fanction is that which exises when the function is cailed. Arguably, functional peogramening is at its best in a statically sooged sysoon [176].

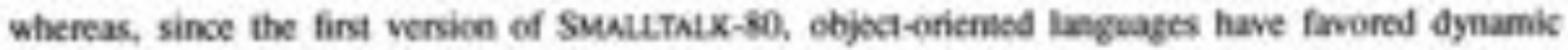
scoping. Varlous approaches have becn sugestod in the liferatuse [176,201,209]; a definitive solusion to the problem boes not apprar bo exist get. The authe' 's approach tabes advantage of multiple ascignticnt in Scheme so powide the miaimal dynamic secpe needed so suppon encapoulation of state. It is inectesting to note, however, that the fint ebject-eriented language, Simula, wed static rather than dyramic sevpe 12001. 


\subsection{Summary}

This Chapter has introduced the requirements for a new programeing paradigat for design, and identised

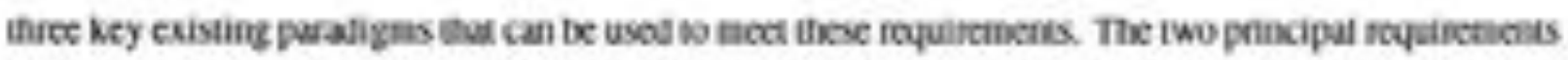
art: that the parosign model Ecsign information is as dirtct amanner as possible ( 90 as 50 eliminate or at leas minkimize inpedance mistauches), and thar fomal rigor be mainained as far as possible between the fomal domain model (HM) and the implementation of the programming paraligm as a real compulerixed bool. Objectedeneation provides the modeling constructs neoded to meet the first requirement, while functional programming provides the degree of fomalization needed bo meet the second nequinement. Alsa, notions from semaric dara modeling povide a unique, expressive and efficiene mechunism for the trearment of aneributes (as defined in HM) within a coenpataional framence. 


\section{Chapter 14}

\section{Concepts and Forms in Designer}

This Chaper introfuces the key notices and syntactic fonts of Drsocaer, a poototype-bused ebjectoriented language inplemented in Scheme. The primary goal of this exposition is so demonstrate (a) how object -oriented and functional programming can be eflectively combined, and (b) thor there are significant atvatages in the use of formal tools to design and beild soliwate systems for engincering applications. Only the principal Desiover forms will be introfuced in this Chaper. Other. ankillary forms will be introbuced in the nex Chaper as required for the various exanples.

In sefier 60 avoid circelafity within the definition of Drsacser, a dintinction is made between actions of ebjects, and actions en objocts. This distinction prevents the definiticen of Desscaser from being self-feferential. Since Dessoner is meant to satisfy HM. which is not self-referential, it too mest noe be self-pefenential.

Actioes of ebjects are the eperaions they ae meat to cany oul. Requests for such operations take the form of ressages. Actions en objects exest a a dillerent degree of abstractionc in Desscask. these actions are eaptured by regular Seteme fusctions. 


\subsection{Syntactic Conventions}

Since Desicner is an exiention of Scheme, ît obeys Scheme's syntactic nules. Scheme is similar to L.ISP in that its fuxdanental sinucture is a list, denoted by values enclosed in parentheses. Functicn calls tabe the form of lists whose fint element is the nane of the function. Foe examele: $\{+34$ ) is a fanctioncall to +, with arguments 3 and 4 . In the general case, we write a kind of stalcment (Le, a form) in Desacnek using the fonex:

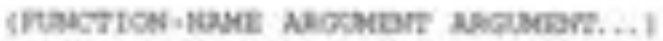

whene capitalined woeds fepresent the derotatice insended of data in those relative positions within the eall. An ellipsis $(. .$.$) indicates zero or mone items of the same kind as that immediaely preceding it.$ Thus we could generaline $[+45]$ ax:

gatro-09 mocen...

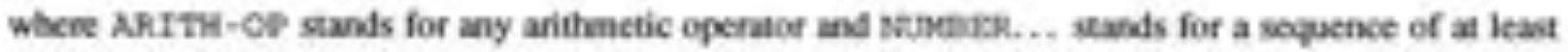
one number'.

Comments in Scheme are sarted by a sereloolon and contine to the end of the line.

\subsection{Creating Objects}

Objocts in Desxiver are mpresentations of objocts as definod is HM. A Desschek objoct is a passive store of attribubes, this treatment is in kecping with the selected messape-passing mochaniam (see Sectioe 14.6. below), the genenl philosophy of the functional paradigm, and the definition of objects in HM.

There are thee ways to create new objects in Desicark. The fint is throwh the we of gen-object:

[gen-object]

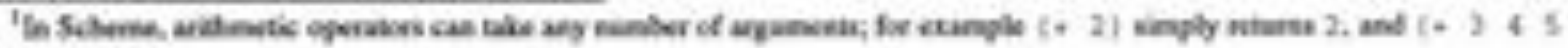
61 rebarm 18.
} 
Teis is the most prinitive object-forming function. It retums a new, empty dara structurt sepreserting an objoct. The object has no antribules, will revpont to no mesages, and is in no way nelated bo any other object. As the user's kvel, this function is of linle use however, it is at the heart of all other moer sophisticated object-Senting functions.

An object is implenterted as a vocior? costaining (a) a list of the object's atnitules, (b) a firt ef the object's pafents, and ( $C$ ) a lise of coectraint relasionohips between atriloues in that object. The noticess of parents and canstraints will be diecressed below.

Secondly, existing objects can be clened to fom tew ones uing the foen:

\{elare cavach]

The argument of elone may be any cbject. A close has all the artributes of its parewh. the object from which it was cloed. The paren is the probotype for the new object. The ambules of the new object are astomseically initialiaed to have values equal to the values of the parene's anributes, The partat/child relabionetip betwocn an objoct and its clones is simillar to the selationship betweca classes and invances in languages like SveuLsuLK-30, in that the parent poovides the iabonumion necded bo define the structure of the chilld. Ooning is generally not intended for the wiet, but can be stilined in creating hieravties of objects and quickly crtating copies of cbjocts.

The thisd way to create objecs is will the new foen:

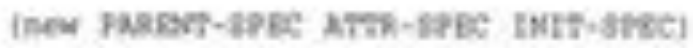

Bocause DEsKCNER is a prototype-based language without the nocbon of object classes, Ben provides the functionality to inctantiate esisting pototypes as well as the functionality no creane nea prototypes. It it: places both the class instastiation and subclassing mechanisms in conventional object-oriented languages. It is acted that new scatisfes the axioa of specialization in HM.

AMEN-SYBC is elther a single coject or a parenthesized lige of ebjects that will be the parents of the new ebject. The set of atrifules of the new object is the cartesian pooduct of the attintule sets of its

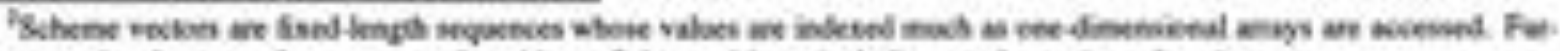

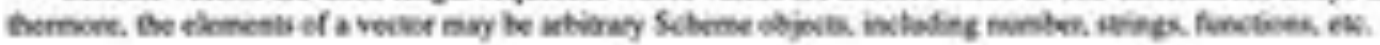


parense. Since an object can have more than oee parent, Desscivex poovides a kind of mulniple isheribance. However, the axions of specialization in HM restricts objects to be fomed only by a unioe operation of disjoint parent cbjects, that is, the parents of an object cantos share atributes.

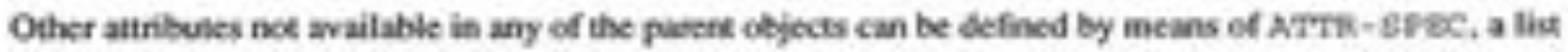
of attribute specificatioes. If ao exifa antilbubes art neoded so define a new object, an empty list. 1), must appar as the scoond angement of new. The evact symax of antribete specificailons is described in the nent Section.

Finally. Iners-SFEC is a sequence of foems providing initial atritule values. The syneas of an INTT-SPEC form ix:

Carnabure-save antrta-vaces!

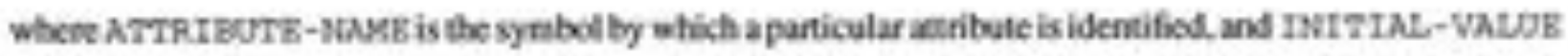
is a Deskover form that is cvaluxtod to provide the initial value of that amribute. Only those amibutes for which default values ase insufficient nood be initialinet; Aefruln values ane eaken from the parents of the cew object.

All coestraints are checked before a final value is retumed foon new.

Finally. some general manaks regarding these foms are in coder.

Wentity of ebjects is based on the comesponding axiom in MM (axiom 3). To be exact, two objects ane identical if the sets of antibunes of the objects comespond. and if the values of the members ef each comesponding pair of antibukes are cqual.

All the object-foming functions scscribed above permit at most the additios of atributes to objocts: no facility is curnenely provided for the semoval of attributes.

A clone kecps track of all of its partents. The seguence containting all parents of an objoct. all pacenes of the parents, and so on. is eallod the liscage of an object. Any objoct cocurring in the lineage of an object is referred to as an ancestor of the ebjoct. Infomarion negarsing porents of objocts is impoetare foe tao reasons. Fins, it is uiod so create attribetes ith clened objects, thus defining object sate, Second, in permits sharing procedoral information between objects of similar kinds: since an objoct krows what objects it descends from. it cae betove like its puents. 
The author has found that a prototype-basod approach can also capture the coeventional notion of object clases. In fact, the definition of a class-like object ucing only the lowilevel fanctions provided by Desicerek's pecotype syseen has been successfally implenented. This appors the notion that the poototype-baced apposach is af ence move gencral than, yet as oqually expessive ax, the class-bavod aprosch of languages like Sverutwk-80.

\subsection{Attributes}

Antributes in Drsacres ate constrainod values sered in ebjects. The constraints limiting the types of

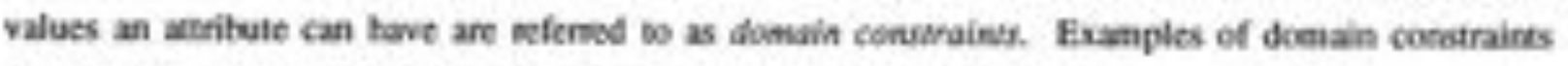
include integer? and Cubold? which are enary predicates that netam True only if their aczuments ate inesens of "Ouboids", nespectively. The domain of an atrilbule in Desionek is the set of values that satisfies the attribute's domain constraine, Amributes are identified by a rame unigue among all the antributes of an object.

Aunbutes are asded to objects when they are created, using the new fom introduced above, Antitules are defined within new by giving a spocification of its component pons using the syatax:

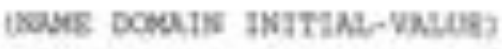

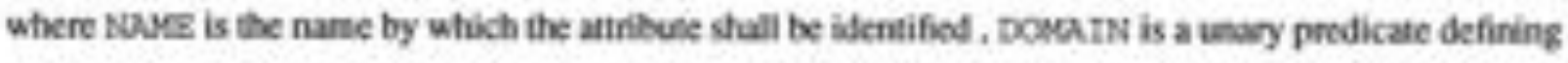
the domain condraint, and INITIAL-VALOE is an cpticnal ieitial valoe. If the initial value is omitted. the arribute is given the value no-vals a special symbot in Desioner inficating no assignmen, has been made. no-val sabisfies any constraint in Decocaex, and is intended bo differentiabe betwoes objoct creation and assignment of values so ebject attributes, Such a distinction is impontank because a wser will oflen know that a etrain object will be used, bet nay not avpiorl know esactly what the specific naruec of the objoct will be [2].

When an attriluite is defined, Desicavtk astoenatically defines a query fanction, used to query the attribvte for its value, and a semer fancrion. wed to set its value. The syetax of these two kinds of functions is piven as:

tocosy-po counct) 
A query function takes an objact as its single aryument and retums the current value of the comespoeding atribute in that object. A setier function takes an object and a valoe as its argumeres and assigns the value wo the coeresponding aribute in that ofject. Assignentent octurs if the doenala constraint is satisfied; if a domain coestrint violation ocoun, an eroor message is displayed and no assignmeta occurs.

The names of query and setter functions are based en the nane of the atribute. Nor example. creating an atribute namod length causes the crexbon of a query function named zhength and a semer function namod lengths. 2lengeh and length; will function corroctly for all objocts with an atrintuie named 1 engeth, and aft created caly cece. This crenvention does not clash with Scheme's convention of naming probicanes wid a trailine question mark, yet provides sufficient connotation to make the meaning of these functions cleat

The query and setter functions of an uttribate are eqpecentative of the atribene itself; the inglementation of atritutes in Deskasis is not visitle is the esicr. From the user's point of view, these functions are the anribute. Thus we are taking alvantago of the scmantic data model's notion of auvibusers as functional mappings betwoen ebjects.

We note finally that the setter fenction makes use of the abet | primitive in Scheme to alter the stab of

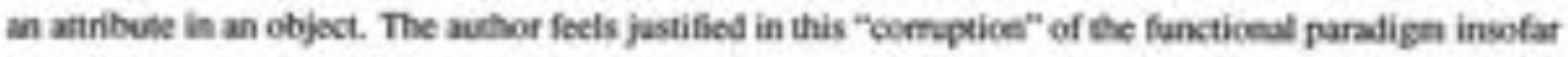
as arribute stane is anongly encapulated widin ebjocts; the side-effects are thenefore controlled by the semanties of the semer function and beyond the wach of other objocts and the weer.

\subsection{Constraints between Attributes}

Domain oonstrints on single antributes aee defined via domain predicates. Constrains can also be inposed between matry attributes in a given objoct. These constrains are relemod to as object construints, and ant defined using the following form:

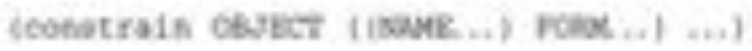


where OBJECT is the object to be constrainod. INuMe... I is a lie of the atritute names imvolved in the comtrait, and the remaining forms FObat. .. are the body of the coestraint, the evaluarion of which should retum a boolean value. To facilitate adding many constraints to a sinele object, more fhat one condrain can be given in exch constrain bom.

Object ecestricints in Dessowex are passive stectures. The is, if a coestralat is evaluated and found to be not satisfied, Desicaen will signal this fast to the user, bet will not amempt to alier the model in onder to satisfy the constnint. The author reavens that the responsibility of such alteraions should fall on either the user of some softwase sylets of a hipher level than Deskavex (e.g. a expen system, neural net, of other knowletge-based centrolling system . Desocek is mean only to capture design infomation statically, it is noe a goal-oricnied matipolatory systcm. Pus another way. Dessceex is incended to answer the questices What is this design? nather than How was ats desige crnath?

A particular ebject consuine is checked whenever an assigrment is atemped to any artribute involved in the conounine. However, the ascignenent cecun whother the objoct constrint is satisfied or not. This is acceptable dee wo the exigencies of devign. It is etien the cave that in the cowrse of a desigp process, various constraints may nct be satisfied. This is quite nomal in design [2] and does not necessanly mean the \&evign is indequate. It may be that the coestraints er the desiga prottem itself afe not well-posed. That is, in dedign, the model ef the artifact evolves as dcsign procceds, and in is nomal for there to be irstants when the model is inconsistent. These are not, and should noe be treavod as, fatal ernos, but rather as internediate steps.

\subsection{Function Overloading}

In Scheme, cee may crease and use a function without assigning the function a ponticular name. Such functions are callod anocymous functions. Overloading of function mames is achieved in Desacaer by youping a mumber of anommous functions la a lis accessible oedy to a special, generk fanction. Various definitions of the tems "everloading" and "generic fanctions" have been sagbestod in the linerature

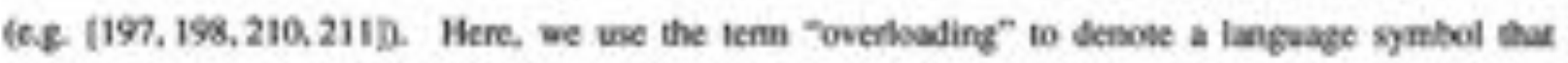
has mbltiple, mon-exclexive definitions, and "generic function" so denole a functicn that can operate saccessfally en a number of sfferent types of objocts. whene objoct types are definod by their ancestr: 
In enfer to distinguish between different anceyanows functions bound to the sane generic fanction, each ampomoes function kas associated with it a signaner indicxing the number of parameters nequind by the anonymous fanction and a (possibly conplex) predicate that is thec only for sets of acteal parancters that afe acceptable foe that anceymous function. The generic function is boend so a user-supplied name. When a generic function is called (by referring to its namej, the actual parameters ate coesparod by the system os the signateres antached to each anonymous function. The fiest anongmous funktion with a signaturt maching the actual paranctics is apclied to those parameters, and the eealting value is returnod.

Cencric functions are creacol in Dessover uing the bverlobd font:

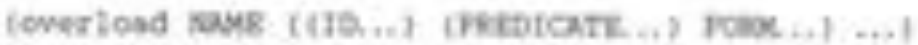

Where Wugs is the symbot to be overbaded as a generic fenctice, $(70, \ldots)$ is a list of formal perameters to be used in the definitioe of a particular anonymous fanction, and (PREDICNTR. . I is a list of prodicales that, together with the list of perancters IID. . . , form the signanure of the anonymous functice. FORK. .. is the body of the anonymous function. To facilitate writing masy overloatings of a single symbol at once, over lood ean accept mary anomymous function defirition.

By convention, nanes of zcneric fanctions begin with a colon (e.g. I volune).

Generic functions combined with object lineage information permit the sharing of fanctions that act on objects (6.e. methods in coeventional objoct-oricnted tanguapes). A signatuse may concain a predicake that checks for membership of an afgunent in the lineage ef an ebject. This is equivalent io the IS A relationship in HM and implies that the child objoct ieherits from its parene. Thus, we can cave diffesent behavions is pencrik fanctioes deponding on the ancesury of its arpuments. Examples are given in the next Section that demoecirae how this mochaniem is siailar to polymoophism in conventional object-oriented languages.

\subsection{Message Forms}

This auther has found that the croveical mescage pussing pestocol lends itself well oo implentertation in a functional exvimonesen, especially if generic functices ant used. It also maintains a single, consistent syatactic coevention foe the expessioen of both function ealls and mescages. Althogh classical message 
passing had been implemented in earlier versioes of Drsackes, the canoeical form is found to be eader wo implement, much mone efficiont, and has led wo a much more uchle system.

The cancnical form diffinishes the inportance of inheritance andor delegation. This is because it establishes methods to esist cutside abjects mather thin so be part of them. Nonecheless, the ultimate goal of inheritance and delegatice - the shariag of behavior (actions) between objects withoul requirifg the existence of ebject classes of odher tipher-eofer structurs - is actieved.

\subsection{Intentional Versus Extensional Attributes}

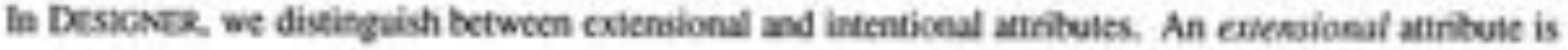
one that has an actual value assigned to it, wheseas the value of an intesilonal atiribuite is derived from the values of other antributes. Exicnsional attribstes are static that is, their values are eot procedural. They are stored within objects thenselves and are representakive of the stave of the object. Inerrional atnibuies, however, afe procelural (active) in nafure. Messages implomented with generic functions capture intensional atributes. Esamples of this ave given in the nest Section.

The author notes that in is not always ebvisus whether a particular property of a design entity should be modeled with an cxicnsional attribute or an intentional antribute. The critria foe making this decivion are beund up in the requifemerts of the design pacoss usod, and can vary widely. For example, if the weigh of a particular compenent is to he coestrained. it may be poeferable to model the component's dianensices exiensically, and its volume intentionally. However, if the corotraint is based on a restriction of space that be soesponent may take up. then it nay be poeferable to model its volume extensionally and

its dimensions inbentionally (e.s, as panameterinod functions of the volume). This indicates a relarbonibip between condraint and anribute specifications. An in-deguth study of this relaxionship is deferrod for fenure work.

\subsection{Summary}

In this Chaptes, the author has introluobd the principal nocions and syetactic foms of Desscovex, a coinpoter poogranming languape that combines objoct-orientecica in a functional programming etwifonacat 
guch that the axioens of HM anc satisfied. In this wags continuity of formal nigor is maintained fnom the logical aspects of IM through to the implementation of Drsacser itself. Though unconvertional in some regauks, the Desxcsex larguase poovides a numberof mechaniams for the direct modeling of design information in a concise manner. 


\section{Chapter 15}

\section{Examples}

Desicavex is an extension of the Scheme programmiag language, provisting a proetype-hased object system. A signaturt-based, cancnical mescube-pasking mechanism permits werlosding of fusction numes. Thus, DEssconek objects satisfy the adoms of HM while also providing centain very comeniene pogranming acthanists to increase wobilify and efficiency.

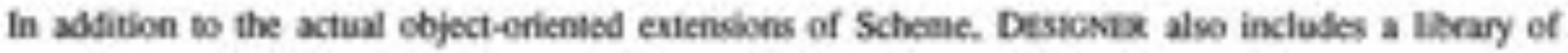

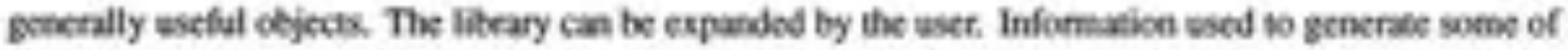
the algotithes implemented in Deskover and in tho protosppe litery was taken fruen [212-215]. The conplete soance of DEsicker and of the problype libray is given in the Appendices.

\subsection{Simple Examples}

A simple example of the definabon of two otjed pribotypes is gives in Figare 15,1.

De fint saxemeat in the exaaple defines cubo id wo be an object it is penerated by speciallinikg a single objoct, Cbfece. defised within Desscrea as the noot paren of all other objects. The statement is not a message becouse it acts on objocts. It is taken as a coevention in Desscenck that objects intended to be used as prototypes have capitalinod names (eg. Cbject, Cubofa) waile other objects have names

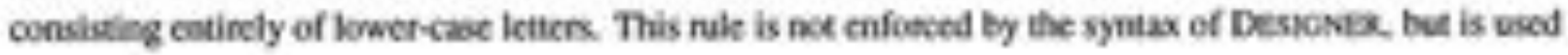




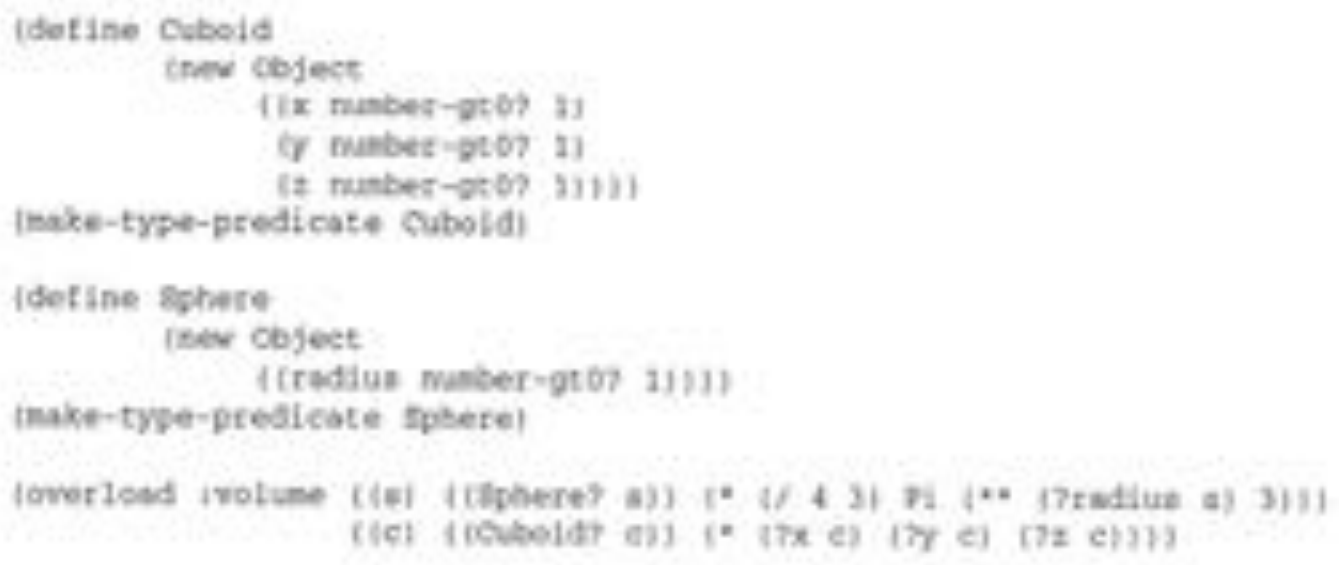

Figue IS,I: Definitioe of two Objocts.

caly to insorve madability.

Theec exuendional atrifules are then adled to Cuboid. naned $x, y$ and $z$, representing the dimessions of the entity. All three atrntules are constainat to be rumbers greser than zero by the domain specification nunber-gt 0 ? (assamine we acoept a physical dimension wo be positive and non-nefo), A default value of 1 is assignod to each attribute.

The secoed suatemene, inske-type-predieate cuboidi), crexes a perdicate Cuboid? that akes a single argement and retums True or Fatse, depending on whether the argament is an object and in ancewor of Ouboid

In the example, a sphere object is also defined, as well as a peodicate spleere?. Sphere has coc attribue neptesenting a naliss.

Next, the symbol : wolume is overloadod for both Cubo ids and Spheres. It weceps a single argumeat descroded from either Cuboid of sphere, caloulses the volume of its argument, and metams this value. This meats that any objoct clonot frue Cuboid or sphere is a valid argument. s volume is an example of an insentional attribute, that is, an attribute defined as a function of other attrilueses. Representing intentional antibutes ax functions assaes that the values of these attributes will always reflect the most recent valoes of the atribunes upon which they depend.

Deenain condraiats on estensicnal attribetes art chedket cely when new values ate about vo be assigned

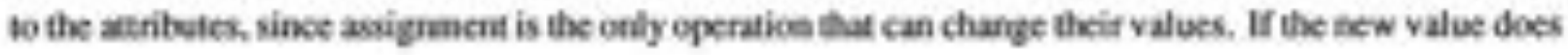


not satisfy these constrains, the assignatut does not cocur and an emor is signalled.

Constrints may alwo be imposed between atiributes in an object. For evample, if we wished to constrain the Cuboid object such that its y dinension is always twice its 2 dinension, we could wrike a consenine as in Figune 152.

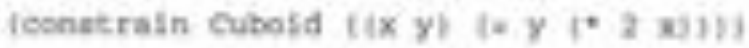

Figue 15.2: A corritaint ve Ouboid.

This objost corrurain will astoenstically be checked each time an amenpt is aade to assign values to either the $x$ or $y$ dimensions of Cubold er any object cloned from cuboid. Howeves, as discussed in the previous Section, viblasion of object constrints does not prevent asigntaent from eccurring.

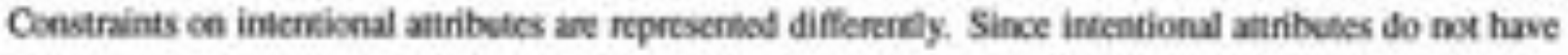
explicitly defined values and ate representod by functions of objocts, consiraints cn these antributes cocour at a different kvel of abstraction. For esample, if there wen a circumstance that required constraining a Cubot d-like object so that is volune were nos to esceed 100 units, we could use forms similar to those in Figure 15.3.

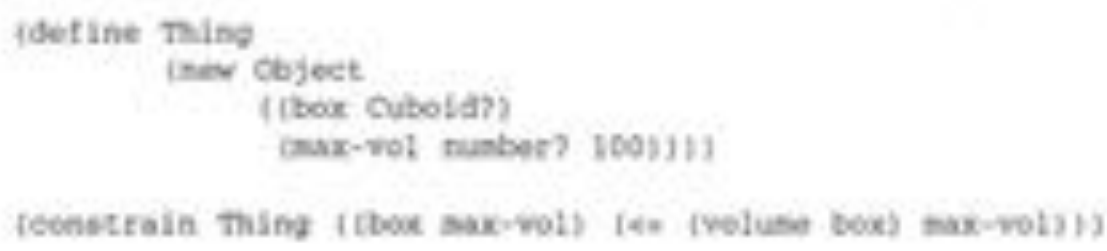

Figure 15.3: Example of constraine on ineentional autributes.

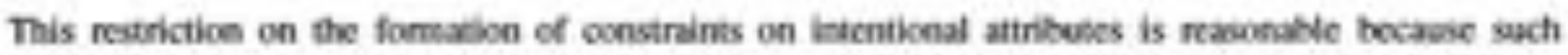
conarains anse from the inernation of objects (Sesign enkinies) wikh their ewiroment, Le obke objects with which they internct. In the example, the maximum volume is not a component of our mofel ef cuboids. It is inapsopriate, then, to embed such ocestraints within an object when they in fact model melaticenhips berween (gossilly) mary objects.

Ar ary time, the constraints ce an objoct may bechodked with the fusction check-objece = const raint s, Which takes at cbject as iss single angumene, and rewums a boolcant value inticating whether the condrains: 
ce the object's attribubes are satisfied of net.

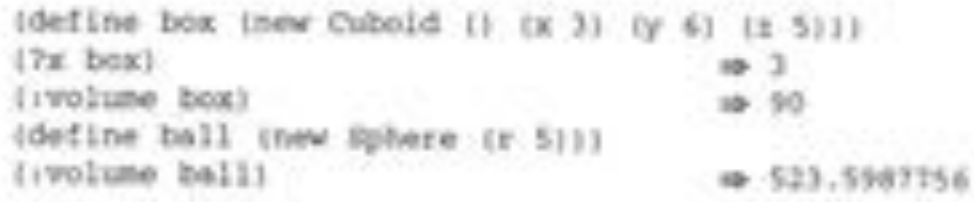

Figue 15.4: Examples of Desicaer queries and mescages.

Figue I5.4 shows examples of Descover queries and nessages. The vent following the $\Rightarrow$ symbol shous the netum value when these staterents are evalualed. The fint statcment defnes a new Cuboid object whose dimenaions are initialized to 3,6 and 5 nespetively.

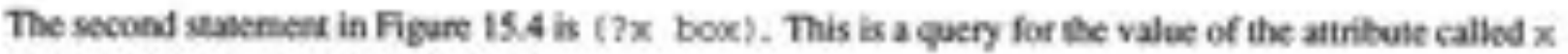
in object boo, It reterns the value 3.

The this statement shows the retricval of the cumere value of an inentional antibute of box: its volume. This is actually a message, though in foen it appears the same as a function call. Becase its single argument is a descendant of Cuboid, the anomytous function within i wolume that ntums the volume of Cuboid objects is evaleuned.

It is nowd that Cuboid and boo are both objects, and that there is no essential difference tetwoen them. In particular, eicher ene aay be usad as a prodocype for the gereration of cher objocts.

We then crtate a new sphere objoct, namod be11, with a ndius of 5 units. The wolune mescage is then evalmated again. But becase its agument descends fron Sphere this time, a different anongmous function is evaleabod.

Desacenek's ability so defise functions that act differontly depending on their arguments is simalar wo polymorptism and dynamic binding in class-basod, objoct-oricrnod languages. In the terminology of these more coaventional languapes, we sould say that volune is a mescage accepted by inotances of both Sphere and cuboid classes, but implementod by differcnt nethods in each class. 


\subsection{Multiple Inheritance}

Desscher spponts a form of multiple inkeritusct. Objects may inherit froes mone than one parent ebject. but none of the parents anay share atributes, that is, the sets of attribubes contributed by each parent must be divjoint from the sets of annbutes of all ofher parents. This restriction is imposed by HM to maintain its logical validity, Other object-enienied languags hove anempwod to support multiple inheritance of overlapping patents or classes, bet none has susceedod coaplevely, Indecd, the aushor considers the poblematic nature of managing overlapping pancents and classes in intheritance to be a clear inficabon of inconsitaency, and prefens to nestrict the posible kinds of alationships the cas be spocifiod for the sale of formal ripor.

In exter to introbluce the nosion of multiple itheritance as supponed by Deskover, we include a smalt example based on an cxample in $(210,216)$ which deals sith the concepeual moteling of vehicles, machines, and aulomobiles. Figure IS.S gives beth a graphical depiction of the model and the Dessonex, borms used to implement the appropriate prototypes.

In the eximple, Natcosobile inherits from bod Wehiele and kachine. The las thre forms are queries demcesaraing that the atribules of both parents have been passed on to hutcmobile.

Altheughene may quection the validicy of nodelitg an autcmoeile as in this crample, it is used hese enly to domonstrate the straighe-forwand nuture of the multiple inheritance mothanism provided by Desicksz, The validity of esine aultiple leheritance as in this exanple is in itself wonthy of shody; however, we defler such discussion since if does nos bear directly on the subject at hand.

\subsection{Mimicry of Classes}

Ancehcr exaaple indicating the flexibility of Desionex finclves the generation ef a class-like objoct as

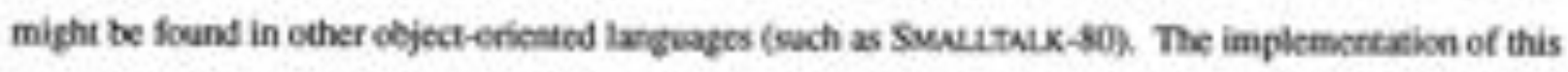
object reguires the use of the bew-level functions of Desxosers and is less thas 70 lines of code. A simple example of its use for queve objects (first-in. last-out lists) is given in Figure 15.6.

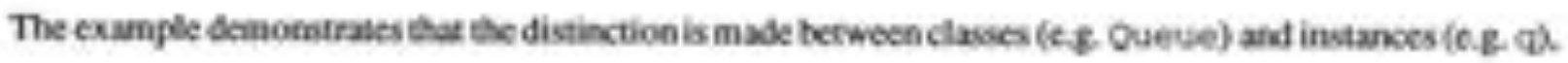



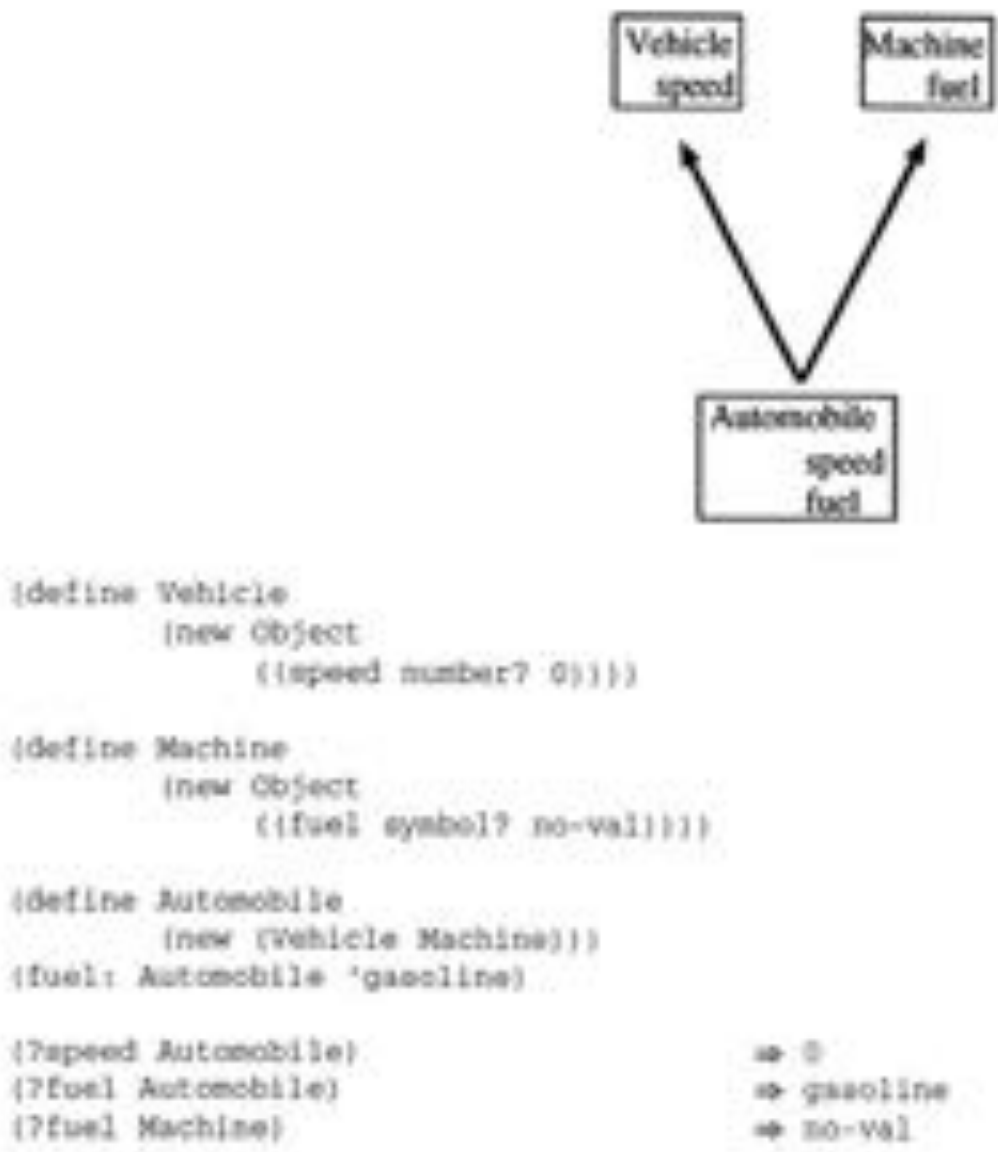

Figure 15.5: An esample of multiple inthersunce in Desicastu. 


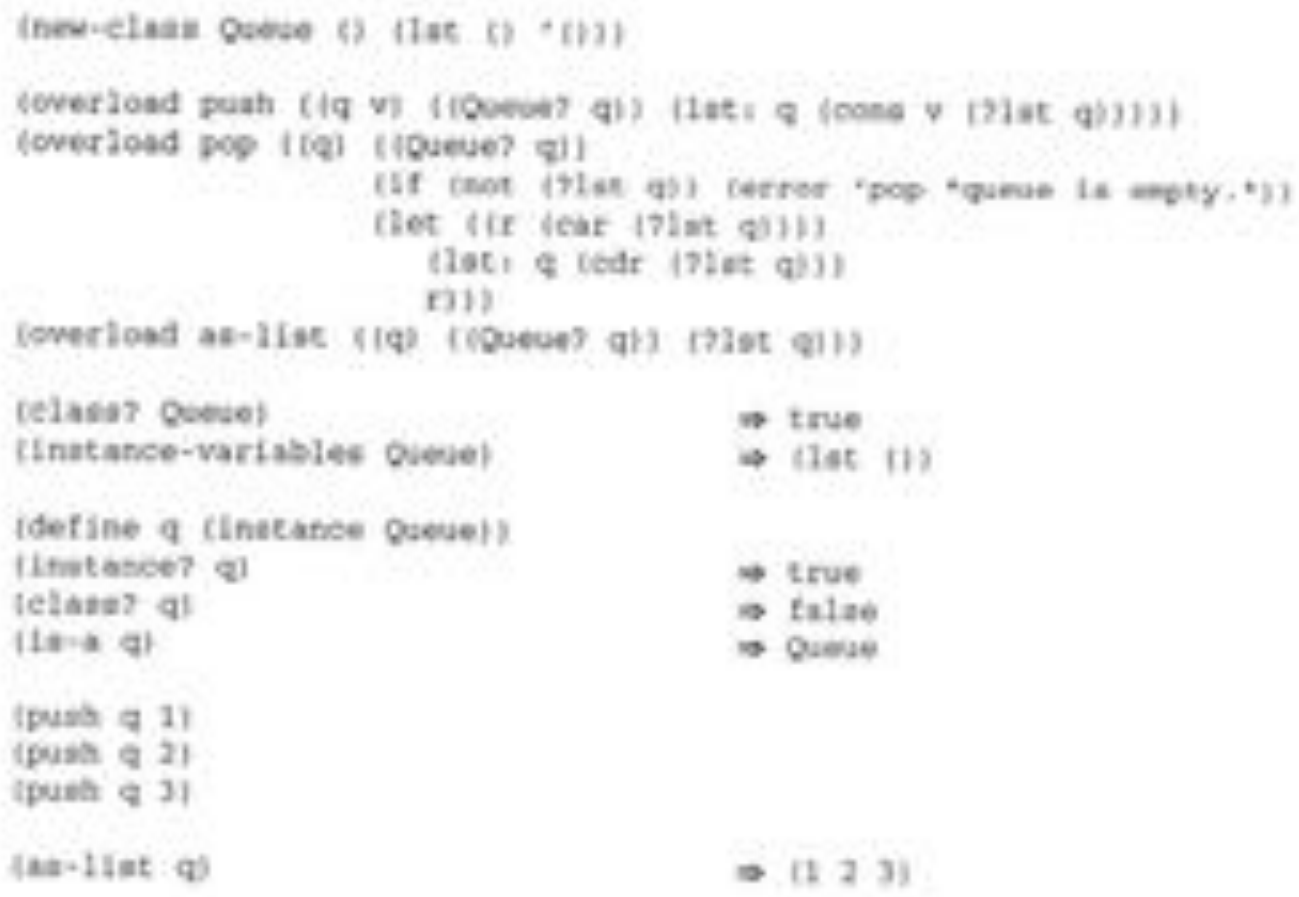

Figure 15.6: Example of use of Desicasa Class objoct.

and that the impoetam relation is - a corroctly retums the clas of an insance. Also, in the neer-class

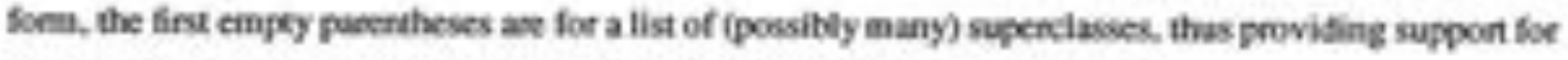
mulkiple intheritance. In this particular example, no saperclawes art spocifiod.

\subsection{Preliminary Design/Synthesis - Four-Bar Linkage}

This Section describes a more complex exartole of the kincmatic synthesis of a four-bor linkage given these precision points. The theee point synthesis sectnique wad here is taken from [34], pages 103-110.

Fipure 15.7 presents a shematic represerkation of the gocmetry of the fose-bar linkage with various objects lakelliod, and a single link with its various parts labelled. The objocts themselves are discussed below.

The four-bar linkage is modeled as an object (4bar, see Figure 15.8) with five antributec. base-a and base- $b$ an the base comections of the driver and output linbs ropectively. The atributes input. 

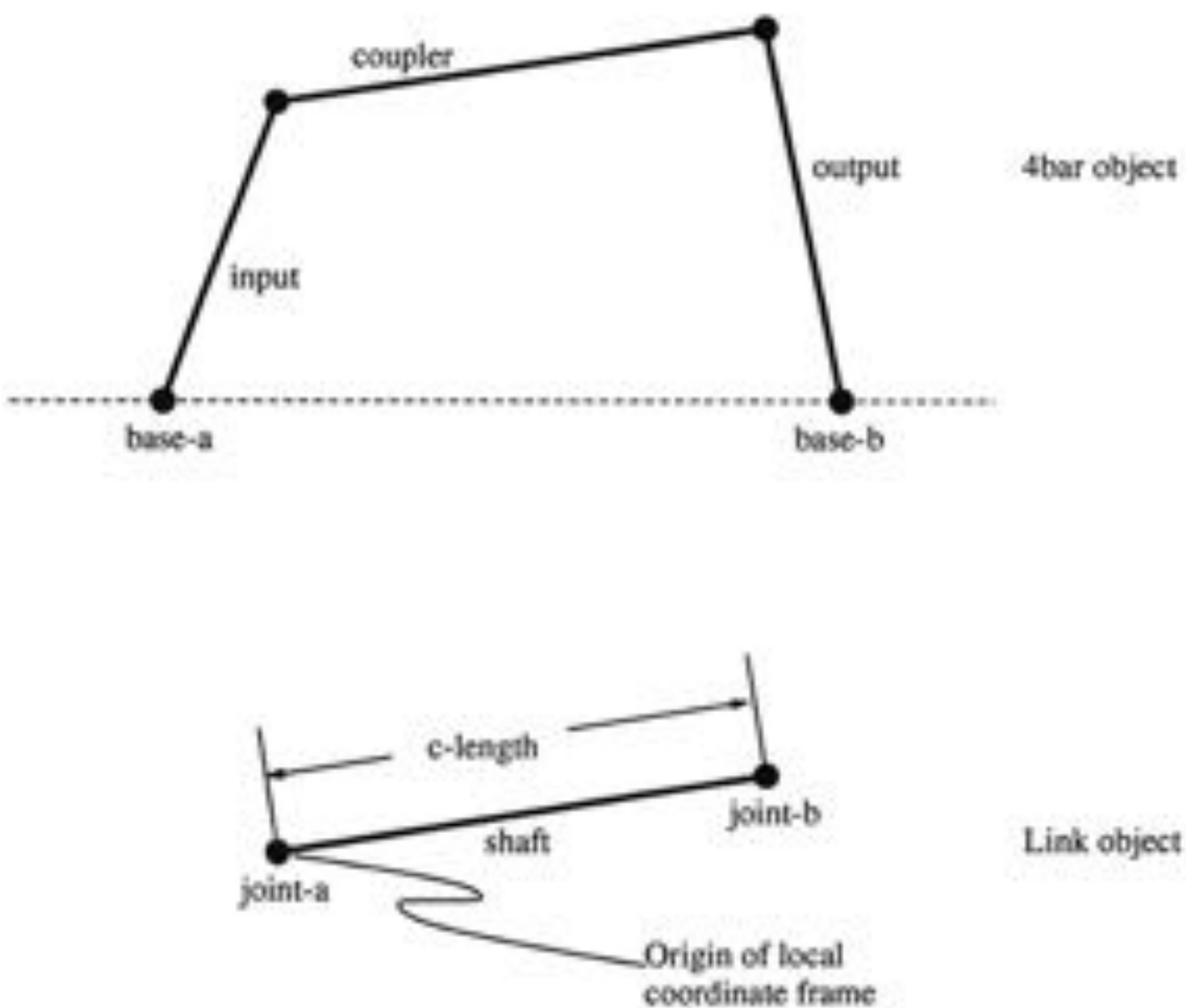

Link object

Figur 15.7; Schematic goinctry of 4bar and Liek objects. 
coupler and output model bet thoe moving links of the mochanisth.

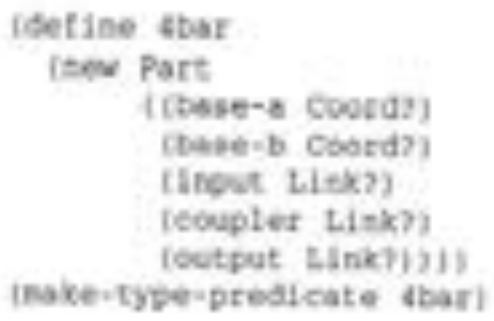

Figure 15.8: Definition of four-bar linkage object.

Oer definition of sbar depends en three ether objocts: Coord, pare and link. These ebjects ane prototypes defined in the Dessowes prototype library. Coosd models 3D points. Part represents mechanical parts; desctndants of Part may be components or assembiles, and ace ageregates of other objocts modeling a physical part's Beometric and physical propentes 6.e, maserial bype. etc.). Link is a specializarion of part specific to the developmens of the four-bar linkage model, and is defined in Figure 15.9.

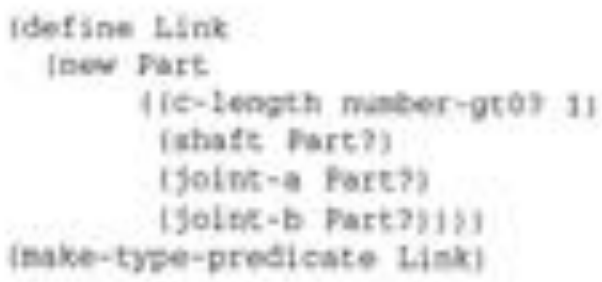

Figure 15,9: Defirition of Link objocts.

The poometry of LAnk is a complex ene which ovuld be baved en a solid model. Its amitribes include a

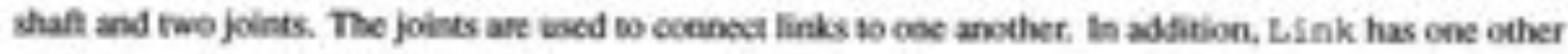
atribete: a characteristic length that sepesens the fistance from cone joint of the link wo the other. It is used as a constrain on the geemetry of the link and is generand as part of the solution of the thepe-point syruhesis tedanique. The values of the shaft and joint attributes afe no-val by default; as the actual govenctry of individual links is defined, we cas add consrains 60 Link that will assure that the gooenctric propenties of the shaft and joints maintain a relationchip defined foom the symthesis method via the link's charasteristic Iength (see Figure 15.19) 


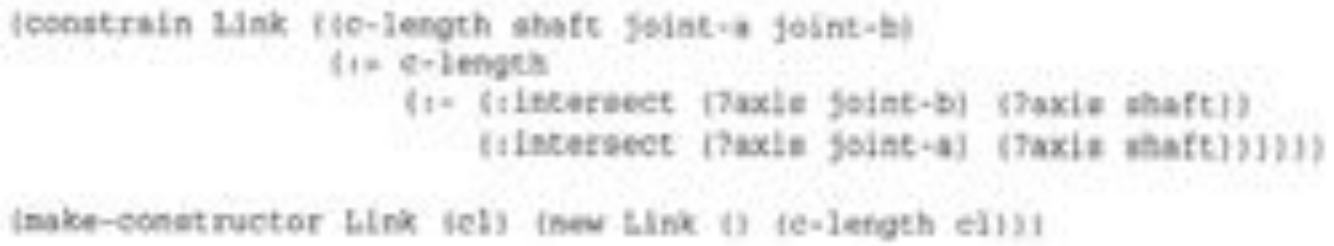

Figure IS 10 : Oovenctik constraints for Link ebjects.

The defeition of tink intoduces a new Deskinex function, make-const ruetor. This function is

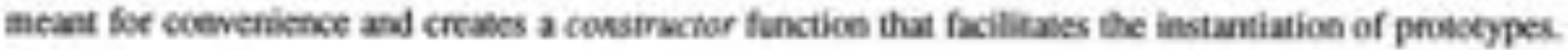
In this case, make-const ructor will create a fusction ftink that creales a new Link objoct and uses its sifgle argument to initialize the link's characteristic length. Many, though not all, peotoeypes in Desscher have conednctors sefined foe them.

The throe-point synesesis uechaique is implemened in Desackex as a method activatod by the messago (3pt-syat hest is ....) and is given in Higure 15.11.

A detailed explanation of the 3pt-synt hesis method is unnecessary here. Essentially, the bechnique wes various angular and linear displacenents of the four-bar linkage though the throe peescribed poines 10 generace enovgh information 10 creale a new 4 bar objog that satisfiss the ingut paratncters. A serios of examples taken from [34] were wed to iest the algorithm; cur resulks were nemerieally identical wo those given in the referene. The hear of the method is the las form, (nee 4 bar ....), which actually creates a clone of 4 bar and netums it.

The aubor notes that the Jpt-aynthestis method is not coverod explicilly by KM itself because it is a procedurat ecmponers of design; is is included bere as a vehicle by which design models crealed with Dexacere can be diroctly masipatued so perform useful design operations.

This mepresentation of a foenbar linkage is a panameterized model suitable for a namber of purposes. If. for example, a kinematic analysis of the foun-bar linkzge were io be perfoencd. the 4 bar objoct covld be exhended to capoure the information necded to corsirais the coenpenents of the four-bar linkage ascenbly. These constraints can bo spocifod in Deskovek with the forns in Fgere 15,12.

The base peints base-a and base-b are nos considered pan of the geoestry of the linkage itself, but peles compenenes of constraints placed en parts of the goometry, Specifically, the ends of the input 
\{everzead Jpt-byatheale

tcbe bs phliz phis pahaz garnas paiz paly)

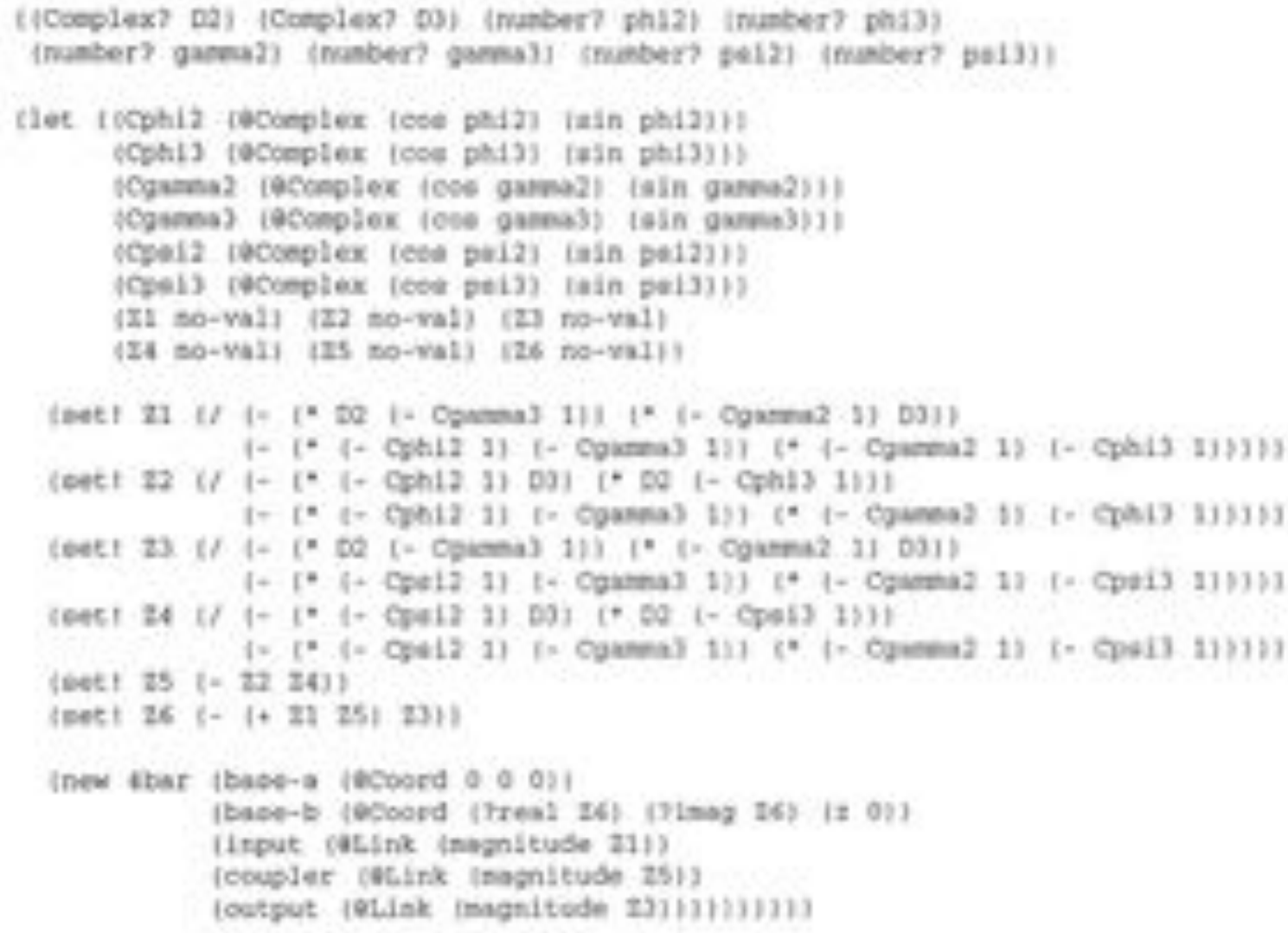

Figue 15.11: Three peint synthesis method. 


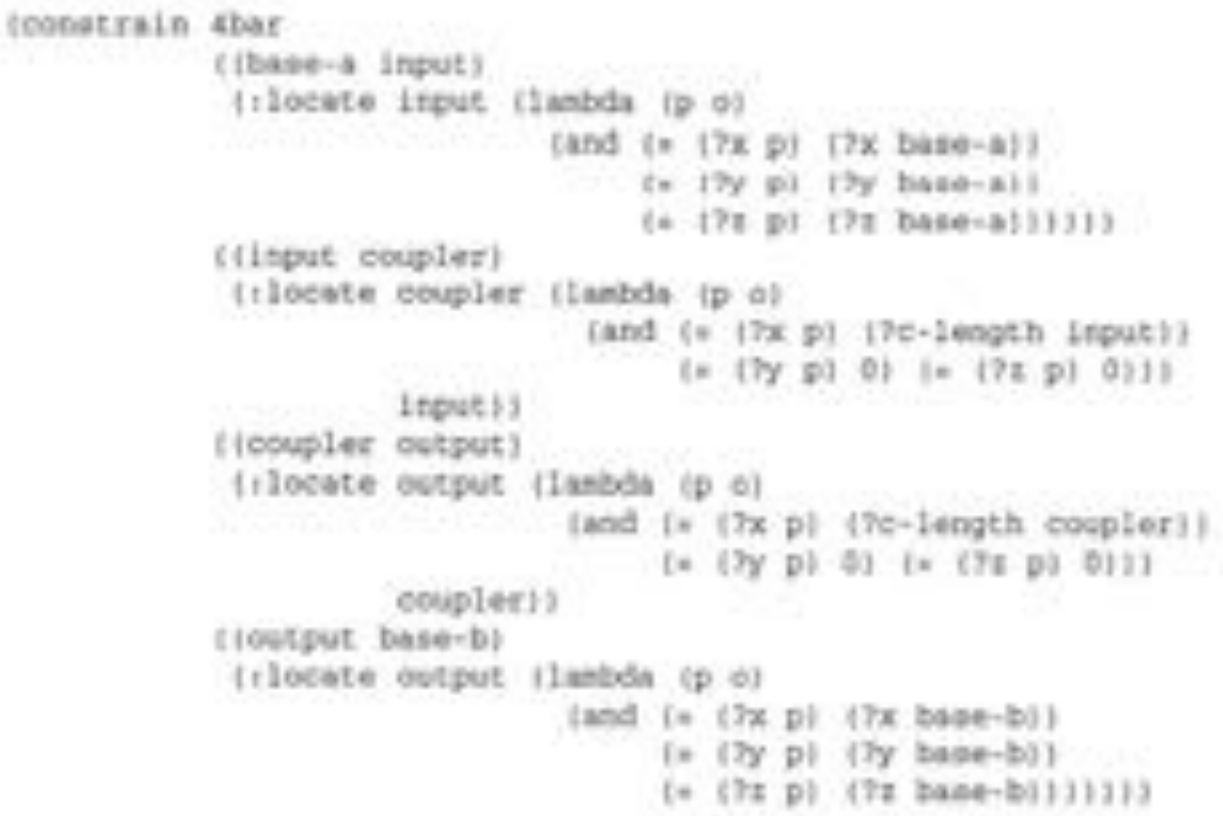

Figure 15.12: Kinematic oonstinints for 4 bar objects.

and outpot links of the fourbar linkzge are condrainod to remain at the coovtinates defined by the base

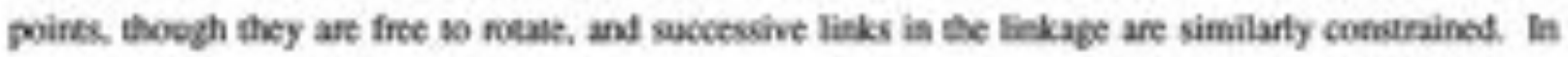
the constraint specification, bose-a, base-b, ingut, coupler and outpat refer to attributes in a tbat object; ; locate is an everloaded message to any Part that takes two or these anguments. The first argument is an attribste whose value is to be spatially constrained. The seocod argunent is a

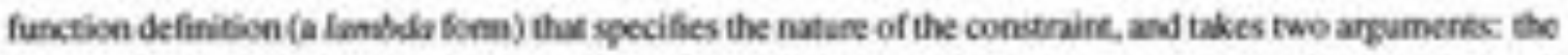
position and oricatalion of the attribute to be cominained. The opsional thind argument is another aetribute in whose coondinate frane the spotial constraint is to occut. The nopsentation of spotial cocolinates with respect to non-global cocetinate frames is reatiniscent of the relative coondinobe formulation of variational selid modeling taken by Fogle [75]; in that work, it is demoostratod that the use of relative coosdinate frates can siaplify the specification of spotial relationchips. The cumest work with Desscoves appeas to oornoborate Fogle's findingx.

The fint consraint is between the base poiet base-a and the inpot lisk; ; locate is wed bo constrain the position of feque wo map exactly to the position of base-a. The second comstrin is between the frout and coupler links, and constrains the enigin of coupter vo be at the end of input epposite 
where input is attached to base-a. In this case, the coestraint is defined will respect to the coorditute system of input. The other censtrains are similarly defined.

The 4 bar object defined berein nodels a four-bar linkage that saxiofies the inpat dara a an abotrat. conceptual level. Although the actual shyee of the links has not been defined, their ene evential pocperfy, theif characteriduic lengl, has been captared. The value of these attribubes bookne constraints on the actual gocenetries of the links.

This example demenverates that Deskover is capoble of more than jast modeling design artifacts thenselves; it provides the means to capture inbormation about the entine design. For exanaple, the 3pt- Eynt hes $1 \mathrm{~s}$ method defines a relationship between the fusctional requirements of a four-bar linkage, and the key design parameters that define the plosical selution. This indieates that Desucker can represent the relarionship between functional requirements of a design pooblem specifereion and the physical paraneters that define a soletion. Specifications erpressed as generie functices acting en objects defixe nelatiocehips between the roquipenents of a devign artifact and the objocts themselves capture key design parameters that define the physical selution, This indicates that Desicsex can sepresent the selationchip betwetn functional roquirtments of a design problem specification and the physical parameters that define a sobution.

\subsection{Hierarchical Organization - Thermal Analysis of a Wall}

This final esample shall focus en the erganization of design information with Desicers. Specifeally, we stall present (a) a parameterined model of a wall, and (b) a represcntation of steady state heat flow for the wall model. This examplo is inspirod by the mattrid in [97). It is nolod heve as the oatset that the model peesented below is not the osly way one could represent a wall in Deskavis; this particular model was chosen because (a) it matched the author's cognitive model of walls and (b) it is sufficient for demoestrabion purposes in this bocuscent.

Throughout the following iext. the veader may nfer to Figute 15.13 , this figue depicts graphically the strustere of the wall model, inclubing all objects as well as all intheritance and aggregation felationehips. 


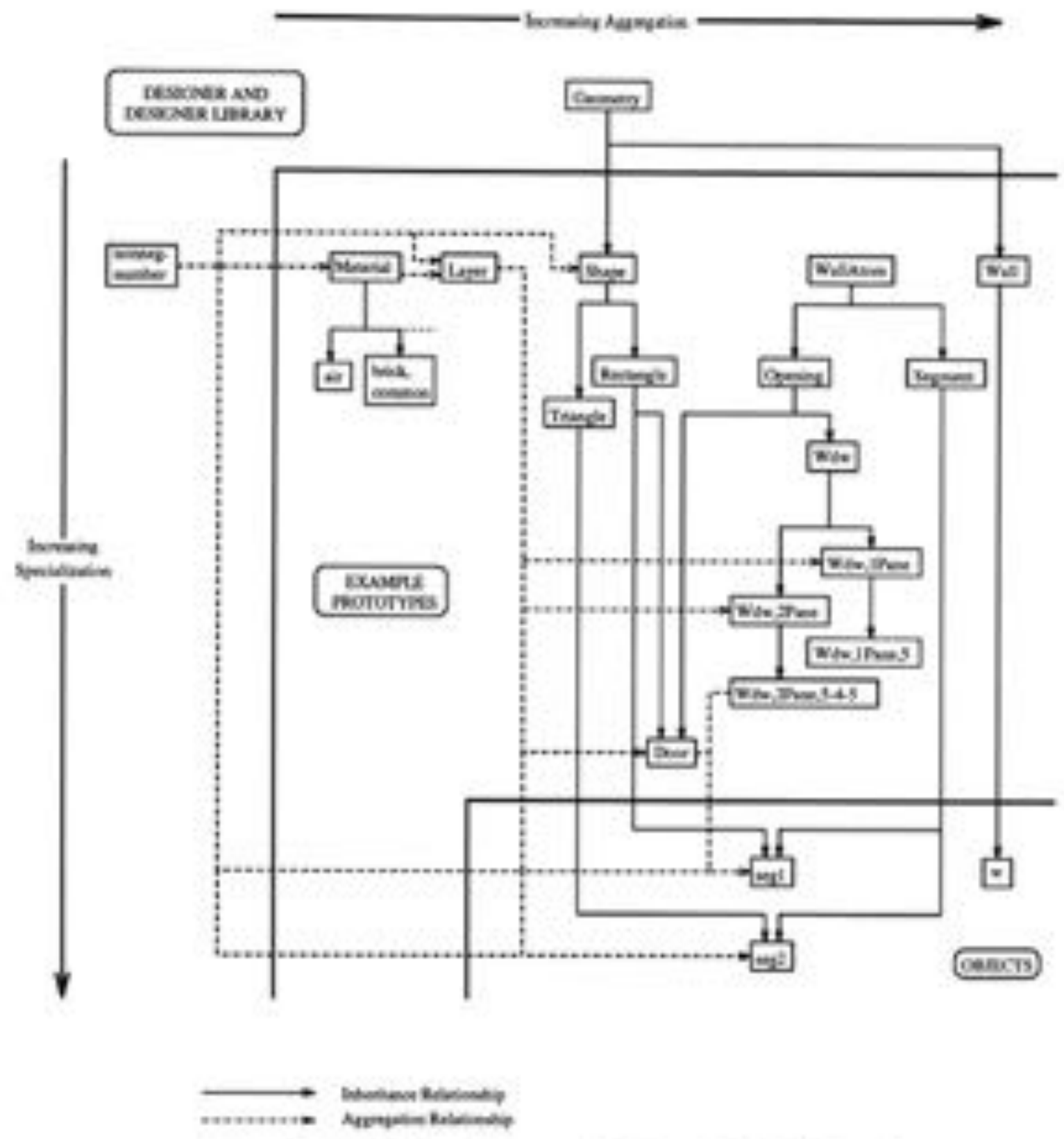

Figure 15.13: InteritancelAggregaion Network for Wall Example. 


\subsubsection{Structural Modeling Considerations}

There ane two important aspects that mist be considered to genenate a useful model of a wall: its foometry asd its corropoition.

The wifth and height of a wall are important in defiaing its relationship to ether stuctural elements, but ae not essertially tipd to its coenposition". The coesiriets en wall widh and height exise at the level of ascinblages of maty walls and thes are beyond cur sitgle-wall model; 20 , froen the point of view of this enample, Beight and width are artitranily defined valuck.

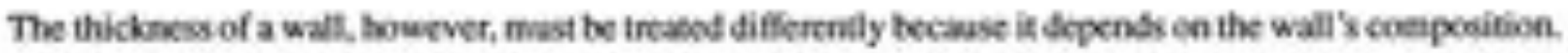
A wall is composed of varlous layers, cach serving a specific purpose - load bxaring, insulation, covering. and so on. Each layer is constrained acoending to the requiftmenes of that particular wall, which in tum coestrains the wall's overall tackness. So though the heighs and widh of a wall are artitrary (from the point of view of the wall model), its thickness is not.

Therefore, we will represent height and widh as parely goometric exiendional arsibutes and thickness as an intentional attribute depending on the walr's composition.

\subsubsection{Thermal Analysiks Modeling Considerations}

For the thermal analysis potice of this erample, we will make use of the following physical nelaticeships (dran from [97] and a standand themodynimics text 1214]

The heat fow theogh a wall is megesented appocoinasely by:

$$
\varphi=\frac{k A}{t} \Delta T
$$

where $\Delta T$ is the change in iemperature through the wall froes the warmer side bo the cooler side, $t$ and $A$ are the thickness and arta of the wall respectively, and $k$ is the themal conductivity of the wall.

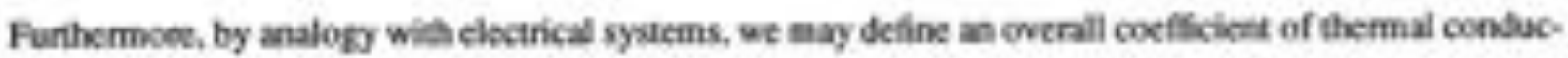

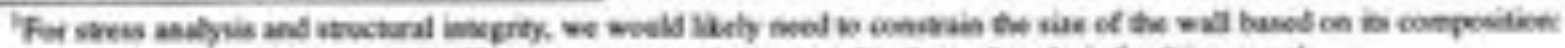

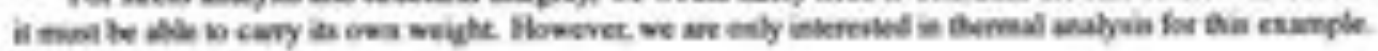


tivity, $U$, for a wall of many layen of ponsane area as:

$$
U=\frac{1}{\sum_{d} r_{1}}
$$

where $f_{y}$ is the themal resistance of the ith layer of the wall. defined by:

$$
r_{i}=\frac{t_{i}}{k_{i}}
$$

\subsubsection{Definition of Wall Prototype Objects}

We begin by definine a prosotype for simple planar gocmetric Shapo objocts (Figure 15.14), with atritules of height and width. Shape objocts will te usol to define the major componenes of walls. The arta of these shapes will be of importance in the themal analysis, so we include the definition of

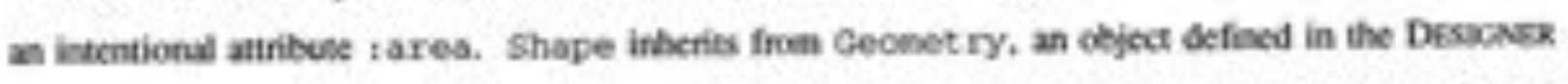
prototype libary which mosels an artitrary spotias objoct. peoviding a local cocolinate frame for the object and messages to perfoem various trandoenations.

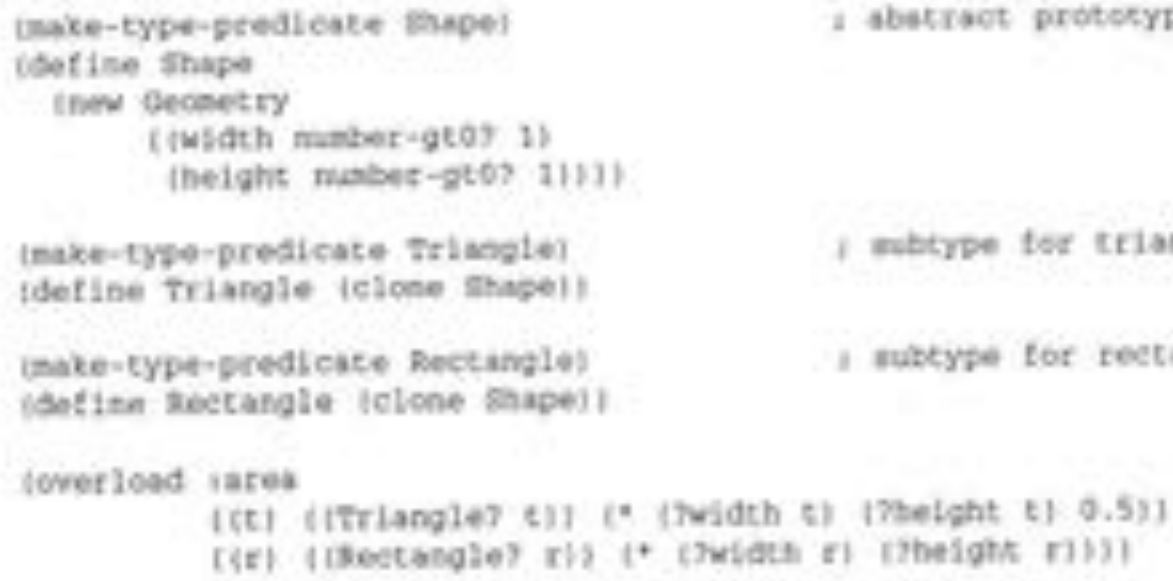

Figare 15.14: 2D Shage objects.

Nest, we need to represent the notion of a laytr of a wall. We shall assune that a single layer is conposod of a single material and is of corctant thidness. Layer objects are defined in Figure 15.15. For the 
sake of the themal analysis, we inclade a mossage defnition for sthern-resiat, which retums the thermal nesiutacec of a layer of a givets tickness and nabcrial.

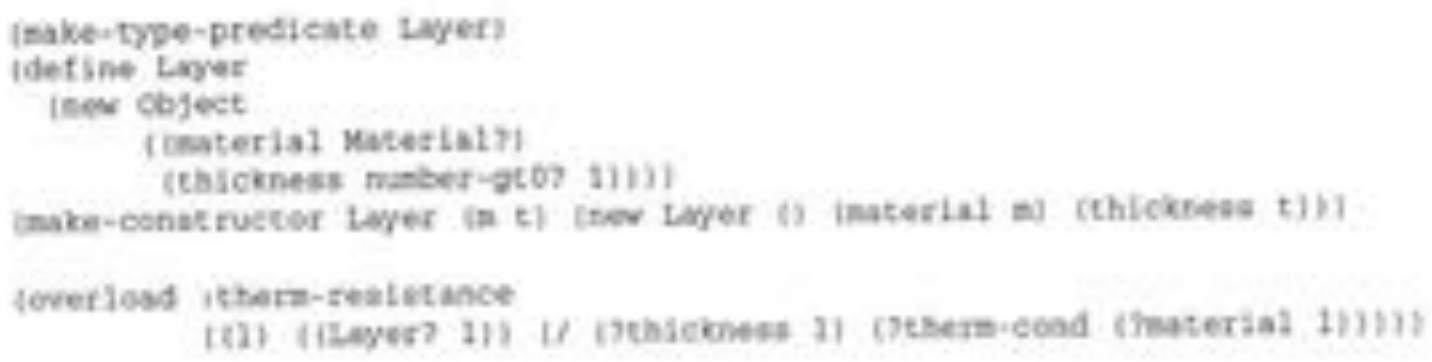

Figure 15.15: Layer chints.

The Material peoctype is defined in Figure 15.16; for brevity, we have inchaded cnly ene necessary property, thenal confuctiviny, and the few insasces aceded for this exanple. Thermal cendactivity data was taken from [214). Numeric values are in $\$ 1$ unitc.

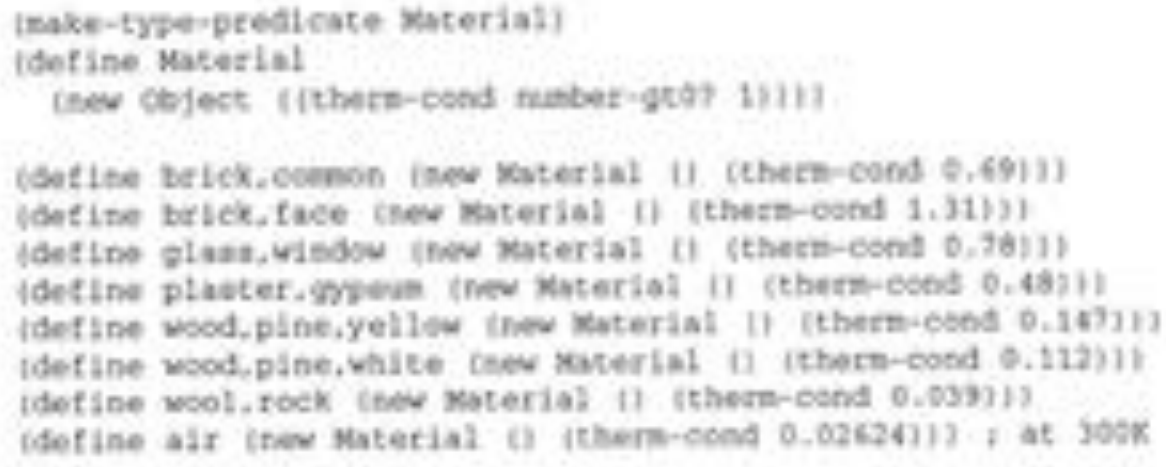

Figure 15.16: Macrial Probotype and lnsances.

In ceskr to permit the creation of walls with moce coenplex genenetries than those describod by shape objects, we define a seghired vo be an area-wise component of a wall. Segments will be defined with Shape and Layer objocts. We will also be able to use segnents to define walls that have regions composed of differem layers. However, heicee we define a prototype to expesene wall segments, we must coredider one other compositional element of walle operainge. An ogening is intendod to generaline the notion of passages throegh a wall. For this exarplt. we will only consider boors and windows. An opening extibits the same popenties as segmeris: they occupy a certain aeca, and are composol 
of possibly nany layen (e.g. malti-panod withowx). Since it is desirable to minimize the information concen of our model, we will begin by definine a wa 1 Lat on object that will capeure those propenies common to both wall ogenings and segraents (soe Figue 15,17). It is notod that none of these poototypes. will use the Shape pecotype defined above fer planar shapes. Wa l. 1.Aeces and its descendants aec used vo capture infomation specific so walls other than their shape, We will, however, make use of the shape probotyre laver.

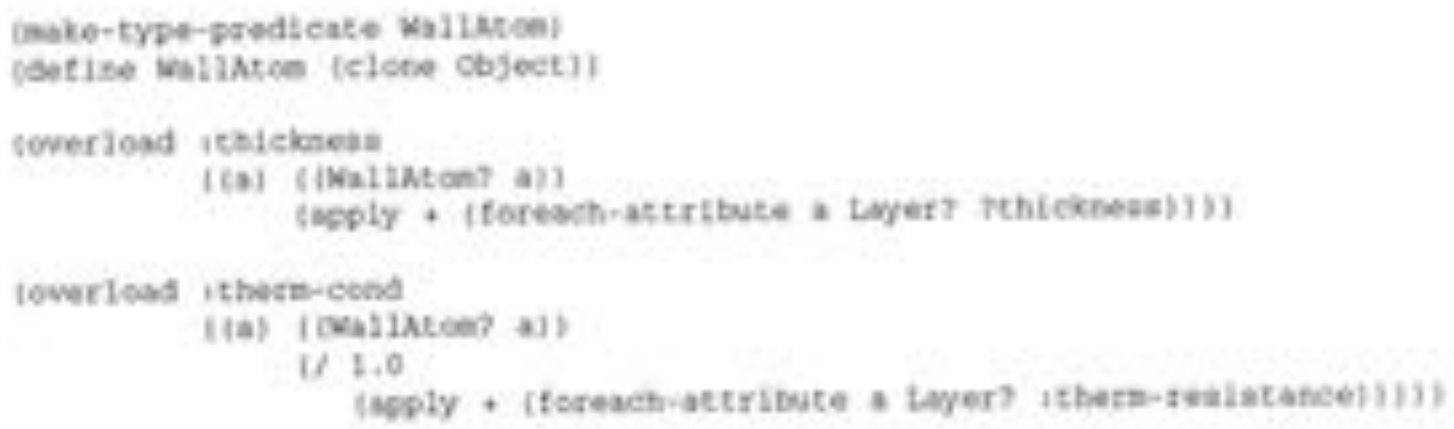

Figure 15.17: Alomic wall componens foe cpenings and segments.

The it hers-coed mescage caloulates the overall coefficient of thermal conductivity of a ka 1 Laken acconding to the mathematical model in Soction 15.5.2. The inatances of foreach-ateribute

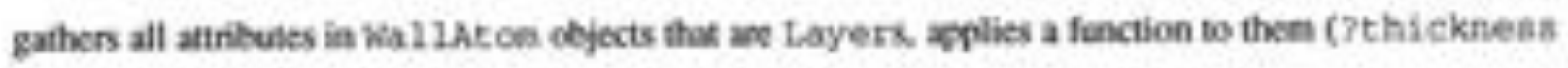
and t therm-resist ance respectively), and neturns the lis esotainitg the results of the function applications.

Now we can wse Wa 11 atcen vodefine poototypes for wall eperings and segments. The oel y real distinction between openings and segacnts is that segnents may conkain operings, but ofenings camos conain other openings (i.e, a window canos have anceler winbow as a compoent?

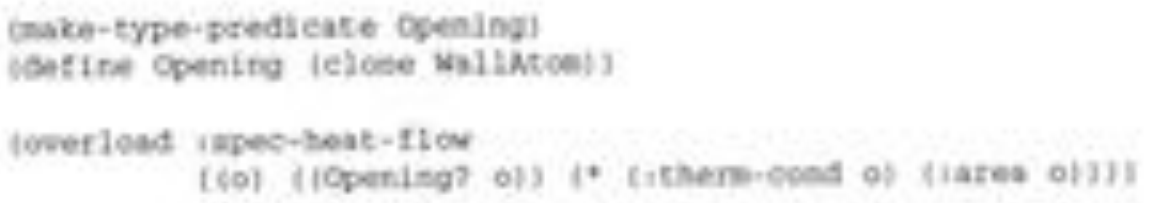

Figute 15.18: Phototype for wall operings.

Frst, we deline an cpening cbject in Figure 15.18. The ipecife heat flow of an opening is de- 
fined as the rate of heat flow per degree of temperature, and is represented by the irbentional aftrituite

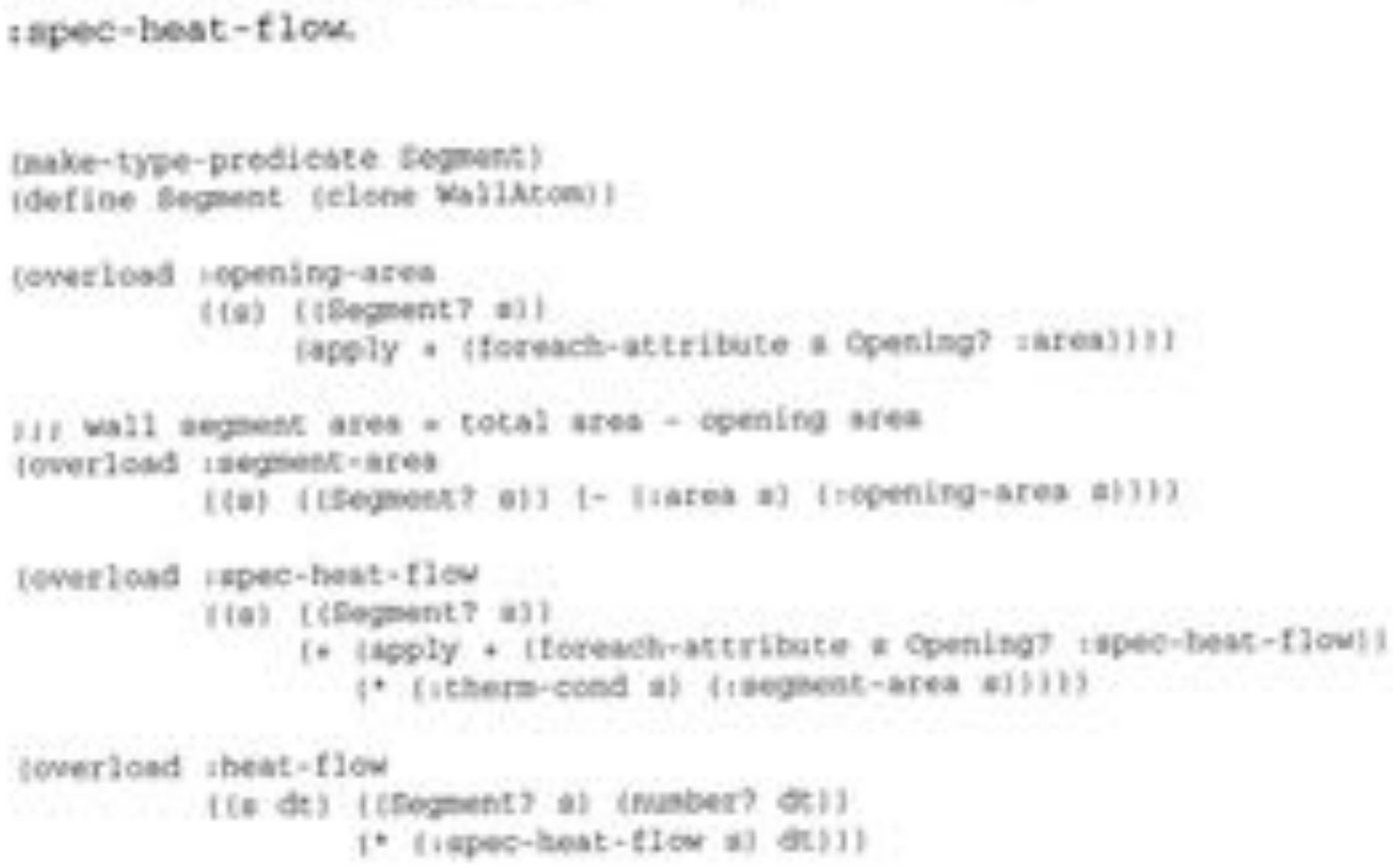

Figure 15.19. Probotype for wall segments.

Scoond, we define a Segnent objoct in Figute 15,19. In this case, we differentiae betwen the total anea od the wall segmene, the area of all the openings (nepesented by the intentional atribate 1 cpenisg-area) and the afea of actual wall material cropresenked by the anribule : segrent-brea). The specific heat flow (: spec-heat-flow) ef a segment is the sum of the specific heat lows of each opening and the spocific beat tow of the rest of the wall. We frally define the atribute theat- $f 1$ ou bo calculase the actual hea fow trough a given Beganent for a given seaperaure diffenence.

Nest, we suall specialize opening foe both doors and windows. Fins, we define Doos in Figure 15.20. Door intherits maltiply from both opening axd seet angle: the former provises those agpects that mprevent devign iment and function (at least. involar as themal analysis is oceccmod) as well as composition, whereas the laner powises those aspects repesencing its other geometric characteristics. The gDoor consruate (creach by make-const ructor) simplifies the creation of single-layered doos. If some particular door has more than one layer (unlikely twough thas might be). it can be created using new.

Varhous protolypes are creanod foe diffenert kinds of winfows in Figure 15.21. 


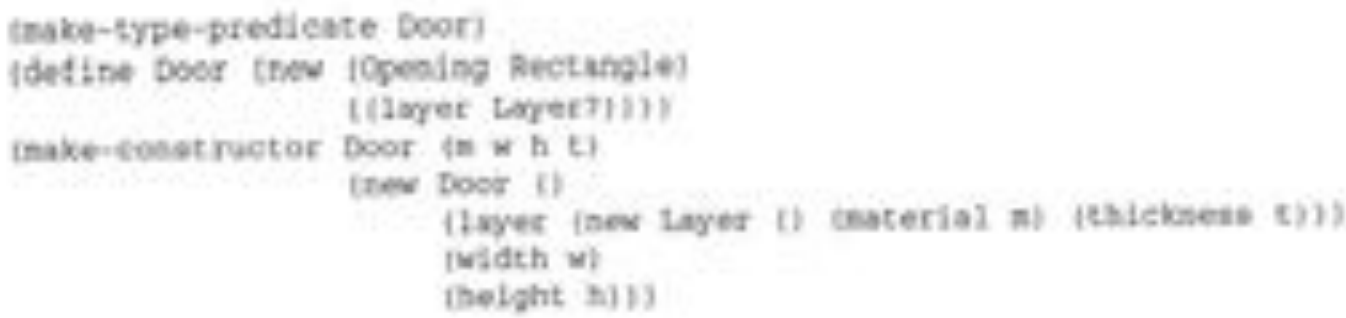

Figure 15.20: Prowetype object for doors.

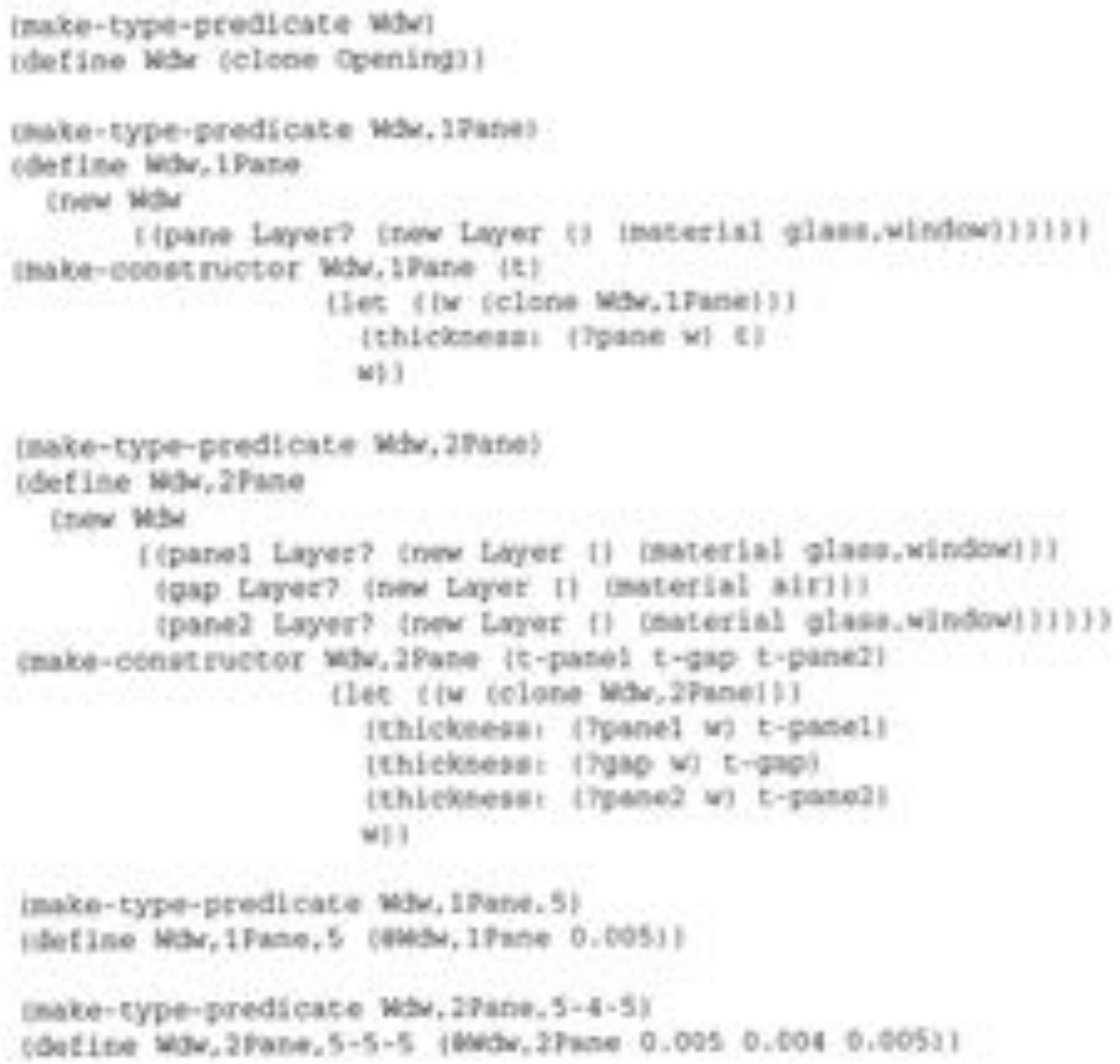

Figue 15.21: Probotype objects for winsoes. 
We begin by defining a simple was objoct. specialized foon cpening. Whts is then specialized into single paned (cadw, 1 Pane) and double-pased (Mdu, 2Pane) types. In both caves, glass is wed as the material for the pones, and in the case of How, 2frane, the inerstitial spoce consins alr Constructors

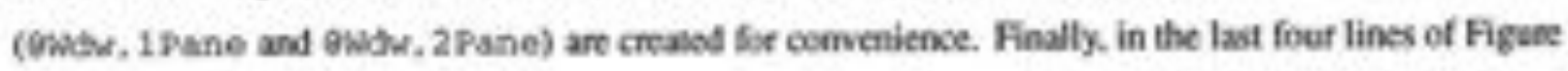
15.21, two specife kinds of windors are crealad: Wdu, 1Pane. 5, a single-puncd window with a 5 millimeter pane of glass; and whe, 2Pane, 5-4-5, a double-poned window with two 5 millimeter panes. and a 4 millimeter air gap between them.

One las proverype needs to be defined: the wall itself. Since all the inportant fanctions for themal analysis have been definod wibin Segnent and Cpening, the Wall object noed not be much mone than an aegregase ssed to gaher wogether valous segment objocts. Wall is defined in Figure 15.22. Our model provides inertional antitules foe the ovenall area of a wall ( 1 area) and the total afea of all openings in a wall (topenits-area). It also provises a message sheat-flow llat calculates the vecal beat flow through a wall for a given iemperature diffesence.

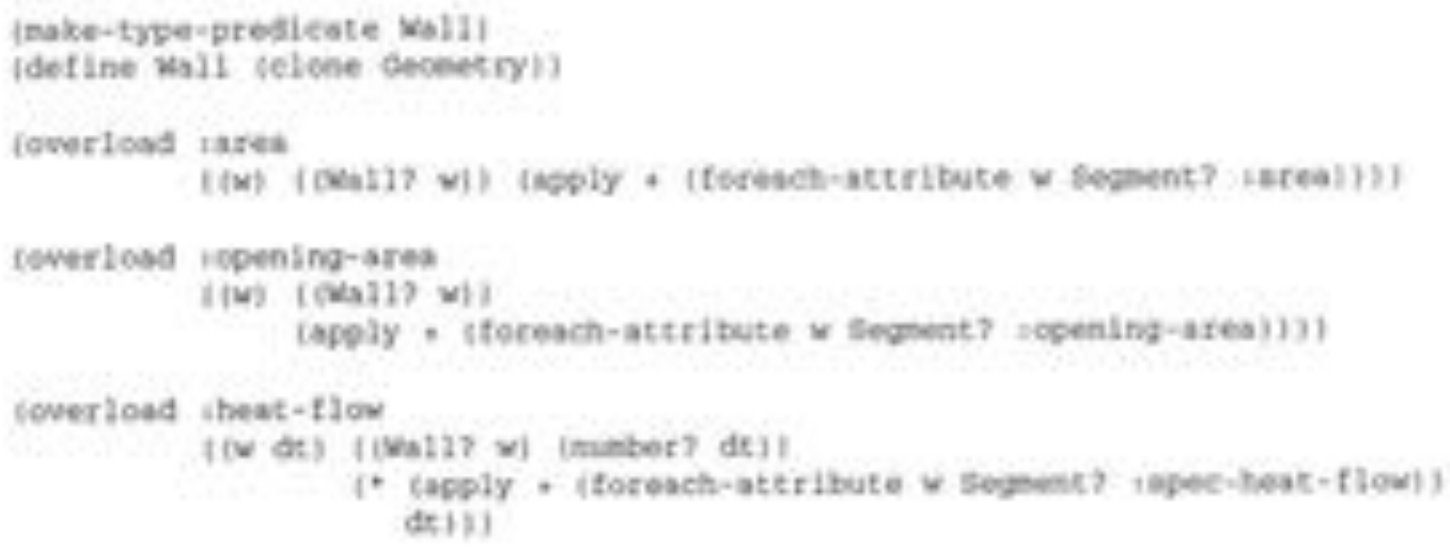

Figere 15.22: Prototype object for walls.

\subsubsection{Example of Wall Model Usage}

We now presere an example of the use of these prosotypes bo define a particular wall, and calculate the heat fow through in. The sample wall will concist of two scgmeats, a large rectangelar segment coetaining a window and a dooc, and a snallict triancular segnen with no openinge. Figuse 15.23 defines these two 
segments, and the wall they compose.

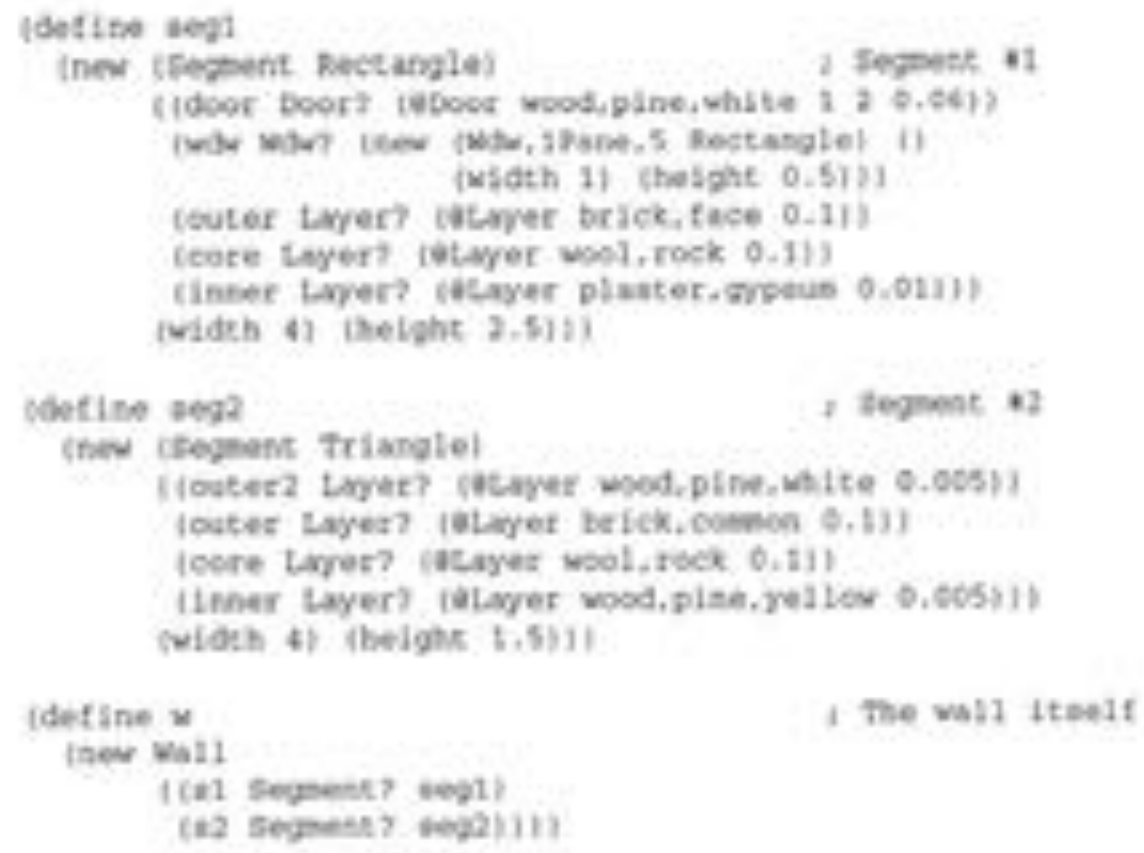

Figare 15.23: Two sapaple wall segments.

The rectangular stgment, aeg1, is composed of three layers: an culer layer of brick, a central layer of rock woel (for insulation), and an inner layer of plactet. The door is made of pine, and the window is singlepaned. The trangular segment, sog2, is coesposed of four layen: an inner pine layes, a central

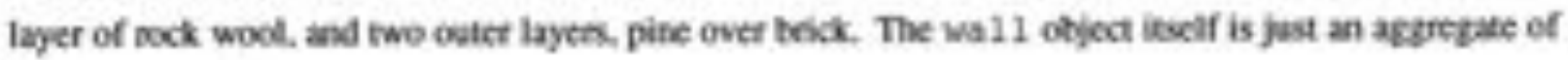
the two segments.

Figure 15.24 shews thete mescages seat to the wall $\mathrm{w}$, and the values petumet: the last query getums the heat Bow though the wall foe a tempenture difference of 20 degrees.

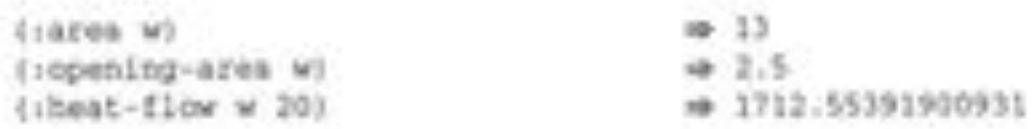

Figure 15.24: Bescages sent to the sample wall.

We can then change the window in wall w to be doutle-paned, to see whe the suring in beas Bow will be. if any. This is shewa in Figure 15.25, We find thax a dosble-paned window can greally imporve the 
everall themal incalation of the wall.

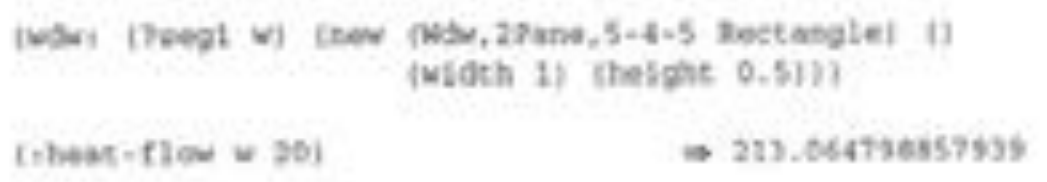

Figure 15.25: Aliering the sample wall.

\subsubsection{Observations}

This exumple denonotrates the conciseness with which relatively complex models can be cread. The eritise wall model as defined is this Section consists of less than 200 lines of code, and some of the modet

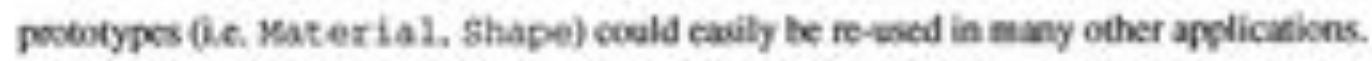

Funthemoec, because design intention is modelied in a relikively straight-forwand manner, we conclube that analysis of design ereity models created with Desockex can acouracly refloct on the adogescy of ose concoptual moscls of those entities. Foe esample, beth segments of the wall creaned in Figure I5.23 inherit aultiply from Segneet and from descendans of Shape (i.e. Rectangle and Triarigle). If is at this point that the geometric and compositional aspects of the model are combined. These aspects are. inoofar as we have defined them bere, independent. Their coenbination has been defersed wo the point Where it was absoluiely necessary. We may have combined shape and segment objocts earfier in the develogment of the modet, but this woild have led 60 an increasod number of prototypes $6 . e$. there woult have been potokypes for noctangular openings, noctangular segments, ariangular openings, and triangular segments). This approch would have introduced a great deal of redendant information that would hove mafe our model more difficulat 10 coesprehend. As well, the subsequent addition of other kinds of shape ofjects (e.f. Circle) would have requirted ext aldision of circular epering and segment protosypes to mainain consigency with the res of the model. But as we have done it here, we would celly noed to define the Cirele poctotype and use it in the creation of various wall segments as requifed. Thus, an analysis of the coeapunational nodel of a wall in DessoNEx comegoonds so an analysis of the conceptual model underlying the computational one. Sach analysis can improve cur colleative ahility to perfom design. 


\section{Chapter 16}

\section{Discussion}

Desionex, represents a new coetpetarional paradign for englocering applications cembiring the advantages of functional and ebject-oricnated poogramaing paraligns in a seanless and usable system. The functional parafigm less us use nobut fomalisms that ensure logical ripor of the mestlieg spaem, while object-oneneation gives us the ability to model eomplex entities and relationahips dinectly. Semartic data modeling powides a unique viewpoint on the noture of atributes.

Desscevex largely sotisfies ICM. Since HM minimines impedance misenunches with recpect to the user's cognitive model of design information by means of its isomorphism (soe Part III. Desicars. alwo mink. mikes impedance mismatches with mopect to the wer's cogritive model.

Desscine is not incendod to manipulate data, satisfy constrints, perfoca analysis of design models. or database management. It is a static data modeling langage. However, because of Scheme's meta.

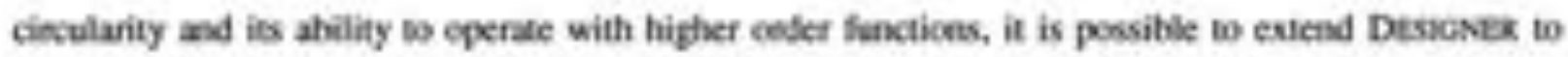
include fynanic data modeling capabilities fie. the capahility to operate on and ctherwive manipulate data as osposed to its specificationj.

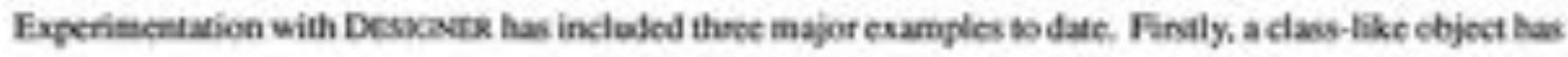
been successfully implentented using Drsocsos's bow-level probosping facilities, This implementation captares all the busic poopertics of object claves as they are exnventionally defined in languages suct as SUuLtaLX-80. This indicates that our computational model is as espressive as models usod by 
corventional object-orienad languages, yet simpler and moer general than those models.

The second example is the four bar linkage modet. This example demonstrates Desicener' 'S atelity 10 eapoure quite arbitrary \&esign information. and tha it is noe restricted to modeling the dedign artifact alone, but can include the artifact's functional specifications and design intent (e.g. the relationchips betwecn

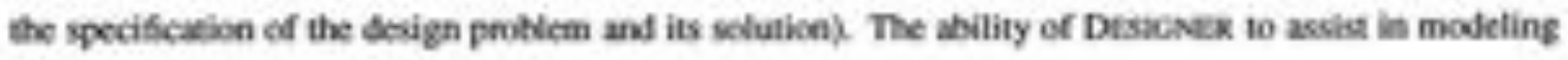
design artifacts in the concoptual stages of a design process ate also indicanct.

Third, the cxample of structural and themal modeling of walts demonstrates the atelisies of Dessower and its underlying formal models to capoure detailed iechnical infomabon as well as moer gcneral conceptad information about desiges. Also, the comespodence between Desocede congutational models and users" conceptual models facilitates the analysis of designs in general.

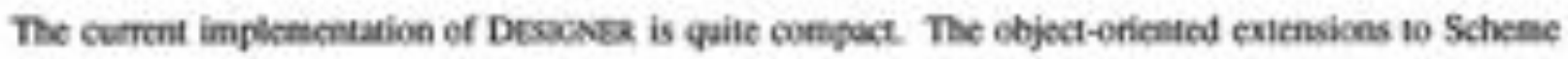
that form the core of DEsaceer amount to about 300 liscs of code. The Desikunes probotype Iitrary is only about 700 lines of code and includes circular lists, queves and stacks, complex nambers, 3D points and vectocs, Mretogencous 3D trasformatice mathces, coondinate frames, and some simple panmetric solid priaitives. Desncastk currently has no graphics capukilities, but even 90 , the auther feels it is a snong demenstration of the ceeciseness that can be achieved using object-oricated coexpes in a formal fanctional framework.

Dessones curnently satisfics all the axioms of HM but fwo views and peneralization. Dessones docs pennit the creation of sub-objects (subsets) but does not captare the view relationship between an object and its sub-objocts explicilly, Views art diffcult to deal with becase objoct coretraints introduce coupling between attributes in an objoct. At this time. it appears that each object constraint implicitly defines a vicw unceuplod from ether views however, it is not clear that providing seppert cely foe such uncoupled views is sufficiere. Sultable theory will have to be penerabod reganding the interactice betwoen ofject constraines and views before the latier can be supported fally by Dessevex. We noee here that Deskavex has fulfilled its ocle as a vestbed fee HM by providing ws with this insight regasding its adequacy as a model of design information; however, it does not afloct the logical validity of HM., which is preservod.

Generalization (the inverse of specialization) can sinsplify (momalize) a hieracthy of objects. This simplifeation can bring 10 light relasondhips between objects - and bence between the design entities they model = that may have been obecund by the complexity of the initial hicrachy. Nonaslixation 
can also improve the efficiency of cperaisons on the seftware model. However, thene do exist seme argaments [28,93] that stonely suegest neenalizasion is of liminod usefulness in engincering softwatt systems. These arguments are bosed on the observation that nomalization requires a stable schema (organizatice) of information so cestee comectly, But schena definitions in decien tead bo exhibit a hiphly dynamic nature nomalizing a dynamic schema leads to unprodictable and possibly divastrous mestts. Additiceally, generalirxico implies some faifly complex computation and centainly mone so than specialiration. For these reasoes, the auhce has elected to defer asdition of generalizabion in Desickex. bo future work.

One final aspect of HM that is not directly supported by the current version of Desickex is that of dimeribons of meauremerk, as defined is Section 9.5. Very little work has been done to supgort

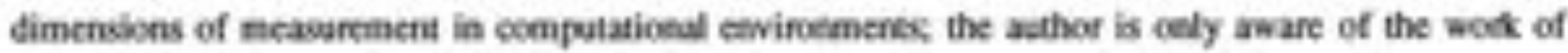
Cunis [217]. Bocause of tho lack of asailable information on the treatnent of distensices of measareacat in computational emironsicnts upon which to build this capability inso Desscosia, the author bas elected to defer the matier to futare work.

The distinction between estensional antibutes and intentional anibuites pernits the capture of various kinds of melationalips (ie. condraires) betwoen anributes is a straigle-forwant marexer, as well, this appeoch is integratiod seamiksty into the functional paradign, thus grtally simplifying the overall computationd model. However, this does indicate a further nelationship between the modeling of attributes and of coestraints. Constrains selate crities at a given degre of abstration, but legic dictates that the constraints thenselves msat exist at a hipher sczree of abstraction. This esserkially defines a nale, or criterion. that govems the formation of conctraint hierastibs. As was discussed in Soction 14.7. the modeling of antributes as inbentional er exiensional depends on the requirements of the design model: this, in tum, will affect the constrinin hienarchy of the model. More rescach is needed in the area of attribute modeling in order to define the relationstip between antributes and coestnins more clearly.

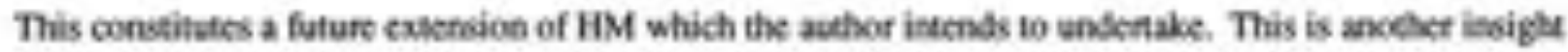
poovided by Desicaser reganding HMt.

Desceosx enploys a caronical message pasing anchanien. Theugh unocnventional, the muthor censibers thete to the a vignifieant afvantage to this approacts the clean separation between ferction (asing gencric functions) and strocture (usine objocts) provides a sinple, inasitive computational model for 
simulation of deilgn antifacts and systems. Furthermoer, the notion of seV, and all the complications thot arise from it, are avobled entirely. Altwough the evaluation of generic functons in the current inplementafion of Dessosex is not perticularly efficient, soveral techriques exist that can significantly imperve its perilomance.

In a multi-user eminonment sach as a design group generic functions offer another potential advanage. Individual grosp menbers may locally overiosd particular fuactions foecause, for exanple. they are so chen wacd by the group member) without affecting the objocts and eder dua seructues to which other group members wodld lave acoess. Tis would sigrificantly decrease the chasces of accidenal data comupticn,

Finally, the distinct sepursion of functions that act on objects (i.e. methods in dassical ebject modelv) from the objocts bemselves pernits the bendling vogether of youps of functions into modules providing a coanoer fom of functiondity. These modules can be looded aubomatically as required. and aubomatically freed when they are no longer nocold, without affecting the data defining the design models themselves. Foe example, a single design model could be used in fwo different tasks (ce.e solid modeling and numerical analysis) by simply loaling modules of generic functions that poovide the functionality notdod for each task (e.e- color graphical mendering for solisd modeling, venus astomass mesh generation for numerical analysis).

Even though inheritance is generally wiod in class-bued sysems, the auther has found in we be be uble in a prototype-based syatem like Dessoker, where, in conjunction with cleaine, it has replaced both subclassing and class insantiation. Furthermoce, the use of canonlcal messapo-pascing eliminales the seed for the user to be aware of occurrences of inheritance, and raher treat the velationhip as the mose intuitive nosion of specialization.

DEscaer permits multiple inheritance cely froen pasett objacts that lave sets of anributes dinjoint from one another. Altwough this restriction dces not exid in ober object-onicriod languages. the acthor is conctrained to impose it becase of the valifiry requirctacnts of HM. Althowgh the goal of mainkaining validiny is a desirable one, we nust also ack oursclves if twis kind of multiple intheritance is enoegh to sabity the peneral noquirements of englncering dedign. There is no simple atswer to this question yet: indoed, there is sotre evidence to sugest that multiple inheritance per se is not noedod at all, and that the ahuractions it porides ea te suplied by single inheritance combined with various forms of 
asgregation [218]. In the mextime, the author conjectures that multiple inheritance of the kind defined by IM and supported by Destowex is sufficien. This is based on the grounds then a coumerexcaple has yet to be found. Ooviously, this issue requires funher study.

The formal desotational seminties of Dessonek has yes to be defined. However. Scheme itself is a foenalined computer language with a corrplete denocational semantics [183, 184]. Denceaticnal semantics

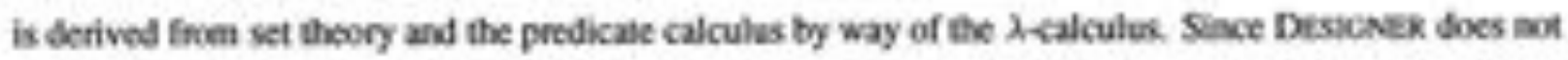
aher Scheme but only estends it within its own formal framewod, there is a coetinuity of logical rigot frotn the fomal domain model (HM) through to the actual implementatice of Desicser. Nonetheless. formalizing Desicsers's extensions is a worthuthile goal to pursue in onder to (a) further conveorate the valitity of HM, (b) ideneify areas whene the implemencaion of Deskiver may be impoovad, (c) provide formal proof that Desicask in fact satisfes HM (from the point of view of computer science) and (d) provide formal bools to atalyoe devign models generated with Desicaer.

There exist other various fonmal senantics (eg. 1208.219) that \&dine objocts in functional programming envinoments. Some aspoets of these efforts ate similar wo the approuches taken with Desicaver. The auther is therefore confident thas a formal semantics for Dessenex is possible without changes to Scheme's essential structure.

Alhough the esperience with Scheme has inficad so the aubor that it is a very useful language for sach

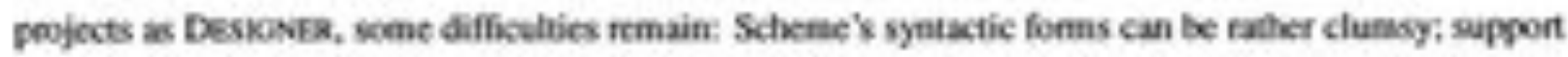
is lacking for centain useful mathematical coestructs (auch as matrices), tee language inself is not tuned oo compote efficiently given the important mechaniams Desacesk noquires (i.e. generie tanctiots and cbject encapoulation), Recent alvances in proyanming language deslgn, however, indicate that these pooblems may be solved adequately in the near sem.

There are mary obler directions in which Desscasen can expand in the funure. We menkion some of them hero to indicate the potential loe growth.

An argunteat has been made in [181] that functional prognamming can permit various degrees of parallelien in compuraben, and that fue to the nature of engineering oomputing only centain kinds of ocurse-grained parailelism can be expected to enhance perfomance. Elininatios of side-effects and strict explicit control of program state vastly sinplify parallelization of coepulabion. Objocts providing strict encapoulation of insoenasion, as in Descoes, mees this nequirement and may provide the mears by which granalarity of 
parallelitun cas be male more coarse. The inclusion of an objat system in a functional language may luss be an ibcal solutice. Altheuph Desockes boes not currently suppost azy parallelism, the author intends to investigate this possibility in the futare.

Asother area where Desicaser may find applicabon is iasysem sienulation. Advanced computer modeling and simulation of prodacts has beta Eaining popularity [220] because of its potential wo save a significant amount of time by eliminating the need for physical poototypes. The fenctional paralign pernits the straigh-forwas developenent of quite complex procedaral units. Furctions to measufe time and generate signals ase included in many impienentations of Scheme. Detallod models of conponents and design artifacts are also possible in Desicsex, owing io the objoct-ersented mechanisms in cmbodies. Thus, system simulatioe is also possible witbis ahe same compuswosaf modef as are other kinds of engineering computing.

Since Scheme can be usod for symbolic manigulation, a sysicm to symbelically manipelane mathematical espressioes eculd be ietegrated wils Desscosa to peovide extensive mathematical support of varioes. kinds of andysis and synthesis in a scamless and integraod way. For exattple, algetraic functions can be everlouded to operate on symbolic espressions (in Scherne - and bence in Dessaver as well - syabols sach as " $x$ " are acceptable data valoes that may be eperabed onl. Funthomone, functiots that manipolate symbolic represcntations of equations may be overhoaded io powide mumerical appocoimations if mameric

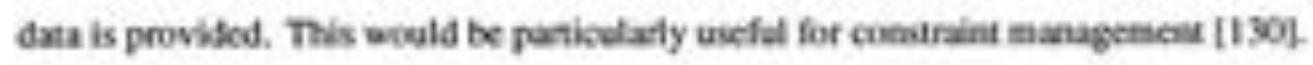

The culminction of the reseach eflort that the asther has sartod and deveribed hertin will be a new computer language and associaned computational model specifically gearod bo enghocring design. The language and compatational taodel would satidf HM and be formally defined using denotational for some othen) semankics. This language will provide a conputing emvimoment for enpinceting that will be esable not caly for cotwemicnal engineering computation, but alw as a vehicle for the continued formal stady of engineering ocsign.

We noee that this appooch is itself a strictly formal apposch. It makes uve of esisting, proven tools of coatipuer science and bgic, rather thin the more hap hagand means by which many languages currently in use in cngincering emironments wete developed. 


\section{Part V}

\section{CONCLUSION}




\section{Chapter 17}

\section{Final Discussion}

The consribution of this thesis has been toesplain the natune of engineering design infomation in objoctive, formal tems.

The formalixation of design information must be terated independently of design processes which affect or otherwise maripulate the indormation. Becase of its independence from desiga posesses, sach a fomalication is univenally applicable to any stape of aspect of design. The author has achicved this goal with the Hybrid Model of design information, introduced in Pant III. It provides isoenorphions that let us view design informatice objoctivelys and its structured notation permits us to rtavon formally about design information. The abotroction mechaniams ineroduced in Copter 10 ane foundod on ontologic considerations of design. They permit various efganirational schemes to be developed, maximizing the anount of available explicit informations this in tum minimizes the amount of isterpresanian noquinod. thus increasing confidence in the cutcone of actions bued on that infomasion. Furthermoec, by slhering to the rules feganding the exuension of classical set theory, HM is proved valid with respect to its logical foundatioe (set theory); that is, HM is no less valid than is ZF. HM can facilitate consinued reseanch into design by providing a universal fomal languxe for the specifoation of desien information. Its uve can imgrove qummenications betwoen desigers, ontribute to the developenent of efloctive new tasonomies of design entities and processes, and kad to the creation of mone powerful compuierined designers" aides. The use of formal systems greatly clarifies our undersanding of design information by helping to rewive diffculties ariving from inoomplete and vatuely definod ncencnclaturt, maraging the changes resulting 
from an evolving netion of desigh, and elinininating sources of logical inconsistencies such as self. reference. Insights of bogie have lead the auther so inenoduce conceptual boots - the layered stricture of design (Scction 6.1), and the notions of a drsign space (Section 6.2) and artificial science (Soction 5.2) - to help erganine our collective design and design research efforts. The ncults will axist in unifylng otherwise incompatible techrïques and methosologies by powiding a notust and valid reference.

La clearly sepanting the structase of design itself from the manee in which in is conducted (the whar of design, versus the how of it, the athor acknowledges the important role of the designer as the singular atent by which design is manifested. In this scnes, logic is soen as the means by which the designer's

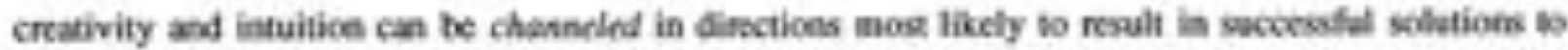
¿csign problems, moch as it has been la cther "scientific" felds, and forcing us to think more clearly by peoviding a system whenein logical errors are moee easaly detoctod without sestricting cur frocdom to cxpoess consiotent. relevart information.

In onder to demondrate the advatage of fomal sysicms in design. HM is applied to the developenent of a new programming language for design (see Part IV). The Dessckes larguage is meant to capeare aftirrary design informaxion in a flexille framework while largely satisfying HM. In so doèg, we provide a bridge beteen design theory os the ene hand and the developenent of practical competacional bools to aid the designer on the other. This coetinaity of formal rigor has not been achieved befoec, and increases eur coenidence is the validity of the language. The unique approaches taben in Desacaver fe.g. Ee use of poototypes raber than classes, and canceical raber than conventiond mescase passing) are necescary io meet the roquineracests of Scsign as a unique and stoceventiond informatice matagement somain. The bevity of iks implementation in Scheme is saggostive of the clarity and elegance posible theough the we of formal thooses to guide the development of engincering softwas. 


\section{Chapter 18}

\section{Future Directions}

Future research finoctions for beth HM and Dessenes ane disoussed in decail at the ends of parts III and IV. Here, the author ontlines is a mort general sense what the fature may hold for the wook presented nerein.

The key relationhip berween HM as a formal systen and devign theory is the isomorphism the author has identified between set theory and design infomation. The advantage of a fomal sycuen with a precise notation is than it lets one see nelatioeshipo between infoenation in a far simpler and objective way than is possible with moe verbose sysiens requiring significan inempetason (e.g. using the English language insead of mathematical logic). Further sudfy of the abioms of HM will ketly bring to light nes relationships between Vinds of engineering informabon, and thes impone our undensanding of desiga en the whole. The discovery of new relationchips asy nocescitane modifications or other extensices to HM: this feoflback will be beneficial to the developenent of both HM and design in pencral. The particular iscues thas will noquire further imestigasion ia the near iem ave aggegations (the peiarary mears by which specific simple design entities are grovped into mone complex entities) and constrints (the driving force behind the desige process).

Besides the isaplementation of progranmine larguages for devign, HM could be appliod os a number of other actas of competer aidod engineering.

The axicenatic form of HM makes it çuite ancenable 60 implementaenon with exiuting logic poognamming 


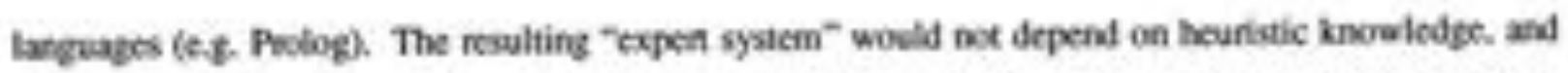
would be wefat as an andysis bod for design models generated usine other compulerinod loots (eg. Desxastx). The use of heuristic knowledge, as has becn indicaled in the literabure survey (Sectice 2) cas markedly redace the confidence level ef expert syslems by captaring "lonowledse" the soundness of which cannot be provol. Sisce the number of axbors in HM is quile small, an expert system implementing it may be able 10 perfom in a timely masner.

Another anca where HM could find use is in the senerasion ef enginoering dasabases. Many operations for ebject-orientod dushuses nay be writen in verms of the axion of sepuration of set theory (193). This inplies a felarionship between dacabue theory and set theory (and henee HM) which appears promisiag. There is a well esuablished poecodent in the Tinerature foe the general usefulness of object-oriented dxabases in engineering $[56,102,106,168,221.222]$.

One imponant difference between programming linguage design and database design is the nobon of

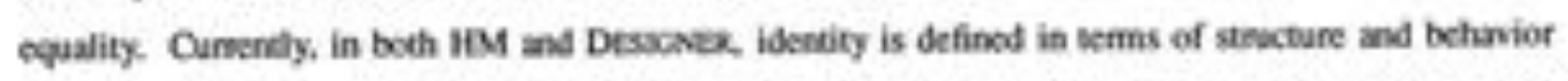
of objects; this means then identical objocts ane perminted so evist. However, in darabuec thecry, such idencical entities are gentrally disallowed $[223-225]$ to makinain the dexbuse in a nomalinod forms in

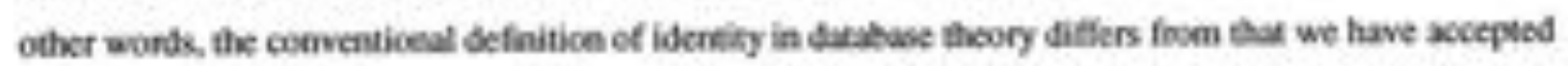
in this work. This discrepuncy will have to be addressed befort HM can be used to generate useful enginoering databases.

Finally, and perhaps most importantly, $\mathrm{HM}$ can be wed wo help seach design in an objective and rigorous marner. It is a relaxively small formal system thes allows prectse definition of terms, and a coesisten systcan foe the erganization and poesentation of information. The actud languape of symbolic logic, as used in Part III of this document, need not be introduced immediately: key notioss ef any theory can be tught by example, as has been done by ethers $[31.36)$. Nowever. the author feels that an introdoction 60 formal systems and symbolic kegic sufficient oo understand HM would not be a lengthy underiaking and would prove a wontrwbile podagogic investacn. 


\section{Chapter 19}

\section{Closing Remarks}

What is engineering design?

This document began with that very qoestion. It is useful now to retum to in and detemine what headway. If any, has teen made wownds answering it. Has the author's work presented in this document anowerd this questice? The arower is io a certain extert, yes.

It ana be argued that be question iscelf is not a particularly good one. It is too vaguc, too open to

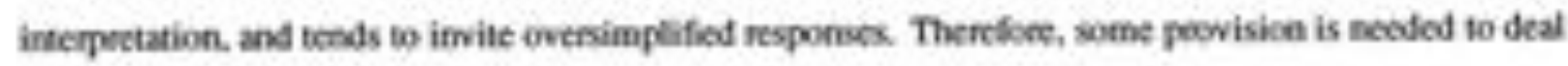
with the inherent ambiguity. In koepitg with the genenl none of this work, the auther regatts the iniension of the çestice "Whar is engiecering design?" as being of a descriptive nature. That is, we do not wish to cenfuse this question with its pocedural complement "How is engineering design performine?"

Many of the paramelers by which designs an judpod ane bused en quantinative measures. This indicates that design is nooted in the physical world. A designer's "attiste" atilities ane coestrained insolar as the results of hils efforts mast comply with de evigencies of the physical world. Furthermece, upen neflection on the argumerits made in this dxcunent, it is clear that any exiemalization of the design process mary be sobjoctod to logical analysis. Derefore, the autor concludes desige wuse be lergely national is namare.

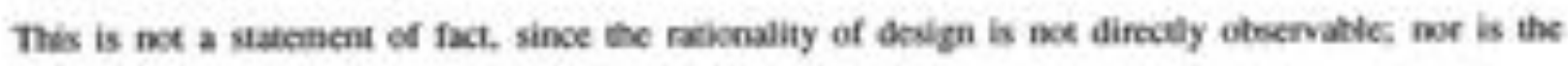
athor's work to te censtruad as a (lecturical) proef of this notion. But die body of evidence herein the arguments made in Pan II. the definition of HM, and its use to create the Dessener programining 
larguage - stronely indicase that design has a defiatie structure that can be treaned fomally, objoctively. and rationally.

We have insertionally said nothing about how devign is perfomact. This issoe incledes the nole of the human designes and is poone to effects (each as self-reference) that sevetely limit the applicability of formal technigues. Nenetheless, soene very impertust beadway hes been made in this wod; heabway that represents a strone first step lowanks a betier undenuading of enginoering design. Although it has tracrsod the spectrum from the thoorotic to the practical, the central theme of this work has been to demonstrate that the use of logic can give es usclat and relevas insights into the nafure of besign. The most importast of all, in the opinion of this author, is that logic has becn found to be sufficient bo explain part of the problem: HM has given es the means of delining the aarure of design information ia fomal and objective tenas. It provides the means of capearing, andyzing and commuricating design infomation effoctively, efficiently and in a timely monnet. It gives us, designers and derign nescanchers, a framewod. to goble oar thinking and eur work, by providing a logical symea no verify cur ideas and thoughts. Upon this foundation ncw theoties of the design process may be beilh, stengthening our undenstanding and improving ove atilitios to moet the challenges of the fuoure. 


\section{Part VI}

\section{APPENDICES}




\section{Appendix A}

\section{Source Listings of Designer}

\section{A.1 Designer Source}

This section lists the source of the Designer language.

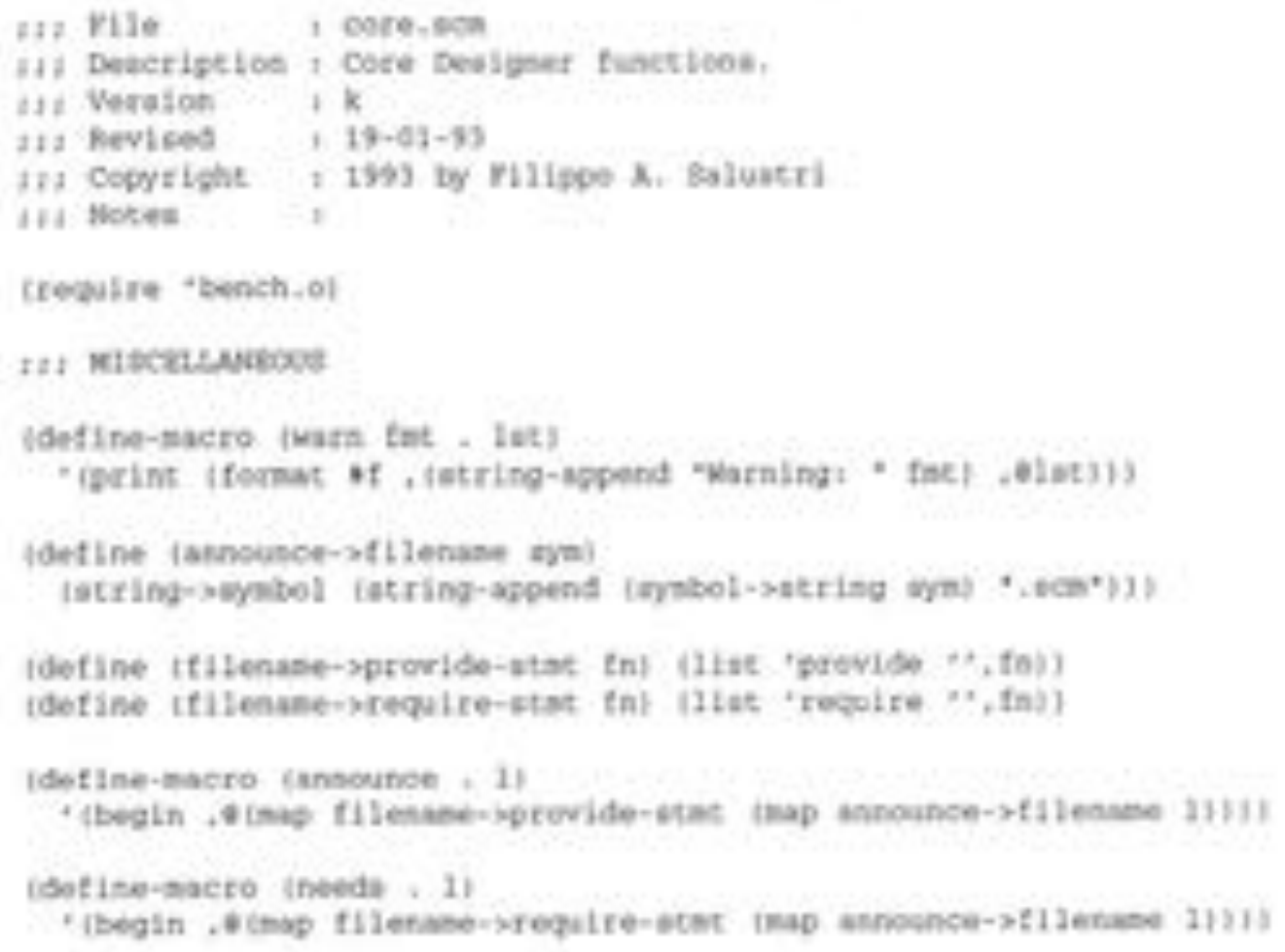




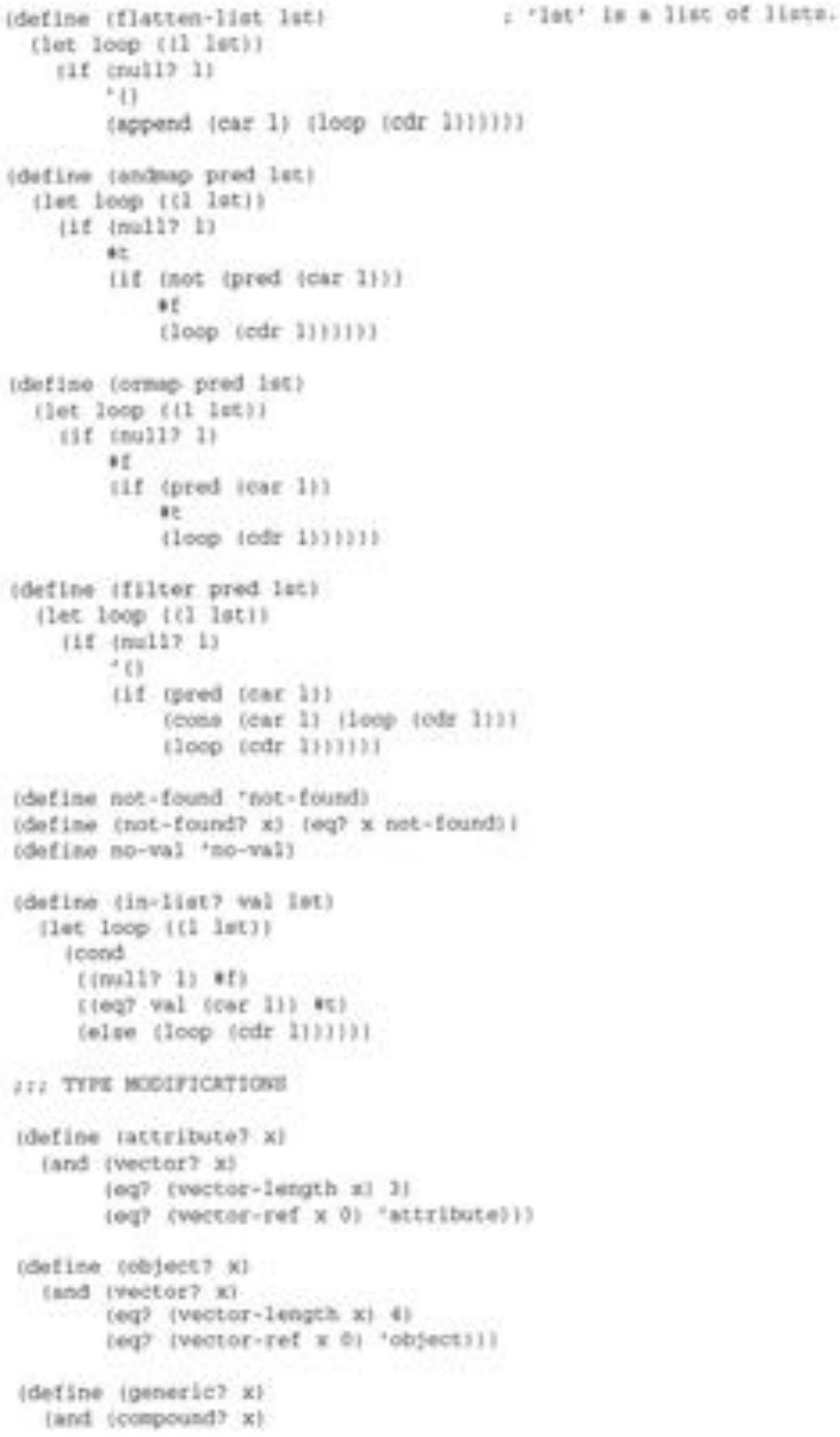




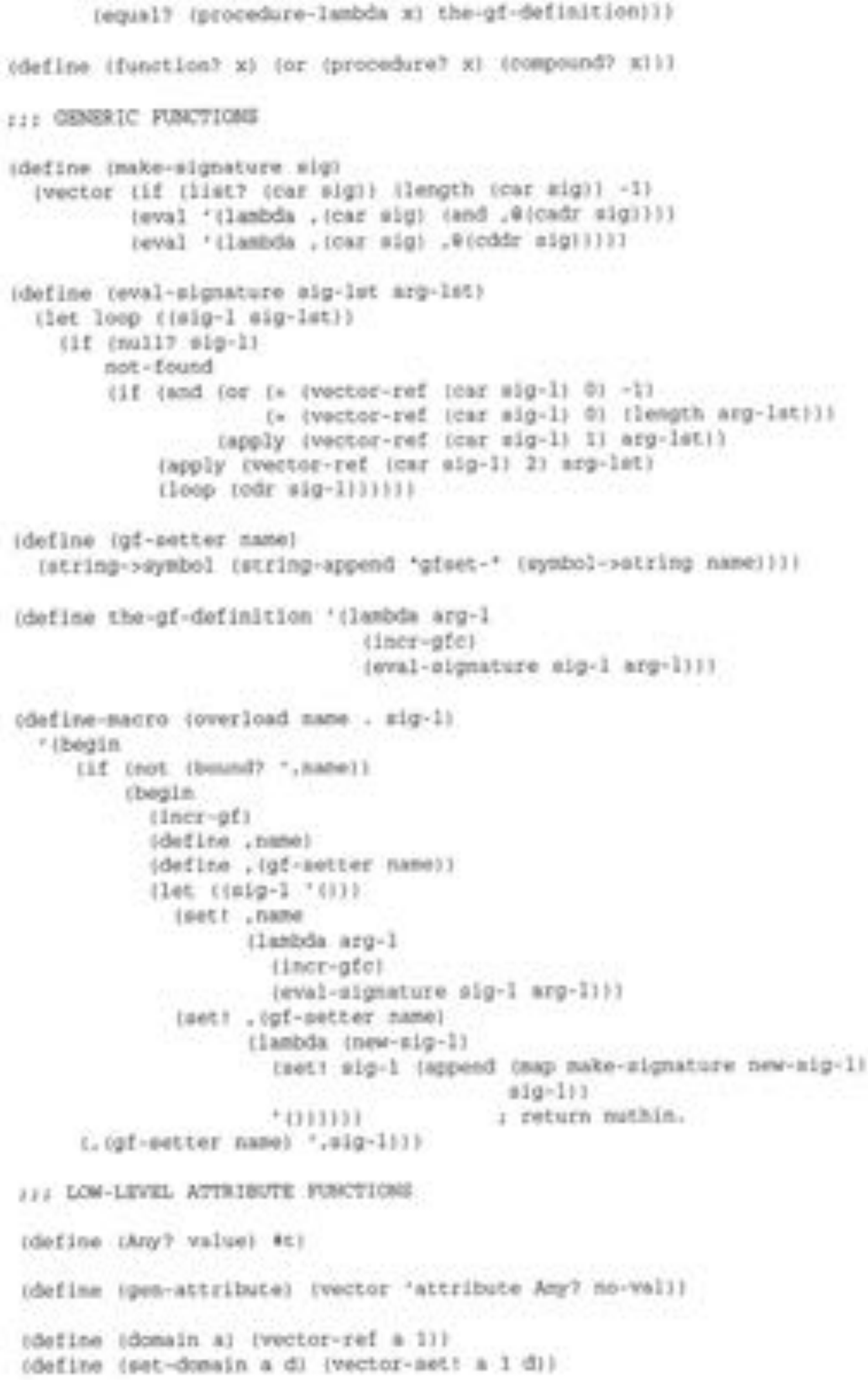




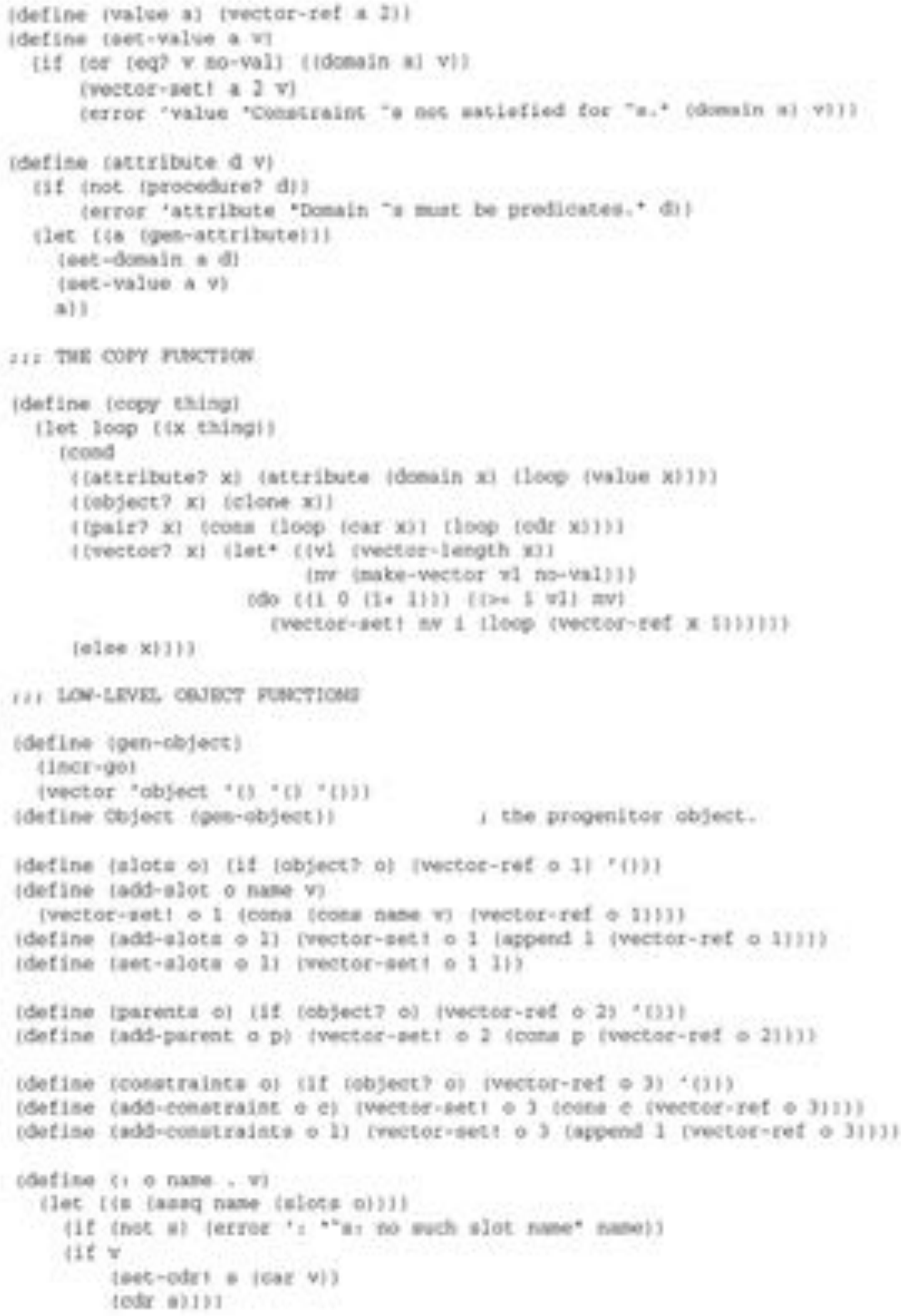




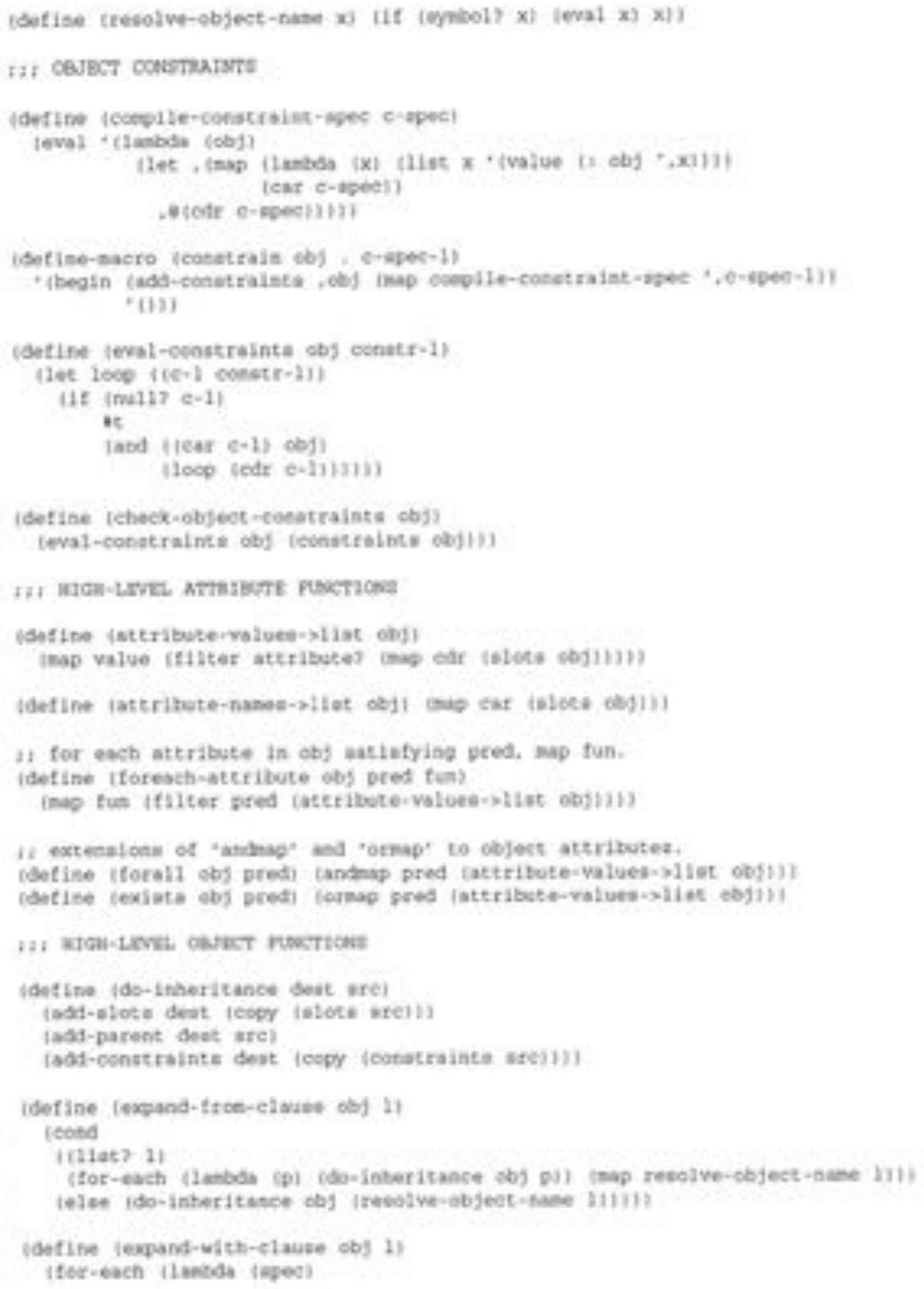




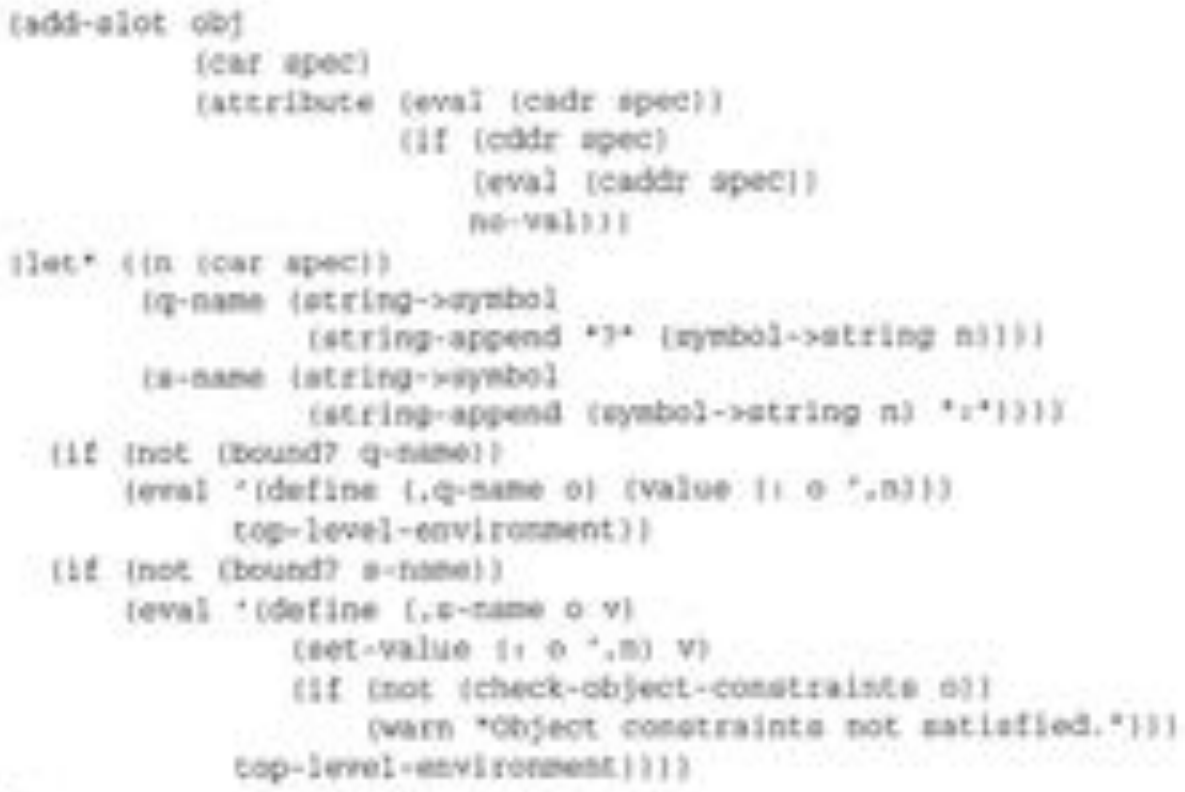


392 idetine-necre imake-type-predscate of

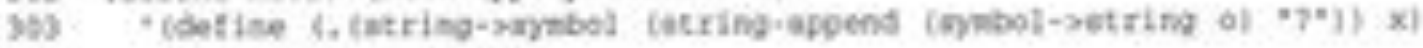

$304 \quad$ (ancester\} $x, 6\} 1\}$

205

305

Idefine-abcro (hake-cotstructor D + rest)

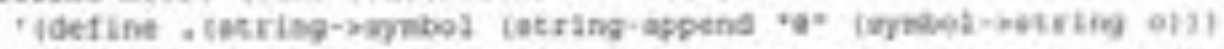
Itastala ,aresti3 


\section{A.2 Support/Utility Funetions}

\section{This soctice lists various functions used extcnsively is Designer. but which are not part of Scheme.}

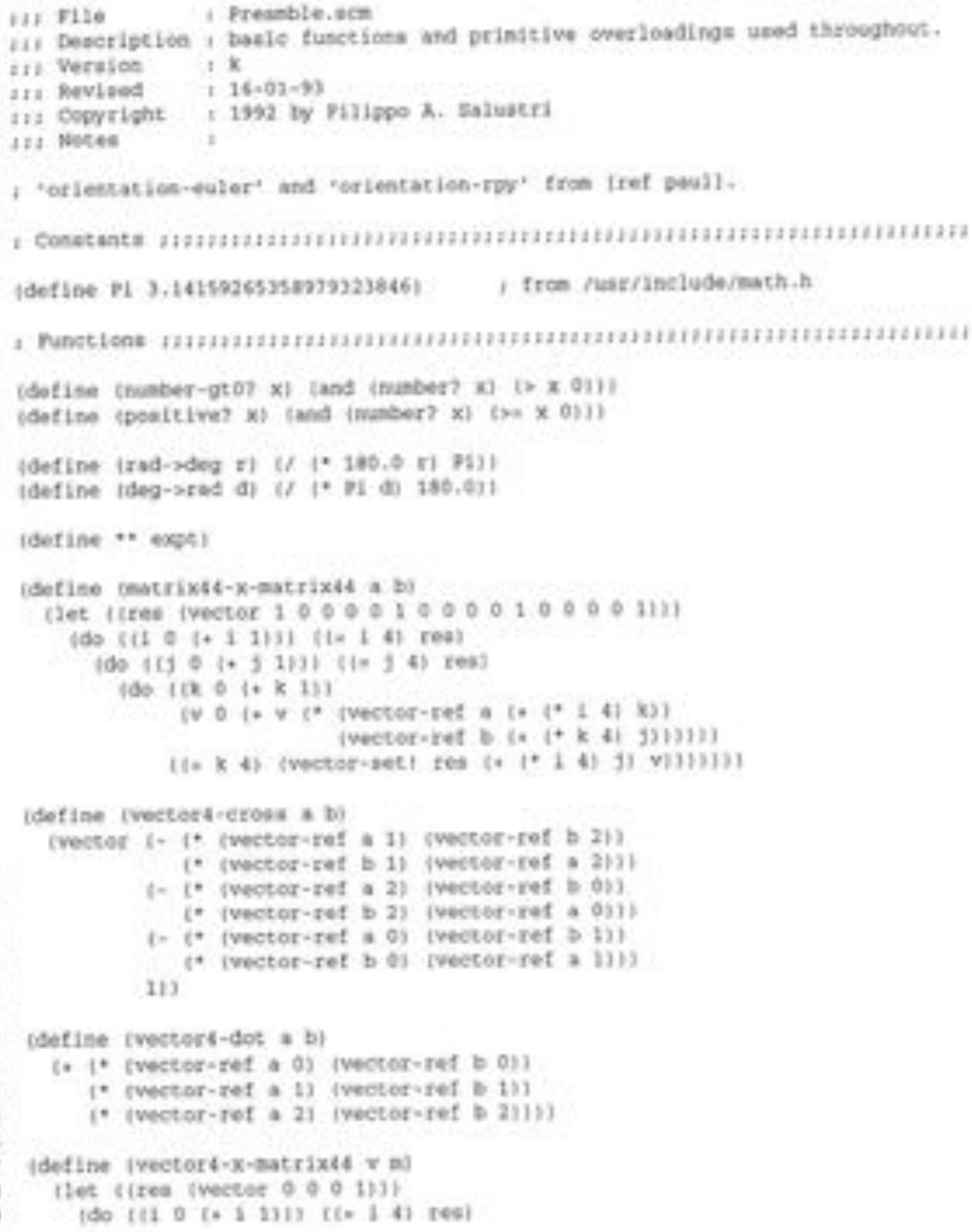




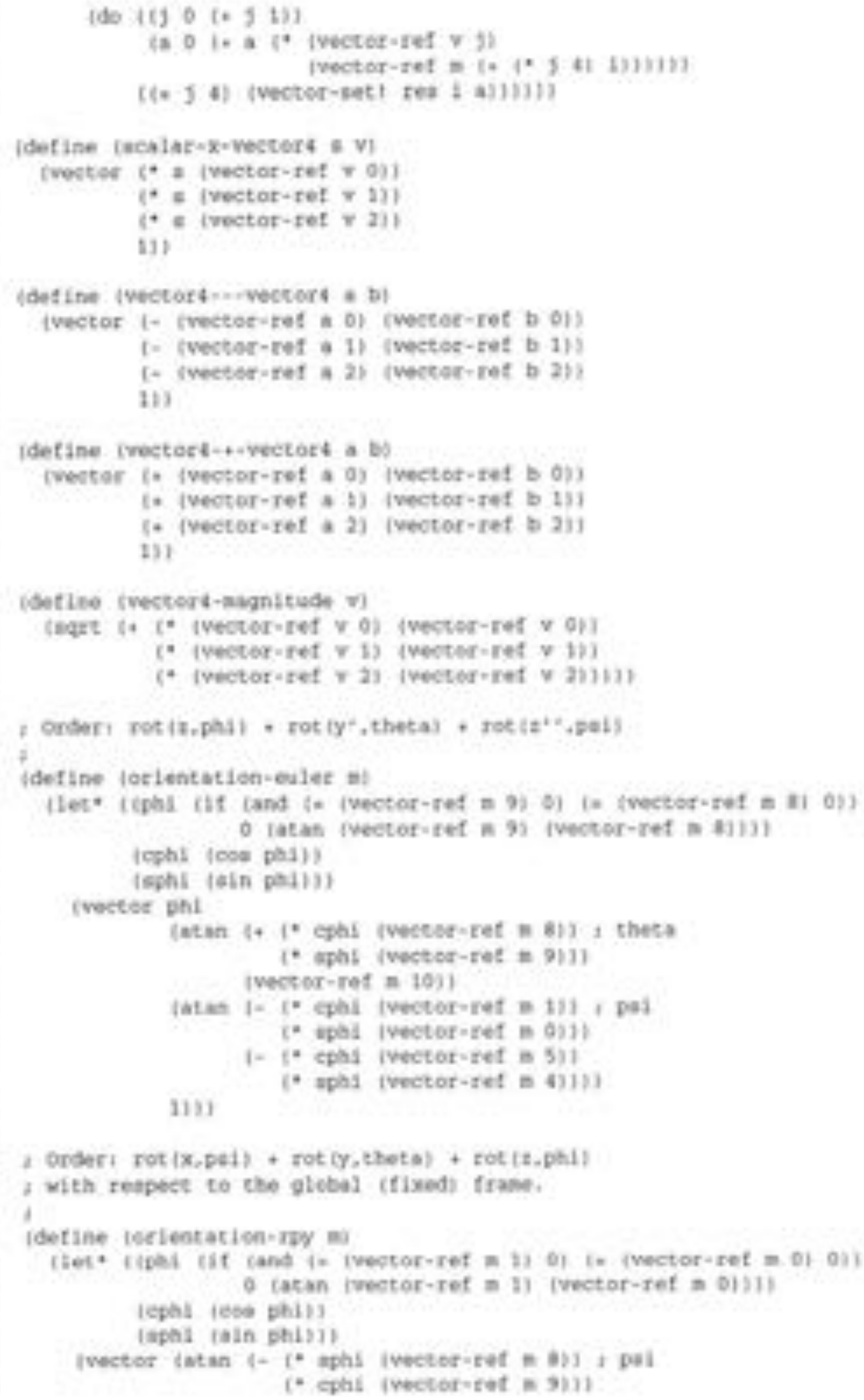




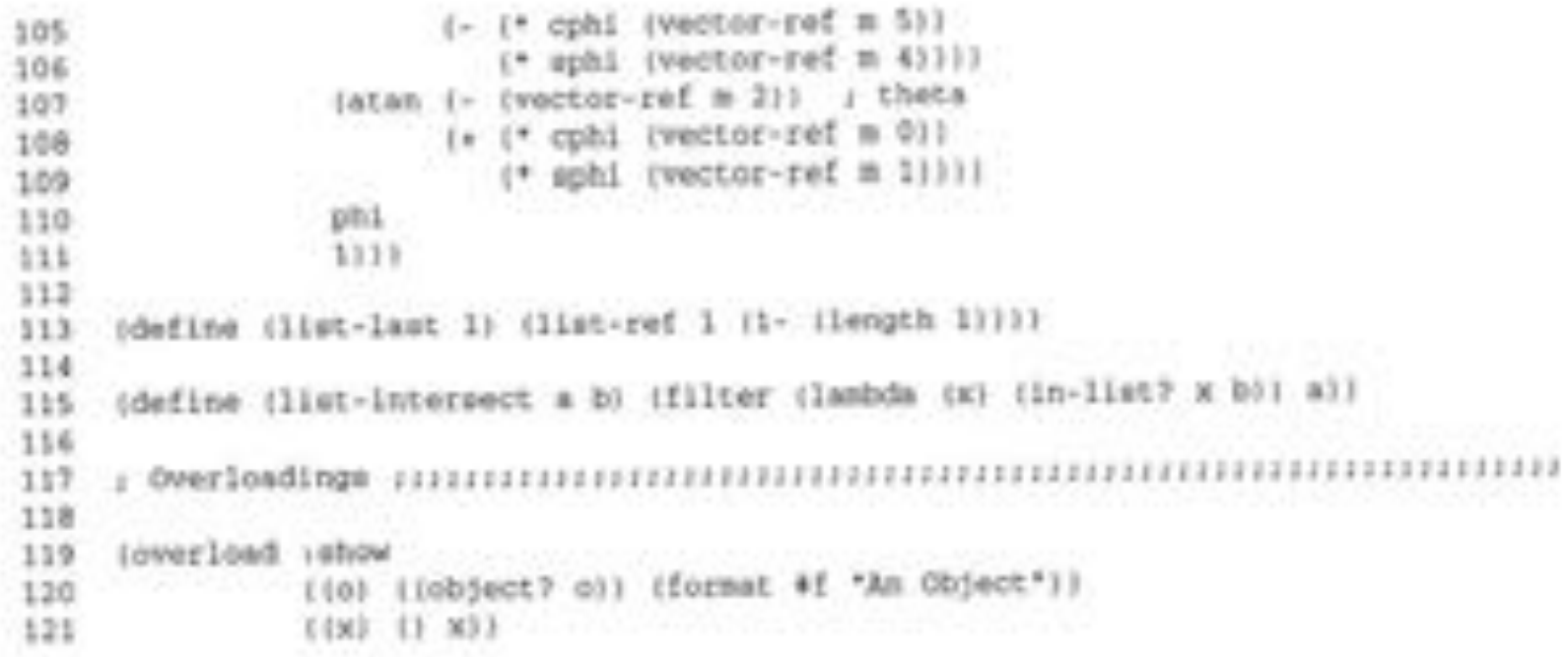




\section{Appendix B}

\section{Designer Prototype Library}

This chapter lits the ebject peototype definitions available in the Designer litery.

\section{B.1 Complex Numbers}

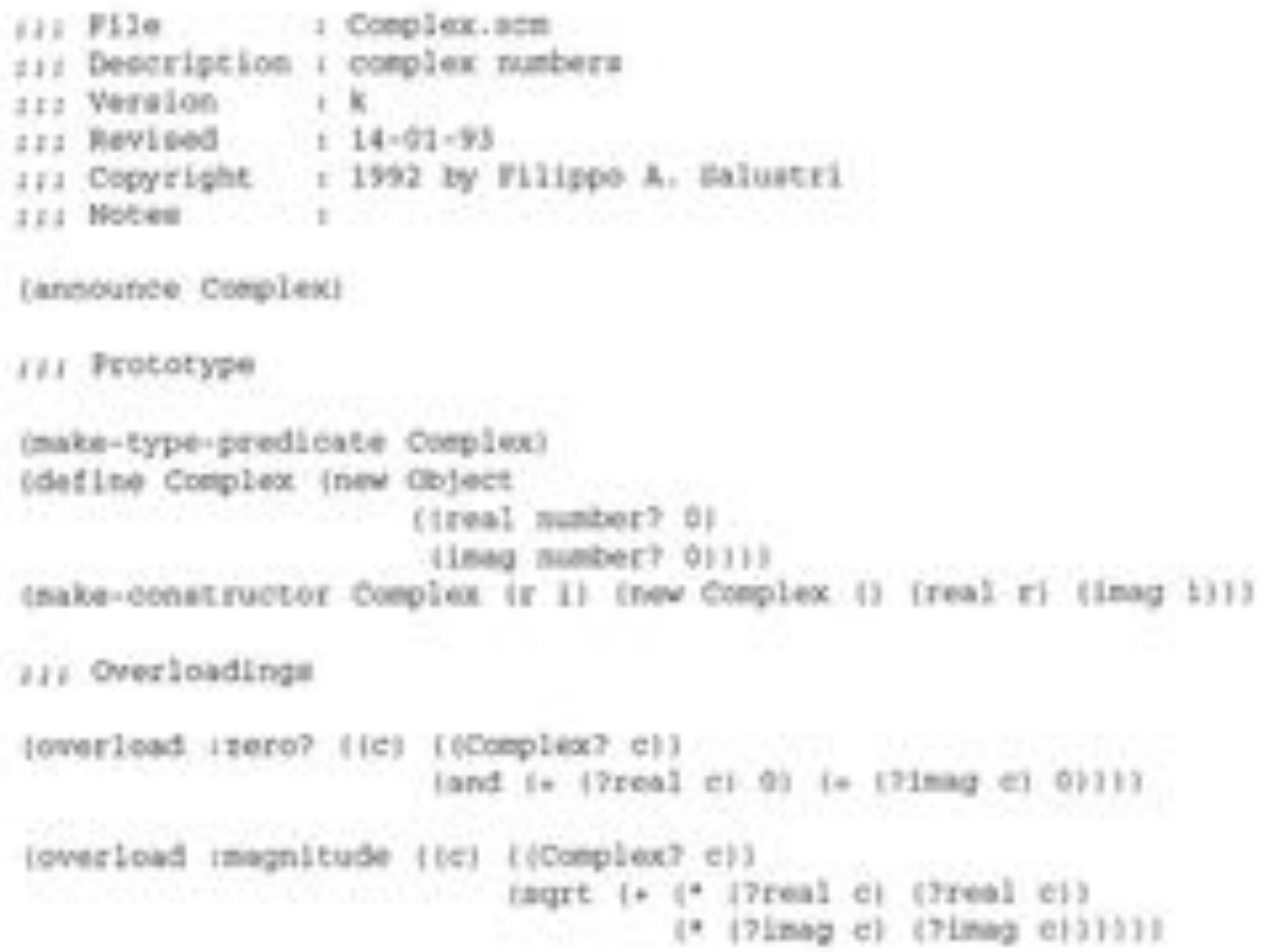




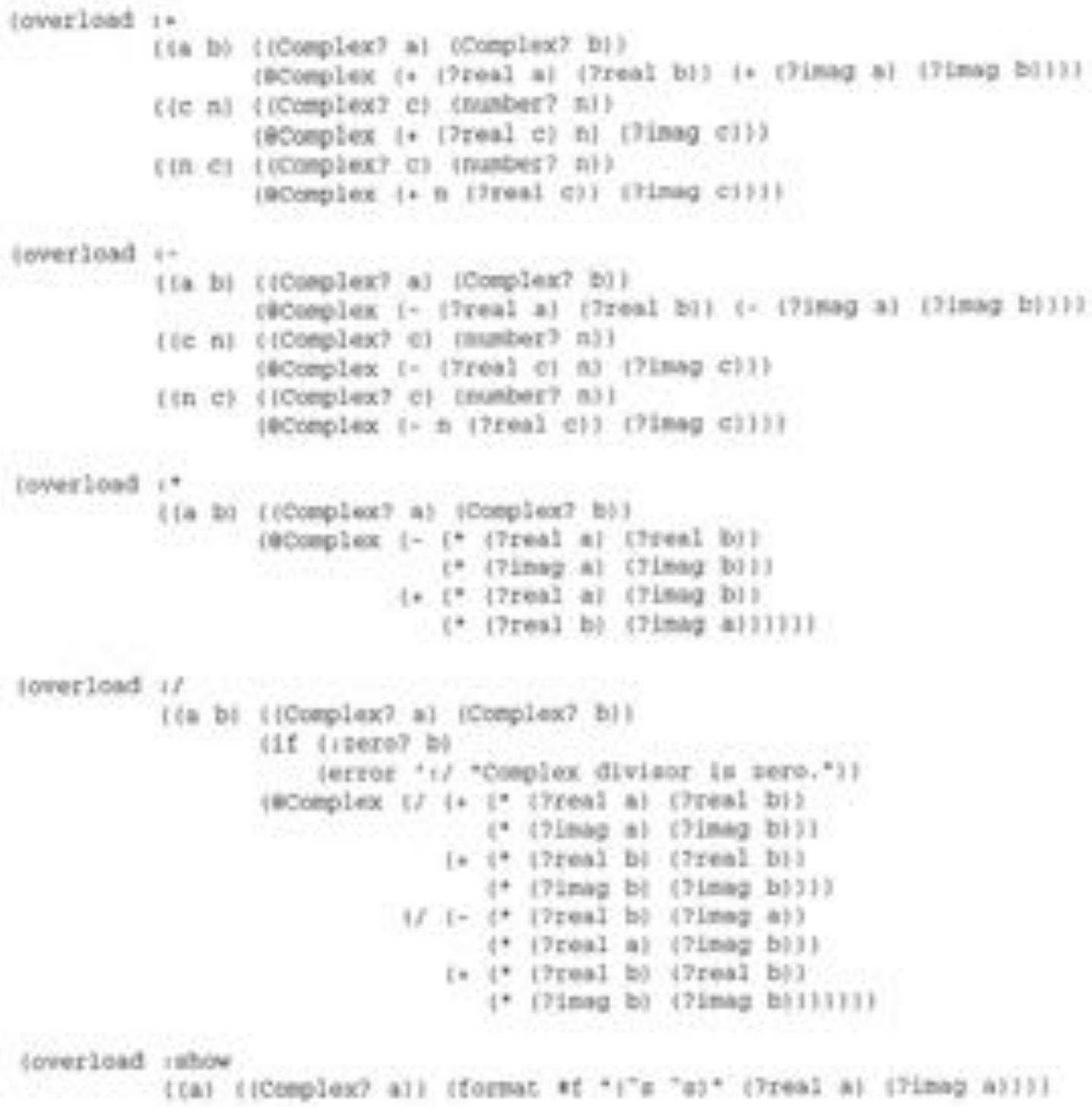




\section{B.2 3D Spatial Coordinates}

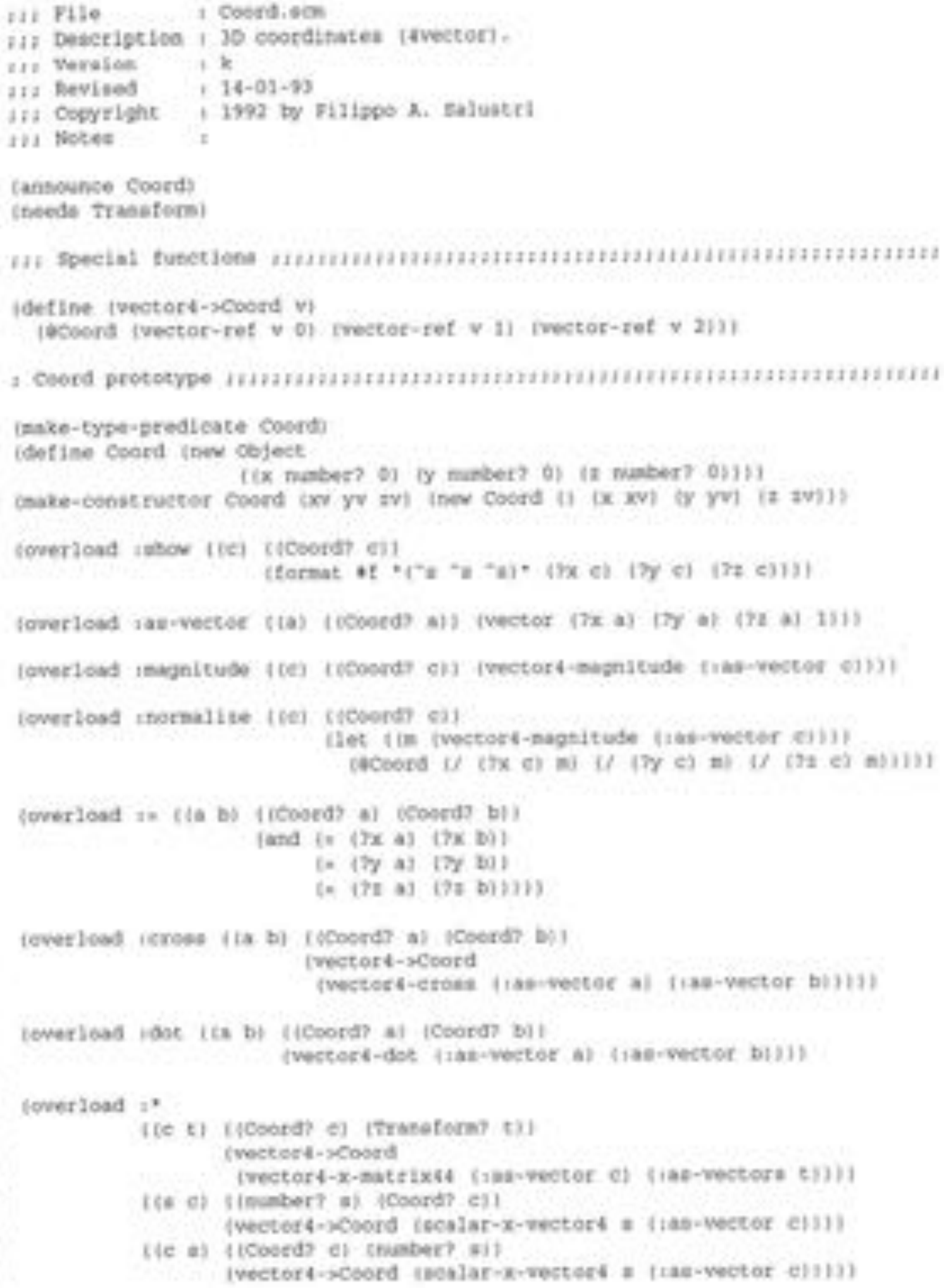




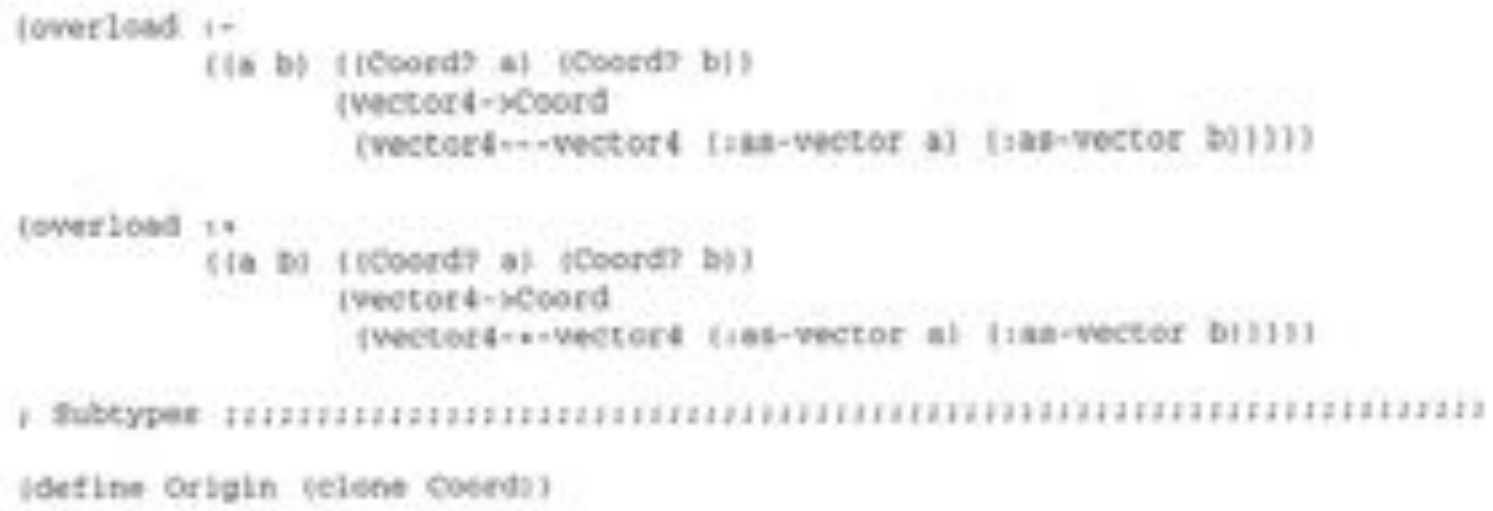




\section{B.3 Cuboid Parametric Volumes}

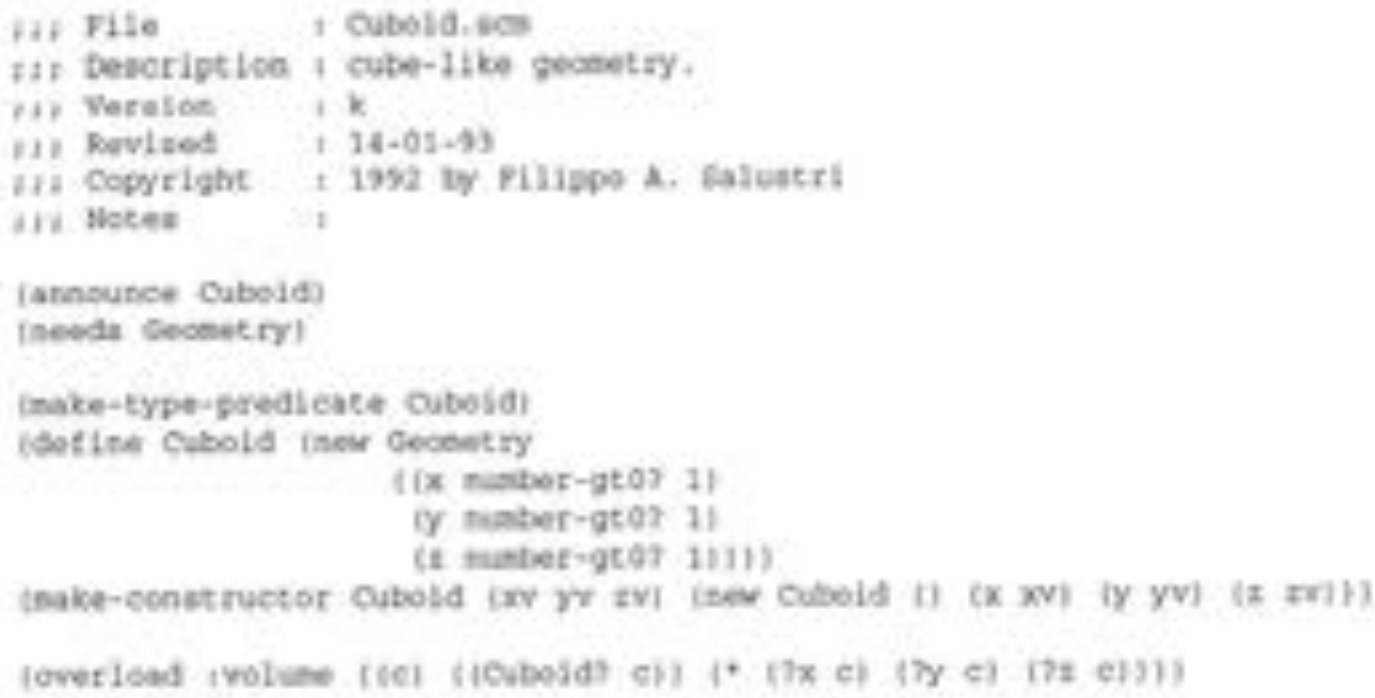




\section{B.4 Coordinate Frames}

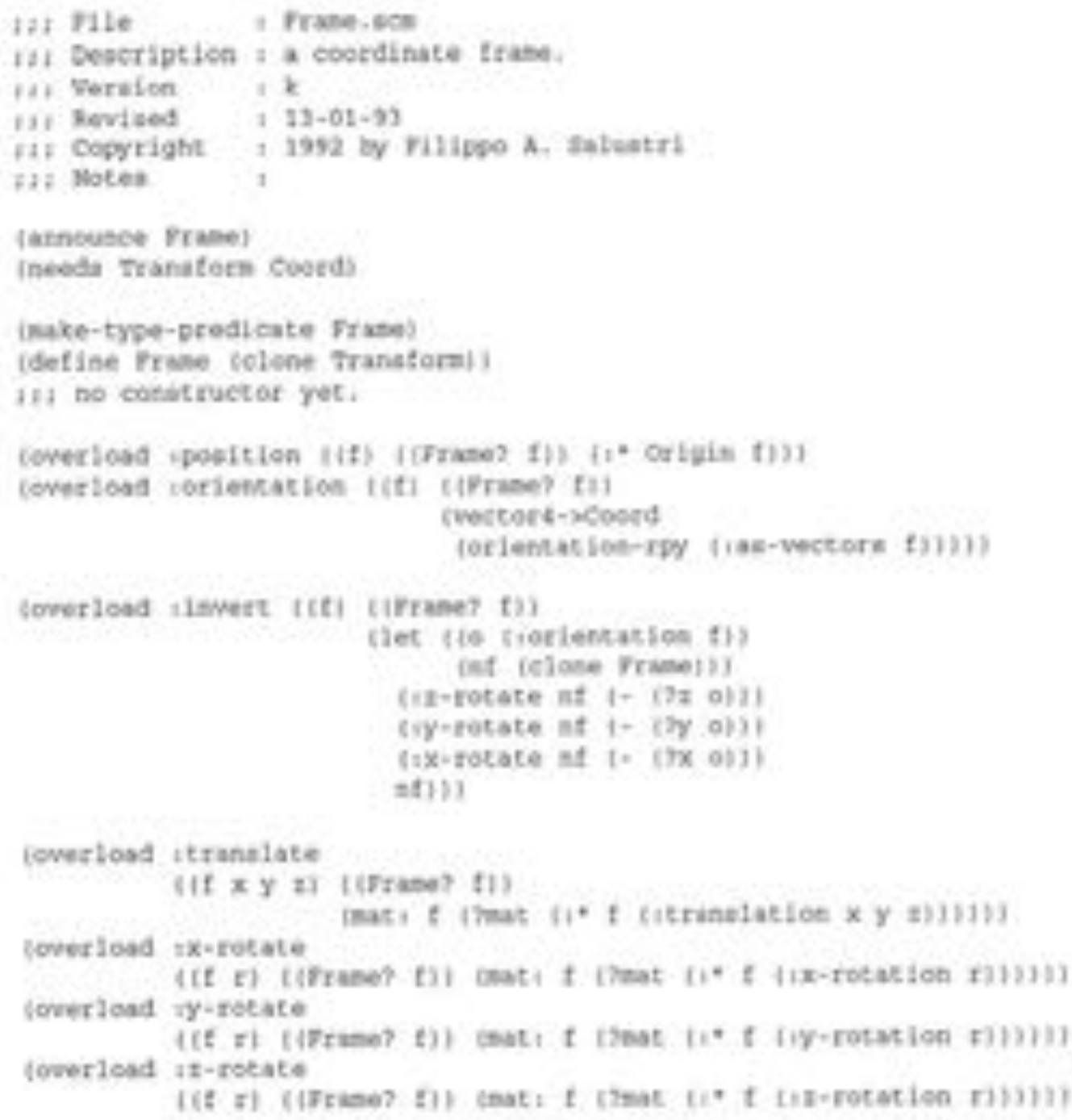




\section{B.5 Generalized Geometric Entities}

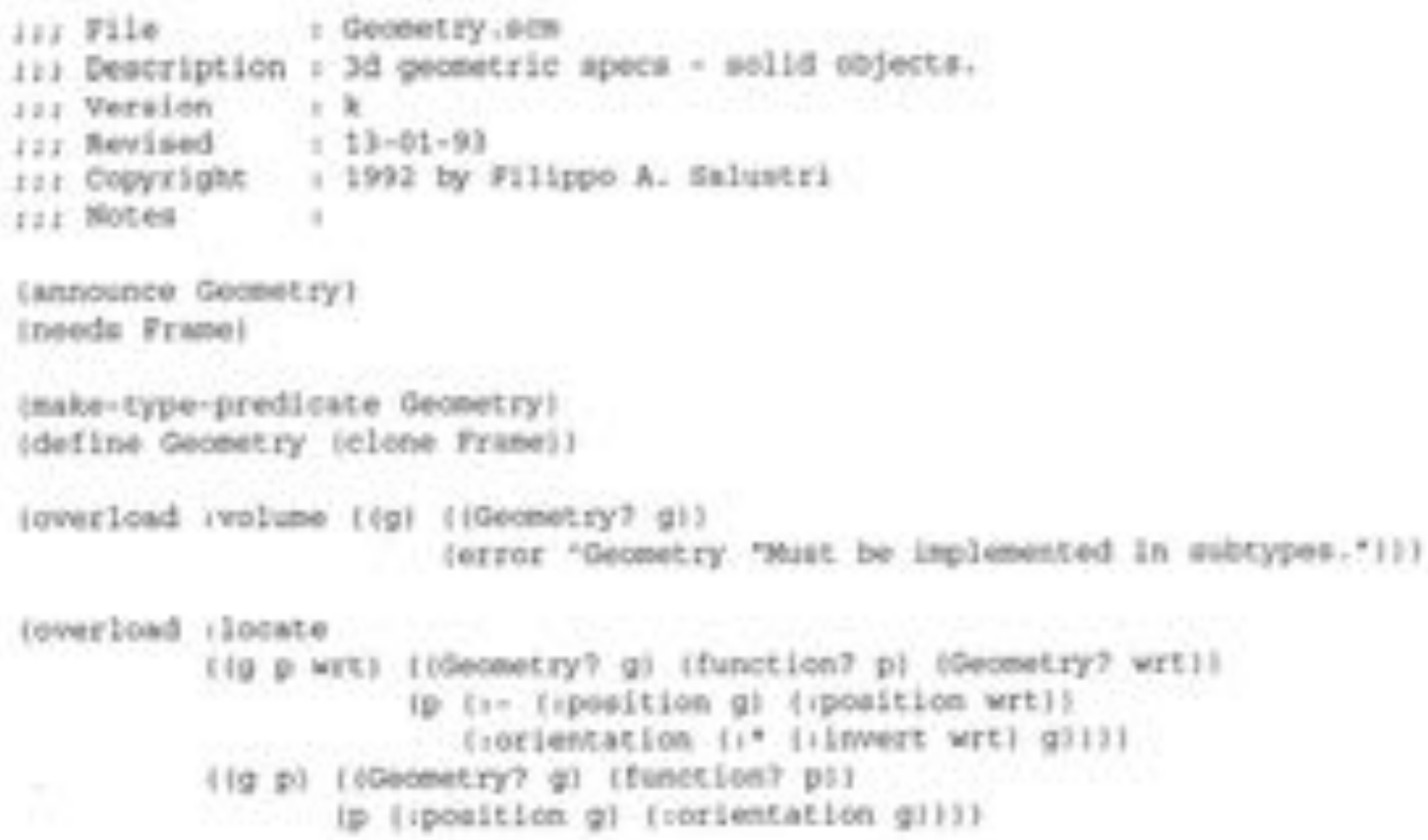




\section{B.6 3D Lines}

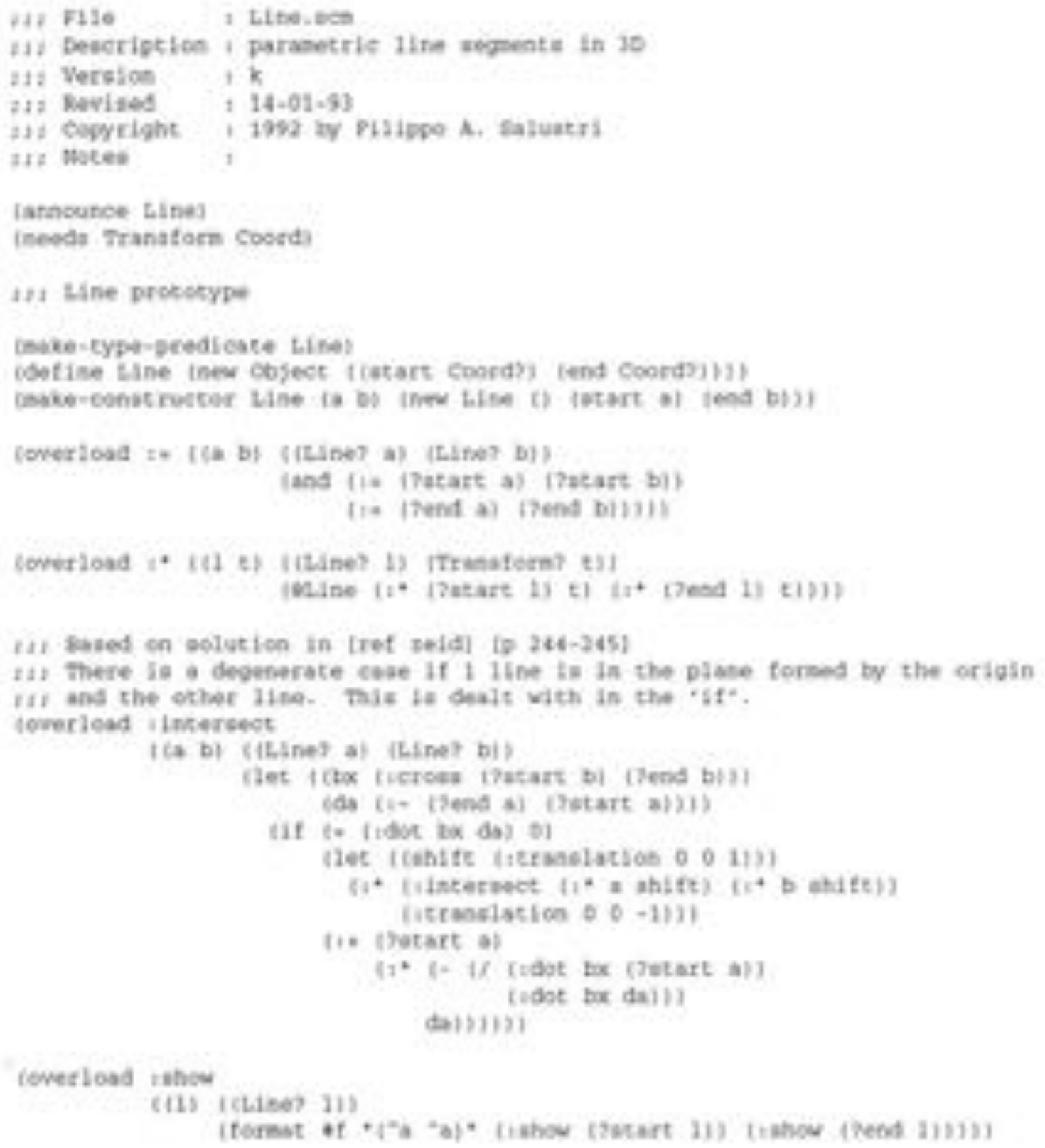




\section{B.7 Generalized Physical Parts}

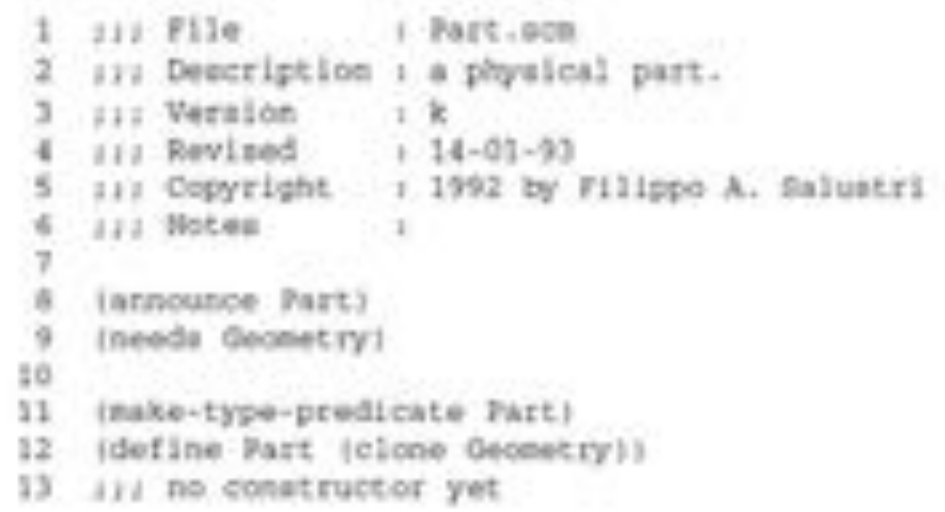




\section{B.8 Queues}

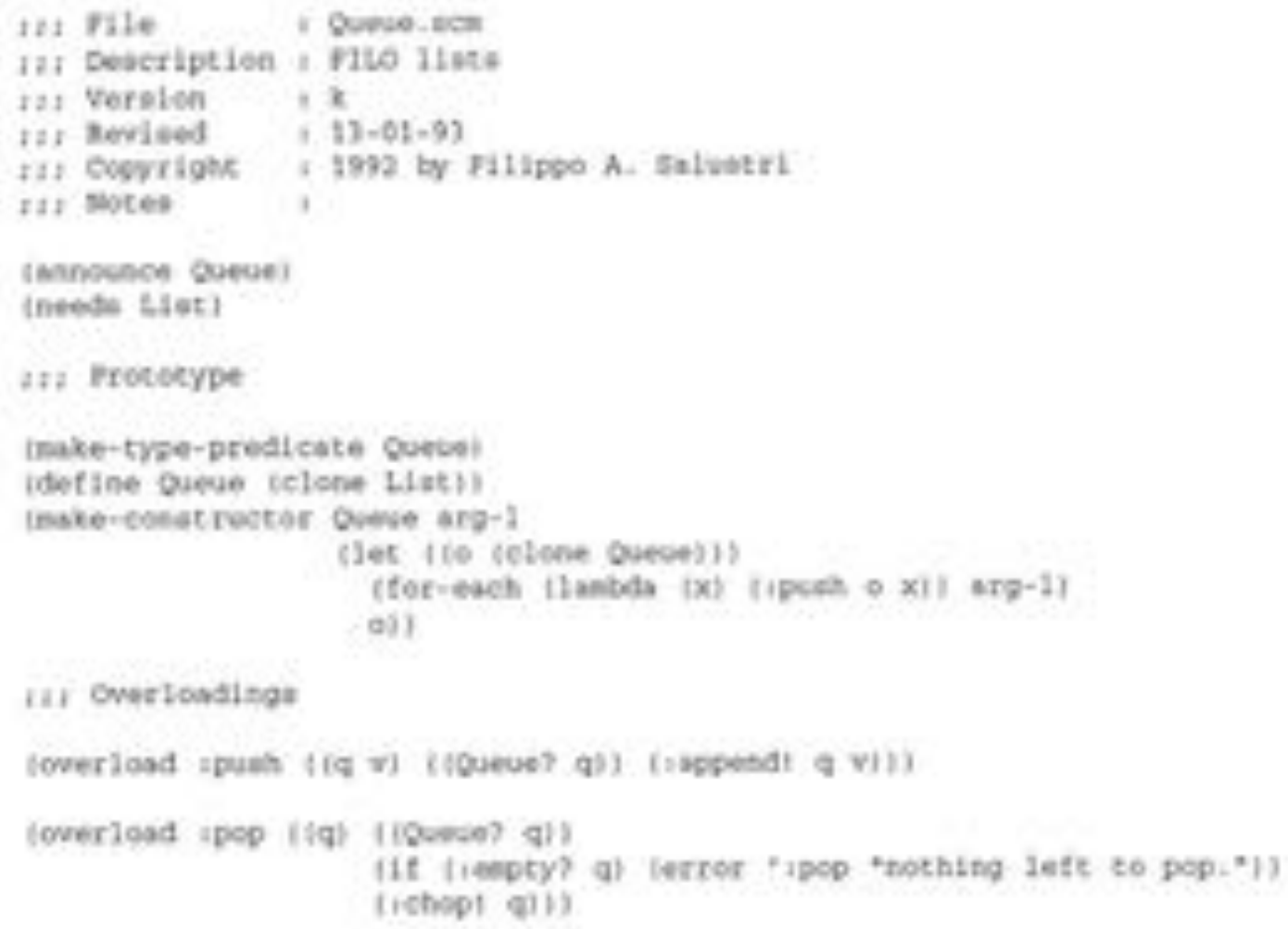




\section{B.9 Circular Lists}

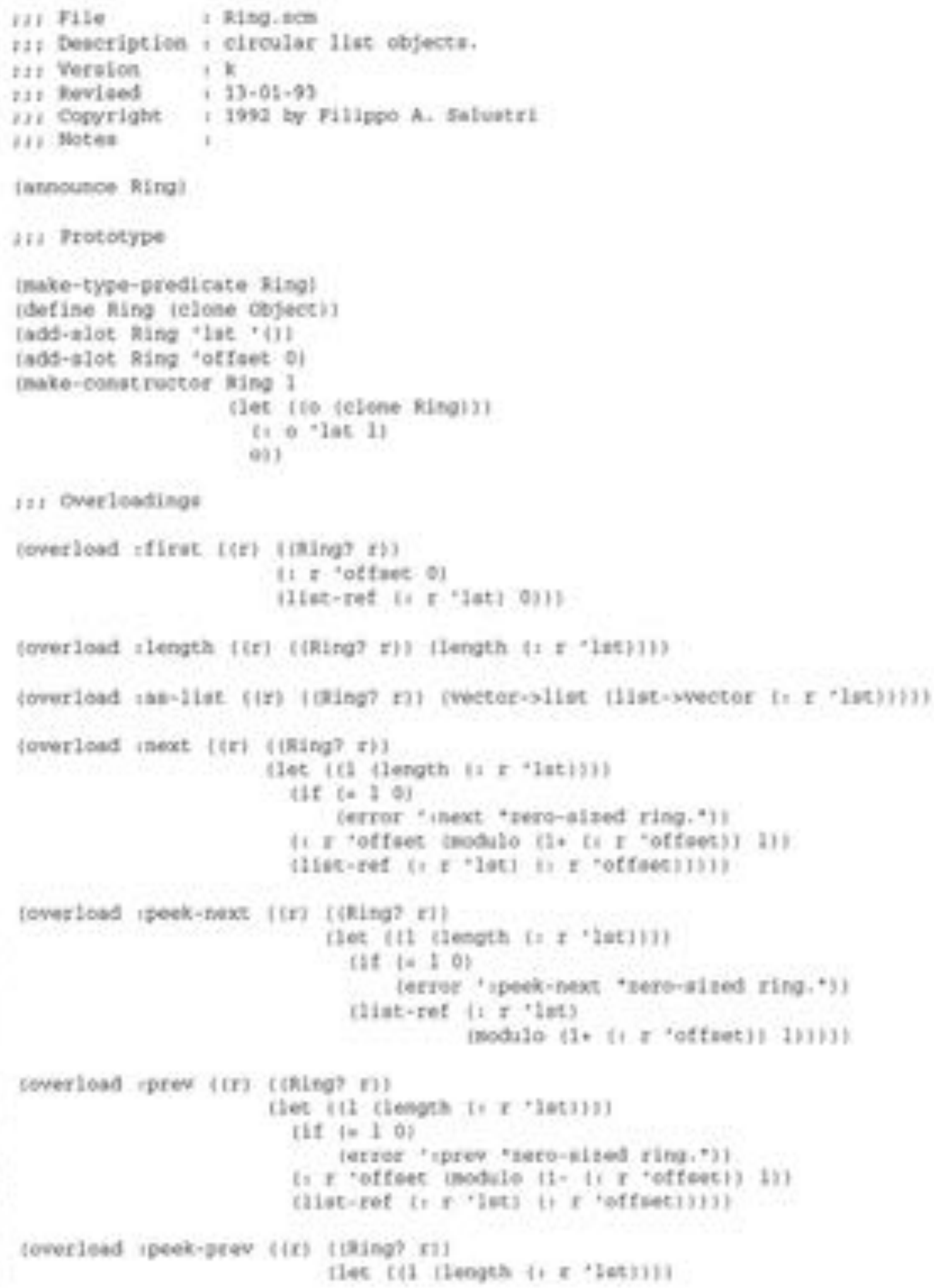


ate $\mathrm{in} a$ a)

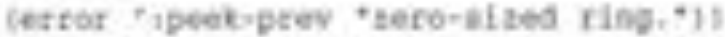
(1tat-ref for olat)

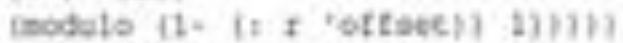




\section{B.10 Stacks}

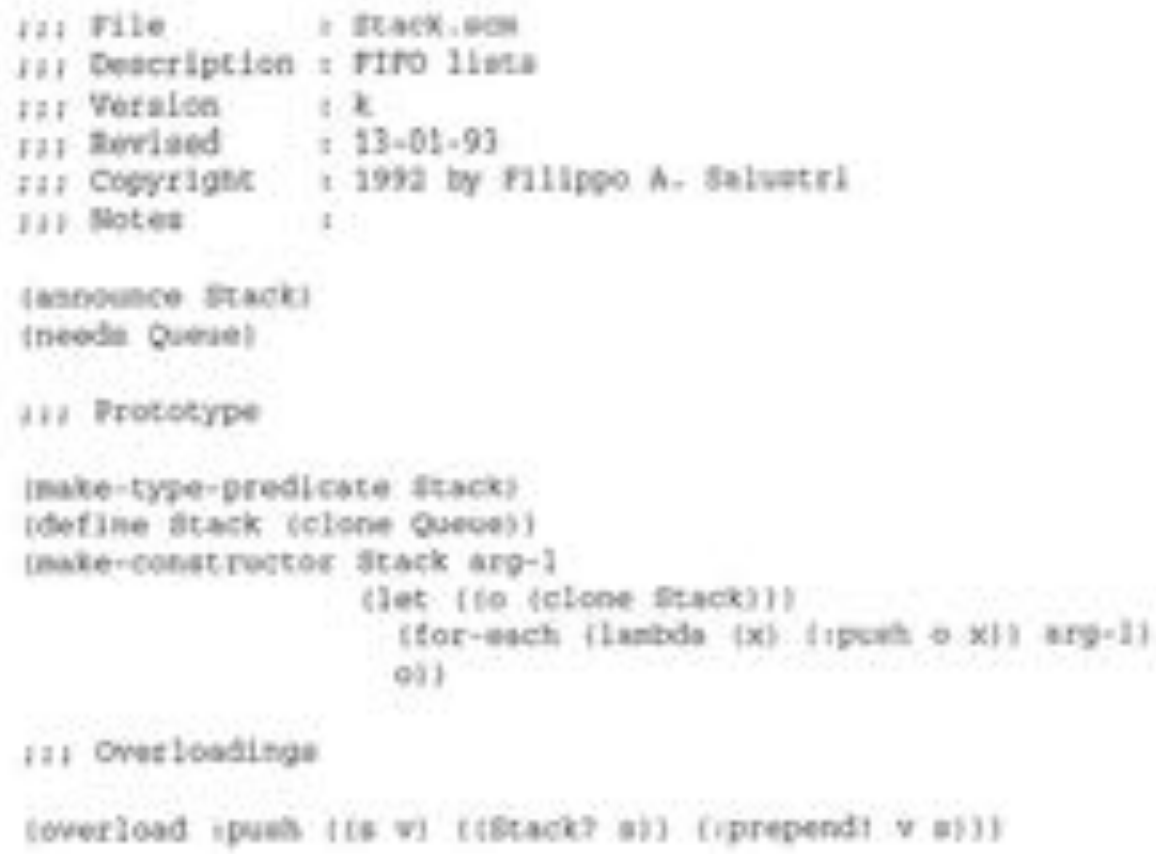




\section{B.11 Geometric Transforms}

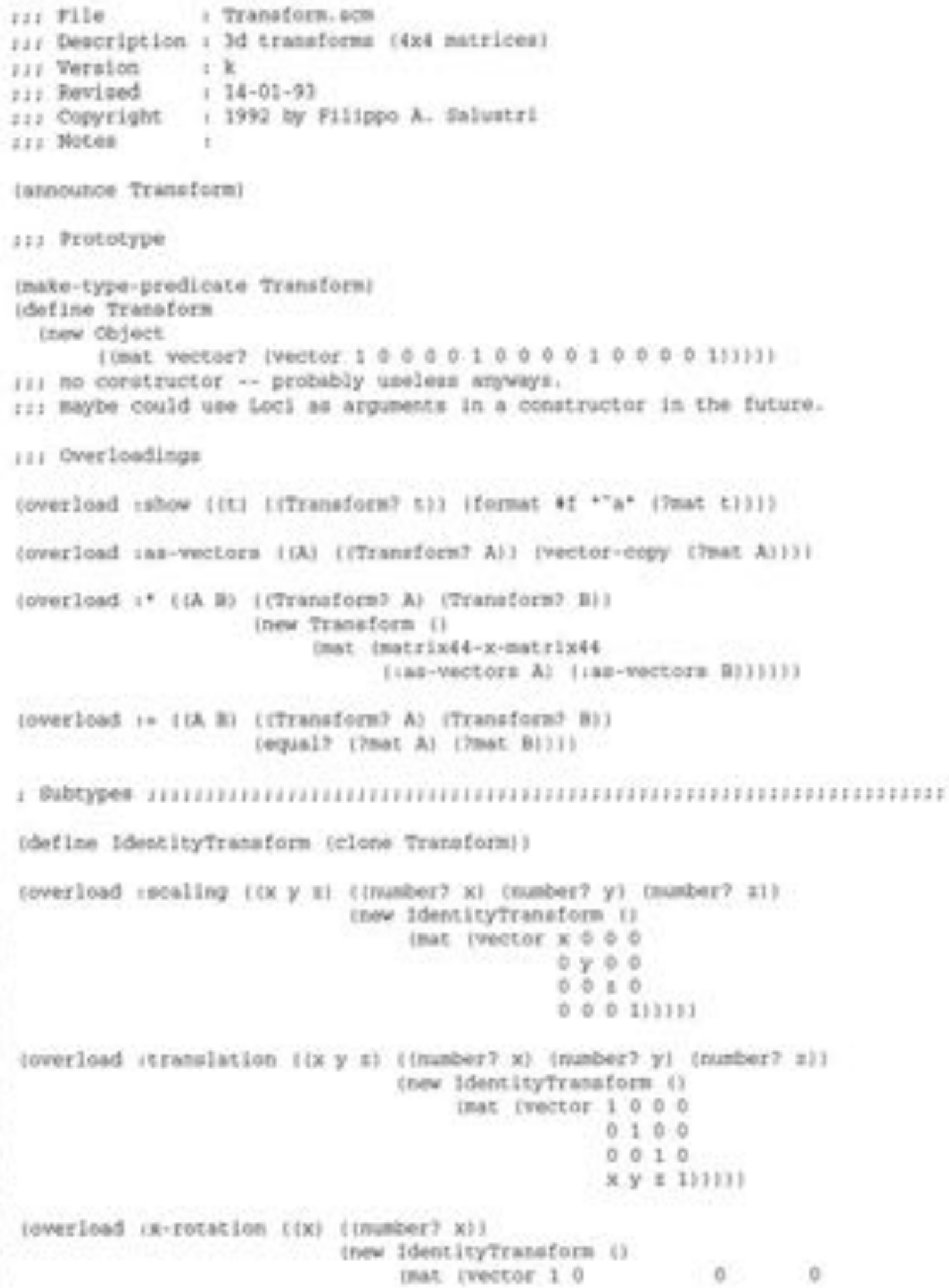




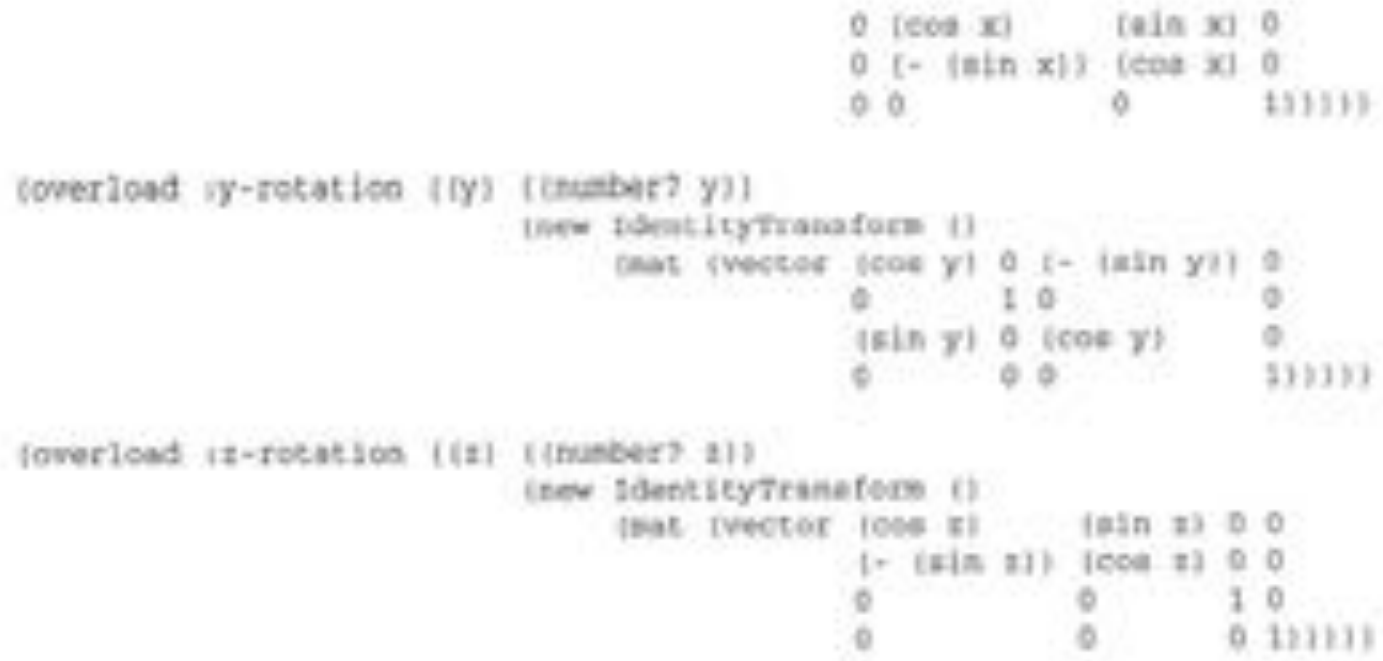




\section{Bibliography}

(1) Patrick Suppes. Awiowatic Sea Theory. Dover Publicatices, Inc., 1972.

[2] S. L. Femes and W. 1. Rasbort. Treanent of Engincering Design Corstraires in a Relational Data Base. Eegineering with Compaters, 1(1):27-37, 1985.

[3] Kenneth 1. Waldoxn. Sccost Condessions of A Designer, Mechaninal Engieeering, 114(11),60-62. 1992.

[4] Jota R. Dixos. The State of Education. Meckadical Engincering, puges 64-67, Feb 1991.

[5] R. M. Pact and A. J. McLood. The lmplementation of a Mechanical Enginecring Design traerface Using Engineering Feavures. Comparenalifed Evgierering Journol, pages 241-246. Dec 1988.

[6] Eugene S. Fergoson. Designing the World We Live in fiesearch is Enginereing Desigs, 4(1):3-11. 1992.

[7) Suresh Kenda, In Monarch, Fillip Sarpont, and Eswaran Subrahnanian. Shared Momory in Desizn: A Unifying Thene for Research and Practice. Reseanck in Engincering Desige, 4(1):23. 42. 1992 .

[8] Thoodose Bandasz and tbrahim Zeid. Propoing Analogical Problem Solving to Mocharical Desigr.

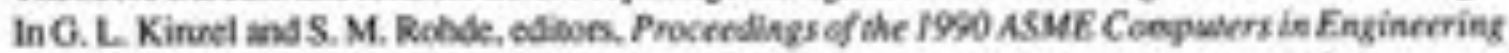
Cenfervice, paess 181-186. ASMEE, American Socicty of Mocharical Engineen, 1990.

[9] M. R. Duffey and 1. R. Dixn. A Pnozram of Research in Mechanical Engineering: Compuler-Based Models and Reposicntations. MDA Technical Repon 11.88, Mochanical Dreign and Autcenation Latoratory. Univenity of Mascactusens at Amhert, Amburst, MA, 1958.

[10] Commithee on Engincering Decien Theory and Methodology, Manufacturing Studies Boand, Coenmission on Enginoering and Tocheical Systems, and Nasional Rescanch Council. Inprovieg Englnerring Desizn - Designieg for Comperinive Admasage. Nationd Academy Pess., 1991.

[11] Joha R. Dison. New Coals for Engineering Edecation. Mechanind Fingihroring- pages 56-62. Mar 1991 .

[12] John E. Lockyer. Edocating for Awareness: An Aliemative to a Five-Year Curricelum, to be pesentod at the Eight Crodian Confenence en Faginecring Edecation, 1992. 
[13] J. R. Dixon, C. D. Jones, E. H. Nielwon, S. L. Luby, and E. C. Libardi. Knowledge Repecsertasion in Design. MDA Tedrical Repon 1-\$6, Mechanical Design and Astomation Laboratory. Universify of Massachusetts at Amher, Anhare, MA, 1966.

[14] Aart Biy. An Apgroach to Design Theory. In H Yoshikawa and E. A. Warman, edihoes, Design Theory for CAD, Foctedings from IFIP WO 52 Working Conderence on Design Theory for CAD. pages 3-31. Amadendam, 1987. North-Holland.

[15] Frank G. Pagan. Formal Specifeanioe of Prognaminieg Langauges: A Panonawic Priwer, PrenticeHall, Ink, 1981.

[16] Wrltard Van Oman Quine, Mathemadical Logk, Revised Edhion. Marvand Univenity Press, 1951.

[17] Zeriao Zang and Suepten L. Röe. Concepeal Design. Perceiving the Patiem. Mechanical Eszineerieg. papes 58-60. Jul t989.

[18] Thomas W, Malone and Jota F. Rockant. Computec, Networks and the Corperaticen. Scientiye Americas, 2643):128-136. Scp 1991.

[19] Robert Futwo. 199] Shows Incteased Amention wo Engineering Datahave Managerncet. in ASMEF Engineeriag Danthase Programe Newileter, Spring, 1992.

[20] Curistopher Fanell and Micheal Mandet. Call it What You Will, The Natien Neods A Plan To Nurture Growth. Alasioess Werk, page $\mathrm{NQ}$, Ape 1992.

[21] Thomas G. Dicticrich and David G. Unman. FORLOC: A Logic-based Architecture for Design. In John S. Gero, odioor, Expert Systems in Corpuster-Aided Desige. Proceedings from IFIP WO 5.2 contenence oe Expert Syctoms in Coesputer-Aided Desigh pages 1-17. Amsiendam, 1957. North-Holland.

[22] K. Ihii and P. Banas. Rule-baved Sensitivity Analysis. In John S. Gero, editor, Expert \$ystens is Compusen-Aided Design, Proctedings from IFIP WG 5.2 confenence on Expent Systems in Compuser-Abled Design, pagss 179-195, Amsendam, 1987. North-Bollixd.

123] Peser Struss. Maltiple Representation of Structure and Function. In Jobn S. Gero, editot, Expert

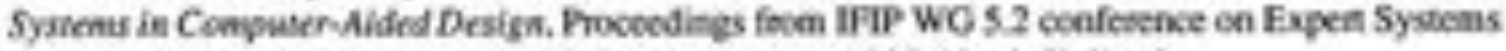
in Computer-Aided Design, puges 57-84, Anstendam, 1937. North-Holland.

[24] Douglas S. Green and David C. Bown. Qualitarive Reasoning During Design about Shape and Fit; a Preliminary Repont. In John \&. Gero, edisor, Bepert Systems in Corpuser-Aided Design. Proceedings foon IFTP WG 5.2 conference oe Expert Systems in Oompoter-Aided Desiga pages 93-112, Amsterdane, 1987. Nonth-Molland.

[25] Ceepory L. Ferves. Object-Onierbod Programming foe Eaginoering Sodraare Developmene. Englneering with Convuters, (21):1-15, 1990 .

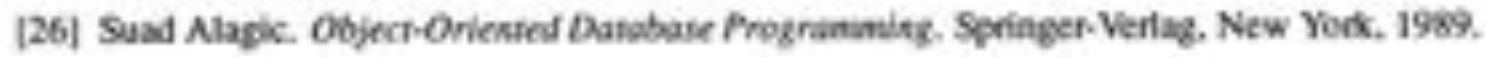

[27] Stanley B. Zobnik and Davis Maief. Fundomenals of Objecz-Orieswed Danabases. pages 1-36. The Morga Kaufmann Series in Data Mrnagoncmi Systems. Morgan Kasfinann, 1970. 


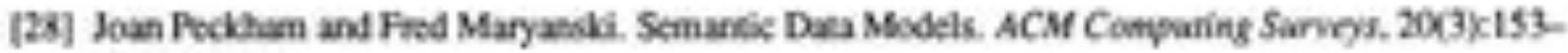
189. 1988.

[29] J. R. Dixen and M. R. Duffey. The Neglect of Enginoering Devign. Callornia Managewent Review, $32(2): 1-19,1990$.

[30] D. L. Hawla and IL. Neishlos. Knowlodge Acquivition for Effective and Elficlent Use of Eagineering Softwath. Engincerieg with Conpaters, 6:20:67-30, 1990.

[31] Nam P. Suh. The Principles of Desigs. Oxford Unnivenity Press, 1990.

[32] Soephen R. Brodley and Alice M. Agogino. Design Capsone and Infomextion Management foof

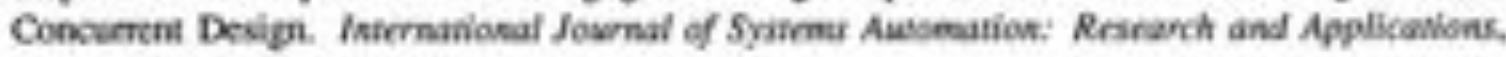
$102) 117-141,1991$.

[33] 1. R. Umartiya, S. P. Jonhi, and S. B. Joshi. An Inelligent Specifcasions Extraction Ineerface for Structural Desigh Eeginerites with Conpuers, 603)153-165, 1990.

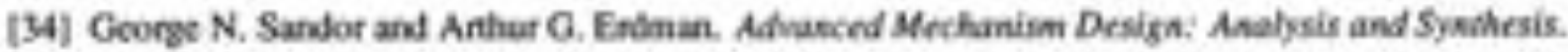
Prentice-Halt. Inc. 1984.

[35] M. F. Oselup and J, R. Diven. Compuner-Based Models of Mochanical Design Processes: A Sumenary of Curnets Research. MEDA Technical Repon 9.8k, Mochanical Design and Autoesicion Laborasey, University of Massachusetts at Amhern, Amhunt, MA. 1985.

[36] John R. Dixon. Why We Necd Doctoral Programs in Design. Mechasical Engineering. pages 75-79, Feb 1992 .

[37] J. R. Dixen, M. R. Duffey, R. K. Inan, K. L. Mounier, and M. R. Oetup. A Froposed Tasenexy of Moctunical Design Problens, In V. A. Tipris and E. M. Palton, edikors, Proceediegs of ehe 1988 ASME Conpaters in Enginecring Cosference, pages 41-46. ASME. American Society of Mochunical Engincen, 198s.

[38] Jchn R. Diwen. On Research Methodology Tounds a Scicntific Thoory of Enginecring Design. MDA Technical Repont 8-85, Mecharical Design and Aubomation Labocatory. Univesilty of Massachusetrs at Amhert. Amhuns, MA. T958.

[39] Tetwo Toetigama and Himoyuk Yoshikawa. Extendod General Desiga Theory, In H. Yoshikawa and E. A. Waman, editors, Desige Theory for CAD. Proceedings froat IFIP WC 5.2 Woding Conlerence on Design Theory for CAD, puges 95-130, Amsendam, 1987. North-Holland.

[40] Allen C. Wand. A Recursive Model for Managing the Design Process, In James R. Rinderle and David G. Ullman, editors, Desigs Theory and Methodology, ASME Design Aubomation Conferences, pages 47-52. Now York, 1990, ASMEE.

[41] Owen R. Fawel. Espanded Use of Fenction Language in Mechanical Design. In N. Ropplewell and A. H. Shah, editors. Proccedieges of ate Thineenth Conadian Congress of Applied Mfechanics. pages 692-693, Winipef. Man, 1991. Prins Matagenent, Lud. 
[42] J, J. Cunriaghum and J. R. Dewoe, Designing With Fexures: The Onigin of Feabures. MDA Tectnical Regon 3.85, Mechanteal Design and Aztomarion Labontory. Univenity of Mascactusetts an Amhert, Amhurst, MA, 1958.

[43] J. R. Diwn. E. C Libundi, and E. H. Nielsen. Unresolvod Rescarch lsuses in Developenent of Design-With-Featuses Syctems. MDA Technical Repot 2-89. Mecharical Desien and Actomition Laboracry, Univenity of Massachasents at Amhert, Anhuns, MA, 1989.

[44] J. R. Dixco, J. J. Cunninghan, and M. K. Simmons. Research in Designitg with Featuses. MDA Technical Report 4-87. Mochanical Desipn and Astomation Latorabog, University of Mas. sachusets al Aahert. Ambura, MLA, 1987.

[45] John R. Diwon. Desigging will Fearures: Building Manufactoring Krowlodge into More Inselligeat CAD Systems. MDA Technical Repon 2-88, Mochanical Desigh and Ausmation Laboratory. Univenity of Massachasetts at, Amhert, Amhurst, MA, 1958.

[46) Raghu Kariathi and Dana Nau. An Appoosch to Addressing Goometric Feature Inieracticas, In

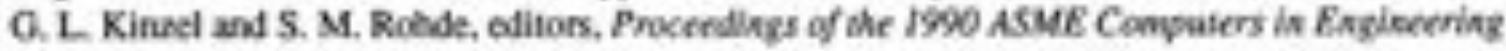
Conferrect, pages 243-250. ASME, American Society of Mochanical Eegineer, 1990.

[47] Kosuke tshii. Role of Compuieriad Compatibility Analysis in Simslrancous Engineering Ener-

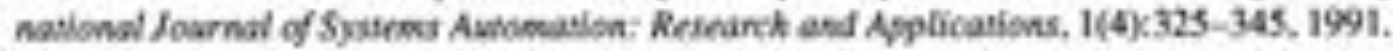

[48] Janal A. Abdalla. Venion Manapencnt Necds for Suractural Enginctritg Design. Eegincrieg winh Cespowers, $733 \times 131=142,1991$.

[49] M. K. Zamarian, S. L. Femes, C. R. Thewalt, and S. Finger. A Featued based Appoush to

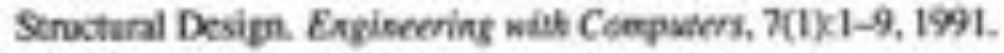

[50] R. E. da Silva, K. L. Wood, and J. A. Beaman Intencting and Inerfeatufe Refarionships in Englneering Design for Manufacturt. International Josrnal of Syicus Aatomawion: Resinarch and Applicawions, 1(3)-263-236. 1991.

[S1] Jami J. Shah and Mary T. Rogen. Funclional Requifenents and Cosceptual Design of the FeacareBased Modelling System. Conpusen-Aidrd Enytherrieg Jeurnal, papes 9-15. Feb 1988.

[52] Froseric Gisoometti and Then-Chien Chang. Nrancwork to Model Pafts, Assemblies, and Tolerances. Intersarional foursaf of Systows Aatomation: Feseanch aed Applications, 1(2):161-181, 1991.

[53] P. H. Ot. H. A. ElMaragly, and L. Hamid. FDCL: A Feature Basd Desien Description Language. In W. K. EIMaraghy, W, P. Secting, and D. G. Utiman, editors, Desigs Theovy and Meshodology, ASME Decign Autonation Cenferences, peges 53-64. New York، 1959, ASME.

[54] Ming-Trong Wang. Marjala B. Waldree, and R. Allen Miller. Prototype Integrated Featute-Based Desiga and Expen Process Farring Sysacn for Tumod Parts. International Josinal of Sysicne Aaromawon: Research aed Appilcations, 1(1);7-32, 1991.

[55] James Bowes and Pener O'Cinaly. A Technology for Builing Life-Cycle Design Advisers. In Q. L Kinzel and S. M. Robde, editors, Procendiegs of the 1990 ASME Convaters is Engiecering Conference, pages 1-7. ASME. Amserican Society of Mechanical Engincers, 1990. 
[56] Martie Hastwisk and Blair R. Dewnie, On Object-Oriented Durabases, Materialined Vews, and Concursem Engineering. In V. Saxeas, edlwer, Engihterieg Danabases: As Eegineering Resouvce. puges 93-97. ASME, Anerican Society of Mechanical Eegincers. $199 \mathrm{~L}$.

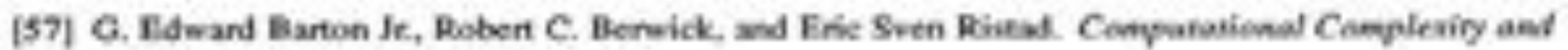
Nanaral Lanswage. MIT Press. 1987.

[58] A. M. Agogins and A. S. Almpren. Syabelic Competation in Computer-Aidod Optimat Design.

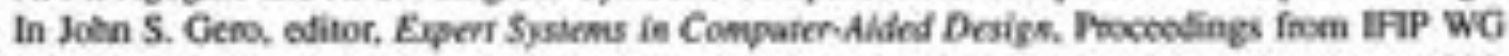
5.2 conference en Expert Systens in Compuier-Abded Devizen, papes 267-284, Amsendam, 1937. Nonth-llolland.

[59] D. Navinchandra and D. H. Mark. Dexign Exploration Throgh Constraint Relacution. In John S. Gero, editor, Expert Systews in Compster-dided Desies, Proceedings froen IFIP WG 5.2 conference on Exper Systems in Computer-Aided Derign, pages 48 1-\$09, Anstendan, 1987. Nonth-14celand.

[60] Darid A. Hocitacl and Wei-Hua Ciene. Systems for Unified Life-Cycle Mechanical Enginoering Design: Shared-Toct Anchinectures Verous Distributod Tool Aschimostures. Enginecring with Compaiers, $6(4)-211-222,1990$.

[61] Johe Ramusuth. Shape Optimization and Compuler-Aided Design. Inkernational Journal of Sysicms Aarowasion: Research aed Apoificanione, i(1) 33-45. 1991.

[62] 1. K. Wu, F. N, Choong, K. K. Choi, and E. J. Haug. Data Model for Simulatiob-Based Design of Mechanical Sysiens. Insernational Journat of Systemu Ashowatiow: Resnanch aed Applicatiens, 1(1):67-57, 1991

[63) George J. Fisotman and Comelius T. Leondes. Constrain Thoory, Pant I: Fundsmentals, IEEE Transactiaes on Sysienu Sclence and Cybernenks, sse-5(1):48-56, 1962.

[64] George 1. Friedman and Conclius T. Lovedes. Constraint Thoopy, Pay II: Model Graphs and Regutar Refasoes. IEFE Thaedactions as Sysems Sclence and Cybernerics, ssc-5(2):132-140, 1969.

[65] Gooego 1. Priodman and Comelius T. Locedes, Coestraint Theory. Part III: Inequaliny and Discrete Relwions, IEEE Thaniacrioss en Systrens Science and Cybernevics, ser-5(3):191-199, 1969.

[66] Panos Y, Papolanbros and Douglass 1. Winde. Principles of Opwinat Desige: Modeling and Conpuarioe Cambeldge University Press. 1985.

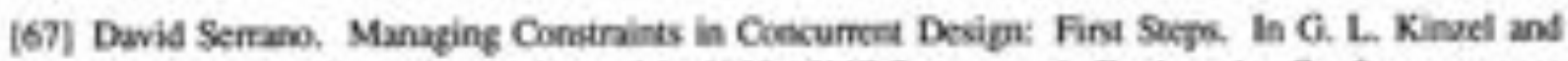
S. M. Rohle, edison. Procendiezs of the IS90 ASvE Conputers is Engincering Confenence, papes 159-164, ASME, American Society of Mochanical Engincers, 1990.

[68] Susan Darting Uitan and Lois M. L. Dekanbre. Costraint Aralysis: A Tool for Fisplaining the Semantics of Cosaplex Cejcets. In X. R. Dintich. ediber, Adnances in Object-Oriented Databases

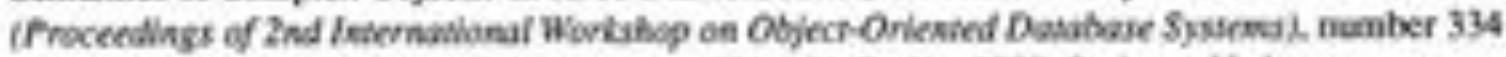
in Lecture Notes in Computer Science, peges 156-161. Bertin, 1988, Springer. Verlag. 


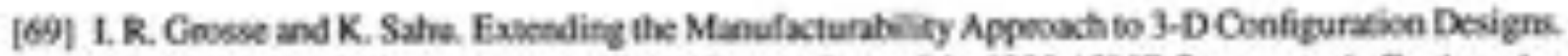
In G. L. Kinel andS. M. Robde, edinoes. Procendiegs ef the 1990 ASME Conputers is Eingincering Conference, pages 25-32, ASME, American Socicty of Mochanical Engineen, 1990.

[70/ lames R. Rinderle and V. Krishnan. Constrain Reaweing in Coccurtent Design. In James R.

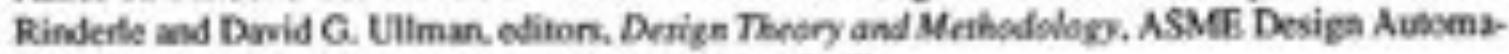
tion Confesences, pages 53-62, New Yok, 1990. ASMT.

[71) Wald Habib and Allen C Wand. Proving tho Labeled leserval Calculas foe Inferences on Cacalogs. Is James R. Rinderle and David G. Uitman odison. Design Throny and Merhodology. ASME Design Automaxion Coeferences, papes 63-68, New York, 1990, ASME.

[72] Joha D. Wascon and James R. Rinderle. Impewing Mechanical Design Decisions with Altemase Fomulations of Condraints. In James R. Rinderle and David G. Uthanan, edinos, Design Theary and Methodolozy, ASMB Design Aubmatice Conferences, pages 69-75, New York, 1990. ASME.

[73] Peter J. G. Ramadge and W, Marray Wishiom. The Conool of Discrete Event Systems. In Proceediezs of the IEFE, velume 7 , pages 81-95. IEEF, 1939.

[74] B, A. Brandis, W. M. Whehan, and B. Benhabib. Marufactaring Cell Supervisory Coetrol - A Timed Discrete Event System. In International Cosperrece ae Robotics and Awomation, papes 531-536. IEEE, 1992.

[75] Martin A. Fogle and J. Kirk Wh. A Relxive Condinue Fornulation for Variational Solid Modeling. In James R. Rinderle and David O. Uliman, edison. Desige Throry and Methodology, ASME Design Automation Conderences, pages 11-18. New Yok, 1990. ASME.

[76] Ewald Lang. Kaj-Uwe Cansemen, and Gocliny Simmons. Modellieg Sparial Krowledge on a Lirzuistic Rases, Number 481 in Lecture Noes in Antifial Intelliponce. Springer-Verlag, 1991.

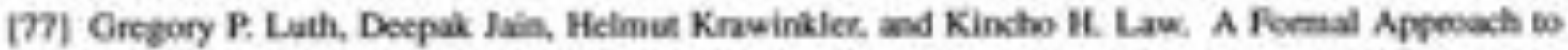
Auscmating Concepoual Stroctural Design. Part I: Methodobogy. Enginecring with Ceoputers. 7(2), $79-39,1991$.

[78] R. H. Crawford and D. C. Anderson. A Computer Regnexpetation for Modelited Fetdtock in Design Processes. In G. L. Kindel and S. M. Rohde, odimos. Procindlings of the IS90 ASNE Coesputers in Engineering Coverence, pages 165-170. ASME, Anctican Socicty of Mochanical Englincers, 1990.

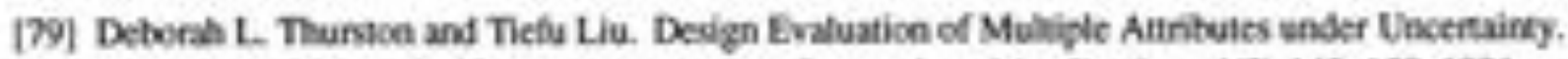
International Jownal of Systrms Aubananba: Reseanck and Applications, 1(2): 143-159, 1991.

[80] Irving M. Copi. SymboWl Logic. Macraillan. 1979.

[81] Kosuke Ishii. The Role of Compuiers in Simultanesus Enginecring. In G. L Kinoel and S. M. Pohde, efitors, Procendings of the 1590 ASME Coepuners in Eegineering Conference, pages 217-224. ASME, American Soxicty of Mtochunical Enpineen, 1990.

[82] Ravi M. Rangan. Using Infonnation Theory to Moddi Design Processes Suppeeted by Information

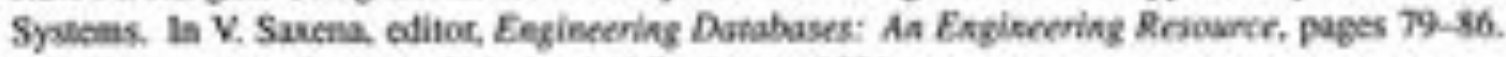
ASME, American Socicty of Moctueical Enginctr. 1991 . 


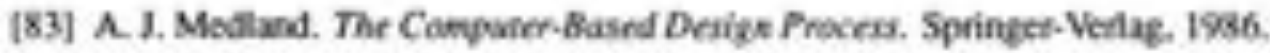

184] Joveph Convance. DFML: Leamife to Devign Sor Marnafacture and Asicmbly. Mechaninal Eegintcrieg, 114(5) $70-74$, May $19 \% 2$.

[R5] Seven Ashley, Applying Taguchi's Quality Engineering To Technology Develspment, Mechasical Engineering, $114(7) 58-60$, July 1992.

[86] David G. Unman. The Mechandcal Drsign Process. MoGraw-Alill, 1992.

[37] Wojoloch Gaspanki. Uedersanding Desige: The Prasiologinal-Systemic Perspertive. The Syseeras Inquiry Series, Inenystems Putlicarion, 1964.

[38) Steven D. Eppinger, Dariel E. Whitoncy. Robert P. Smith, and David A. Getala. Orgariring the Taks in Complex, Design Projocts. In James R. Rinderfe and Daxid G. Ulinan, edinos, Design Theory and Mrihodologo, ASME Design Automation Conferences, pages 39-4s. New York, 1990. ASMEH.

[59] R. M. Puell and A. 1, Mcleod. Engincering Fearure Dexcripcion in Mechanical Engincering Design. ComputenAided Eegienering Journal, pages 160-183, Oct 1988.

1909 Srikanth M. Kannpan and Kun M, Marshek. Design Synthetic Reasening A Mecthodology for Mechanical Design. Resranch is Fngincerieg Design, 2(4):221-238, 1991.

[91] Richard Sause and Gratam II. Rowell. A Design Process Model for Compober Integrated Structural Enginocrine. Enginecrieg with Cowputers, 6(3):129-143, 1990

[92] William H. Slautertack. The Manufacturing Envinement in the Year 2000, in Ausfacr 6 Cowerence Proceedings, pages 21:1-21:9. Michigan, U.S.A. t9s4.

193] Charles M. Easman. The Contribution of Dura Modeling to the Puture Developeners of CADVCAM Databues. In V. Sawena, ofitor, Engieerring Dasabases: An Engineerieg Resounce, pages 49-54. ASME, Americin Socicty of Mochanical Enginecr, 1991.

[94] Charfes M. Fasimas, Alan H. Bond, and Scoen C. Cose. A Formal Aprooach for Product Model Information, Resenant in Eegiecring Design, 2;65-80, 1991.

[95] Charles M. Eastman. A Dota Model Analysis of Modularity and Extensihility in Bulding Datahaves. Buifding asd Envinosesen, 27(2):135-148, 1992.

[96] C. M. Eastman. A. H. Bced, and S. C. Chase. A Data Model ber Design Datataves. Is 1. S.

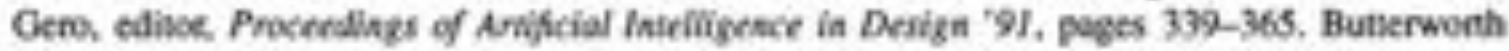
Heinemann, 1991.

[97] Cuales M. Easoman, Alan H. Bond, and Scon C. Chase. Application and Evaluation of an Enginctring Data Model. fiesounch is Engincerieg Dersign, 2:185-207, 1991.

(98) Alan H. Bond, Oodes M. Eastman and Scoti C. Chase. Thoorstical Foundations of EDMS Froduct Design Models. working paper. 1992. 
[99] Bertrand Meyer. Inwoduction so ake Theory of Progrowunieg Langwages. Prentice Hall latemurional Series in Compoter Sclence. Prentice Hall inc. 1990

[100] Saiysd Z. Kamal, H. M. Kanndikar, Fanokh Mistree, and Douglas Muster. Knowledge Representakion for Discipline-Indeprndent Decieson Making, In John S. Geno, edinor. Eipert Systend in Comparemdided Desisw. Proceodings fom IFIP WG 52 coefenence on Expert Systems in Computer-Aided Design, pages 289-318, Amstendam, 1987. North-Hollant.

[tot] R. H. Crawford and D. C. Andenon. Modular Emvinorencnt for Indegratine Preliminary Mechanical

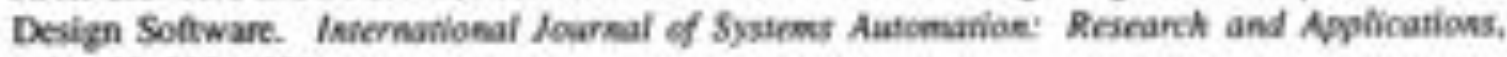
1(2) $183-202.1991$.

[102] Tetsuo Toeniyama and Paul J, W, Ten Hagen. Otgainization of Desipn Knowicdge in an letelligent

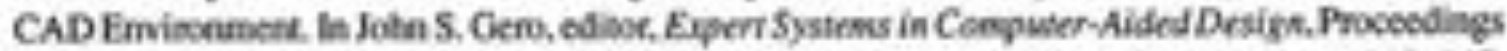
from traP WO 5.2 confenence on Expen Systens in Compuler-Aided Design, pages 119-147. Anstedian, 1987. North-Hollant.

[103] B. T. Dorid. Multi-8spert Sysems for CAD, In P, J. W, ten Hagen and Tetsoo Tomiyana edisen.

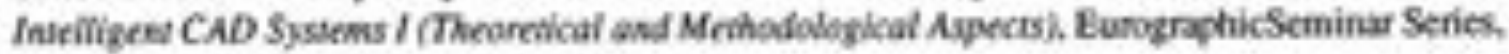
papes $37-67$. Berlia 1987, Springer-Vtalag.

[104] 1. R. Koegel. A Theoretical Model for Inbelligent CAD, In P. J. W, ven Hagen and Tecouo Tomiyama, editors, IntriWgent CAD Sysuener I Theanewical and A/estodological Aspects), Eumgraphic Seninar Series, pages $206-223$, Bertin. 1987. Springer. Verlag.

[105] Y, E. Kalay, L. M. Swendloff, and A. C. Harfmarn. A Knowledgebased Compotable Model of Design. In Jotan S. Ceno, ediner, Enprre Syanews is CompareruAded Design, Procecdings from IFIP W6 5.2 ceeference on Expen Systens in Conpuier-Aided Design, pages 203-223. Amotendan. 1987, Nocth-Hollind.

(106) Kincho H. Law, Thierry Barsalon. and Cio Wiederthold. Management of Cotuplex Siructural

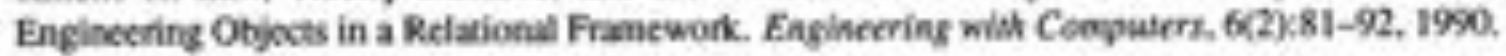

[107] Guidong Han, Sctsoo Onouga and Hiroyuki Yanouchi. The Apolication of Keowledpe Base Technology to CAD. In John S. Gero, edince, Expers Sysiews is Cerputer-Ailind Dersign, Proceed. ings from IFIP WO 52 conference on Espent Systems in Compuber-Aided Design, pages 25-51. Amstentam, 1957, North-Holland.

[108] E. F. Codd. The Relarional Model for Dasabase Managewenr; Versiow 2. Adtison-Wesley, 1990.

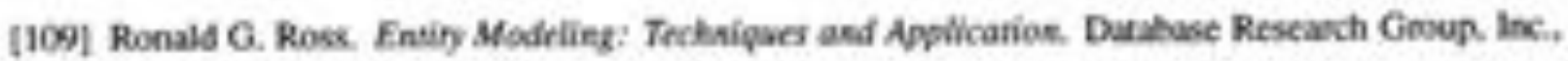
1987.

[1109 James J. Osell. Modelling Objost Uxing Biaucy and Eaticy-Relationchip Models. Joarnal of Object-Oriened Prognanusing: $5(3): 12-18$, Jun 1992 .

[111] Richant Hull and Roger King. Scmarsic Darabuse Modcling: Survey, Apslicarions, and Reseach kswes. ACM Compating Surnot, 19,3)201-260. 1957. 
[112] Kincho H. Law, Gis Wiederhold, Niki Sianbela, Walter Sujancky, David Zinemond, and Harvinder Singh. Archilecture for Managine Design Objects in a Shareable Relational Framework. lewerna.

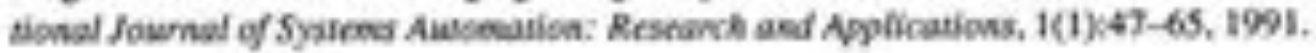

[113] David Siemple. Abolfo Socomo. and Tin Sheand. Foenalixing Objects for Desahases wsine ADABTPL. Is K. R. Dinitich, edibor. Advancer is Obyho-Orirekd Danabases (Proceedings of 2nd

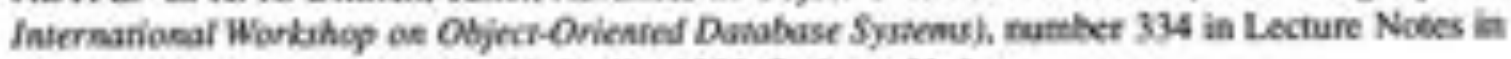
Computer Science, pages 110-128, Bertin, 1958. Spritger-Verfag.

[114] Duvid L. Stubes and P. Derek Enes. Modulariasion: Mrefaheicating a Process Pant. Mechaniral Enginerieg. papes 63-65. Nov 1990.

[115] no asthor given. Coject Oriented Databuses: An Engineer's Perspective. in ASME Engineering Datahave Program Newslener, Spring. 1992.

[116] saff. Objective Dena. Scientific American, Science and Business Department. Mar 1992.

[117] Johnathan S. Colice and Joha L. Dascanio, II. An Intcysod. Inselligent Design Envinuement. Engiecering with Convuters, 71):11-22, 1991.

[118] Won Kim. Ietroduction so Object-Oriesud Dowabases. The MrT Press, 1990

[119] Hertert B. Welcker. Modeling in the Design Proces. In W. Dele Compeon. oditor. Design and Anabsils of Integrated Manafartaring Syotmu, pages 167-199. Waduinglon. DC, 1986. National Acadcany Publishing

[120] G. Sunde. A CAD Syatan wid Declarative Specificatioe of Shape. In P. J. W. ten Hapen and Tetsoo Toniyama, dilon, Intelligent CAD Systems I Thearnieal and Meshodological Aspectah. Eurograptic Seminar Series, pages 90-105, Bertin, 1957, Springer-Verlag.

[121] Stuart Waswon. Relational Gecmetry-a New Generation of Two-Dimensiond CAD Compuner: Aided Engineering Joarnal, pages 169-172, Aug 1988

[122] Walid Keirour, Jahir Pabon, and Robert Young. Integrating Parametric Goometry, Features and Variabional Modcling for Coscepted Design. In James R. Rindcrie and Dewid G, Ulinxs, editors. Design Theory and Methodologs, ASME Design Auscmation Cenfenences, pages 690-691. New York. 1990, ASME.

[123] Xin Dong and Micheal Wouny. Managing Feature Type Dependency in a Feabure-Based Modeling System. In G. L. Kincel and S. M. Rohde, editon, Procendings of the 1990 ASME Cemputers in Englitecring Cosference, pages 125-130, ASMEE, Anerican Society of Mocharical Engincers. 1990.

[124] U. Roy and C. R. Lia. Exablishment of Functional Relationships berween Prodect Compoents in Ascenbly Dushase. Compater-Alded Desige, 20:570-580, Dec 1958.

[125) Uwe Weissfleg. CIM Dictioearice: Aa Evelutionary Approsch bo CTM Data Ireegration. In V. Saxena, ediuge, Enginecring Dasabasex: Av Eeginering Resower, pabs 71-78. ASME, American Society of Mochanical Engincta. 1991. 
[126] Ravi M. Ragean and Robent E. Fulion. A Data Management Stranczy so Control Design and Manufacturife Infoeaxion. Engineerieg with Compaters, 7(2):63-78. 1991.

[127] Gerald Jay Sussman and Gay Lewis Sucke Je, CONSTRAINTS - A Languge foe Expressing

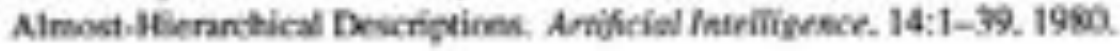

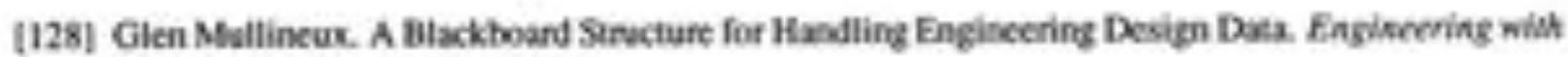
Computers. 73):185-195, 1991.

[129] Philip M. Sogent. Materials Data Ineenchasge foe Component Manufacture. Engiecering witt Compaters. 6(4) $237-247.1990$.

[130] David Serrano, Comtraint-Bused Concurnent Design. Internatioval Journal of Systews Awrowation: Reseanch and Applifations, I(3)287-304. 1991.

[131] Julian Jaynes. The Origie of Cassciossess is the Breabdown of the Bicaeseral Mied. Univenity af Torones Press, 1976.

[132) Yopesh Jalenia and D. Lomberti. Use of Espert Systems in the Design ef Themal Equiproent and Processes. Restanst in Enginerisg Desizs. 2(4)-239-253. 1991.

[133] L. Popescu and M. B. Zaremba. An Efficieat Scanch Method for Expont Robot Centrol, International

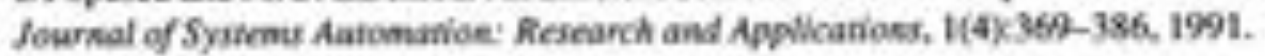

[134] Enn H. Tyuge. Merging Conctptual and Expen Knowlodge in CAD. In Ithn S. Gero, editot, Elpert Systems in Computer-Alded Design, Proceedings from IFIP WG 52 conference en Expent Systems in Conpuser-Aided Design, pages 423-431, Ansicotam. 1957, North-Holland.

[135) Jehn C. Tung and Larry J. Leifer. An Otoknational Methosology for Studying Group Design Activity. Reseanch in Enginecring Design, 2(4),200-219, 1991.

[136] M. R. Cutkosky and 1. M. Tenethaum. Providing Computational Support for Concurtent Engi-

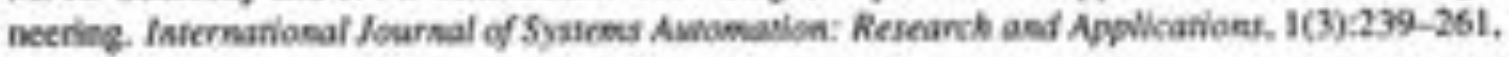
1991.

[137] Avron Barr and Edwand A. Feigentoum, edices. The Handbook of Artificlal hateWgence, Volume 1. HeurisTech Fosss. Standont. Culisomia, 1981.

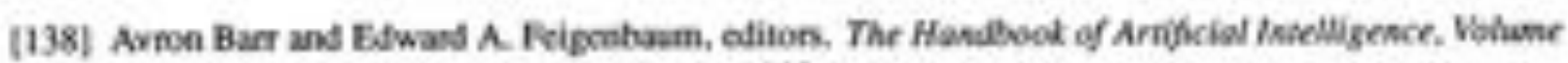
2. HeurisTech Poss, Stanfoud. Califomia. 1982.

[139] Paul R. Cohen and Edwand A. Feigenhaun, edinon. The Masdbook of Artifictal Inteiligence, Volwere 3. Heuristoch Fresk, Standoet. Califomia, 1982.

[140] Stcren Astley. The Banle wo Build Better Profucts. Mechasicaf Engineering- pages 34-38, Nov 1990.

[141] Sacven Ashley. DARPA Initistive in Concumen Enpincering. Mechanical Eegienerieg. 114(4)5457. Age 1992 . 
[142] Martin Cwiakala. Using Hypennedia Concepes to Entance CAD. Is G. L. Kinael and S. M. Rohde. ofinon. Proceedings of the 1990 ASME Coepusers is Eeginerieg Conferrnce, pages 131-137. ASME. American Society of Mechanical Engineers, 1990.

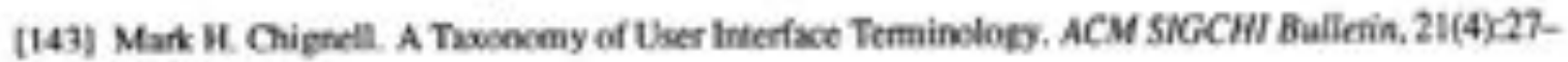
34, 1900 .

[144] Christoph Hubel and Dernd Sattex. Supporting Enginoering Applications by Nea Dera Dave Processing Concepts - An Experience Report. Exgievering witt Computers, 8(1):31-49, 1992.

[145] Katia P. Sycara and C. Micheal Lewik. Modeling Cosup Decision Making and Negotixion in Concurrent Prodea Design. Aerernarioeal Jownal of Systers Astomation: Research and Applications. 1(3):217-218, 1991.

1146) D. Sriran, R. Logcher, A. Wotg, and S. Ahmed. Compoter-Aided Cosperative Product Developmenk: A Cave Stufy, International Journal of Systems Automation: Research and Applications. $1(1) \times 89-112,1991$.

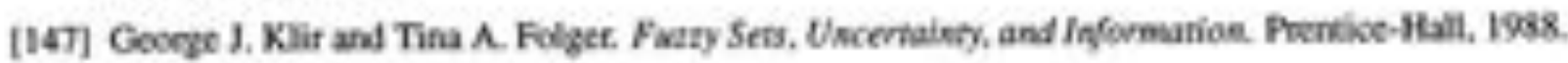

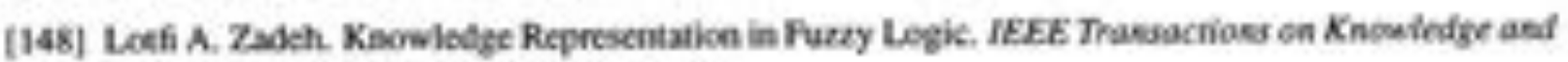
Desa Enginerering. I(1) 89 -99. Mar 1980.

[149] Dosglas R. Hofstadier. GSdel, Escher, Bach: Ae Eicrnal Golden Brald. Vintage Bocks, 1979.

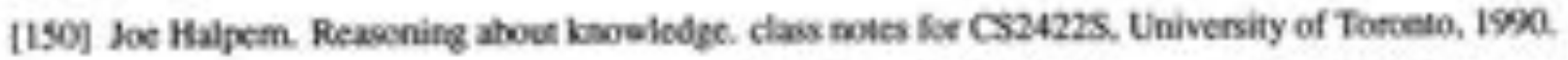

[151] Richard Suse and Gratam H. Powell. A Design Process Model for Conguier Inegrated Sinuctural Engineering: Desiga Faves and Tuks, Engincering wht Coepsiters, 7(3):145-160, 1991.

[152] Cive L. Dym and Ragmond E. Levilm. Toward the lentegnation of Knowlofge for Enpineering Modeling and Coniputation. Fingineerieg with Compaters, 7(4):209-224, 1991.

[153) Abraham A. Fracnkel, Yohoshus Bac-Hillel, and Azriel Levy. Foundatioss of Set Throry. NonthHolland, 1973.

[1S4] Mornis Kline. Mothereatics: The Less of Cernaiefy. Osfond Univeniry Press, 1950.

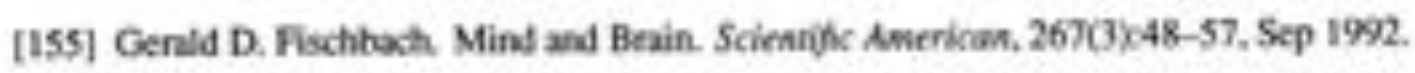

[156] Geoffrey E. Hinion. How Noural Netwods Leam from Experiknce. Scientife Awericae. 267\%3). 144-151, Sep 1992.

[157) Frascis Crick and Chrisiof Koch. The Problem of Cotsciousness. Scientjic American, 2673) 152$159, \operatorname{sep} 1992$

[158] John D. Wance and James R. Rinderle. A Method to Idetify Refomnelanions of Mechatical Paranctric Conurains to Eshance Design. In James R. Rinderle and David G. Uliman. efitors. Desige Theary and Merhodology, ASMEE Devign Auncenation Confenenoes, pages $77-84$, New York, 1990, AS34E. 
[159] Bjame Strovatup. What is Ceject-Orientod Programaing? IEEE Sofoware, pages 10-20, May 1988.

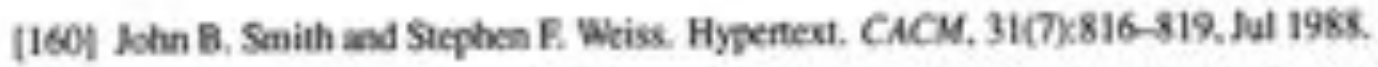

[161] J. Walt and 1, S. Cotion. A Franework for Featuro Based Kegesentalign of the Design Process. Engineerikg with Compaters, 6/3):185-192. 1900 .

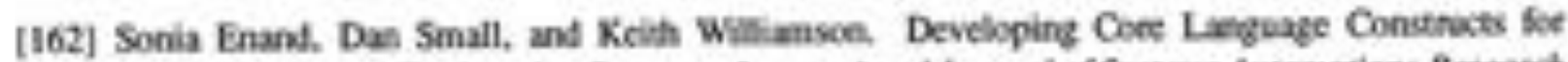

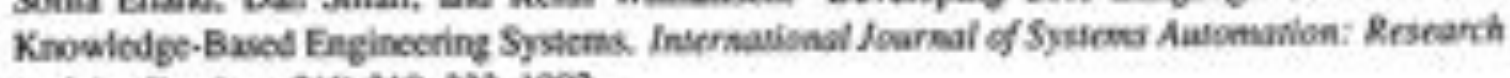
and Agplications, 2(4):319-533, 1992.

[169] K. O. Swifl. Knowindge-Azsed Design for Masefachave. Prentice-Hall, Ine., 1987.

[164] Peter Whener. Concepts and Paradigns of Objod-Oriented Programming ACM OOPS Messenger. pages 8-87, Jun 1990

[165] J. M. Spivey. Undersanding Z; A Sprcifcarion Langage aed its Formal Smannics. Cambrige Univessity Press, toss.

[166] wall Durant. The Snory of Fhilosophy, Pucket Books, 1961.

[167] Kik Martini and Grakam H. Rowell, Govenetric Modcling Requirements for Structural Design. Enginerige with Conpaicrs, 6:2793-102, 1990.

[168] Jintac Lee and Thoenas W. Malone. Partially Shutod Views: A Schcine for Communicaring among Grosps tha Use Different Type Hieractich. ACM Thuesactions os foformation Sysarms, 81):1-26. Ias 1990

[169] Sieven J. Fenves, persceal coenemunication, 192.

[170] Jobn Bell and Moshe Machover. A Course is Matbmanicaf Logic. Elsevier Science Publishers. Amstendam, 1977 .

[171] Micheal f. Whony. Begred Computer Graptics and CADVAM. In Tesiyase L. Kunii, editof,

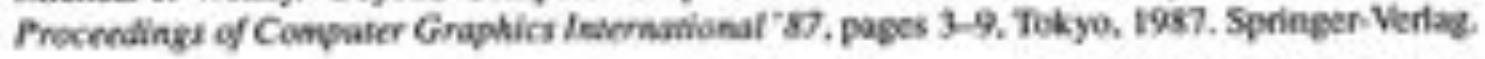

[172| Siefan Dessloch. Curisupph Hothel, Nelson Menbonca Manos, and Bemd Sutter. Handling Func: tional Constnints of Tectnical Modeling Systens in a KBMeS Envinemene, Ieternational Journal of Systems Aarowation: Rereanch and Applicanlons, I(4)347-367, 1991.

[173] P. Bemws and Z. Letrap, Intelligent Systems Intervenectionc. What Shosld Come After Open Systems Intercotanectios? Is P. J. W. ien Hapen and Tetoso Tomilyamz, editors, Intelikeses CAD Sysnens $f$ (Theoretical and Meshodalogical Aspects). Eumerapticseminar Series. pages 44-55. Berlin, 1957. Springer-Verlag.

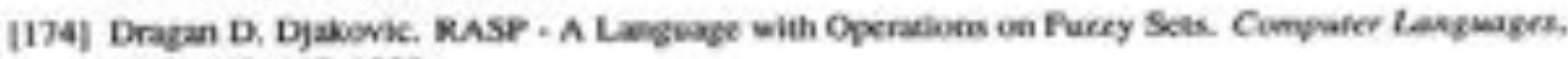
$13(3): 143-147.1988$.

[175] Allen C. Want. Some Language-Based Approaches to Concurnent Engineering- International Sournot of Sysienu Aatomatian: Research and Applicarioes. 2(4)-335-351, 1992. 


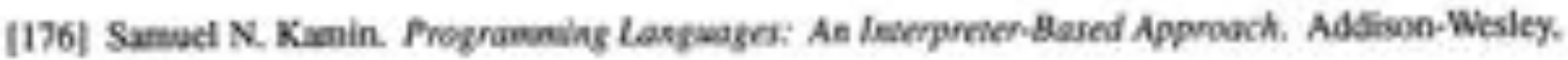
1990

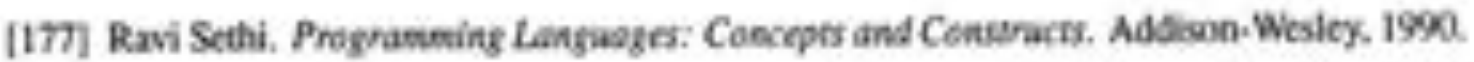

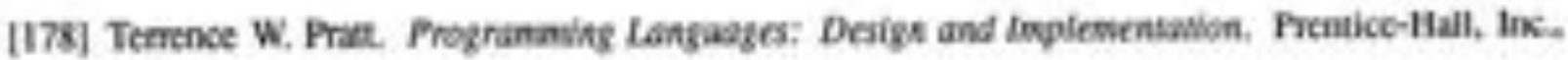
1975.

[179] Robert R. Kessler. LSP, Objects and Symbolic Pregramming- Soot, Foneman and Comapany. $198 s$.

[130| Anthory J. Field and Peate G. Hamison. Fuecwanal Programunieg. Intemational Compuier Science Series. AdGinon-Wesley, 1958.

[181] Joen W, Baugh Jf, and Daniel R. Relok. Applications ef Coarse-Grained Dataflow in Compotalional Mechantes, Engineerieg wim Conpaters, N1);13-30, 1992.

[182] David A. Walt. Prognawening Langage Syntar and Semantics. Prentice Hall Inbemational Series in Oomputer Sciesce. Prentice Hall Inc. 1991.

[183] Revised? Report en the Algonithic Languge Scheme. ACM Sigplas Nowers, 21(12), Dec 1986.

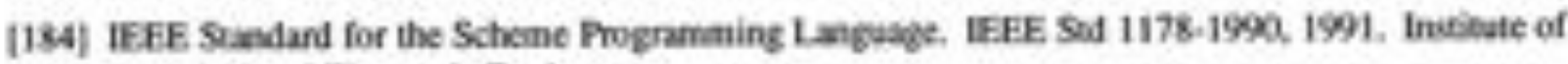
Electrical and Eloctronic Engincth.

[Iss] Kent Dybwie. The Srbome Prognanuing Language. Prentice-Hall, Ine. 1957.

[186] Oliver Lasmann and Carsten Boman. Elk: The Exıersion Language Kit. working paper, incleded with source, 1972 .

[187] Guy Argo, Nhn Haghes, Philly Trinder, Jon Faitbim, and Jehn Lanchbury. Inplementieg Fianctionat Dafabases, chapeer 10, pages 165-176. ACM Press Fonetier Series. Addicon-Wesley. 1990

[tiks] Ovear Nierstrav. A Survey of Object-Oriested Casceprs, chepter 1. pages 3-21. ACM Press Fromtier Series. AdSison-Wesley, 1959.

[189] Kenneth Kahn. Ene Dean Tribele, Mark \&. Milter and Dariel Q. Botrow, Vaican: Logical Cancarrese Object, pages 75-112. Compoter Sysems Series. The MrT Phess. 1987.

[190| Gio Wioderhold. Vices, Otjocts, and Darahases. IEEE Computer, 19612)-37-44, Dee 1956.

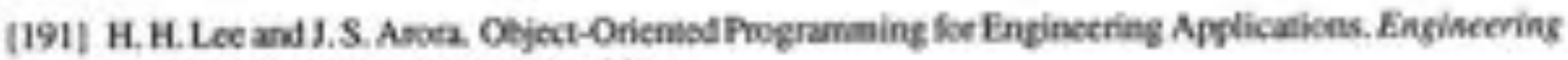
wibl Computers, $7(4)$ 2225-235, 1991.

[192] Bruce W. R. Foefe, Ricanto O. Fosch, and Siegfinod R. Stiemet, Object-Oriented Finite Element Anatyis. Compuners and Stroctures, 34(3):355-374, 1990.

[193] Gail M. Shaw and Starley B. Zdoeik. A Query Algotra for Cevioct-Orienied Datahuses. Tochnical Report CS-s9-19, Department of Creiputer Science, Brown Lniversity, Powidence, Rhode kland. Mar 1959. 
[194] MEcheal Kifer, Georg Laven, and lanes Wu. Logical Foundations of Object-Oriented and FrameBased Languages. Tochsical Repon 9014 (2nd eevision). Depantacnt of Compuler Science, SUNY. Siony Bscok, NY. Aug 1990

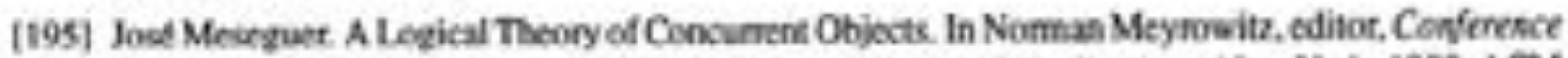

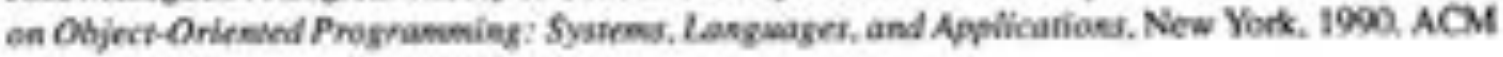
Powss.

[196] Varbus authors. XUSPARCDBSSC/OODBTO Final Report. Tecturical repert, Accredited Standards Cenminse $\mathrm{X} 3,1991$.

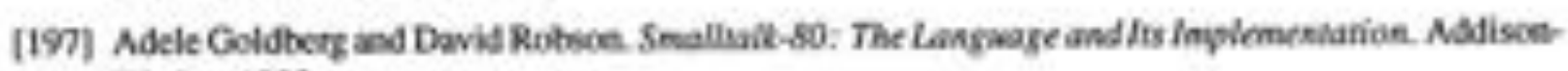
Wesley, 1983.

[198] Bjanne Sursustrup A C++ Tutcrial, Compuser Science Tochnical Reports 113, ATAT Bell Labs. Murrag Hill, NU.Sep 1934.

[199] Ralph E. Jotnoen and Jonathan M. Zwcic. Delegation in C4-4. Joareal of Object-Orienied Pregraniming. 4(7) 31 1-44, 1991.

1200| Various Authes. The SELF Papers. Tothnical Reped CIS 209, Sundiod Univensity. Stanfond, CA. 1991.

[201] Wolfgang Kecuener and Malcolm Staimand. C-Flwose: A Scheme-Bacd Flavour System with Coroutines and its Applications to the Design of Object-Onerned Simulakion Softwart. Computer Languages, 1S(4).225 -249 , 1990.

[202] Sephen Slade. The T Prognamoing Langage: a dialect of LSP. Prontice-Hall, Inc., 1987.

[203] Josept A. Goguen and lose Meseguer. Unifying Functisnal, Object-Oriented and Relawanal Progranunieg with Logkal Semanticx. pages 417-477, Couputer Systems Series. The MrT Press. 1987.

[204] Christian Queiruxec. Menoor: A Snatl, Efifcient and Enhanced Otyect System, unpublished book chapker, July 1992.

[205] Sho-Huan Simon Tung. Merging Leikractier, Modular and Object-Oviented Prognamieg. PhD thesis, Deportment of Conpuner Science, Indixna Univenitys 1992.

[206] Kamran Panaye, Mark Chignell, Setrag Koohafian, and Hamy Wong. IateWrent Danahase: Object-Ovienied, Deductive Nopermedlia Testnologirs. Johe Wiley and Soes, Inc. 1959.

1207) Noman Adans and Jonxhan Rees. Object-Oriendod Poogramning in Scheme. Le Jerome Chailloux, editor, Proceedings of ste 1958 ACM Covfenese on LSP and Functional Pregnaminieg, papes 277-288, New York, 1943. ACM.

[208] UAlay \&. Reddy, Objects as Closures: Abstract Sonantics of Oeject Oniented Languages. In Jerome

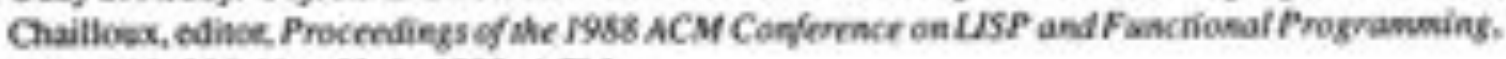
pages 289-297, New Yod, 1985. MCS. 
[209] Leca Castelli. A Semaatics of Mwhiple fnterinesce, pages 99-83. The Morgan Kaufnarn Series in Data Management Sysiems. Morgas Kaufmasn, 1990.

[210] Luca Castelli and Peace Wegner. On Undentaniling Tyses, Data Abstraction, and Polymorphion. ACM Compunine Sarveys. 17(4):471-522, 1985.

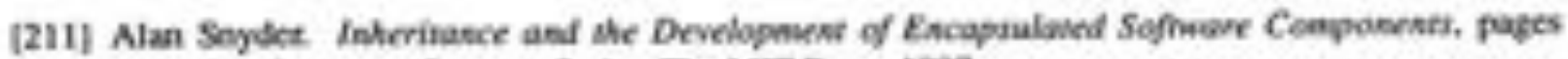
165-188. Coenpoter Sysiems Series, The MIT Press, 1987.

[212] Donthim Zeid. CADiCAM: Theory asd Pracrice. MoOraw-Hill, Ine. 1991.

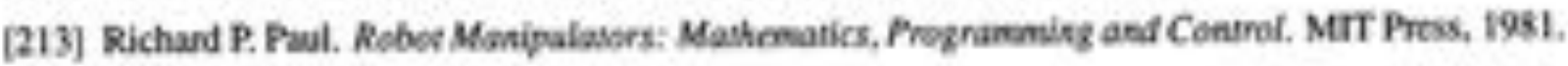

[214] William C. Reynobds and Hency C. Perkins, Engineering Therwodynamiks. MoGriw-Hill. 1977.

[215] Willian H. Beyer, edime. CRC Snasdand Meshomatical Tables, CRC Press, Inc, 27 editicn, 1954.

1216] Brent Hallpem and Van Nizuyen. A Moddfor Object-Based Inheriansce, pages 147-164. Conpuler Sydems Series. The MrT Press, 1987.

[217] Roman Cunis. A Pakage for Havdling Units of Meaver in Lisp. ACM LSSP Pointers, 5(2):21-25. 1992 .

[218] Bdwand Scione. Cbjoct Specialization. ACN Thanacrioss en Lfformation Sysreme, 7(2):103-12. Ape 1989.

[219] Shinn-Der Lee and Daeiel P. Friedman. Frst-Class Esitents. Technical Report 350, Coepuler Science Department, Indiana Univensity, Bocenington. Indiana, Mar 1992.

[220] MEched Puttre. Virtual Prototypes Mowe Alengside Their Physical Counterparts. Mnchanical Etginering, pages $59-61$. Aug 1992.

[221] H. N. An-Nastif and G. H. Powell. An Otject-Oricniod Alorithe for Avbomaned Modeling of Frame Stroctures: Stiffness Modeling, Esqieering wiat Cemputrrs. 7(2):121-128, 199L.

(22) Hamideh Afamanesh. The 3Dis: An Exwetsible Oeject-Oriented Informatice Maragemene En. vircemene. ACM Thansactians on Irformatan Sysirms. 7(4):339-377, Oct 1959.

[223] Graly Booch. Object Ovienend Design wiah Apowcariows. Benjastin/Cummings Publishing Counpany, Inc., 1991.

[224] Seve Foed, Jotn Joseph, David E. Langworthy, Davis F. Lively, Girksh Pathak, Edwad R. Perex. Roben W, Peterscn, Dian M. Spancin, Satish M. Thune, David L. Wells, and Sxejive Agarwala. Zeitgeis: Database Sappon for Otjoct-Orientod Progranming, In K. R. Diturich, editor, Advances is Object-Orienred Dasabases (Procendings of 2 nd Insernational Worketop on Object-Orienind

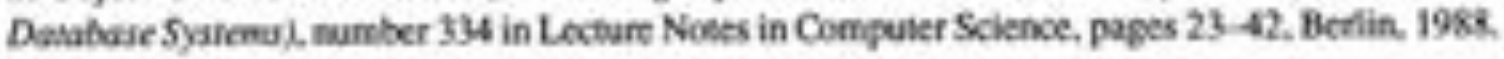
Springer-Verlag.

[225] Setrag Khoshafian and Dan Frak. Implomentaken Techniques foe Object Oriented Databases. In

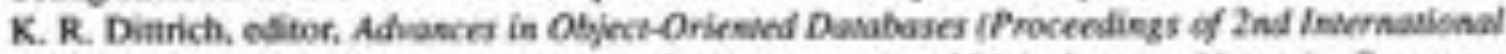

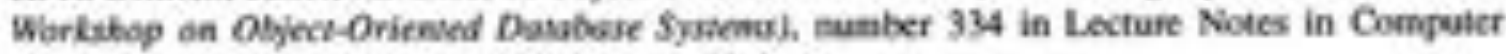
Science. payes 60-50, Berlin, 1948, Springer-Vertaz. 